\title{
Analytical results and sample locality map of stream-sediment, heavy-mineral-concentrate, soil, and rock samples from the Pecos Wilderness, Santa Fe, San Miguel, Mora, Rio Arriba, and Taos Counties, New Mexico
}

By

M. S. Erickson, S. J. Sutley, and R. H. Moench

Open-File Report $86-171$

This report is preliminary and has not been reviewed for conformity with U.S. Geological Survey editorial standards and stratigraphic nomenclature. Any use of trade names is for descriptive purposes only and does not imply endorsement by the USGS. 


\section{CONTENTS}

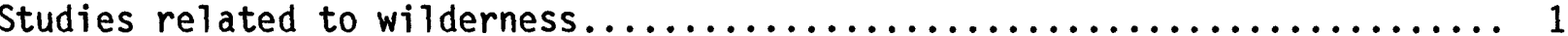

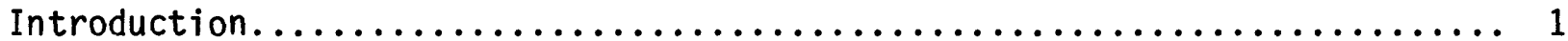

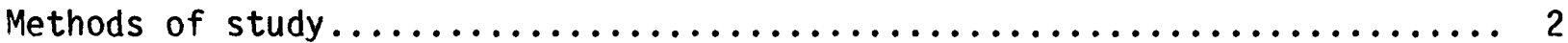

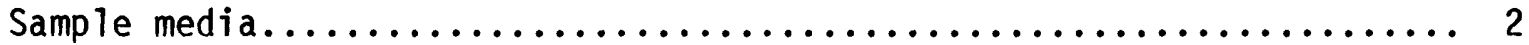

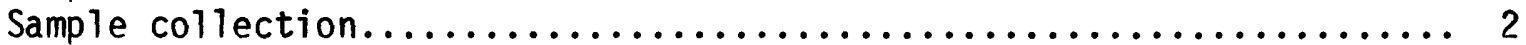

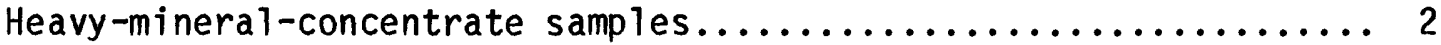

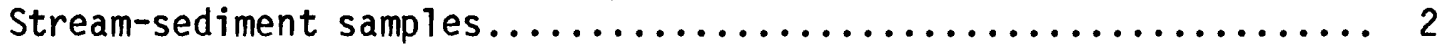

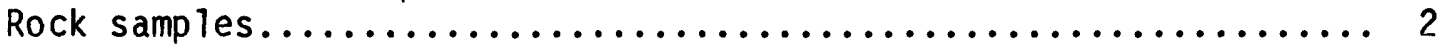

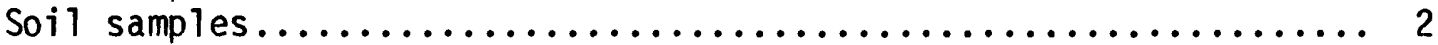

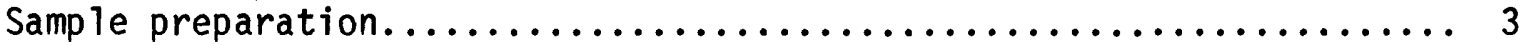

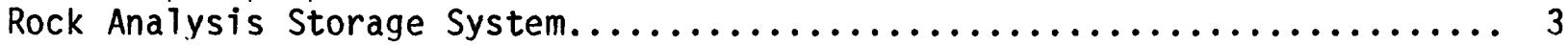

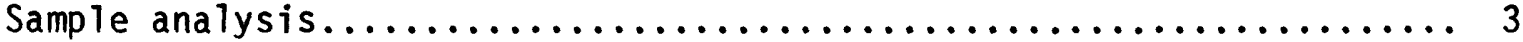

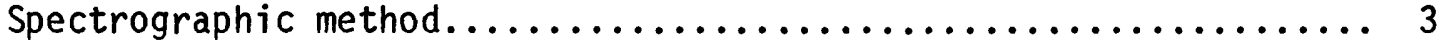

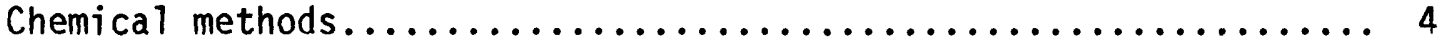

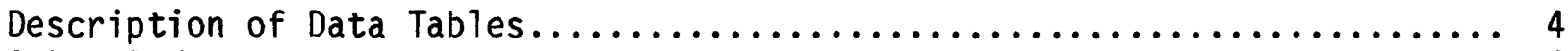

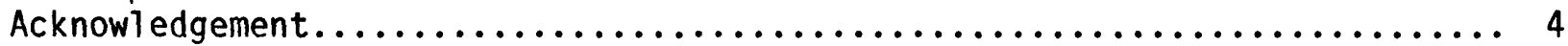

References Cited................................... 4

List of Geochemical Maps of the Pecos Wilderness and Adjacent Areas....... 6

\section{ILLUSTRATIONS}

PLATE 1. Localities of stream-sediment, heavy-mineral-concentrate, soil, and rock samples from the Pecos Wilderness, Santa Fe,

San Migue1, Mora, Rio Arriba, and Taos Counties, New

Mexico.

in pocket

\section{TABLES}

TABLE 1. Limits of determination for spectrographic analysis of rocks, soils and stream sediments........................ 7

TABLE 2. Chemical methods used.......................... 8

TABLE 3. Analyses of NM1-concentrate samples.................. 9

TABLE 4. Anatyses of M1-concentrate samples.................... 48

TABLE 5. Analyses of M.5-concentrate samples.................. 87

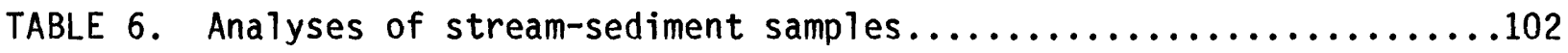

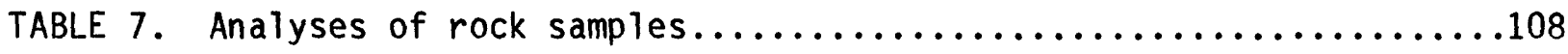

TABLE 8. Analyses of soil samples................................. 


\section{STUDIES RELATED TO WILDERNESS}

The Wilderness act (Public Law 88-577, September 3, 1964) and related acts require the U.S. Geological Survey and the U.S. Bureau of Mines to survey certain areas on Federal Lands to determine their mineral resource potential. Results must be made available to the public and be submitted to the President and the Congress. This report presents the results of a geochemical survey of the Pecos Wilderness and (or) Roadless Area in the Santa $\mathrm{Fe}$ and Carson National Forests, Santa Fe, San Miguel, Mora, Rio Arriba, and Taos Counties, New Mexico. The area was established as a wilderness by Public Law New Mexico Wilderness Act (1980). The Pecos Roadless Area was classified as a further planning area or proposed wilderness during the Second Roadless Area Review and Evaluation (RARE II) by the U.S. Forest Service, January 1979.

\section{INTRODUCTION}

In 1977 and 1979-80 the U.S. Geological Survey conducted a reconnaissance geochemical survey of the Pecos Wilderness, Santa Fe, San Miguel, Mora, Rio Arriba, and Taos Counties, New Mexico.

The Pecos Wilderness comprises about $350 \mathrm{mi}^{2}$ in northern New Mexico, and lies at the southern end of the Sangre de Cristo Range, northeast of Sante Fe, New Mexico. Access to the study area is provided by several roads that lead from Interstate 25 on the east and south, U.S. 285 on the west, and New Megico routes 68 and 3 on the north. This survey covers an area of about $500 \mathrm{mi}^{2}$, which includes the Pecos Wilderness and an additional 150 square miles adjacent to the wilderness.

The study area is underlain by igneous and metamorphic rocks of Precambrian age that are partly covered east of the Pecos-Picuris fault by subhorizontal sedimentary strata of Mississippian, Pennsylvanian, and Permian age. The Pecos-Picuris fault is a major north-trending strike-slip fault of Precambrian ancestry that was reactivated as a dip-slip fault in the Pennsylvanian and again in Late Cretaceous and Early Tertiary time (Moench and others, in press). It divides the Precambrian rocks of the study area into two separate metamorphic-plutonic terranes: (1) a western batholithic terrane containing parts of two major granitic batholiths and septa of high rank stratified metamorphic rocks; and (2) an eastern terrane composed mainly of stratified high rank metamorphic rocks intruded by smaller granitic plutons. By far the most important mineral resources of the study area are associated with the Precambrian rocks. The geology of the area is described by Moench, Grambling, and Robertson (in press); mineral resources are discussed by Moench and Lane (in press); and geochemical maps are furnished by Moench, Sutley, and Erickson (in press).

The study area is at the southern end of the Sangre de Cristo Range. It is characterized by an axial line of alpine peaks that rise to more than 13,000 feet, flanked on the west and north by heavily wooded ridges and canyons that drain to the Rio Grande Valley, and on the southeast by a high dissected plateau of meadows and forest. The plateau is dissected by deep canyons of the Pecos River and its tributaries, and is bounded on the east by a scarp of about 3,000 feet. Partly forested ranchland lies below the base of the scarp to the east, and beyond that is prairie of the Great Plains. 


\section{METHODS OF STUDY}

\section{Sample Media}

Analyses of the stream-sediment samples represent the chemistry of the rock material eroded from the drainage basin upstream from each sample site. Such information is useful in identifying those basins which contain concentrations of elements that may be related to mineral deposits. Heavymineral-concentrate samples provide information about the chemistry of certain minerals in rock material eroded from the drainage basin upstream from each sample site. The selective concentration of minerals, many of which may be ore-related, permits determination of some elements that are not easily detected in stream-sediment samples.

Analyses of altered or mineralized rocks, where present, may provide useful geochemical information about the major- and trace-element assemblages associated with a mineralizing system. Analyses of soils provide information on the concentration of metals in the bedrock below the soils that were sampled.

\section{Sample Collection}

Samples were collected at 608 sites. At 48 of those sites, both a stream-sediment sample and a heavy-mineral-concentrate sample were collected, and at 554 sites a heavy-mineral concentrate was collected. Rock samples were collected at 12 sites, and soil samples were collected at 43 sites in selected areas. Sampling density was about 1 sample site per $0.9 \mathrm{mi}^{2}$ for the heavymineral concentrates.

\section{Heavy-mineral-concentrate samples}

The heavy-mineral-concentrate samples were collected by panning of active alluvium, primarily from first-order (unbranched) and second-order (below the junction of two first-order) streams as shown on USGS topographic maps $(1: 62,500)$. At each locality, sand and gravel coarser than $2 \mathrm{~mm}$ was discarded and the finer fraction was panned until most of the quartz, feldspar, organic material, and clay-sized material was removed.

\section{Stream-sediment samples}

The stream-sediment samples were collected from the same active alluvium as the heavy-mineral-concentrate samples. At each locality one sample was obtained from the finest-grained material available; where possible, organic material was avoided.

\section{Rock samples}

Rock samples were collected from outcrops or exposures in the vicinity of the plotted site location. Samples were collected only from altered and/or mineralized rocks.

\section{Soil samples}

The soil samples were collected from zone B in the weathering profile (just below the organic-rich surface zone). Of the 42 samples, 37 were 
collected along two traverses in a small area of suspected mineralized rock, and five were collected on the traces of two major faults.

\section{Sample Preparation}

The stream-sediment samples were air dried, then sieved using 80 mesh $(0.17 \mathrm{~mm})$ stainless steel sieves. The portion of the sediment passing through the sieve was saved for analysis.

Each heavy-mineral-concentrate sample was prepared as follows: After drying, the light minerals (mainly quartz and feldspar) were removed by flotation in bromoform and discarded. Magnetite was then removed from the heavy fraction using a hand magnet. The nonmagnetic-paramagnetic fraction was then run through a Frantz Isodynamic magnetic separator at 0.2 amperes (side tilt $15^{\circ}$, forward tilt $25^{\circ}$ ) to remove all remaining magnetite, ilmenite, and pyrrhotite. The nonmagnetic fraction was then rerun at 0.5 amperes, and the magnetic fraction was stored for possible analysis. The nonmagnetic fraction was rerun at 1 ampere, and the resulting magnetic and nonmagnetic fractions were used for the geochemical survey.

Rock samples were crushed and then pulverized to minus $0.15 \mathrm{~mm}$ with ceramic plates.

\section{ROCK ANALYSIS STORAGE SYSTEM}

Upon completion of all analytical work, the analytical results were entered into a computer-based file called Rock Analysis Storage System (RASS). This data base contains both descriptive geological information and analytical data. Any or all of this information may be retrieved and converted to a binary form (STATPAC) for computerized statistical analysis or publication (VanTrump and Miesch, 1976).

\section{Sample Analysis}

\section{Spectrographic method}

We analyzed the stream-sediment, heavy-mineral-concentrate, rock, and soil samples for 31 elements using a semiquantitative, direct-current arc emission spectrographic method (Grimes and Marranzino, 1968). The elements analyzed and their lower limits of determination are listed in Table 1. Spectrographic results were obtained by visual comparison of spectra derived from the sample against spectra obtained from standards made from pure oxides and carbonates. Standard concentrations are geometrically spaced over any given order of magnitude of concentration as follows: $100,50,20,10$, and so forth. Samples whose concentrations are estimated to fall between those values are assigned values of $70,30,15$, and so forth. The precision of the analytical method is approximately plus or minus one reporting interval at the 83 percent confidence level and plus or minus two reporting intervals at the 96 percent confidence level (Motooka and Grimes, 1976). Values determined for the major elements (iron, magnesium, calcium, and titanium) are given in weight percent; all others are given in parts per million (micrograms/gram). Analytical data for samples from the Pecos Wilderness are listed in Tables 3-8. 


\section{Chemical methods}

Other methods of analysis used on samples from the Pecos Wilderness are summarized in Table 2.

Analytical results for stream-sediment, rock, and soil samples are listed in Tables 6, 7, and 8, respectively. No wet chemistry was run on any of the three types of concentrates.

\section{DESCRIPTION OF DATA TABLES}

Tables 3-8 list the analyses for the samples of the nonmagnetic fraction at 1 amp, the magnetic fraction at $1 \mathrm{amp}$, and the magnetic fraction at 0.5 amp, hereafter referred to as NM1, M1, and M.5 heavy-mineral concentrates, stream sediments, rocks, and soils, respectively. For the tables, the data are arranged so that column 1 contains the USGS-assigned sample numbers. These numbers correspond to the numbers shown on the site location maps (plate 1). Columns in which the element headings show the letter "s" below the element symbol are emission spectrographic analyses; "aa" indicates atomic absorption analyses. A letter " $N$ " in the tables indicates that a given element was looked for but not detected at the lower limit of determination shown for that element in Table 1. If an element was observed but was below the lowest reporting value, a "less than" symbol (<) was entered in the tables in front of the lower limit of determination. If an element was observed but was above the highest reporting value, a "greater than" symbol ( $>$ ) was entered in the tables in front of the upper limit of determination. If an element was not looked for in a sample, two dashes (-) are entered in Tables 3-8 in place of an analytical value. Because of the formatting used in the computer program that produced Tables 3-8, some of the elements listed in these tables ( $\mathrm{Fe}, \mathrm{Mg}, \mathrm{Ca}, \mathrm{Ti}, \mathrm{Ag}$, and $\mathrm{Be}$ ) carry one or more nonsignificant digits to the right of the significant digits. The analysts did not determine these elements to the accuracy suggested by the extra zeros.

\section{ACKNOWLEDGEMENT}

The authors wish to thank Gary A. Nowlan and Betty M. Adrian for the computer work and data retrievals done on this study.

\section{REFERENCES CITED}

Grimes, D. J., and Marranzino, A. P., 1968, Direct-current arc and alternating-current spark emission spectrographic field methods for the semiquantitative analysis of geologic materials: U.S. Geological Survey Circular 591, $6 \mathrm{p}$.

Moench, R. H., Grambling, J. A., and Robertson, J. M., 198,, Geologic map of the Pecos Wilderness, Santa Fe, San Miguel, Mora, Rio Arriba, and Taos Counties, New Mexico: U.S. Geological Survey Miscellaneous Field Studies Map MF- $-B$, scale 1:48,000.

Moench, R. H., and Lane, M. E., 198, Mineral resource potential of the Pecos Wilderness, Santa Fe, San Miguel, Mora, Rio Arriba, and Taos Counties, New Mexico: U.S. Geological Survey Miscellaneous Field Studies Map MF- $\quad-A$, scale $1: 48,000$. 
Moench, R. H., Sutley, S. J., and Erickson, M. S., 198, Geochemical maps of the Pecos Wilderness and adjacent areas, Santa Fe, San Miguel, Mora, Rio Arriba, and Taos Counties, New Mexico: U.S. Geological Survey Miscellaneous Field Studies Map MF- , scale 1:96,000, 1:48,000, and $1: 24,000$.

Motooka, J. M., and Grimes, D. J., 1976, Analytical precision of one-sixth order semiquantitative spectrographic analyses: U.S. Geological Survey Circular 738, 25 p.

Thompson, C. E., Nakagawa, H. M., and Van Sickle, G. H., 1968, Rapid analysis for gold in geologic materials, in Geological Survey research 1968: U.S. Geological Survey Professional Paper 600-B, P. B130-B132.

VanTrump, George, Jr., and Miesch, A. T., 1976, The U.S. Geological Survey RASS-STATPAC system for management and statistical reduction of geochemical data: Computers and Geosciences, v. 3, p. 475-488.

Ward, F. N., Lakin, H. W., Canney, F. C., and others, 1963, Analytical methods used in geochemical exploration by the U.S. Geological Survey: U.S. Geological Survey Bulletin 1152, $100 \mathrm{p}$.

Ward, F. N., Nakagawa, H. M., Harms, T. F., and Van Sickle, G. H., 1969, Atomic-absorption methods useful in geochemical exploration: U.S. Geological Survey Bulletin 1289, $45 \mathrm{p}$. 
GEOCHEMICAL MAPS OF THE PECOS WILDERNESS AND ADJACENT AREAS, SANTA FE, SAN MIGUEL, MORA, RIO ARRIBA, AND TAOS COUNTIES, NEW MEXICO

By Robert H. Moench, Stephen J. Sutley, and Marjorie S. Erickson

Map A--Simplified bedrock geologic map showing locations of geochemical samples, and locations of heavy-mineral concentrates from stream sediments that contain exceptionally high abundances of indicated elements (parts per million), 1:48,000

Map B--Tungsten and tin in heavy-mineral concentrates from stream sediments (parts per million), 1:96,000

Map C--Molybdenum in heavy-mineral concentrates from stream sediments (parts per million), 1:96,000

Map D--Copper in heavy-mineral concentrates from stream sediments (parts per million), 1:96,000, and copper in soils (B zone) in Doctor Creek area (parts per million), 1:24,000

Map E--Zinc, niobium, antimony, and beryllium in heavy-mineral concentrates from stream sediments (parts per million), and radon in springs and streams ( $p$ icocuries per liter), 1:96,000

Map F--Lead in heavy-mineral concentrates from stream sediments (parts per million), and radon in spring and stream water (picocuries per liter), $1: 96,000$

Map G--Bismuth, silver, and gold in heavy-mineral concentrates from stream sediments (parts per million), 1:96,000 
TABLE 1.--Limits of determination for the spectrographic analysis of rocks, soils, and stream sediments, based on a $10-\mathrm{mg}$ sample

[The spectrographic limits of determination for heavy-mineral-concentrate samples are based on a 5-mg sample, and are therefore two reporting intervals higher than the limits given for rocks and stream sediments.]

Elements Lower determination limit Upper determination limit

\section{Percent}

\begin{tabular}{lcc}
\hline Iron (Fe) & 0.05 & 20 \\
Magnesium (Mg) & .02 & 10 \\
Calcium (Ca) & .05 & 20 \\
Titanium (Ti) & .002 & 1 \\
\hline
\end{tabular}

Parts per million

$\begin{array}{lcr}\text { Manganese (Mn) } & 10 & 5,000 \\ \text { Silver (Ag) } & 0.5 & 5,000 \\ \text { Arsenic (As) } & 200 & 10,000 \\ \text { Gold (Au) } & 10 & 500 \\ \text { Boron (B) } & 10 & 2,000 \\ \text { Barium (Ba) } & 20 & 5,000 \\ \text { Beryllium (Be) } & 1 & 1,000 \\ \text { Bismuth (Bi) } & 10 & 1,000 \\ \text { Cadmium (Cd) } & 20 & 500 \\ \text { Cobalt (Co) } & 5 & 2,000 \\ \text { Chromium (Cr) } & 10 & 5,000 \\ \text { Copper (Cu) } & 5 & 20,000 \\ \text { Lanthanum (La) } & 20 & 1,000 \\ \text { Molybdenum (Mo) } & 5 & 2,000 \\ \text { Niobium (Nb) } & 20 & 2,000 \\ \text { Nickel (Ni) } & 5 & 5,000 \\ \text { Lead (Pb) } & 10 & 20,000 \\ \text { Antimony (Sb) } & 100 & 10,000 \\ \text { Scandium (Sc) } & 5 & 100 \\ \text { Tin (Sn) } & 10 & 1,000 \\ \text { Strontium (Sr) } & 100 & 5,000 \\ \text { Vanadium (V) } & 10 & 10,000 \\ \text { Tungsten (W) } & 50 & 10,000 \\ \text { Yttrium (Y) } & 10 & 2,000 \\ \text { Zinc (Zn) } & 200 & 10,000 \\ \text { Zirconium (Zr) } & 1,000 \\ \text { Thorium (Th) } & 10 & 2,000 \\ \text { Thorium } & 100 & \end{array}$


Table 2.--Chemical methods used

$[A A=$ atomic absorption; $S=$ spectrophotometry; $C X=c o l o r i m e t r i c(C U)$ : and cold extractable (HM)]

$\begin{array}{lccc}\begin{array}{l}\text { Element or } \\ \text { constituent } \\ \text { determined }\end{array} & \text { Method } \begin{array}{r}\text { Determination limit } \\ \text { (micrograms/ } \\ \text { gram or ppm) }\end{array} & \begin{array}{c}\text { Reference } \\ \text { Gold (Au) }\end{array} \\ \text { Copper (Cu) } & \text { Colorimetric } & 10 & \begin{array}{c}\text { Thompson and } \\ \text { others, } 1968\end{array} \\ \text { Heavy metals (HM) } & \text { Cold extractable } & 1 & \begin{array}{c}\text { Ward and } \\ \text { others, } 1969 \\ \text { Ward and } \\ \text { others, } 1963\end{array}\end{array}$




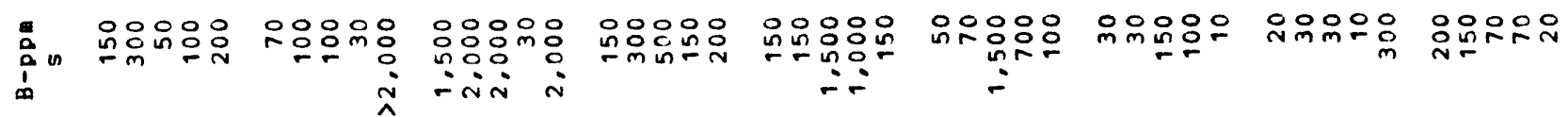

$z z z z=z z$

$z z z z z \quad z z z z z \quad z z z z z$

$z z z z=$

$z z z z=$

$z z z z z \quad z z z z$

a

$z z z z z=z z z$

$z z z z z$

$z z z z$

$z z z z$

$z z z z$

$z z z$

$z z z z$

$z z z z$

is

ind

洂

$a_{0}^{5}$

$z x z=2 x y z$

$z z z z$

$z z z z$

$z z z z$

$z z z z=z z z z$

$z z=\stackrel{0}{\text { in } z}$

$z=2 z=$

空

웃윰운용

$00: 00$

00000

00000

00000

웅요

용ㅇㅇㅇ

응유융유

옹응웅 in

0.000

00000

0000000000

00000

0.090

$\because \because \because \because \because$

$\because \because \div \div \div$

00000

$\sum_{-1}^{0}$

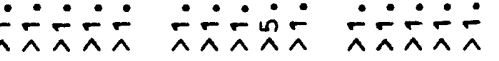

촛ำ

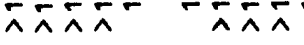

ทงทง

范

은웅우눙

우융ㅇㅇ은

드웅요

욲용능ํํ

으유윰유

웅유웅요

웅ํㄴ는

ㅇํㅇㅇㅛ

운은우요응

$\stackrel{i}{u}_{\substack{0 \\ \vdots}}$

ํํํํํํํำ

욲윢유웅

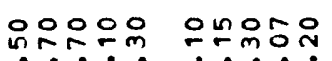

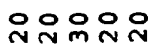

눙유유ํำ

윢융으옹

동융우융요

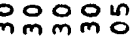

$=$

co

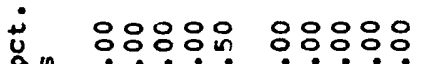

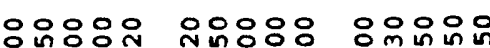

00000

$0 ㅇ ㅇ ㅇ$ $\because \dot{\sim} \dot{n}$

$\dot{m} \dot{\mathrm{N}} \dot{\circ} \therefore \dot{\sim} \dot{m}$

$\dot{m} \dot{\mathrm{N}} \dot{-}$

$\because \dot{n} \dot{\pi}$

$\dot{m} \div \dot{\sim} \div$

$\because \because \because-$

뚜둥

응요융응

옹ํㅇ

i

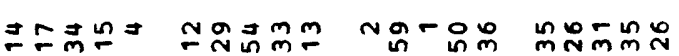

กูกูกูกร

gaming

궁ํ요

minim:-

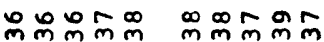

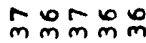

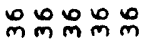

品品品品品

กํำm

옹오응

픔을

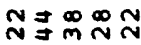

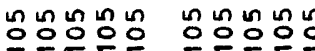

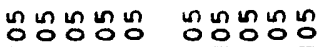

ํํㅇํํㅇํㅇㅇㅇㅇ응

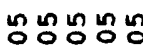

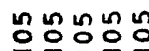

오욱영여

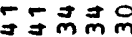

오

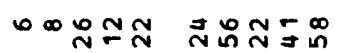

DNOLD

ํㅗํํํำ

พกิกับ

กmNma

ำกำ

ํㅗㅇํํㅇํㅇㅇํㅇํㅇㅇ

능ํํㅇํㅇํㅇㅇำ

ตำกำ

只昌触色

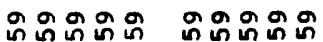

- O00

- $m$ 용ํํ

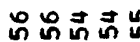

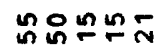

두끙ㅇㅇㅡ

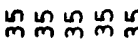

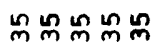

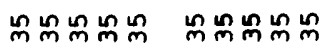

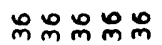

品品而出品

邑品品品品

ถู雚距的

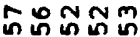

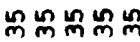

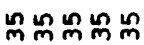

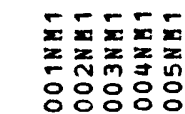

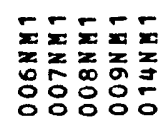

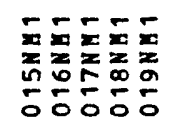

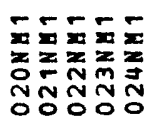

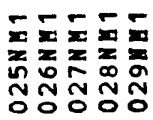

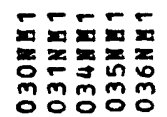

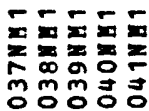

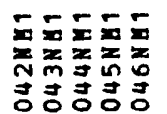

$\sum \bar{x} \bar{x}$

중ㅊㅇㅇ

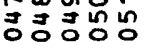




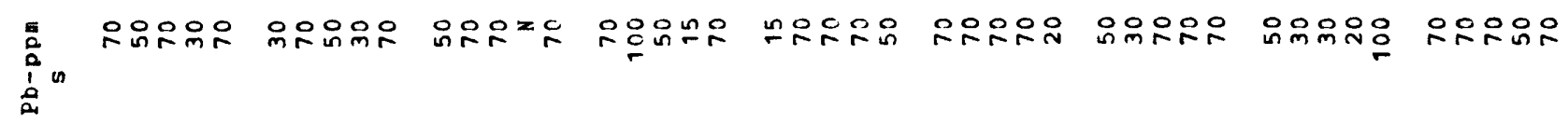

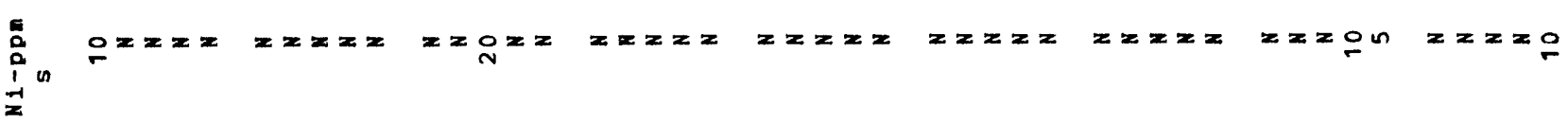

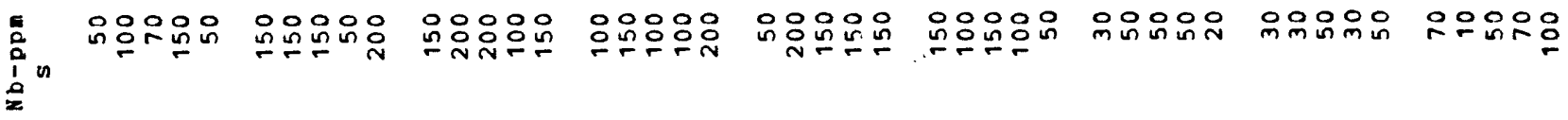

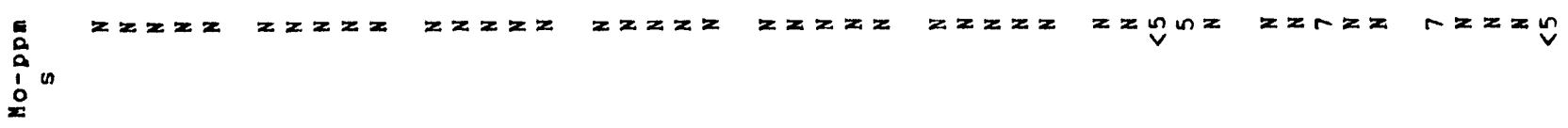

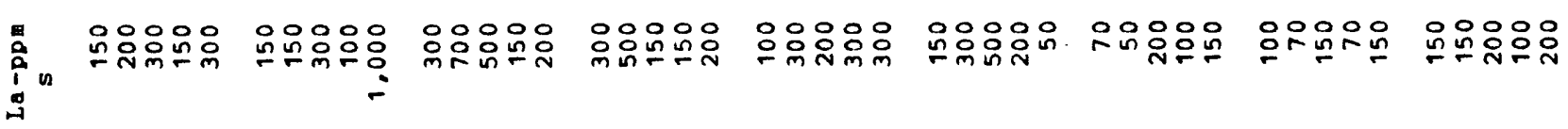

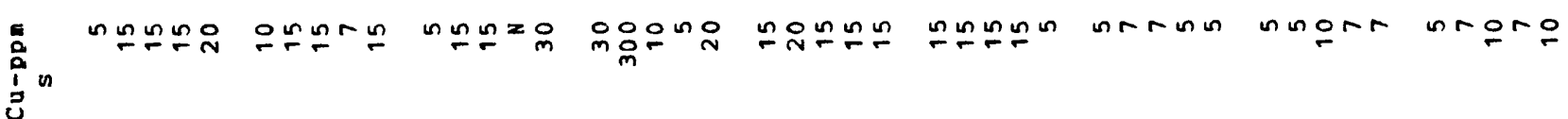

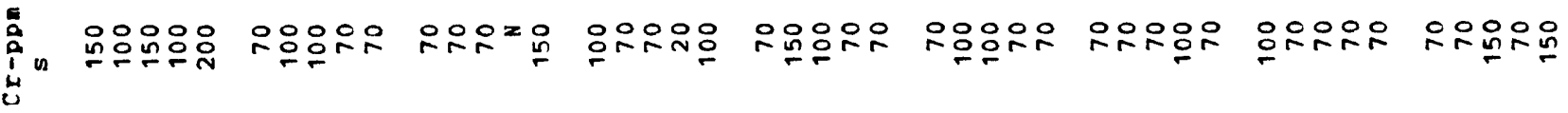

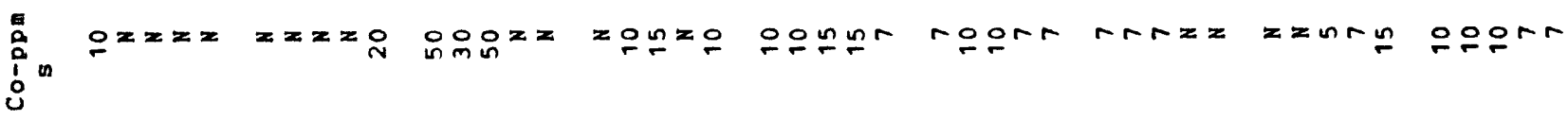

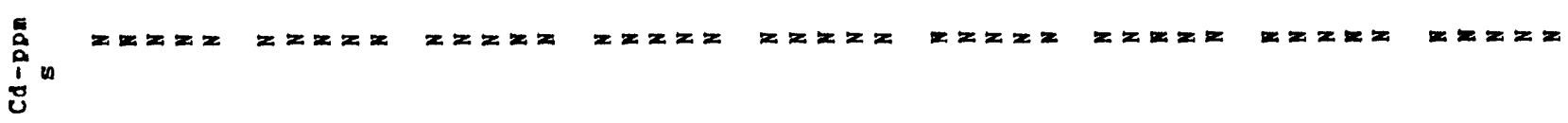

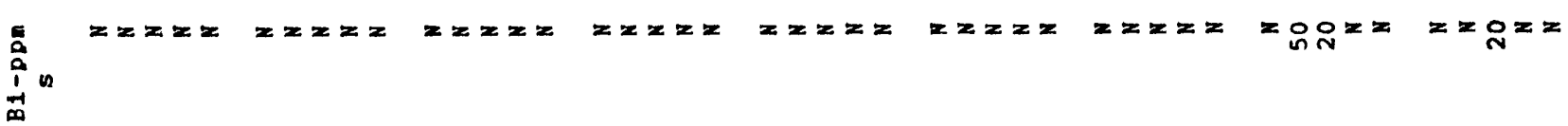
ín

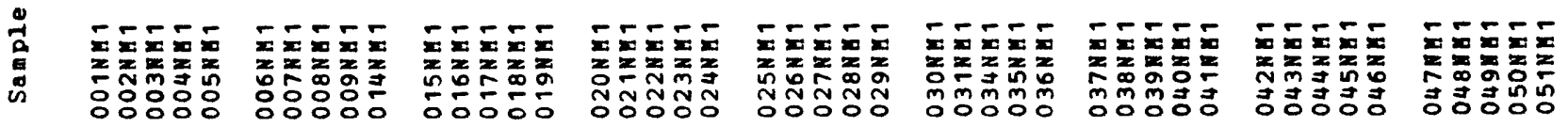


$\sum_{\substack{0 \\ 0}}^{1}$

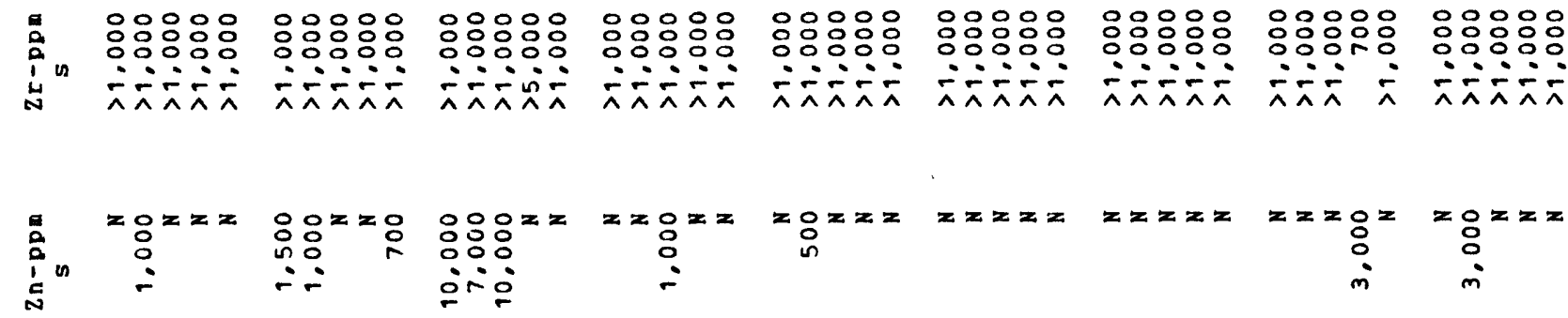

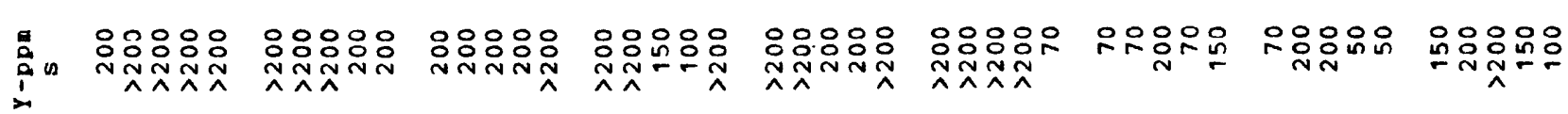

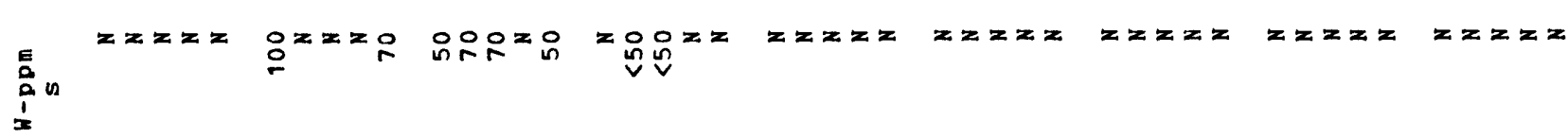

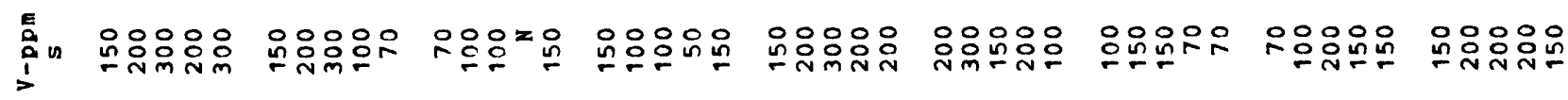

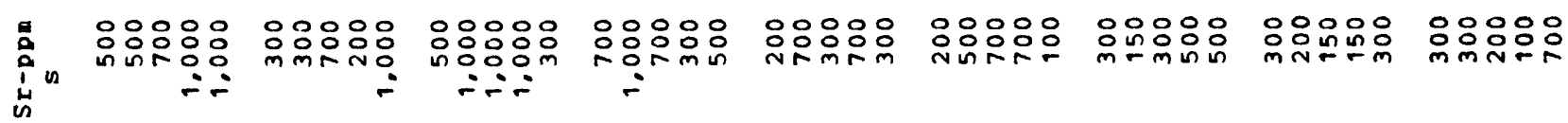

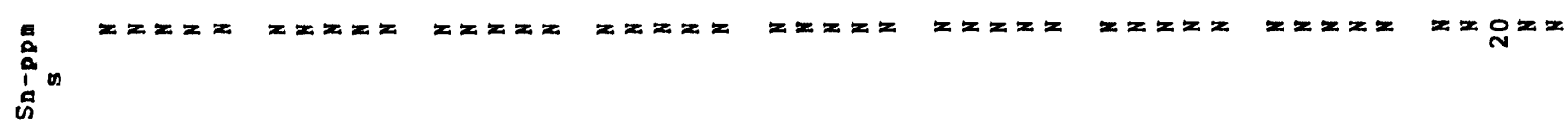

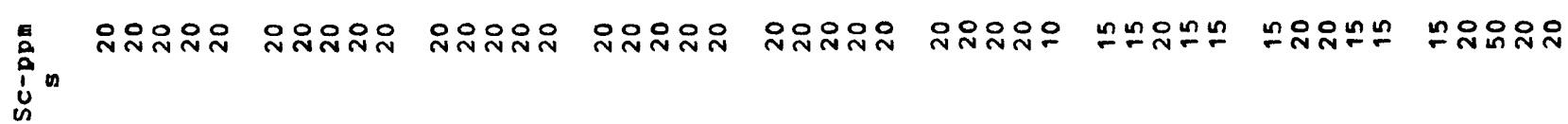

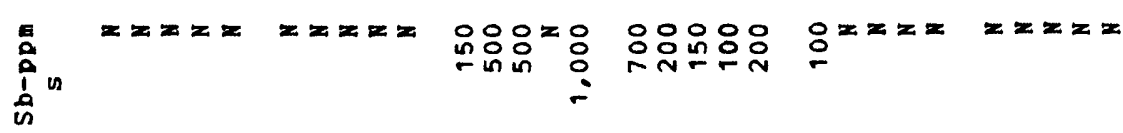
$z=2 x=$ $z x z z \quad z z z z z$

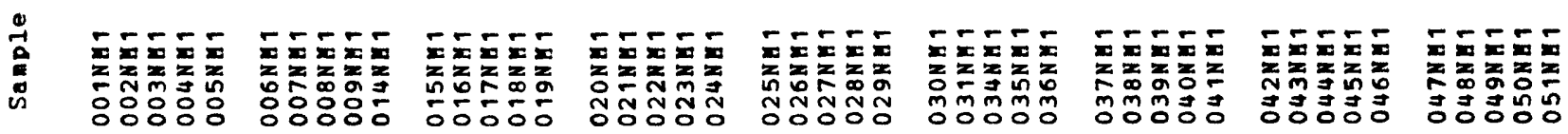




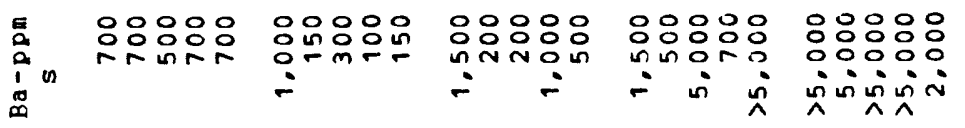

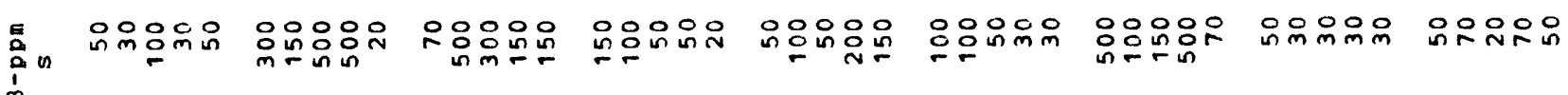<smiles>[CH][CH]</smiles>

$z z x z z$

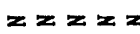

$z z z z$

$z z z z z$

$z z x z=$ in

in

$z z z z$

$z=2 x=$

$z z z z$

$z z z z$

웅

$=2 x=$

$z$

$\sum_{0}^{1}$ !n $z x z=$

$z z=z$

$z z z z \quad z z z z z$

$x x=x$

$z$

$x=z z$

$z z z z$

$z z z z$

$z z z z$ E⿱艹

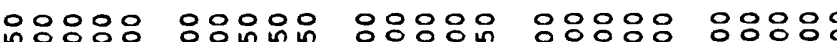

옹요웅우

응ㅇㅇㅇㅇㅛ

옹ㅇㅇㅇ

웅웅웅

苔象

$\because 000 \div$

$\because \because \because 0: \div$

0.0000

0.0000

00900

00000

00000

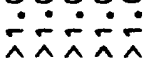

00000 $\vec{E}$

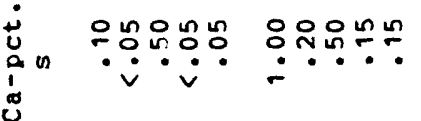

응유융ㅇ 웅영영

:ㅇ::융 $\because \because \because \quad \dot{\theta} \dot{0} \sin$ inisin

융융ㅇㅇ웅

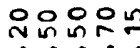

우융동느요

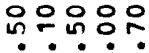

$\because \dot{\sim}$

$\operatorname{lin}^{2}$

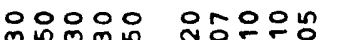

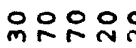

능ㅇㅇㅇ

웅ㅇㅇㅇ

을윰윰웅

00000

nonno

운으는유 :

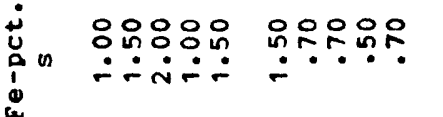

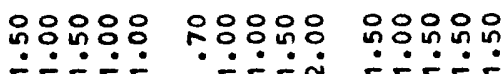

응융요운

융응ㅇㅇㅇ

응웅요

옹융ㅇㅇ

응 is

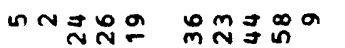

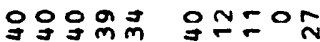

ํำกำฝำ

ヨニラณำ - inín

$\because \because \because \div$

$\because \div \div$

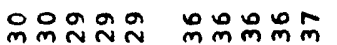

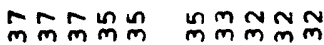

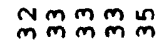

กับำกำ

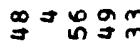

Nรmon

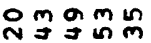

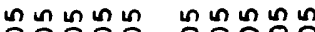

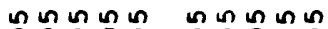

nnn $n$ n

นnก

พ

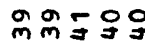

웅영워겨

으우웅ㅇㅇ

으응ㅇㅇㅇㅇ 우유웅ㅇㅇ

우으으으음

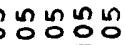

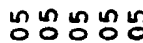

농으응으응

กัพธกัก

ด ๆ每的

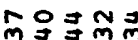

ํํ공ㅇ

กำ ₹0 m

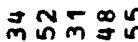

늠ํำ

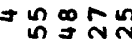

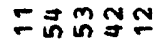

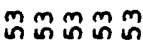

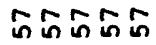

败疑的

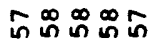

กำ路路

구요

织出㔯芯的

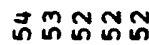

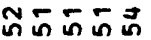

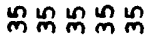

只品紫品品

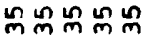

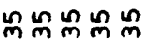

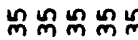

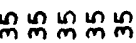

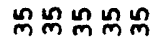

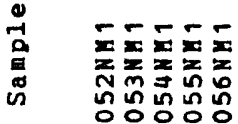

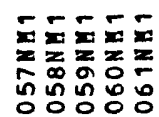

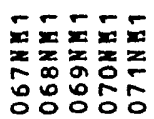

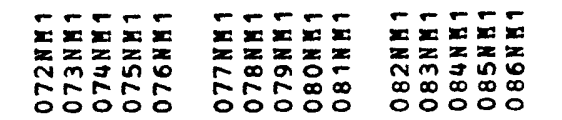

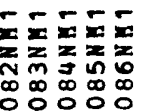

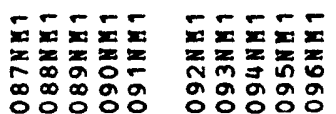




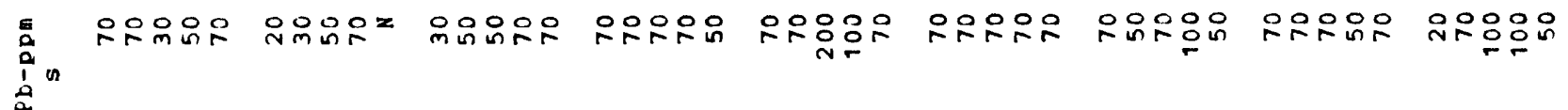

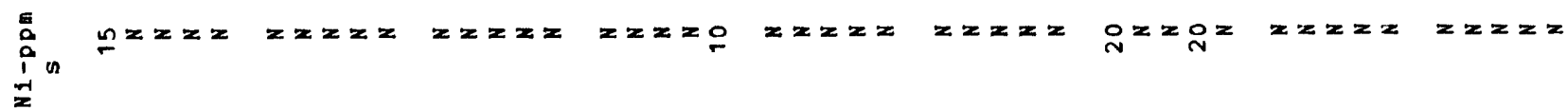

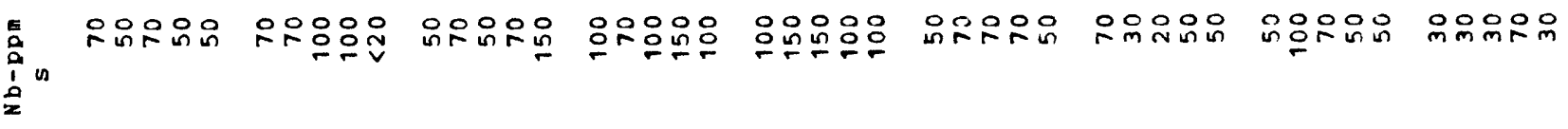

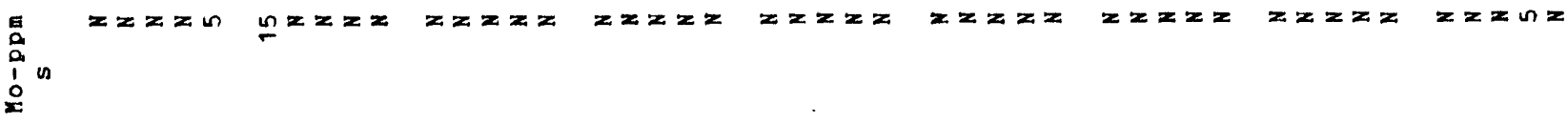

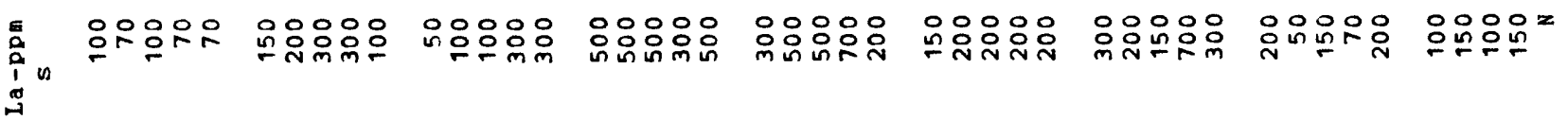

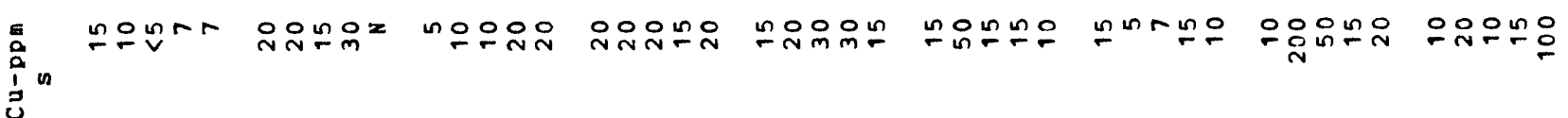

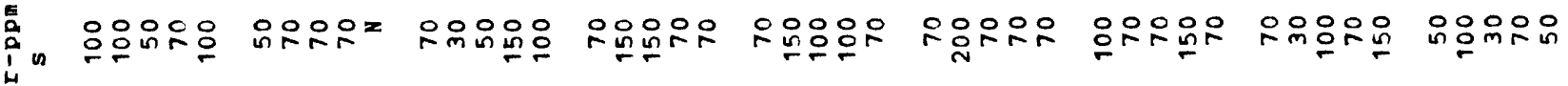
(u)

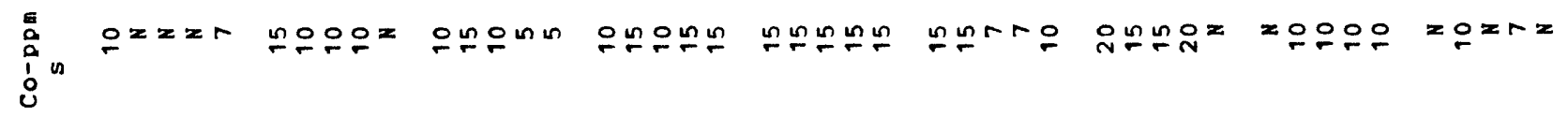

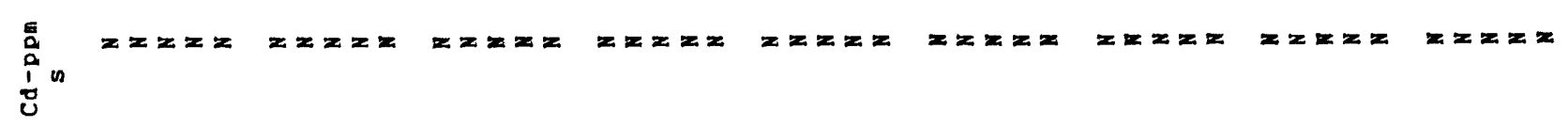

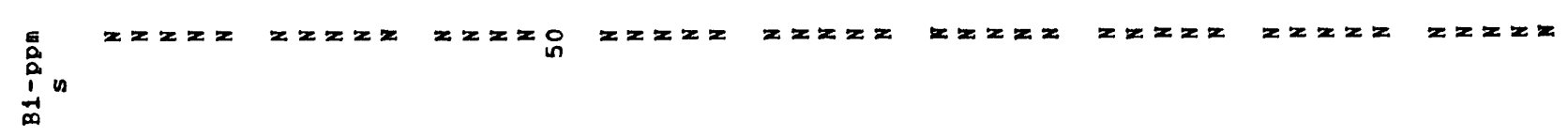
兽 


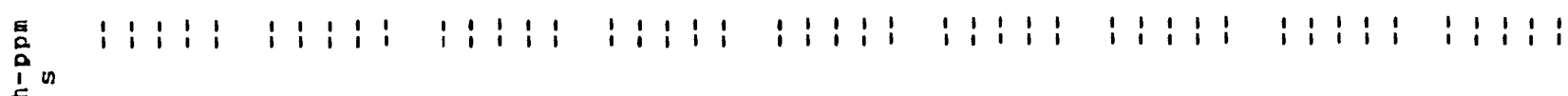
畜"

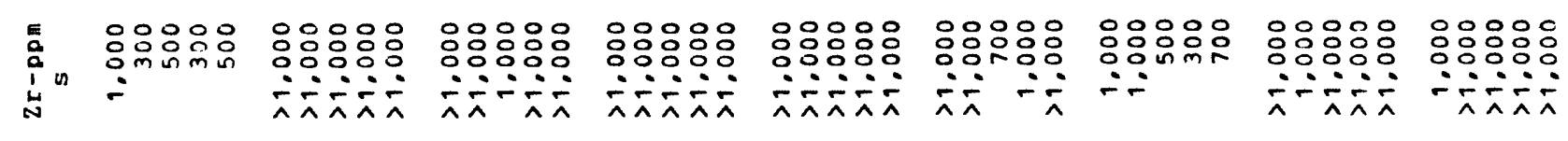

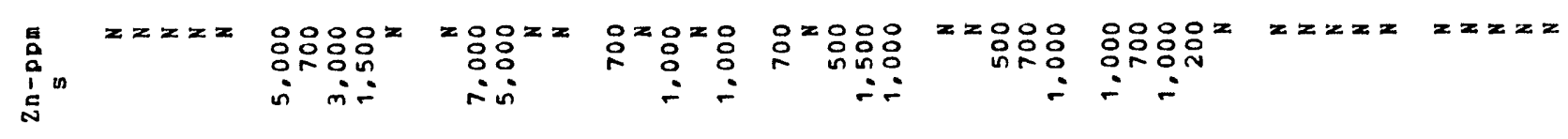

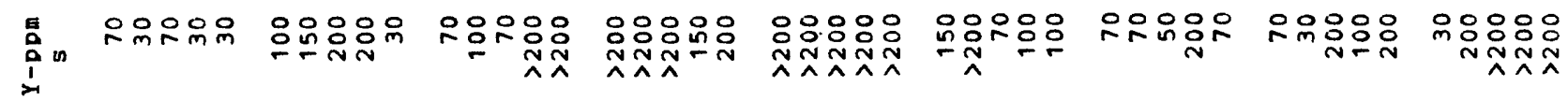

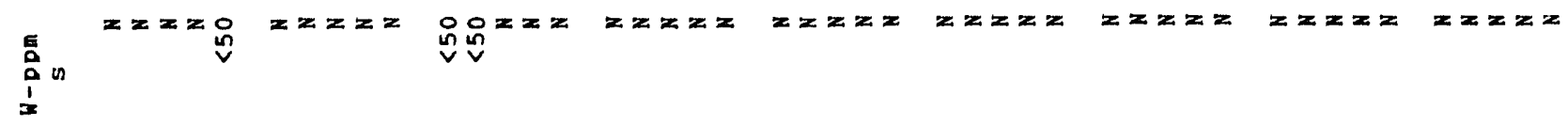

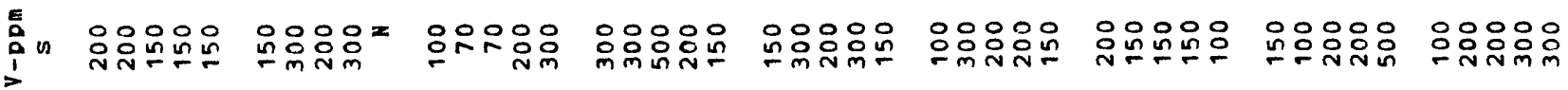

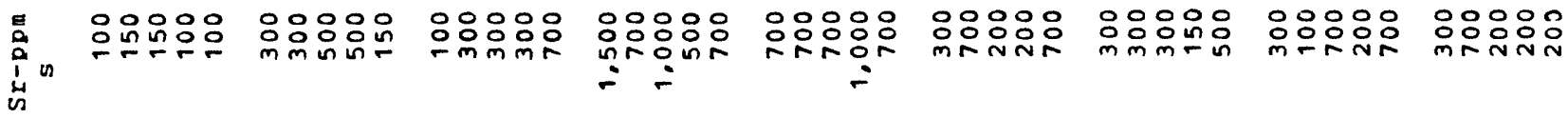

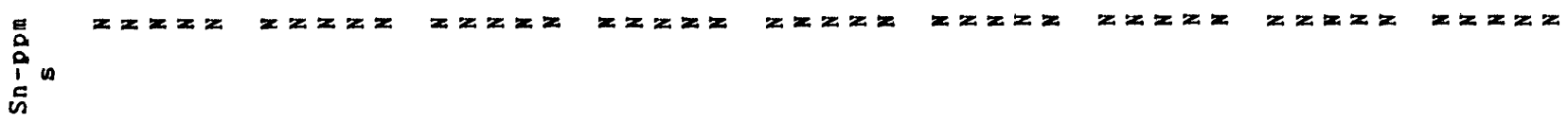

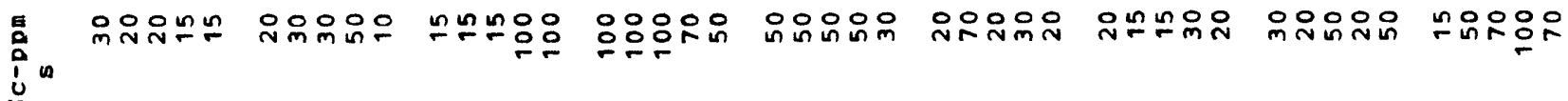
$\dot{m}$

$\underset{n}{\stackrel{\infty}{a}}$
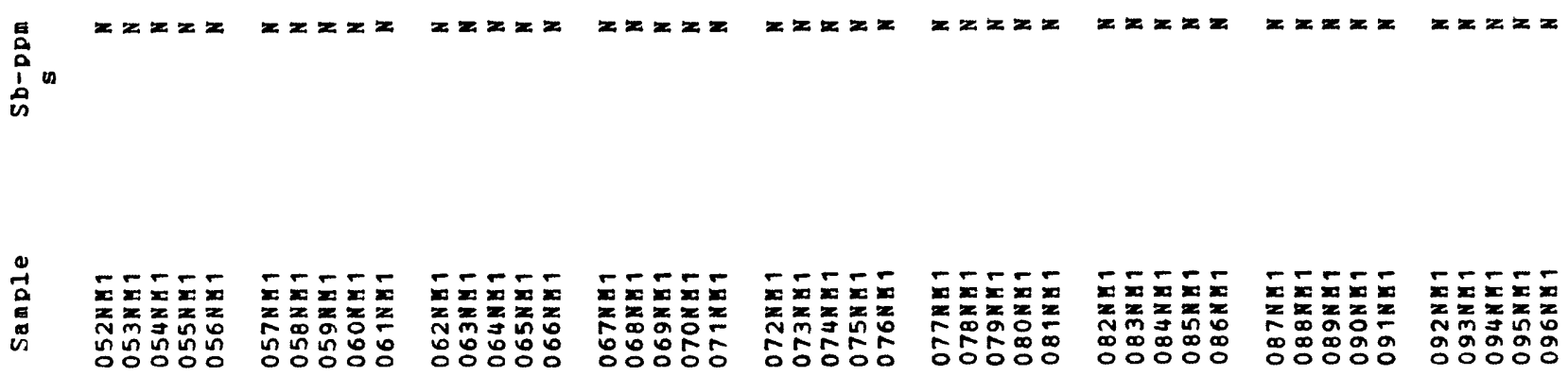


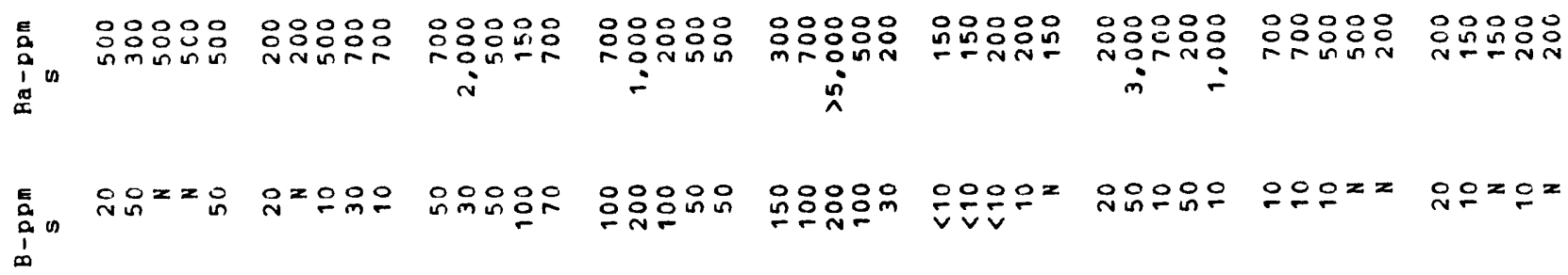

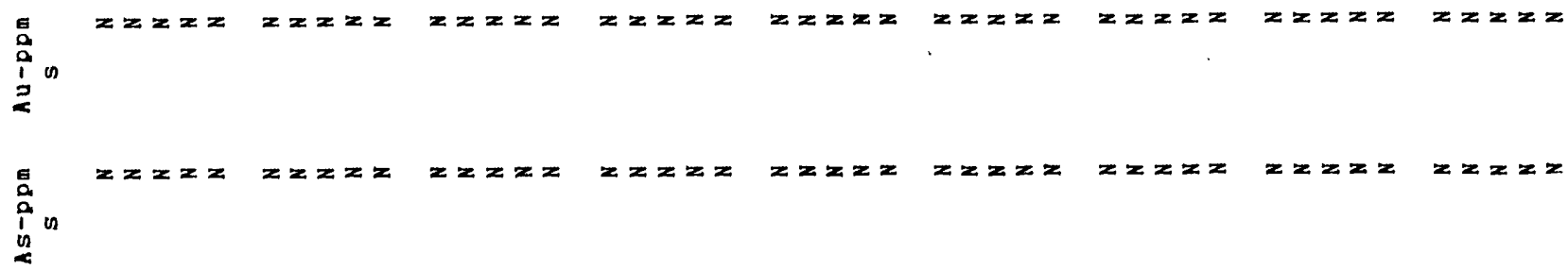

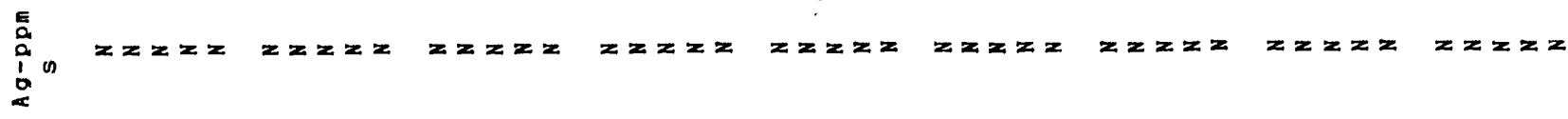

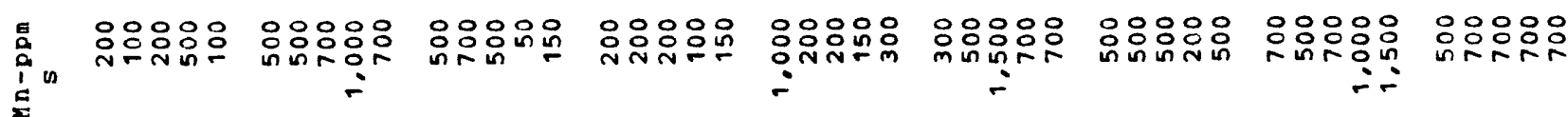
落

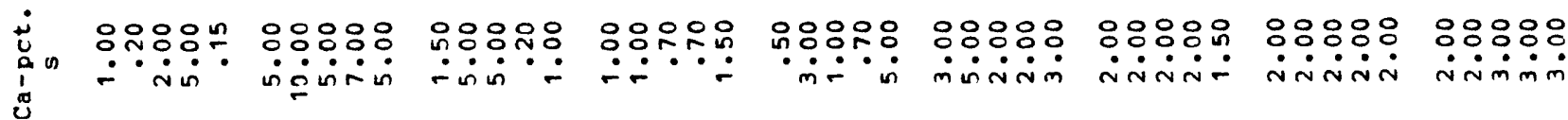

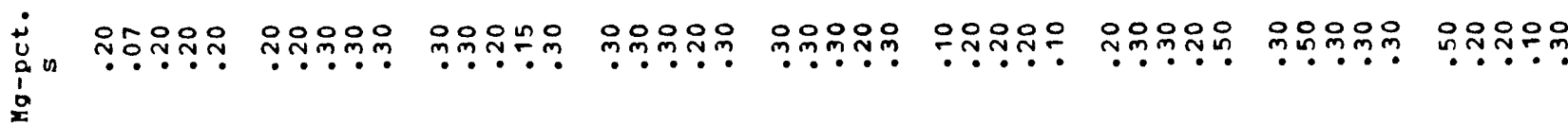

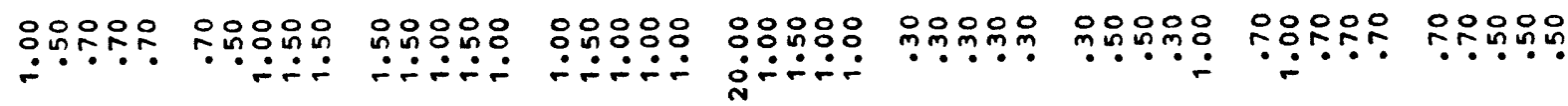

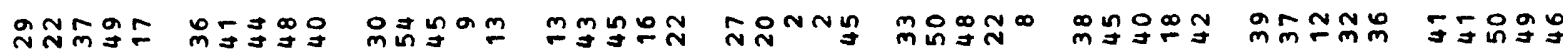

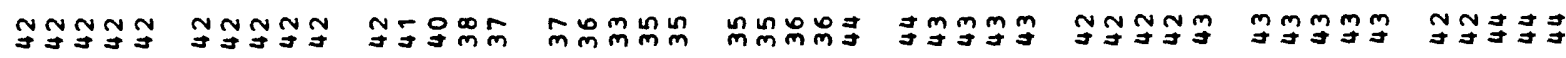

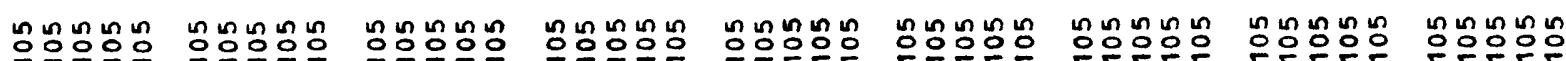

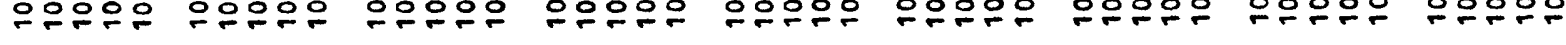

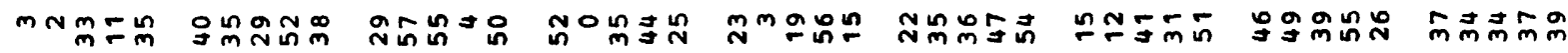

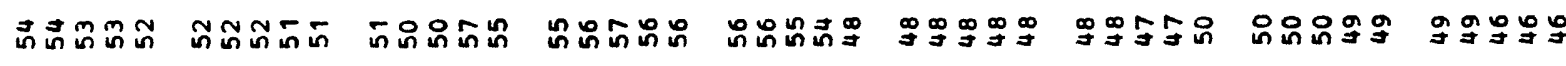

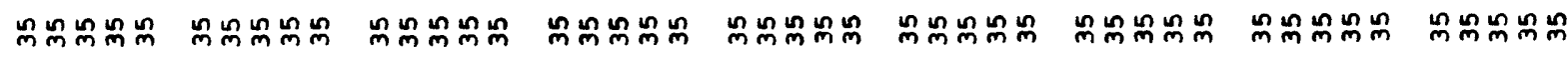

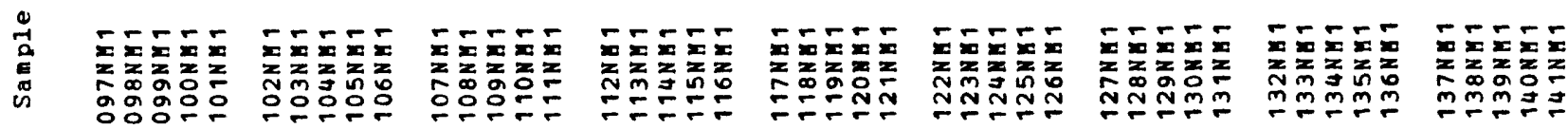




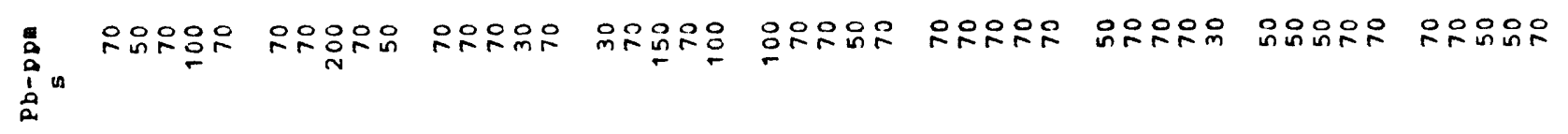

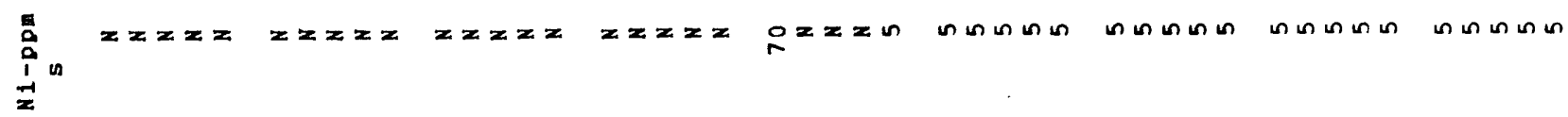

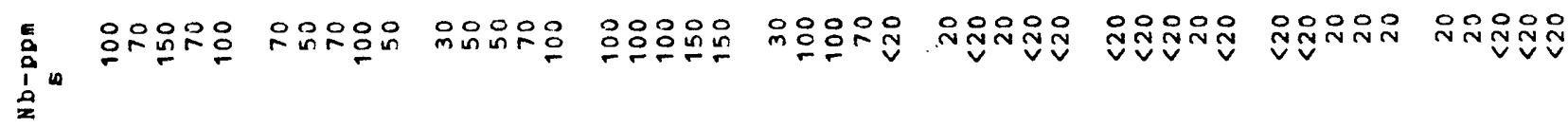

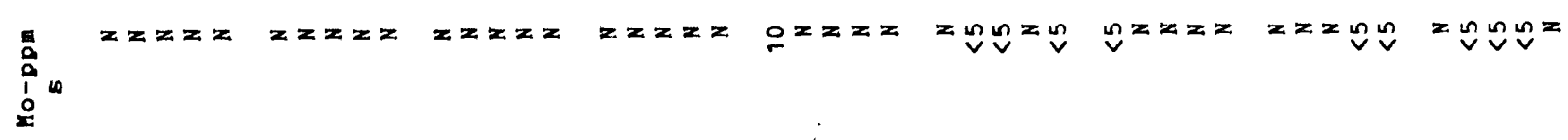

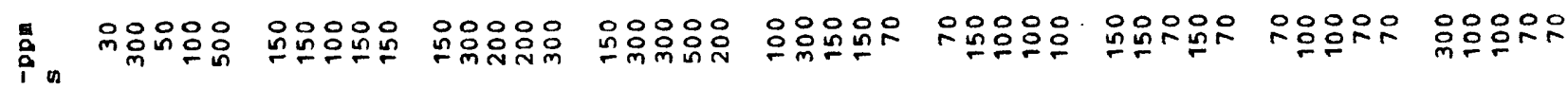
in

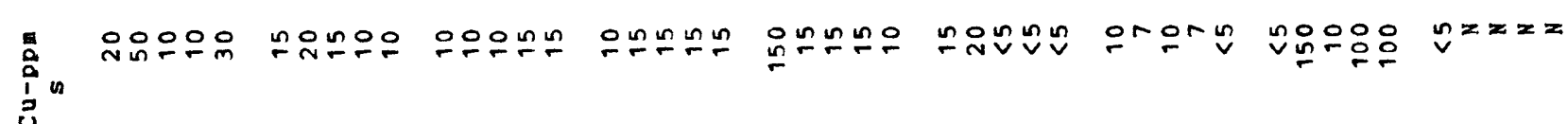

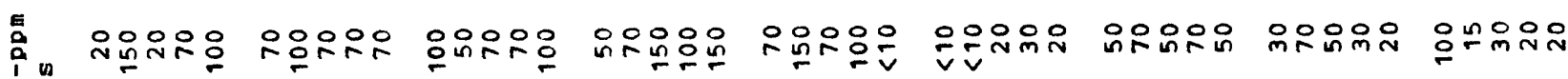
出

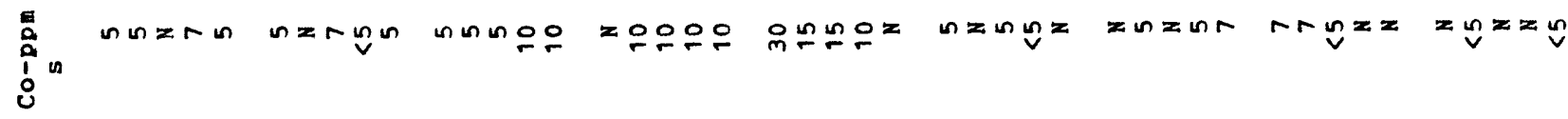

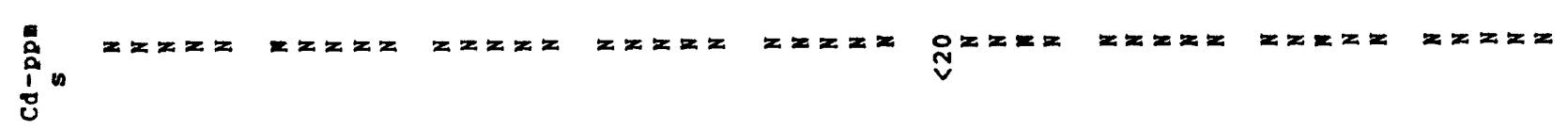

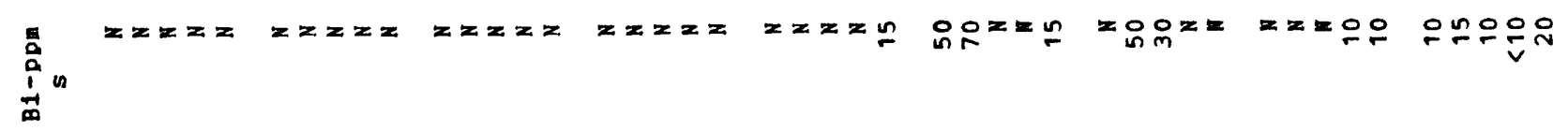
$\dot{m}$

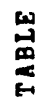

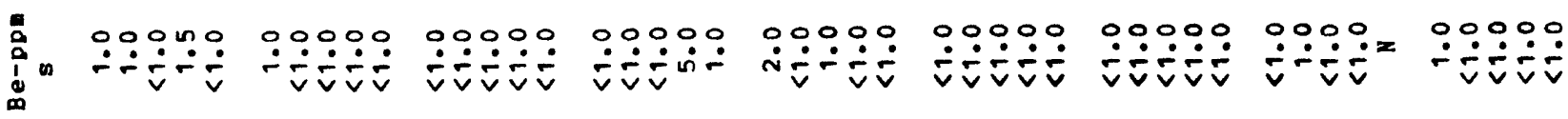

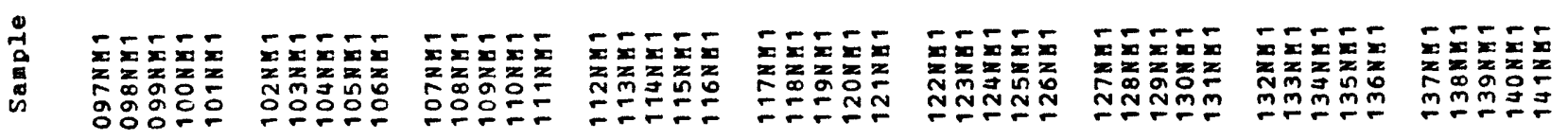




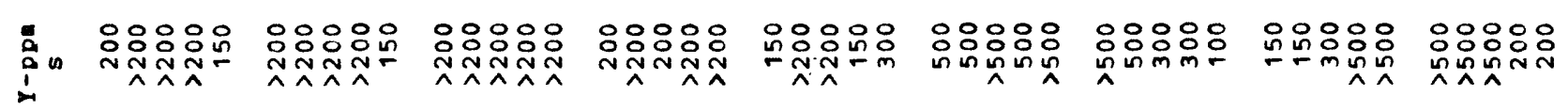

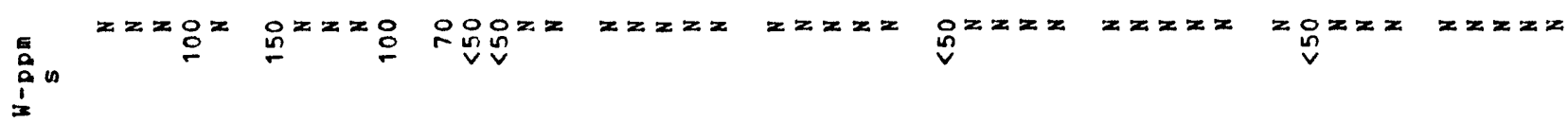

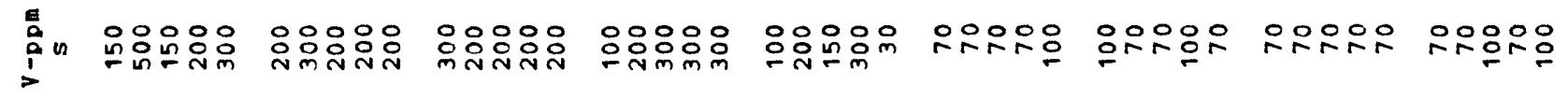

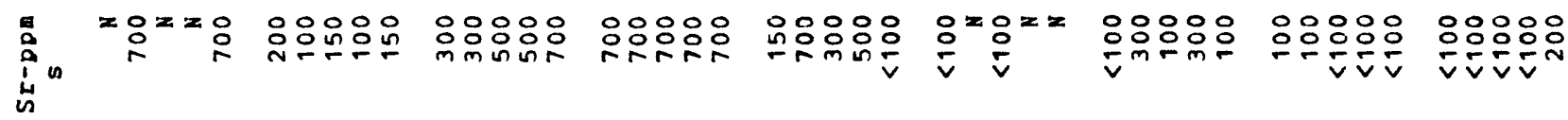

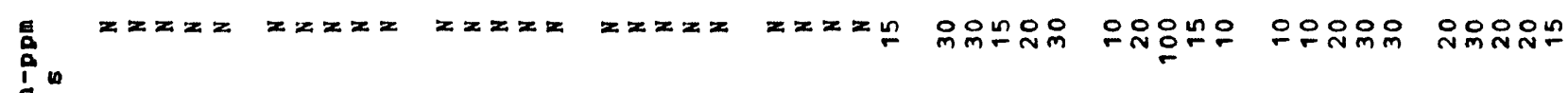

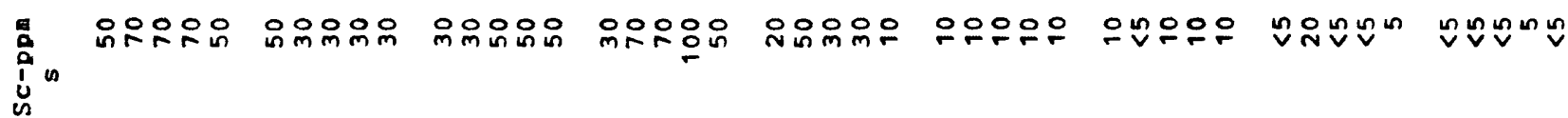
$\dot{m}$

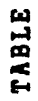

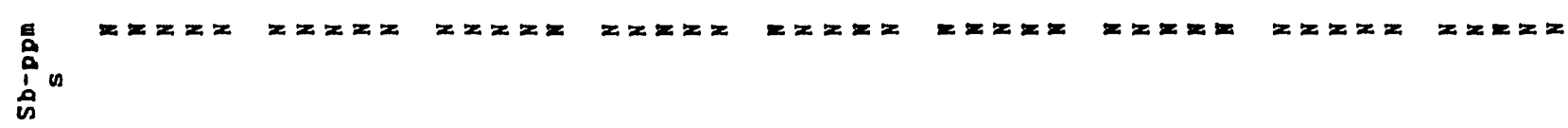

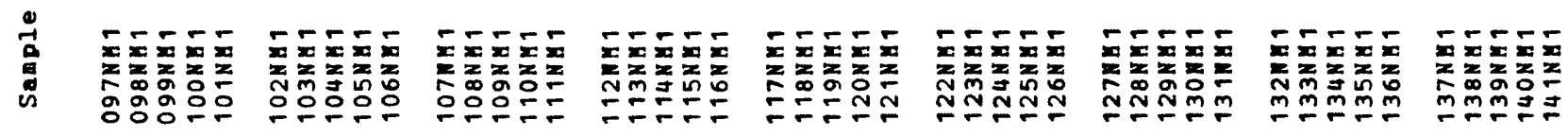




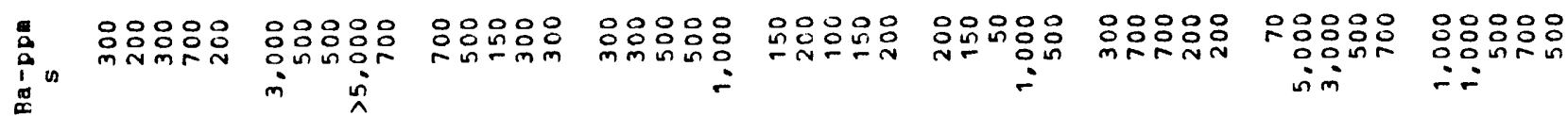

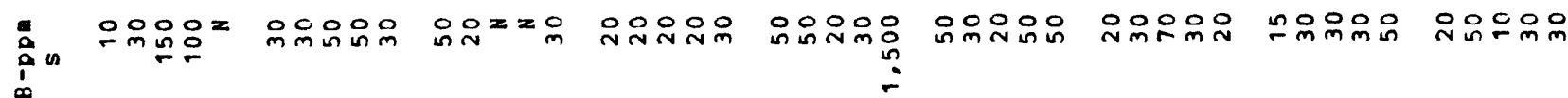

$\stackrel{1}{2}$

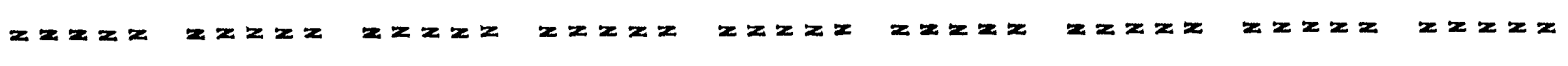
in

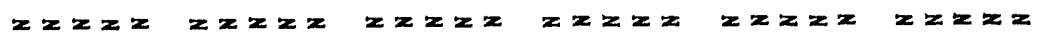
$\operatorname{lom}_{\substack{0 \\ 0}}$

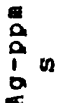

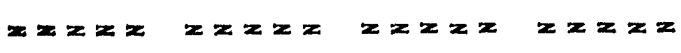
$z x z z$ $z x z x$ $z z z=x$ $z z z z z$ $z z x z$ in

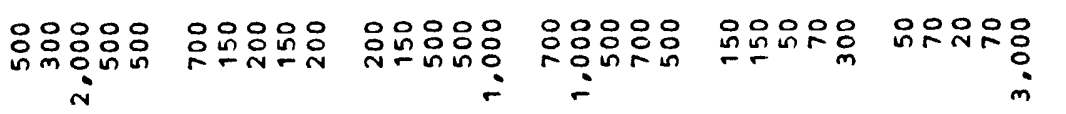

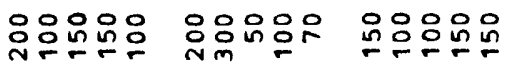
$\dot{\bigsqcup}_{\substack{\dot{1} \\ \dot{1}}}$ n no00 00000.00000 00000 수숫

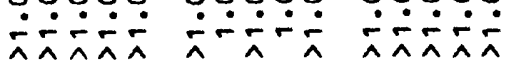
0.090 OONO:D 00000 .0.0.0 0.000 $\vec{H}$

오융용요

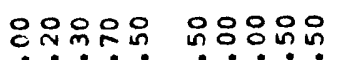

옹으요요

옹으으으응

농ํํㅇํㅇำ

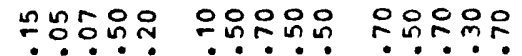
in $\therefore$ nरं $\because \div \div$

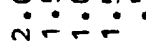

荒证

웁유온유. 으윴윳웅

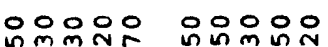

음유으늄요

우옹으응

우우우으으

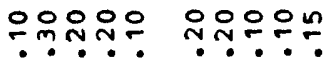

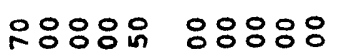
-

응

恣

$\dot{m}$

$\stackrel{2}{2}$ ํํㅇํํㅇํㅇ응 ํํㅇํㅇㅇㅇㅇㅇ

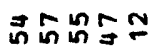
กำกี่์ก

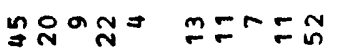

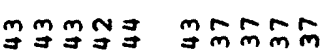

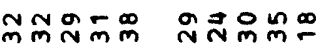

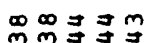
ํํㅇํํㅇํำ

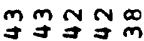
ํํㅇํํㅇํㅇ응

응용으 융용용

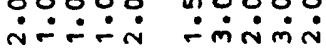
옹웅유 $\dot{n} \div \cdot \dot{r}$

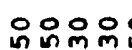

운유옹무 웅용유 ஸ்:-

웅용ㅇㅇ ப்டாட்

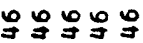

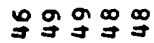
กำกับ

올ํำm

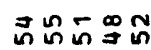
กิ๊

กะก每

MกN 요우 ำ ํํำำ

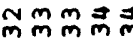

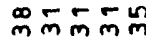
ํํㅇㅇํㅇํㅇํํㅇํㅇ ํํㅇํㅇ응ํㅇ응

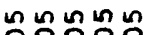
ํํㅇํํㅇํㅇํㅇ

แีะกำ

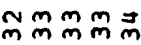

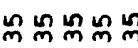
寻专牙

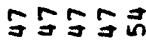

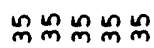

ว กิรีตัต

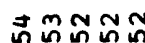

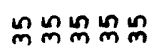

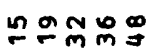

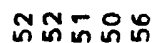
品藏出的品

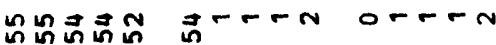

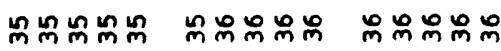

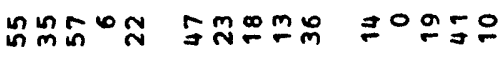




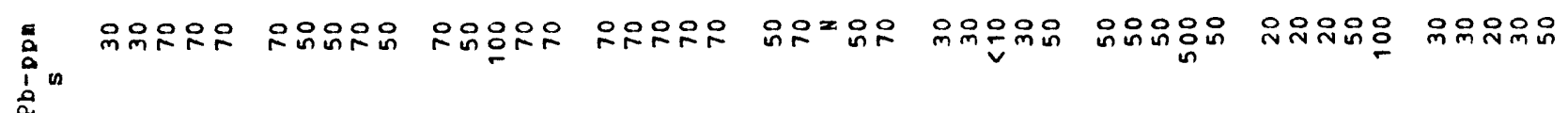

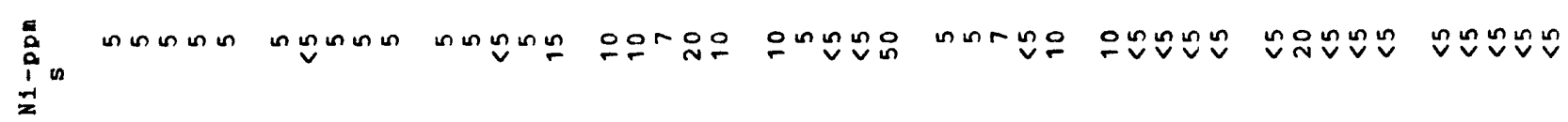

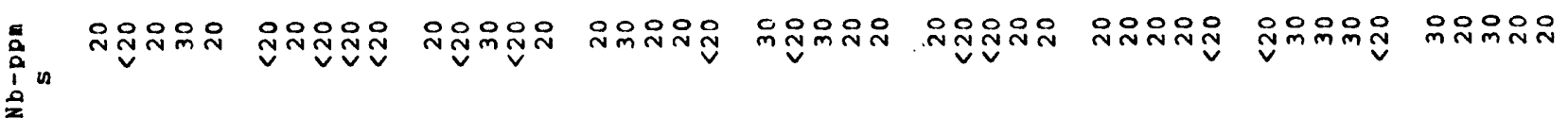

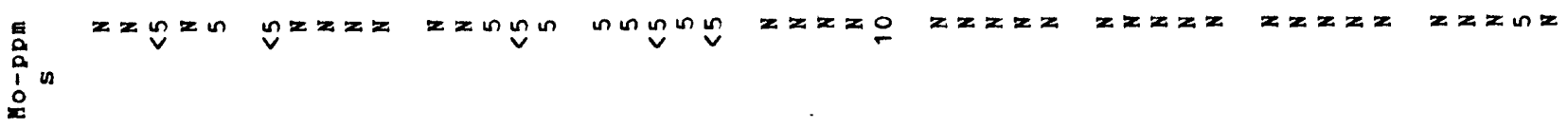

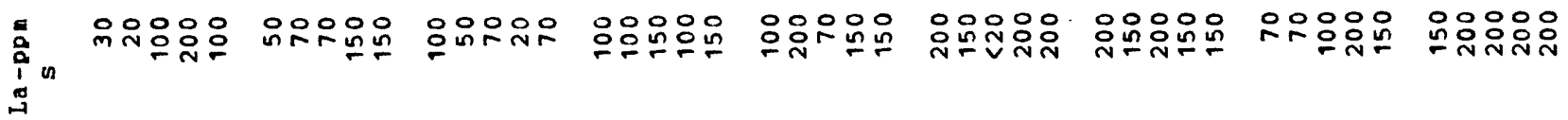

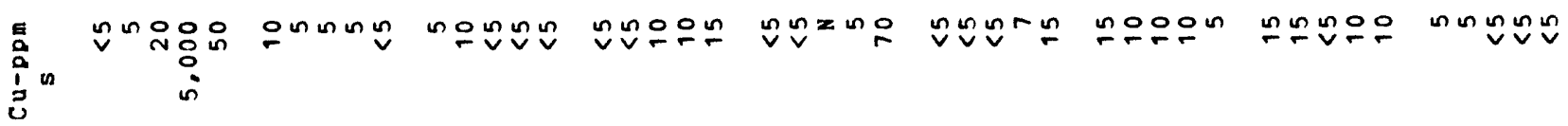

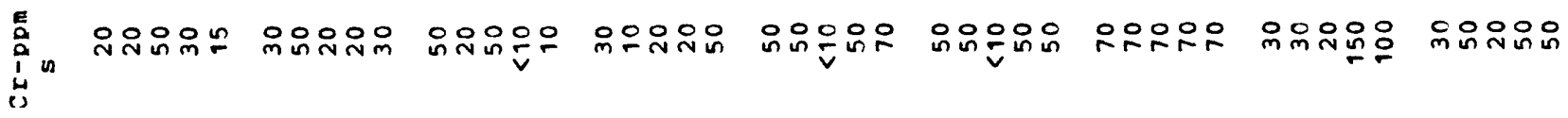

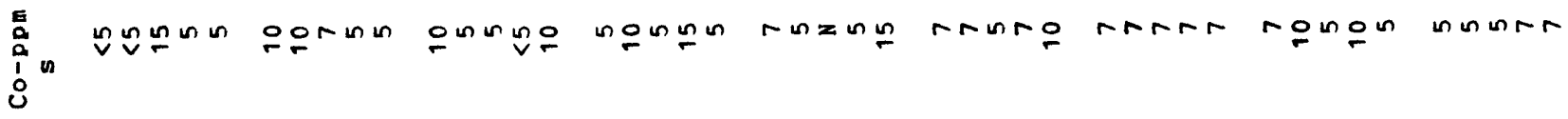

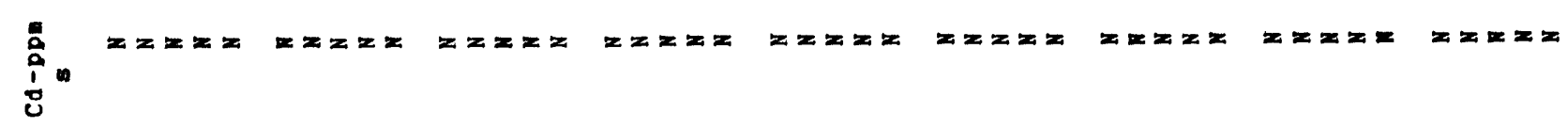

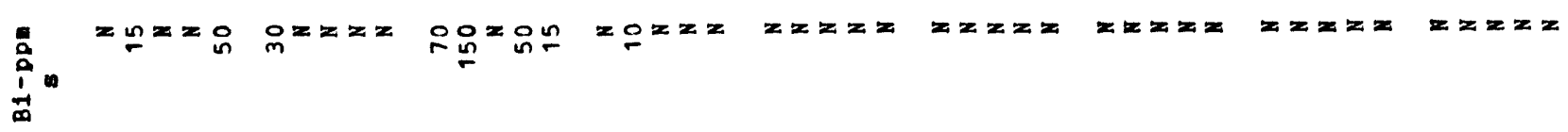

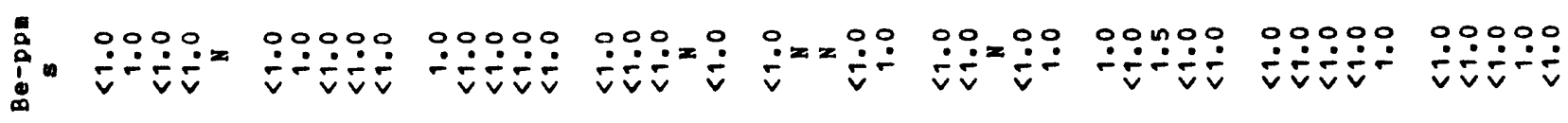

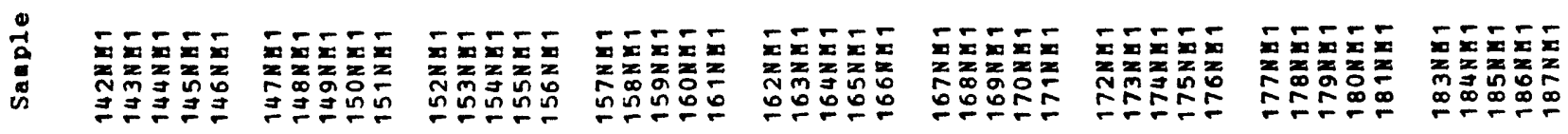


$\sum_{\substack{0 \\ 0}}^{0}$

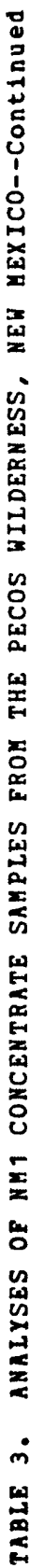

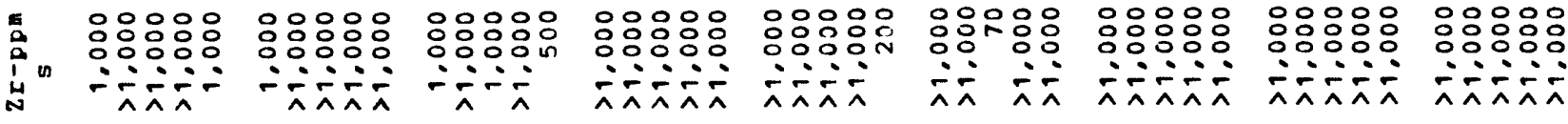

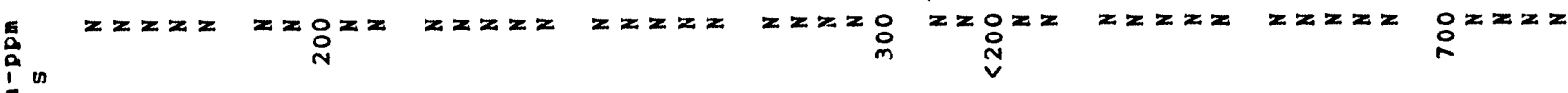

ง

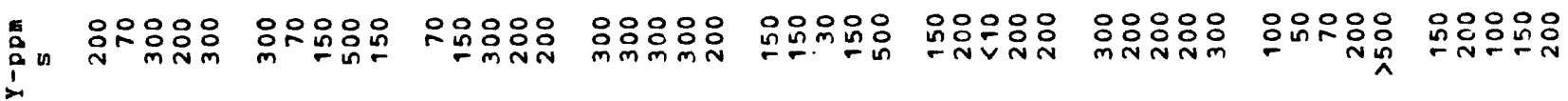

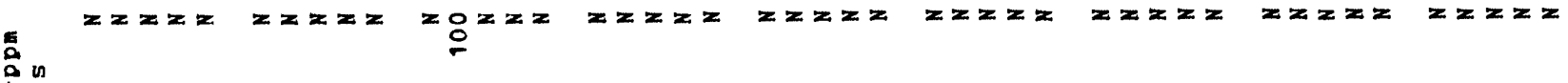

i

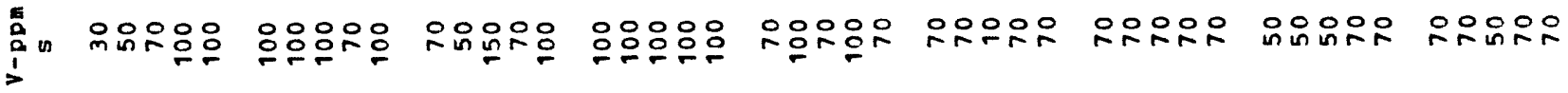

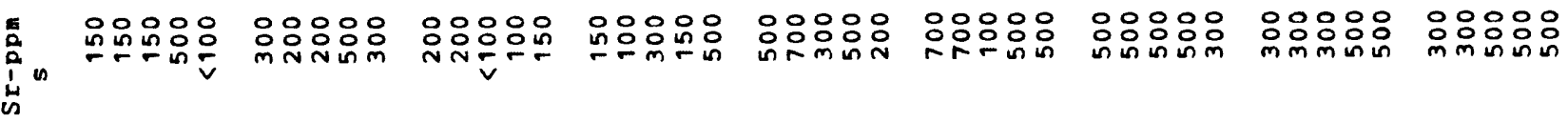

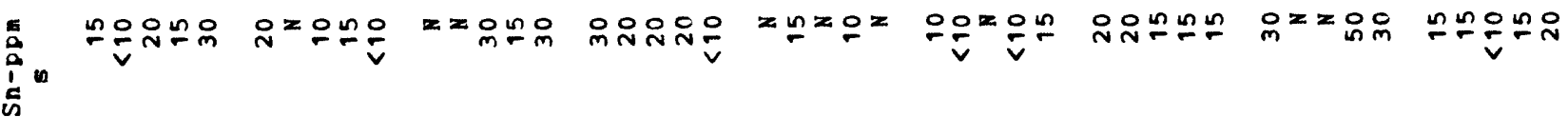

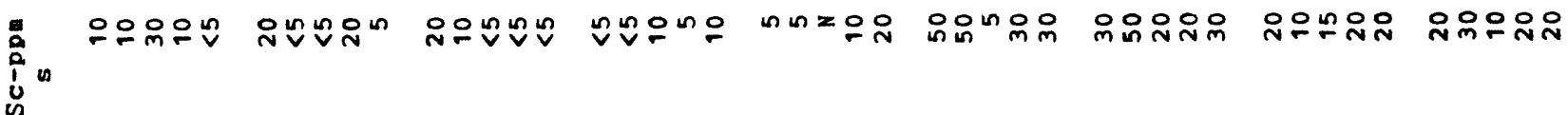

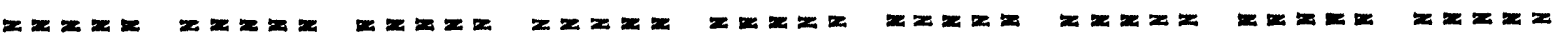
盟

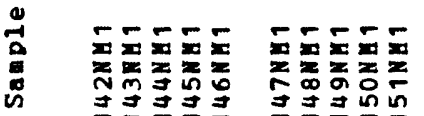

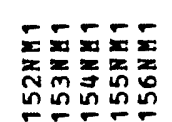

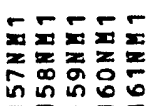

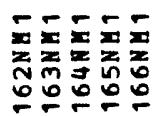

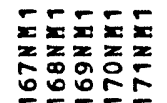

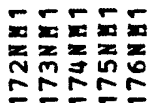

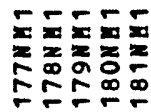

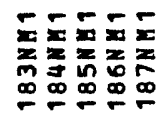




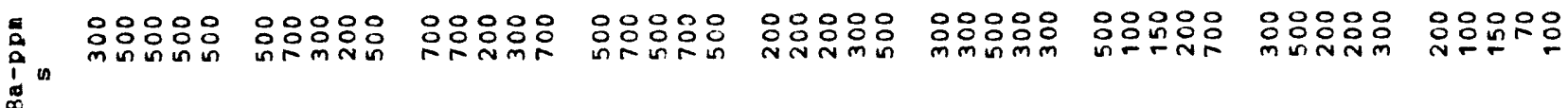

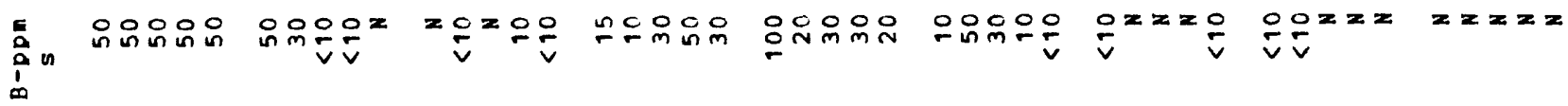

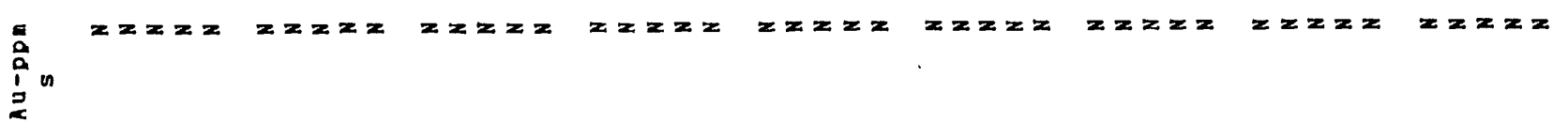

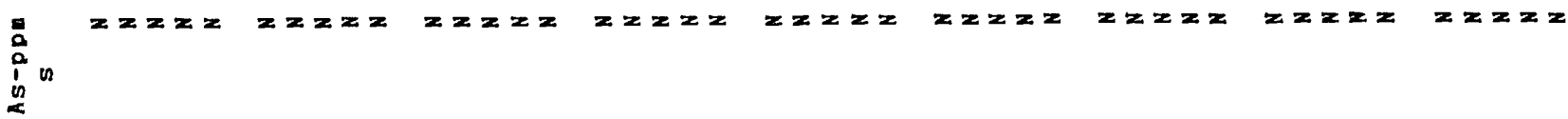

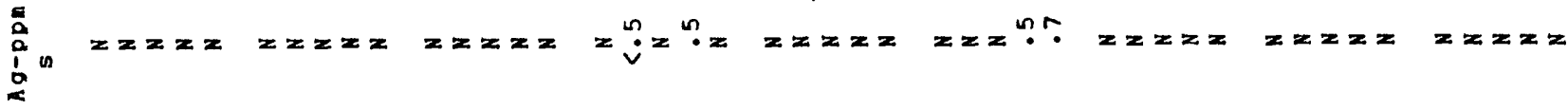

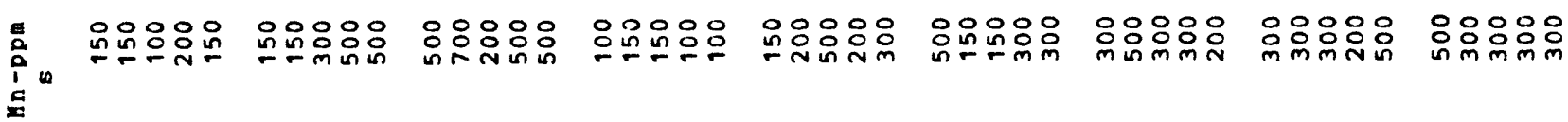
䒧

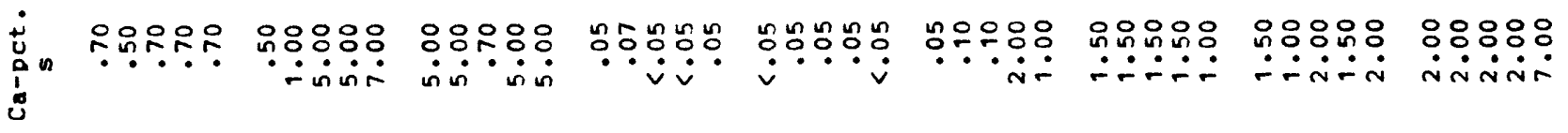

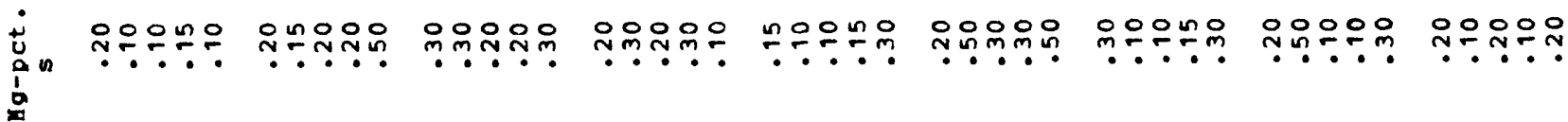

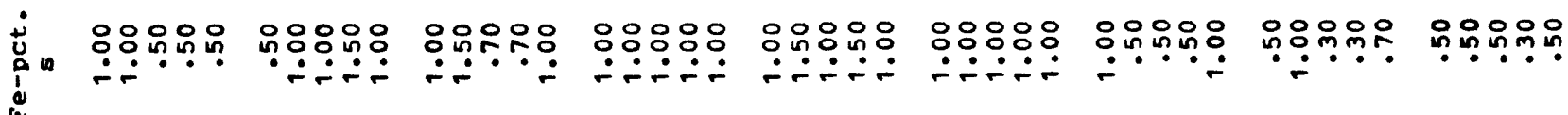
잉

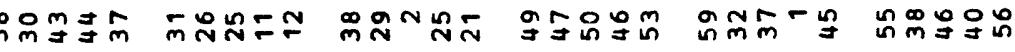

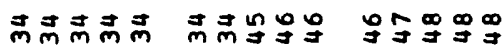

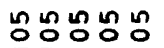
ก ก แn n 웅우응ㅇㅇ응

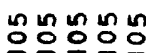

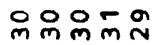
ㄴํㅇํํㅇํㅇํㅇ

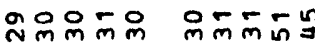
nn $n$ nn 응ㅇㅇㅇㅇㅇㅇㅇㅇ ํํㅇํํㅇํㅇํㅇํㅇ

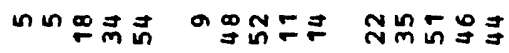
우요 ํํำํำํํำ ○一的思离

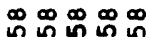

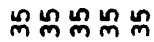

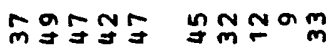

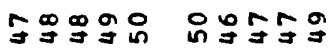

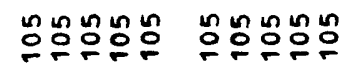

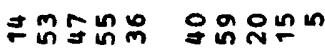

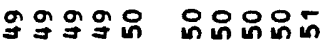

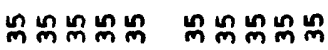

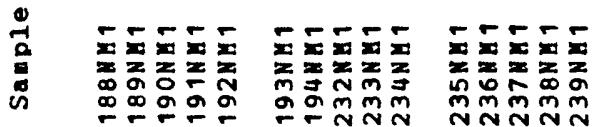

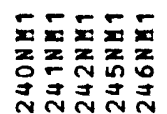

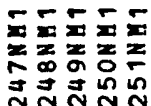

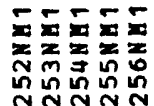

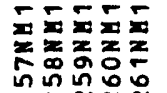

กิก

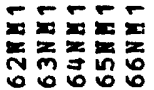

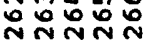

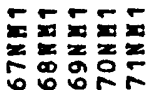

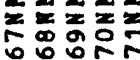

ํํำกั 


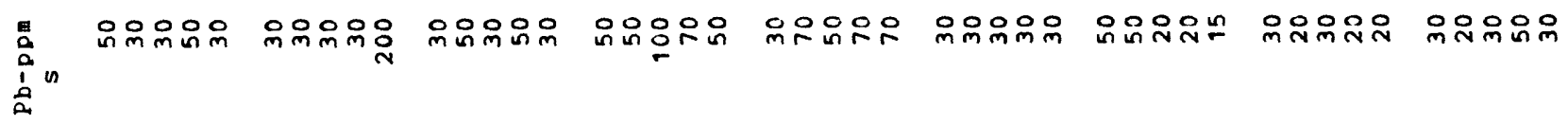

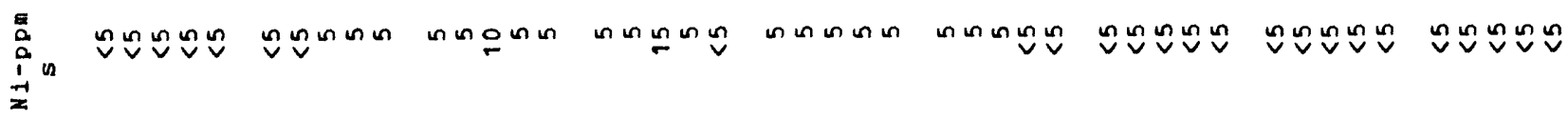

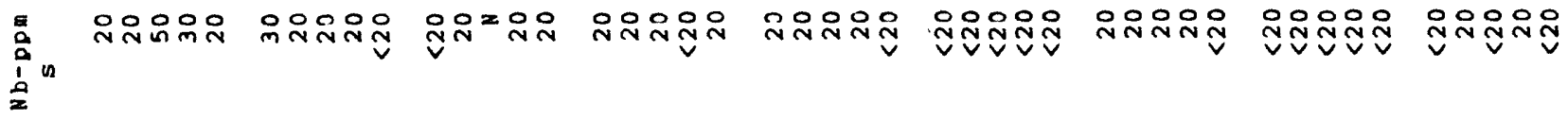

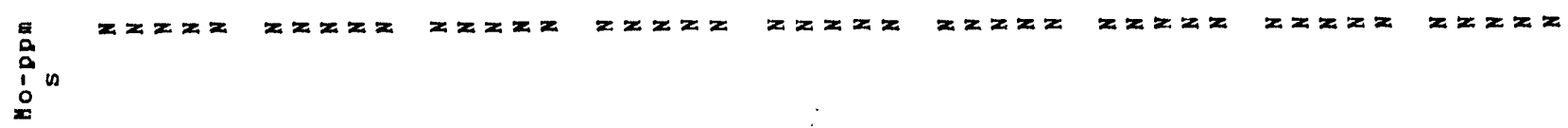

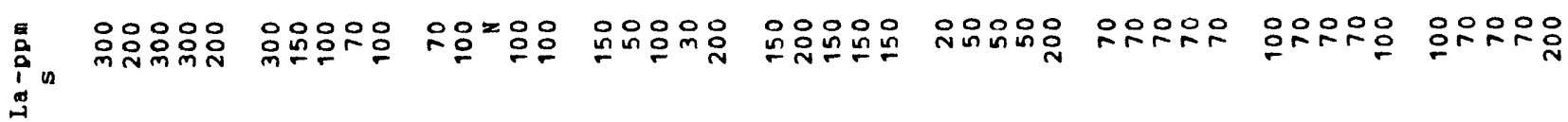

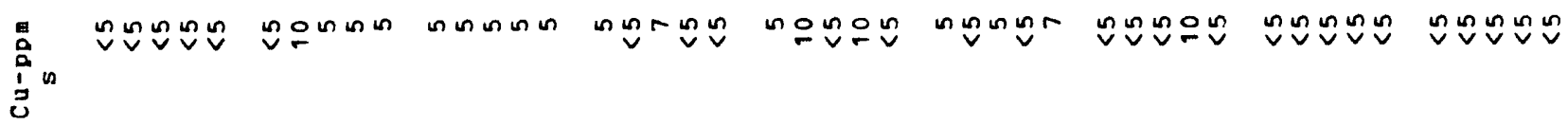

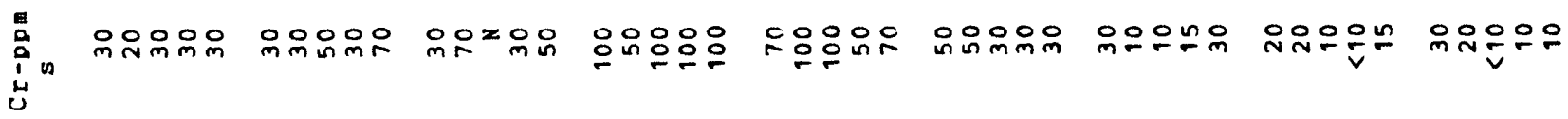

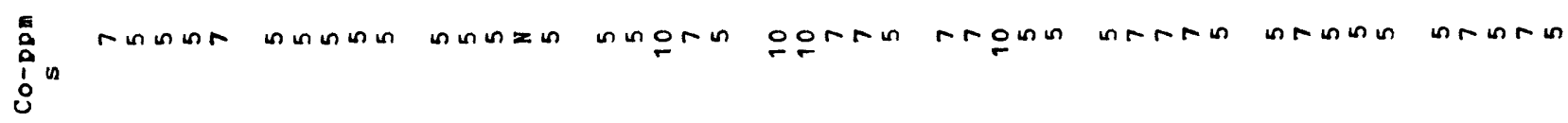

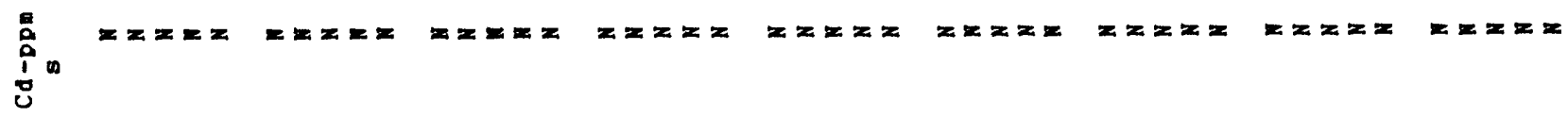

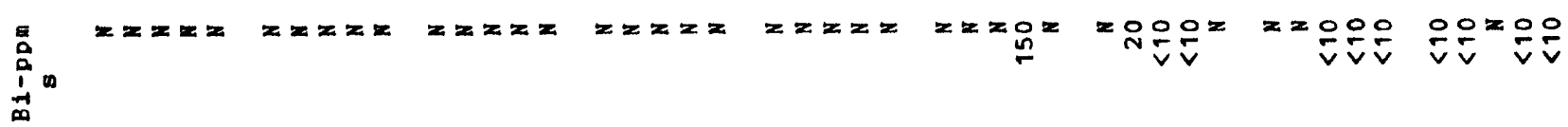
$\dot{m}$

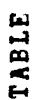

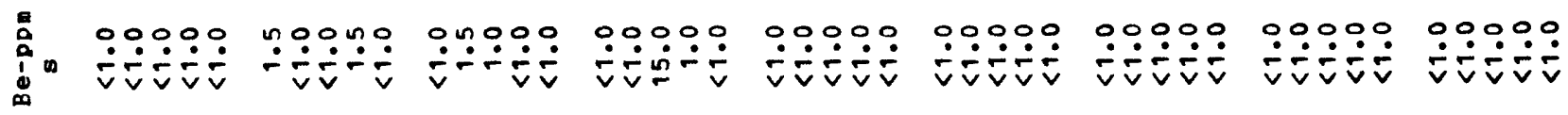




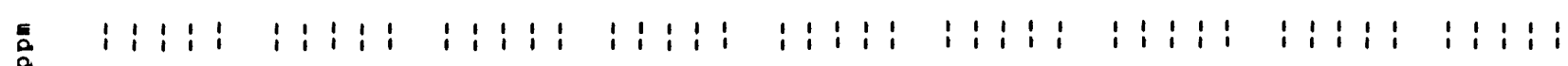
$i^{1}$ in

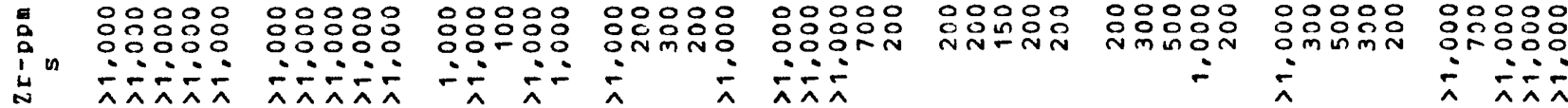

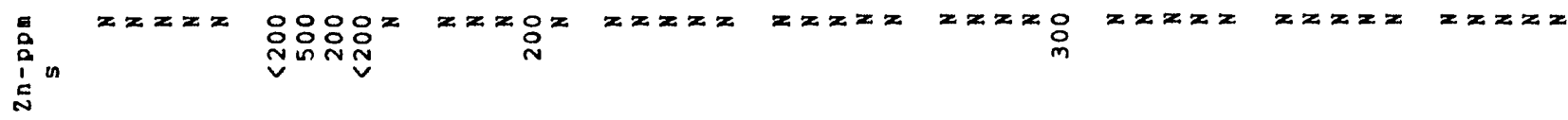

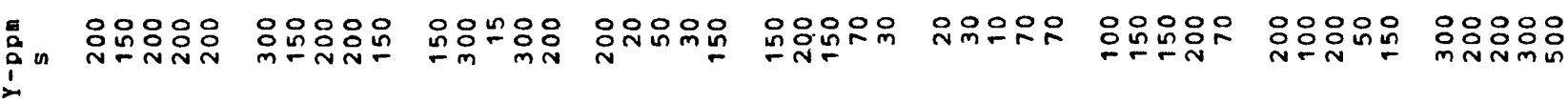

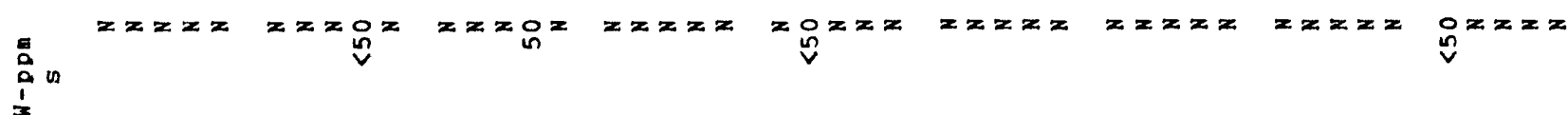

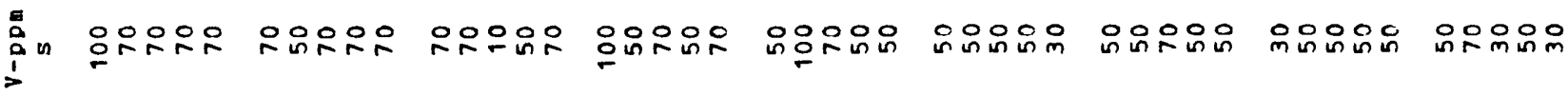

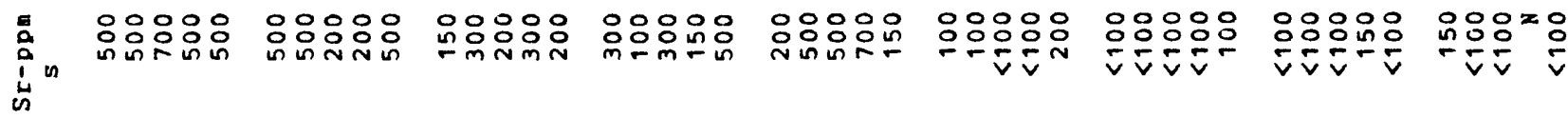

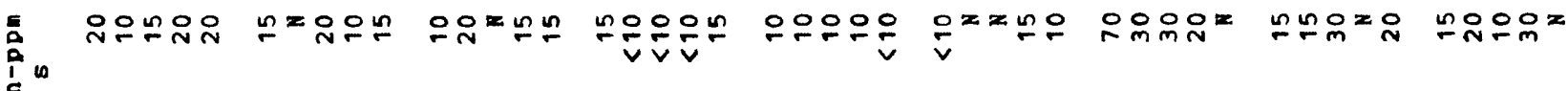
is

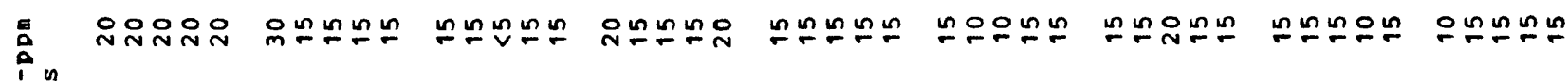
is

总 $=z z z=2$

$x z x=2$

$z=x=x$

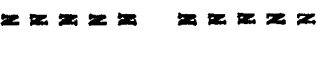




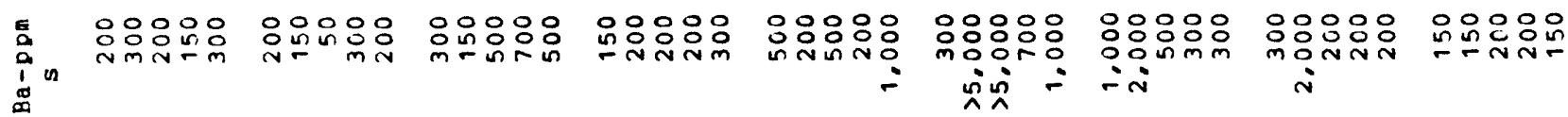

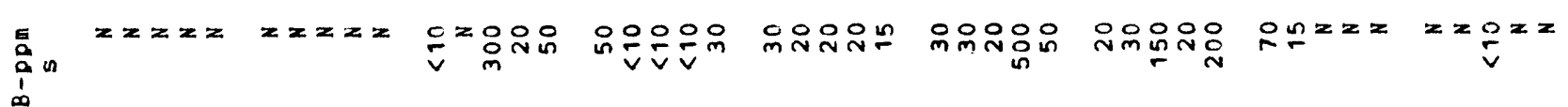

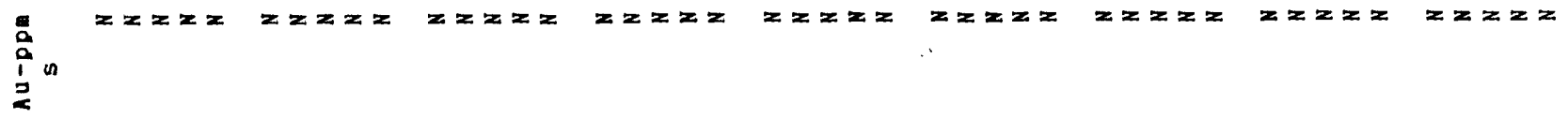

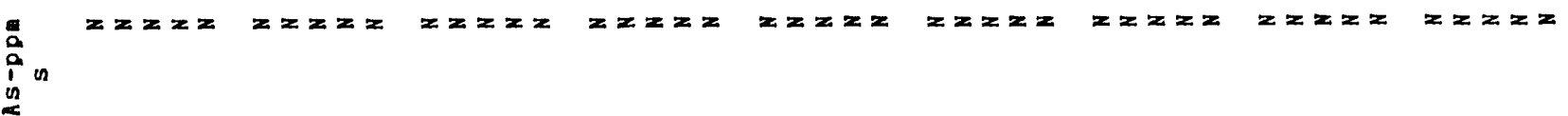

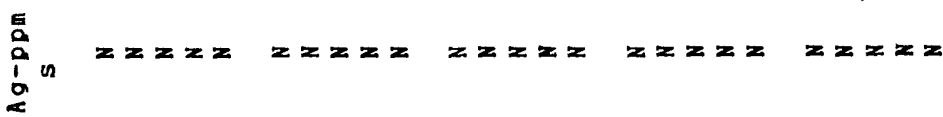

$z=z z=z z z z=z z z z z z$

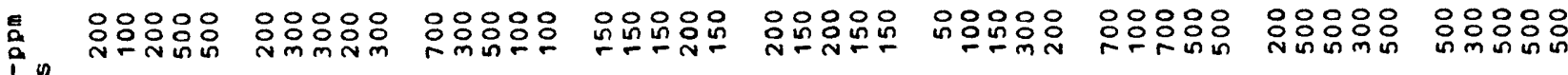
ca

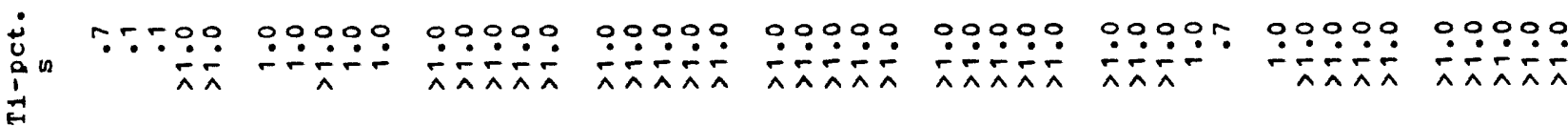

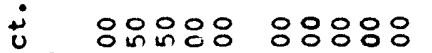

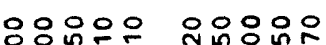

응유웅응

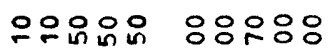

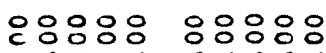
in m.

$\because \cdots \dot{\sim}$

… $\because \dot{\sim}$

तंत्रmं

mंn்m

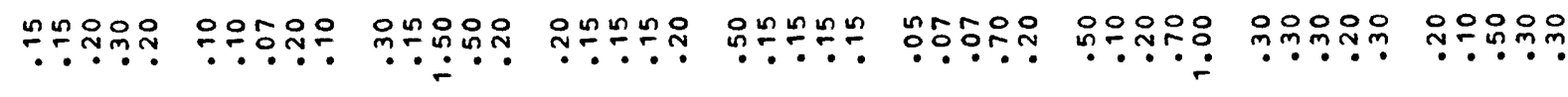
:

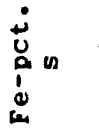

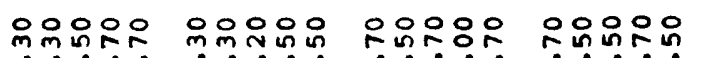

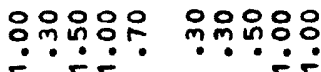

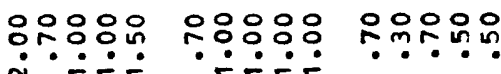

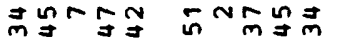

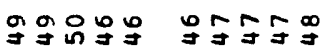

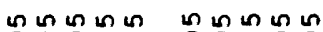

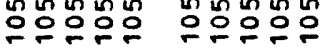

ตีกักับ

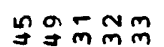

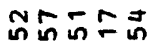

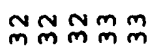

กิระกั่

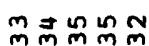

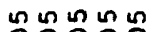

กㄴำ

ก는

ถูก๊ำกำ ำก끄ำ

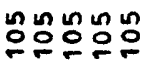
으응ㅇ으으

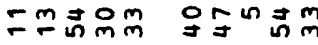

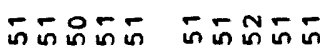

ニละ๊

${ }^{\infty}=m-F$

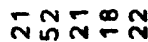

ษำํำำ

gogos

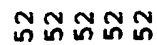

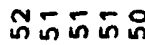

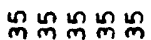

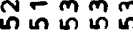

品点品点品
命感点品品

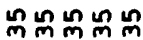

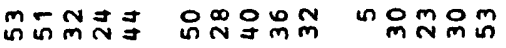

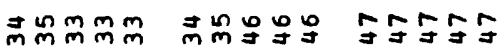

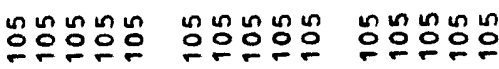

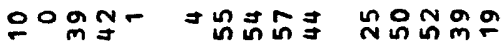

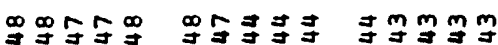

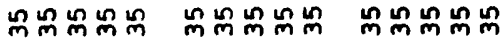

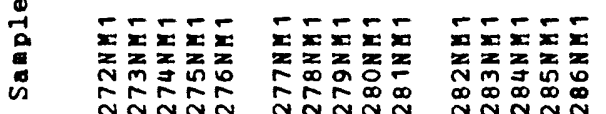

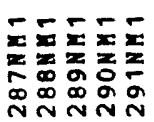

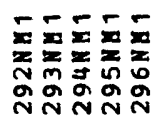

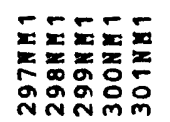

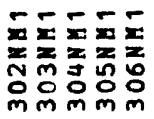

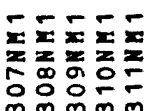

$\bar{x} \bar{x} \bar{x} \bar{x}$ $x \geq x$ 긍 S. 


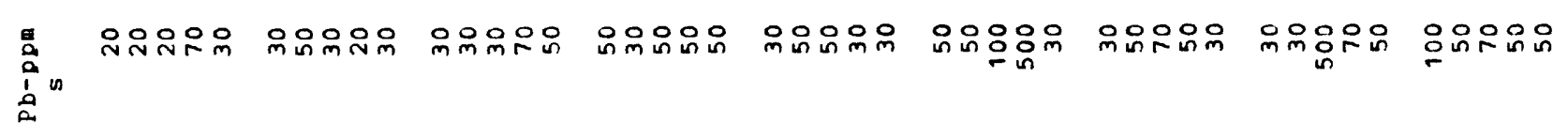
a
$\vdots$
$\vdots$
$z$

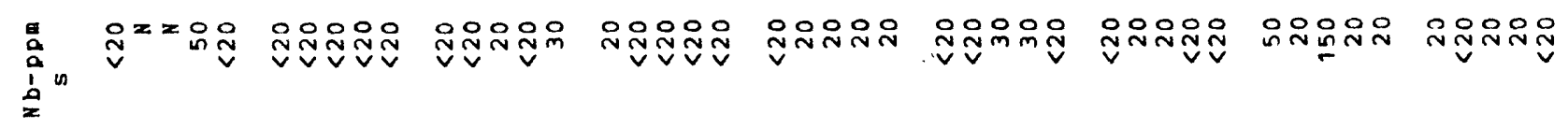

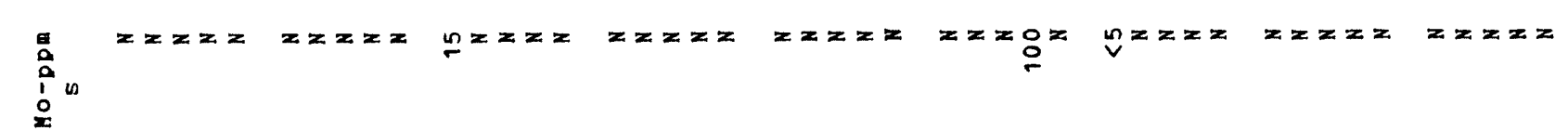

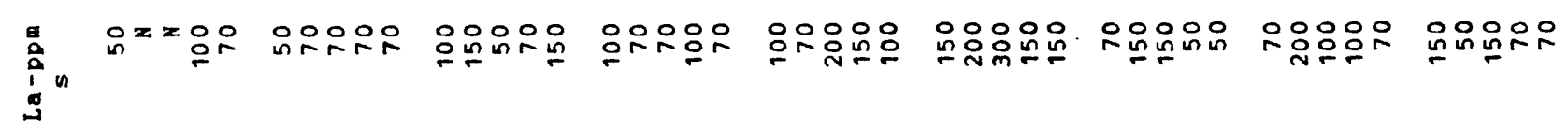

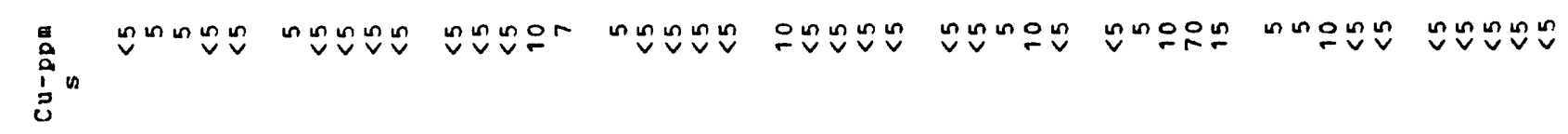

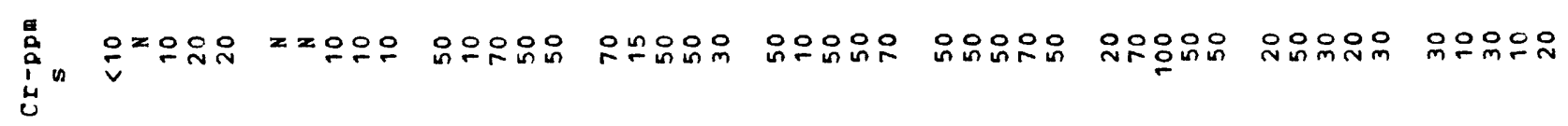

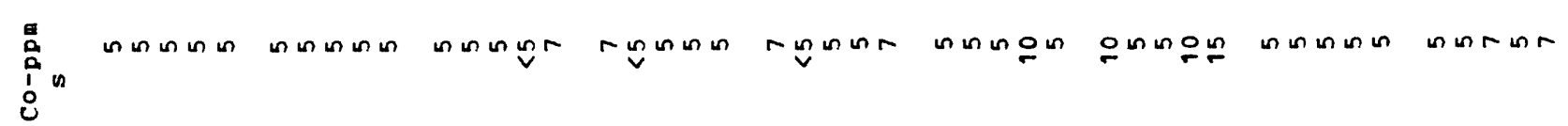

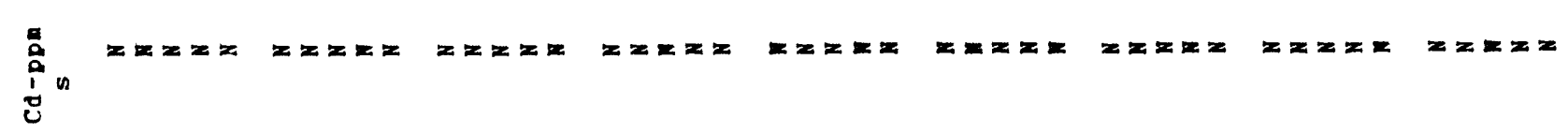

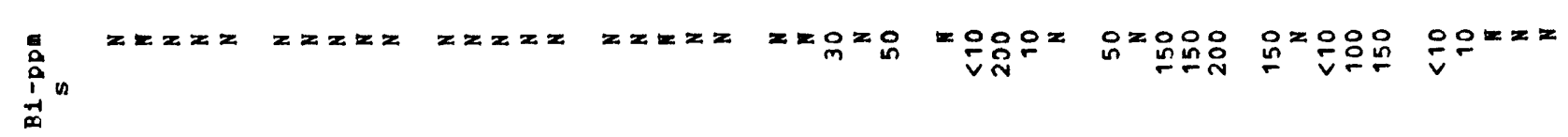
厽

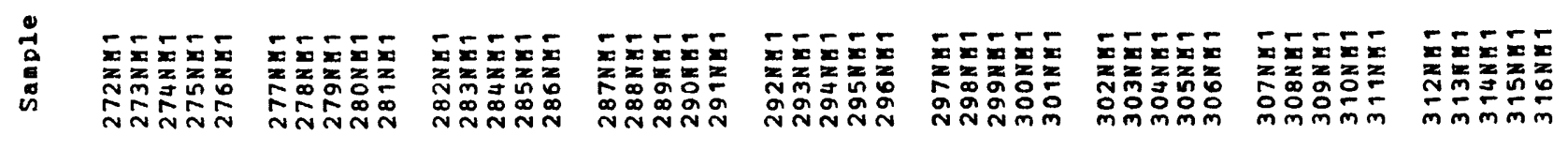


$\overbrace{0}^{\infty}$

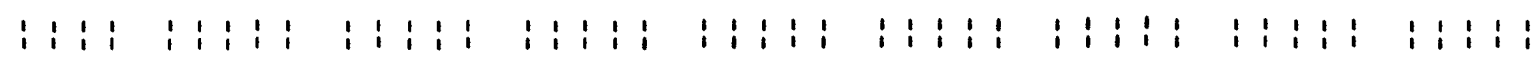

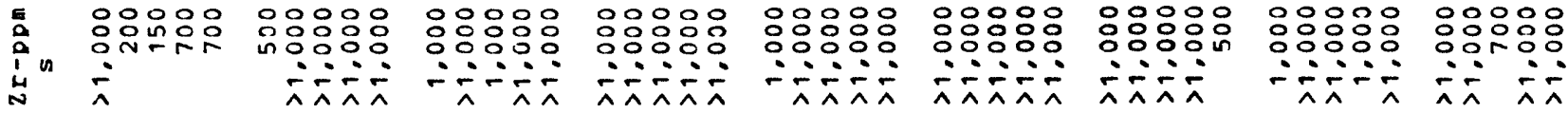

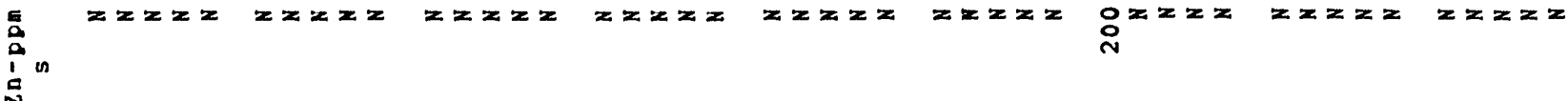

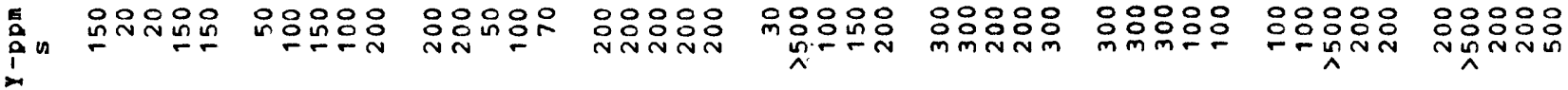

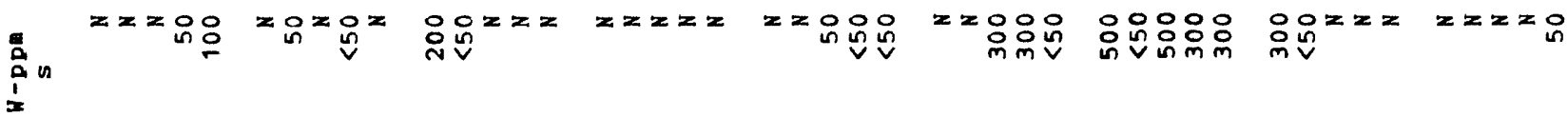

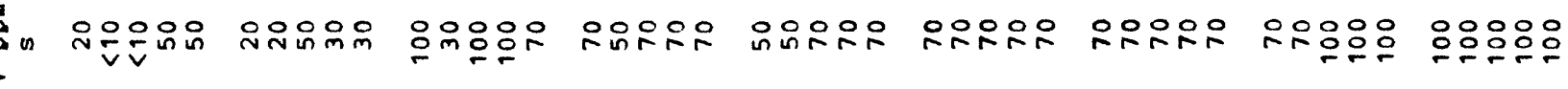

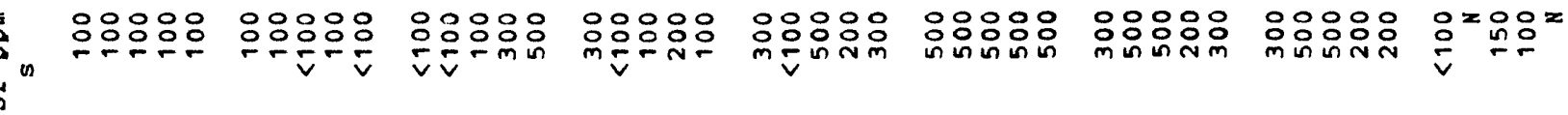

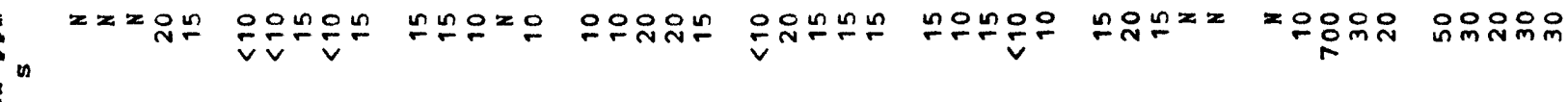
in

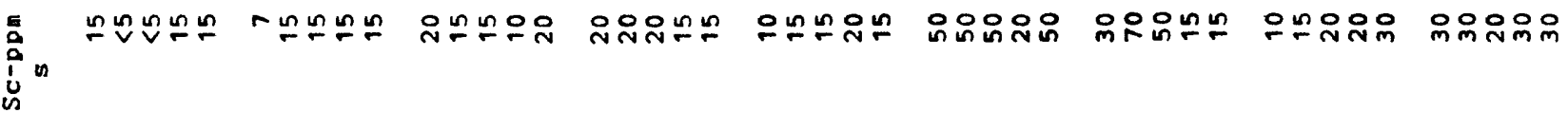

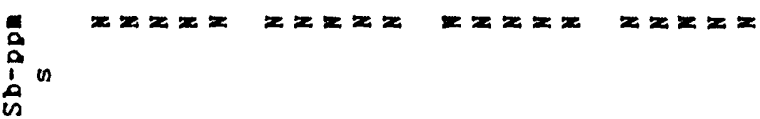

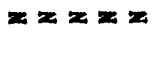

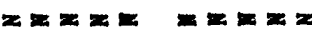

$z=2 x$

$z=2 x=2$ 窝"

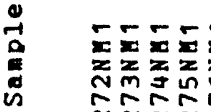

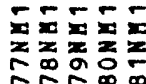

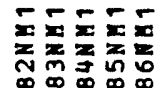

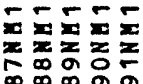

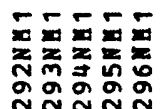

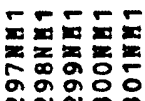

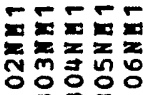

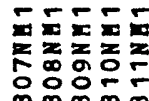

Ex=5

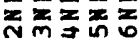
N

NNiN이

- 


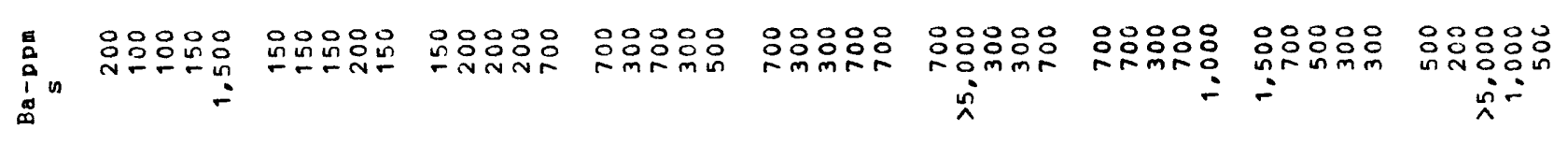

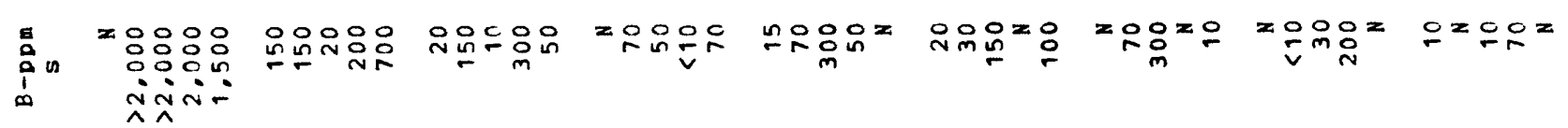

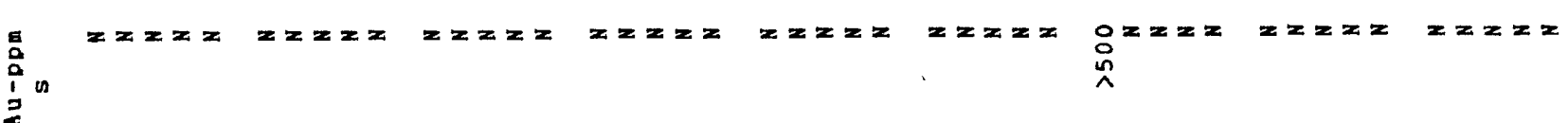

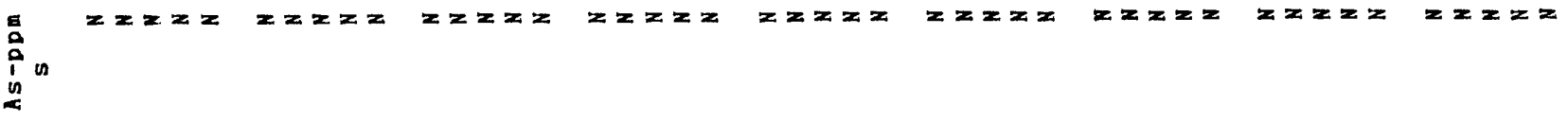

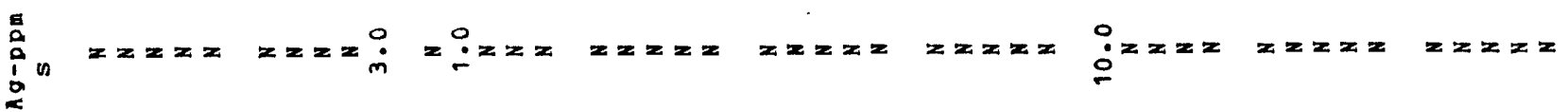

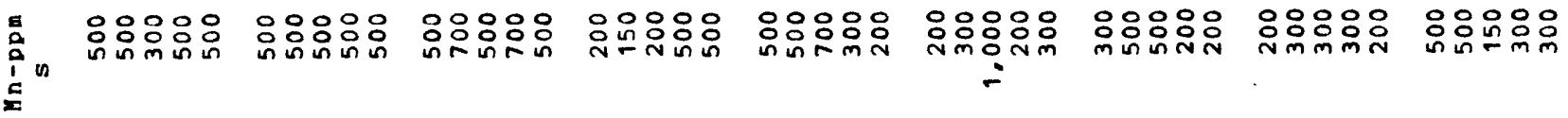
茜 䓪

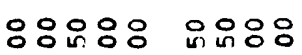
in-ni $\ddot{n} \dot{n}$

응응용요

응응ㅇㅇㅇ응

옹용ㅇㅇㅇㅇㅇ

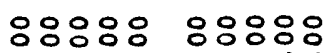

옹응응요

옹용ㅇㅇㅇ

$\underset{\omega}{\infty}$

은응웅ㅇ 웅으응

$\stackrel{+}{u}$
$\vdots$
$\vdots$
0 ํㅜㄴ

ำำำ

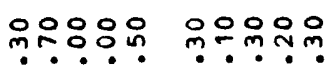

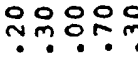

응ㅇㅇ웅

inmor rón

$\dot{\sim} \dot{m} \dot{m} \dot{n}$

$\dot{0}$
$\vdots$
$\vdots$
0

우융ㅇㅇㅇ 응응응 $\because \because \because \because \because \dot{m}$

0
0
0
-1
0
0
0
-1
0
0
0
4
4
0
0

กับกั

a

뜬류롤

응웅웅유뭉

-ni-

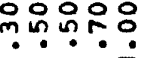

눈응우운

운옹ㅇㅇㅇㅇ은

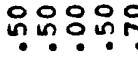

웁웅ㅇㅇㅇㅇㅇ

늉용ㅇ

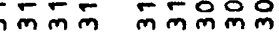

으ํํㅝㅁํํ

กำำ ูู

mogn

웃ํํํำ

응이임오

ํํㅇํํㅇํㅇ융ㅇํㅇ

ํㅗㅇ드유용으

응ㅇㅇ으응응

능응유응응

농용ํㅇ응응

nูบำ

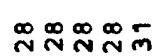

ㅇํㄹㄹำ

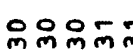

กู้อี้ี

กท กท

ก

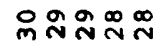

동응ํㅇㅇํㅇํํ

응등융ㅇㅇ응

ทียกำกำ

으으으으응

Nㅡㄴ

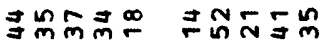

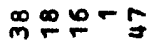

$\stackrel{9}{\Rightarrow} 0^{\circ} \circ 0$

mีㅗํำ

タษฐすษ

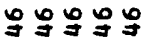

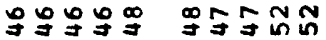

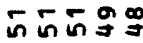

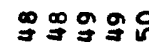

은유은영

ํํํํํํํำ

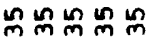

nnm nnm

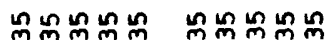

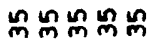

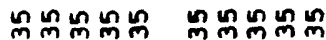

월웡워

n.

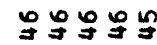

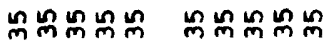

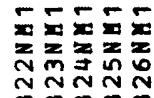

NㅜNNำ

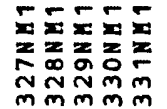

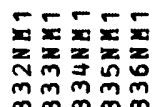

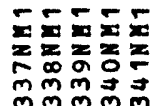

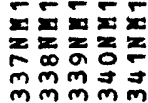

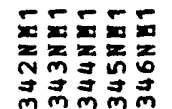

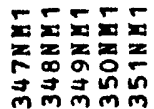

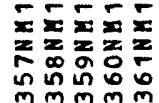




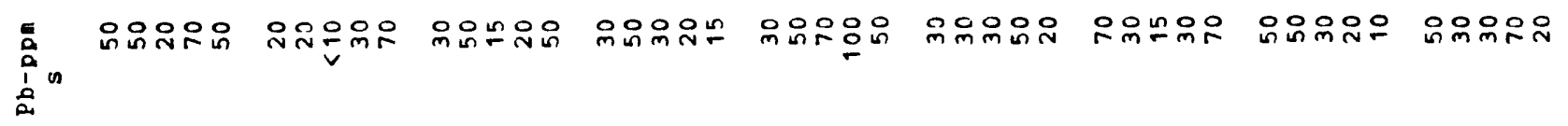

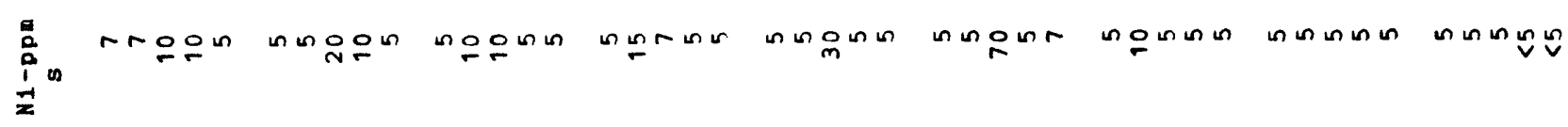

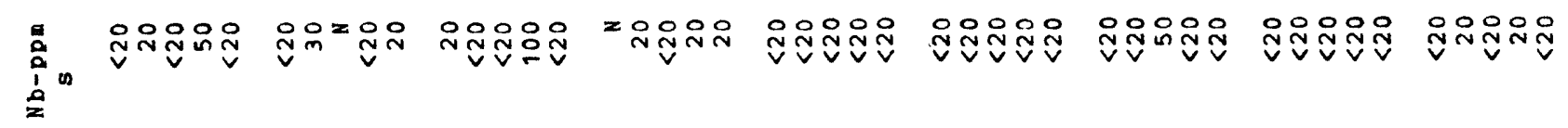

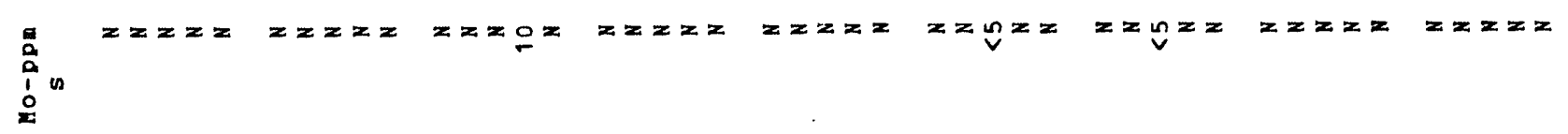

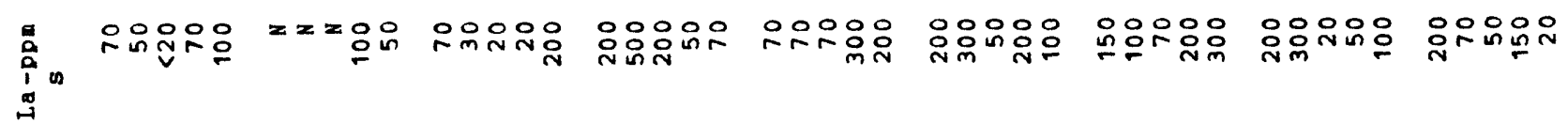

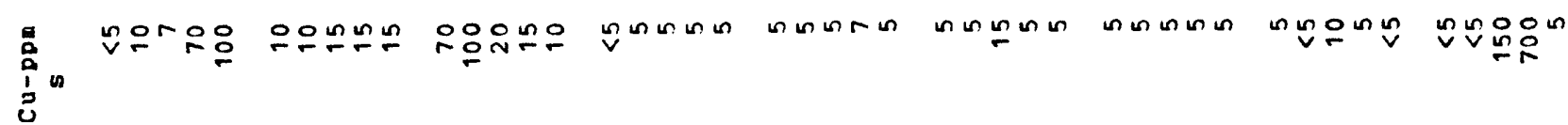

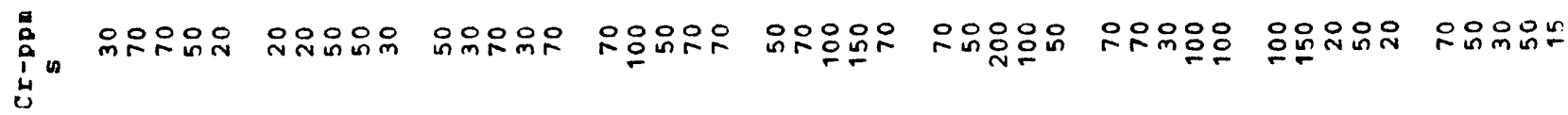

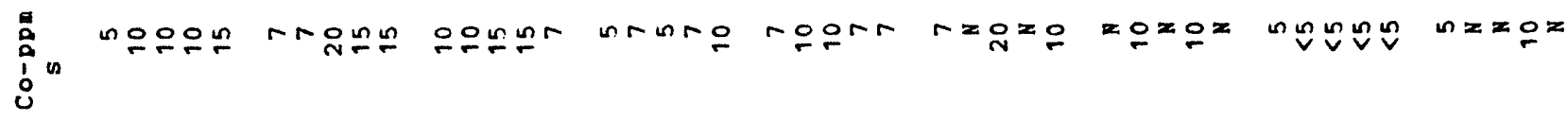

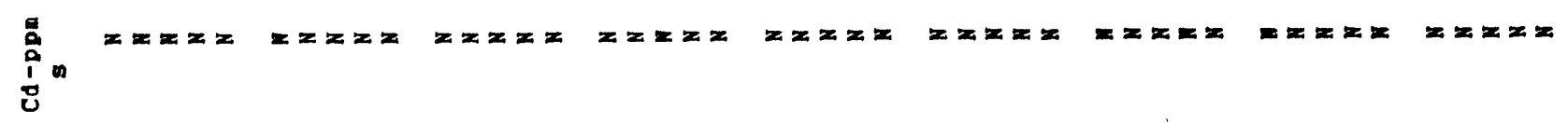

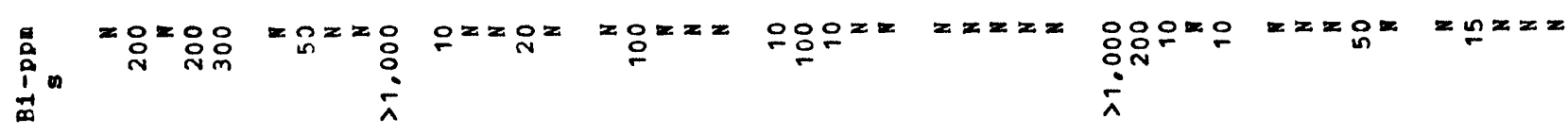
強

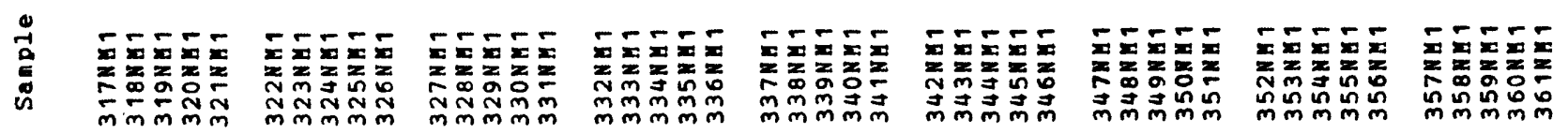


in

政

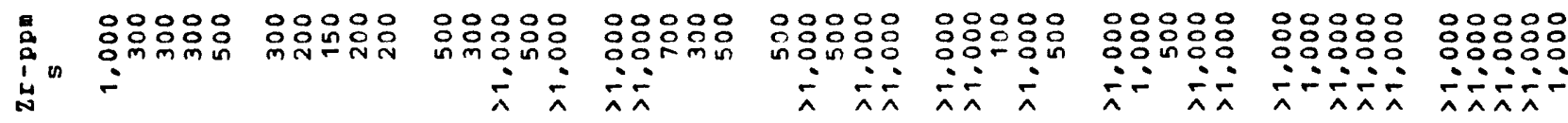

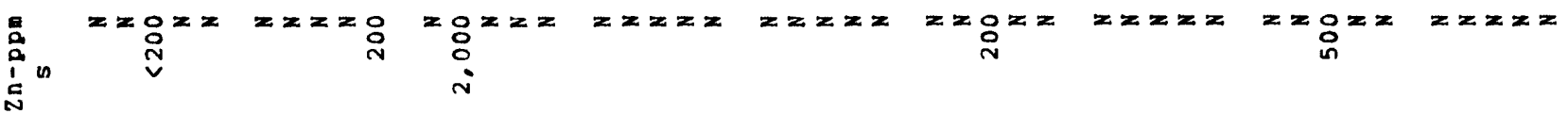

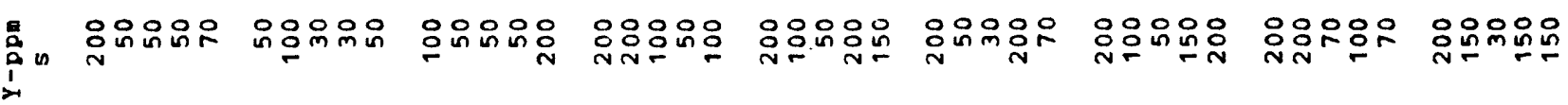

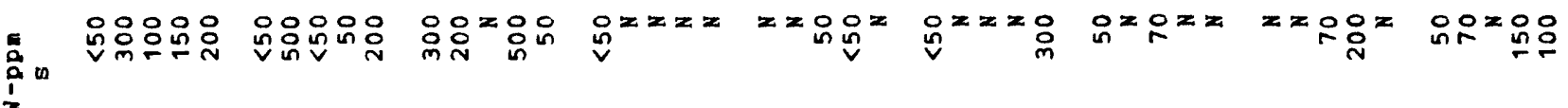

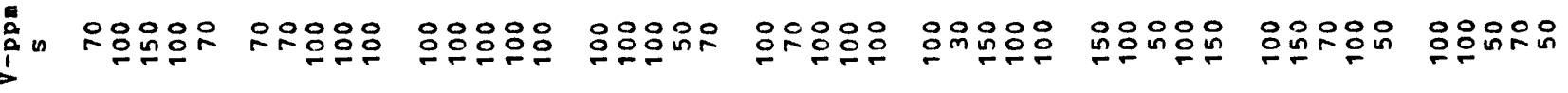

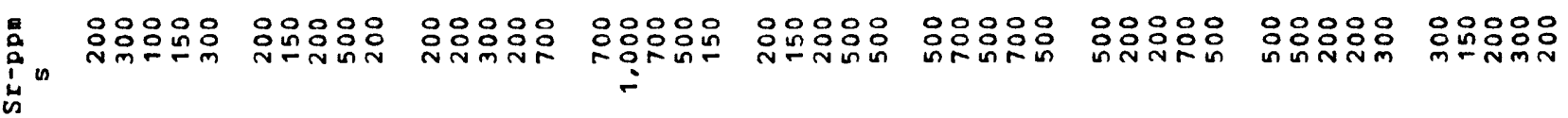

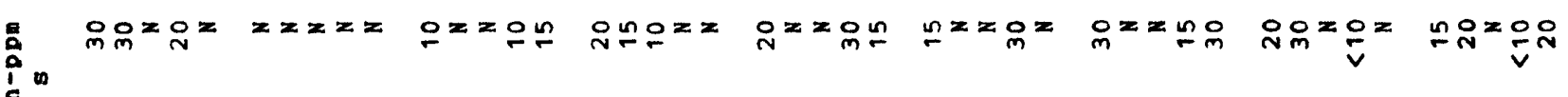

占

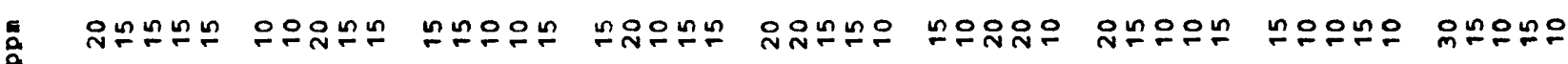
is

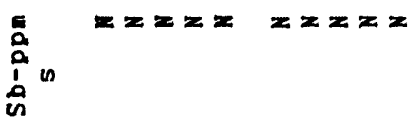

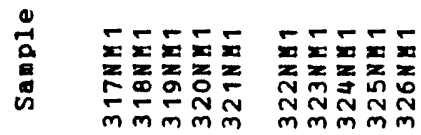

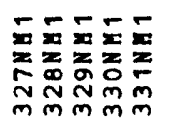

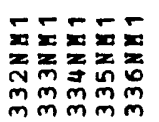

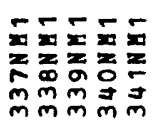

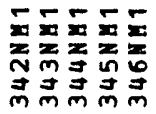

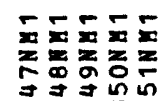

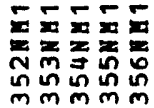

EEFE

홍흐응

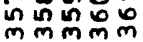




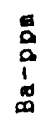

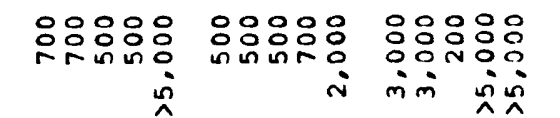

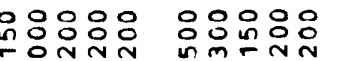
in

응용

응응ㅇㅇㅇ

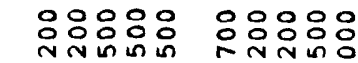

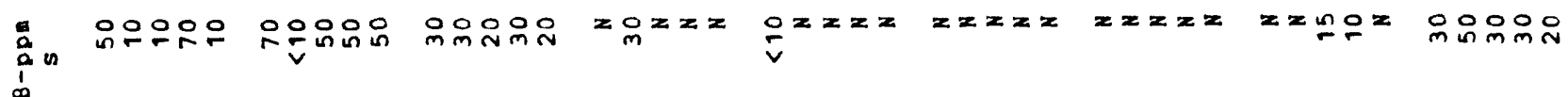
$\varliminf_{2}^{0}$

$z=x z$

$x=x \geq$

$z z z z$

$z x=2$

$z z z z$

$z x z x=$

$z z z z x \quad z z z x z \quad z z z z x$

$z x z$

$=$

$z=2$

$x z x z$

$z z z z$

$z z z z$

$x=2 x=$

$z z z z$

$x z x z$

$x z x z$

in $n$

$\sum_{\substack{0 \\ 0}}^{1}$

$z x z z x \quad z z z z z$

$z x z z=$

$z=z z$

$z z z z$

$x z z x$

$z x z$

$z x=z$

$x=x \geq$

i

옹요웅

00000

00000

00000

옹ㅇㅇㅇㅇ

옹옹응

응ㅇㅇ

읏윰융유 웅유윰융

co

0000000000

00000

00000

ก::ㅇ:

0.0000

웅웅

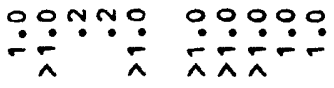

ind

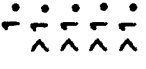

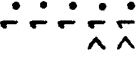

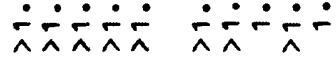

$\therefore \div$

-

ते

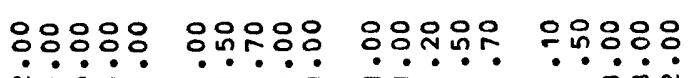

$\dot{m} \dot{m} \dot{v}$

응ㅇㅇㅇㅇㅇ 용ㅇㅇ응

응ㅇㅇㅇㅇㅇㅇ

응응ㅇㅇㅇ

mंरिंm

$\dot{m} \dot{m} \dot{n}$

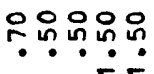

نं

vinim

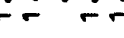

NNmin

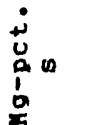

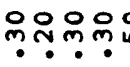

o0000

on 000

00000

웅ㅇㅇ

으은유오

유읐융유음

우웅우

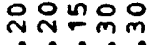

莒冏

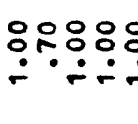

융은응용

은요응응

응응은은으

웅

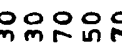

응응으운 윤응오운

웅ㅇㅇㅇㅇㅛ

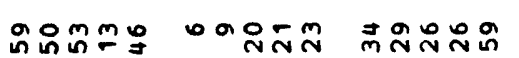

율ำ

ํำ

mim

$\because \div$

$\because \because \div$

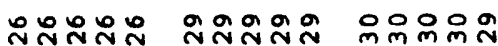

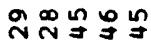

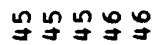

웡요

mํำㄴำ

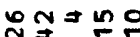

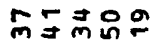

นกํํํํํํํำ

ㄴํㅇํํํํํำ

등응으응응

ํํㅇํํㅇํㅇํำ

ํํㅇํํㅇํํㅇํㅇ

舟里品용

ㅇำำกำ

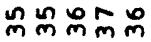

유유웅 우웅응

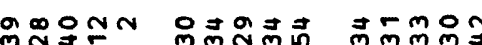

를ํำ

ลี่

눙요

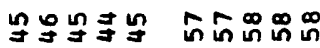

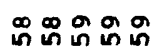

ํํำ ํํำ

กี่

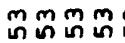

ํํㅇํํㅇํㅇำ

นุำํํํํํำ

드응으응으

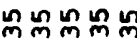

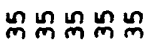

m $m$ m $m$

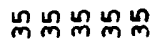

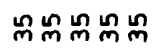

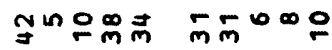

눙유ำำ

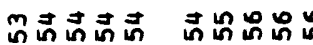

은은의

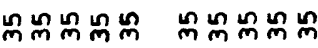

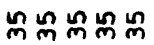

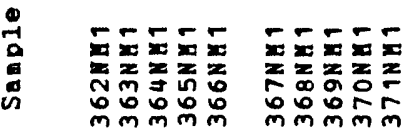

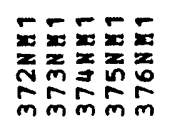

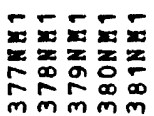

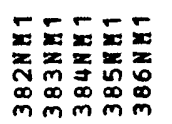

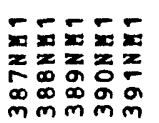

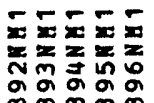

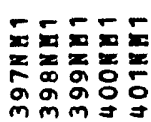

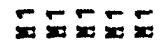

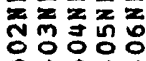




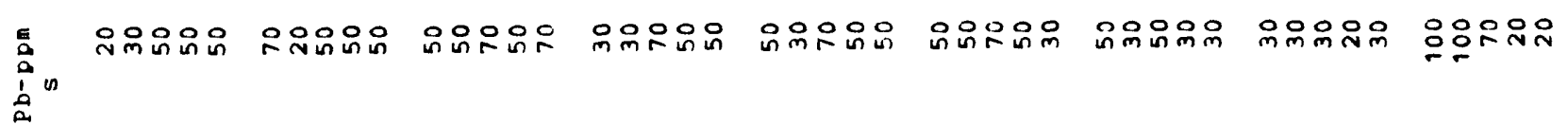

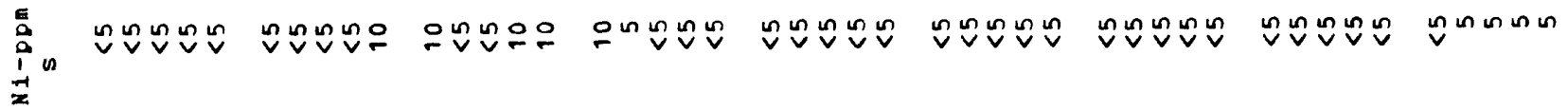

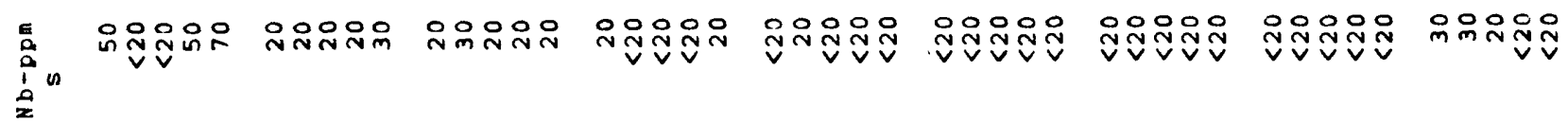

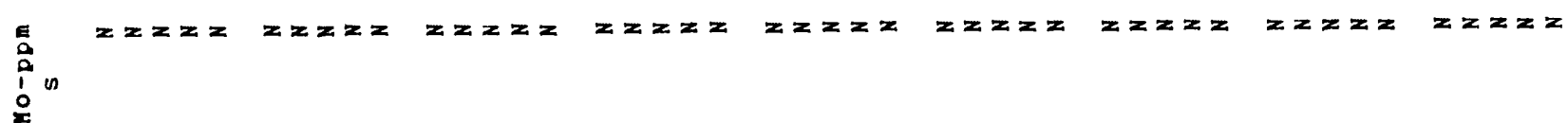

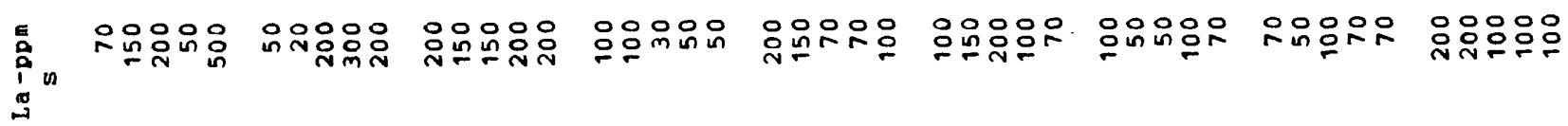

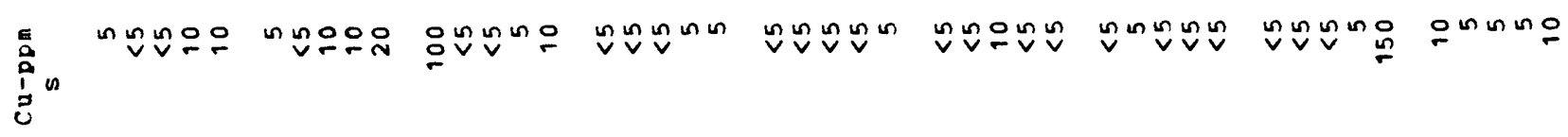

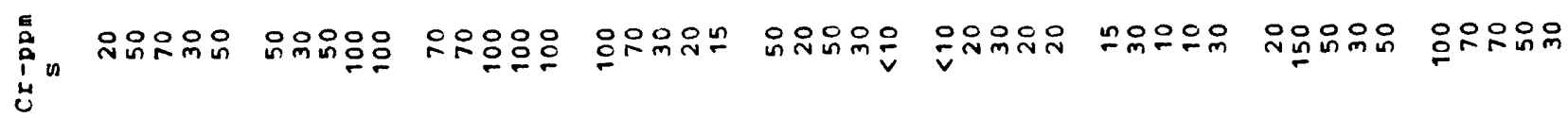

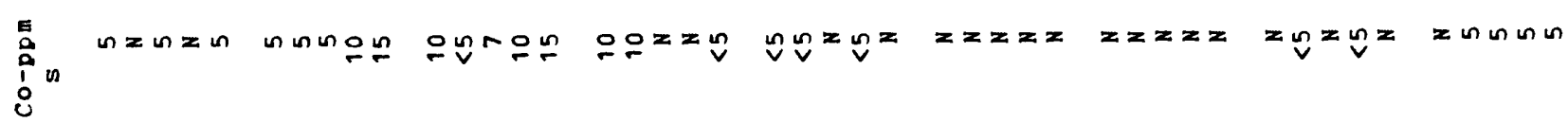

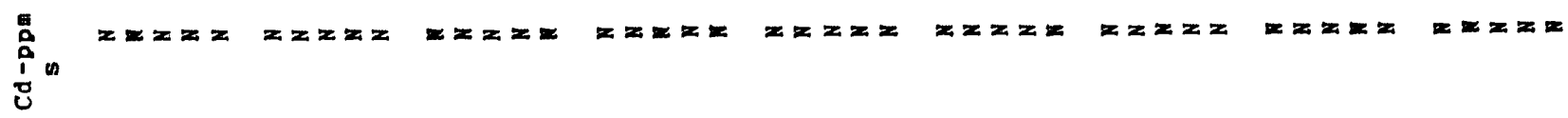

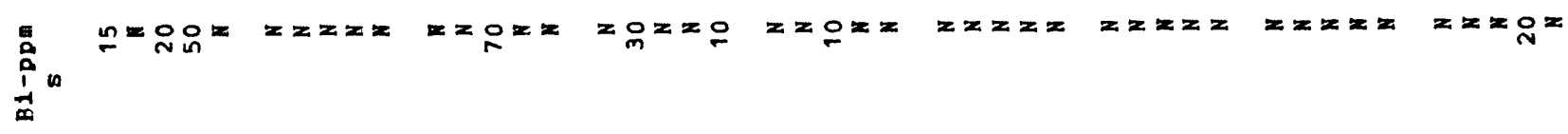
台

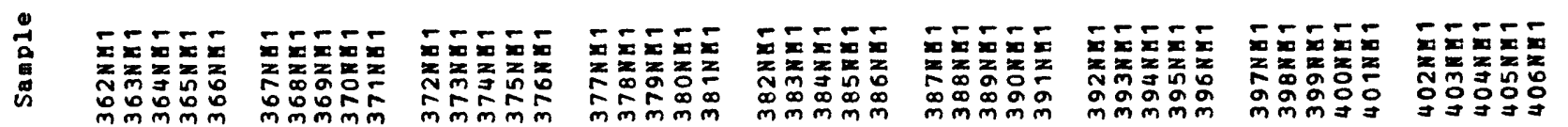




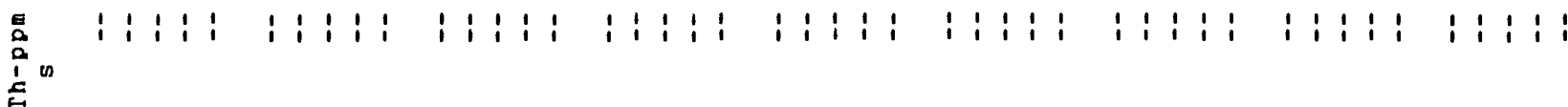

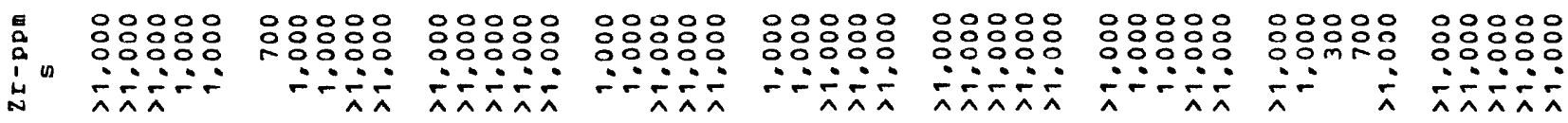

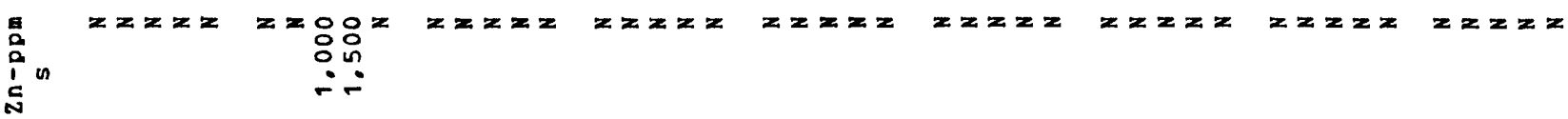

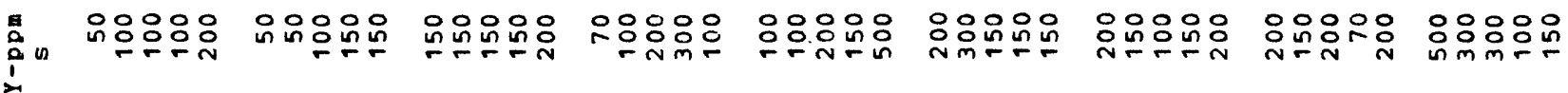

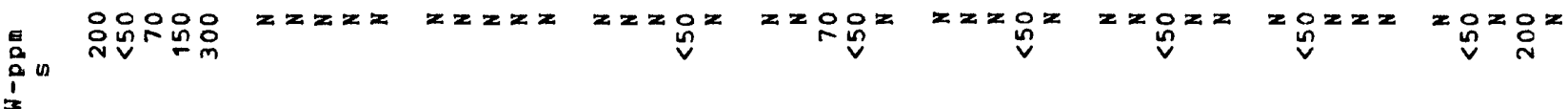

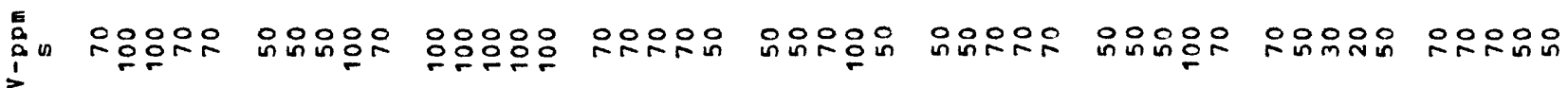

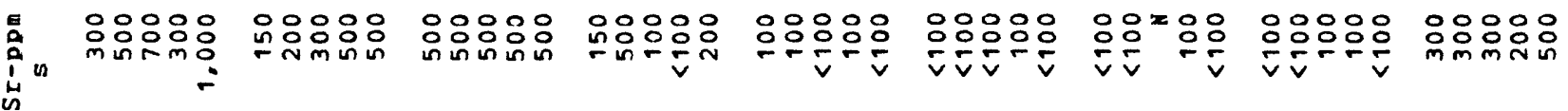

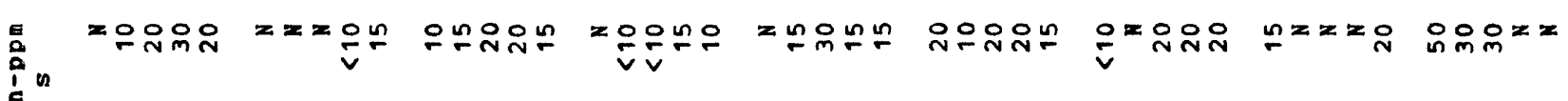

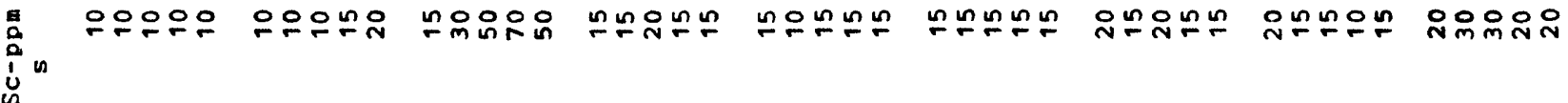
$\dot{m}$

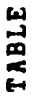
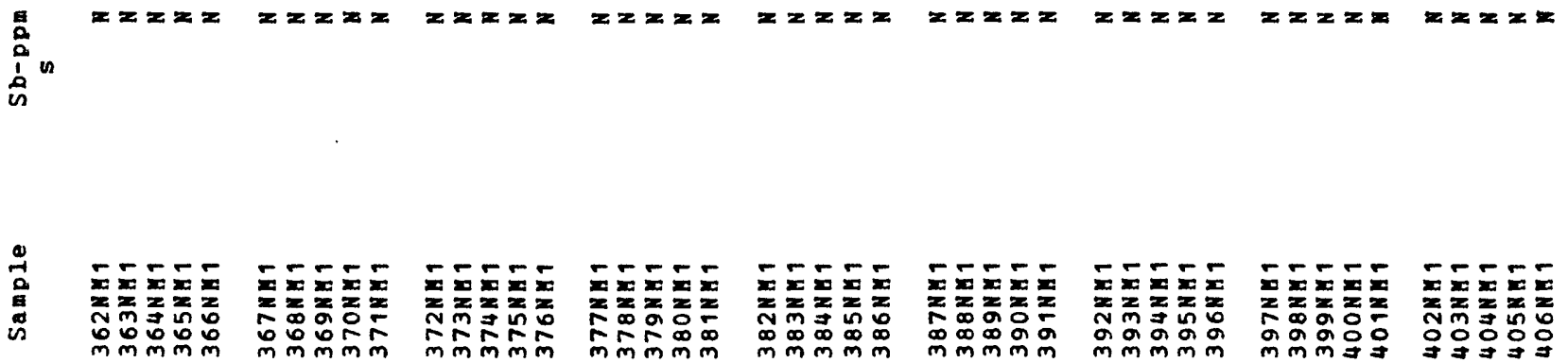


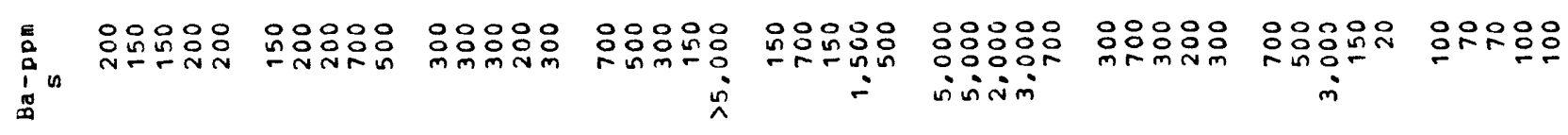

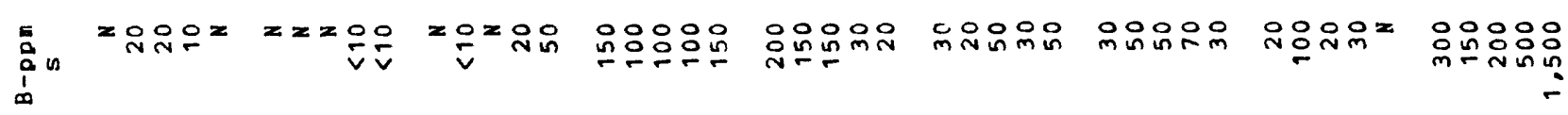

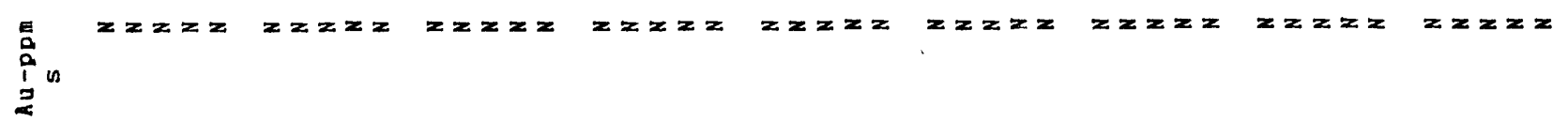

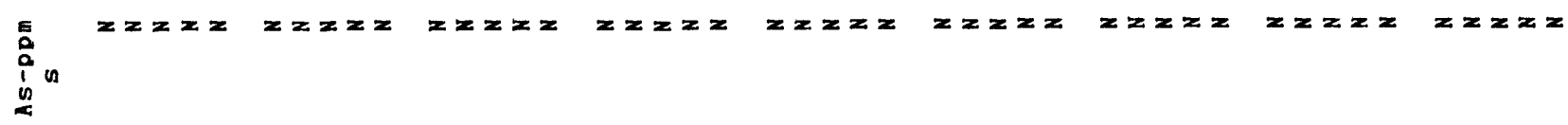

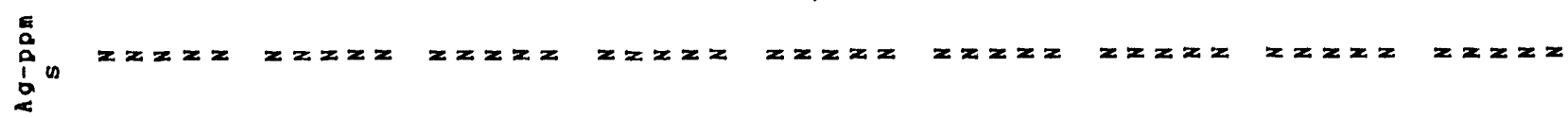

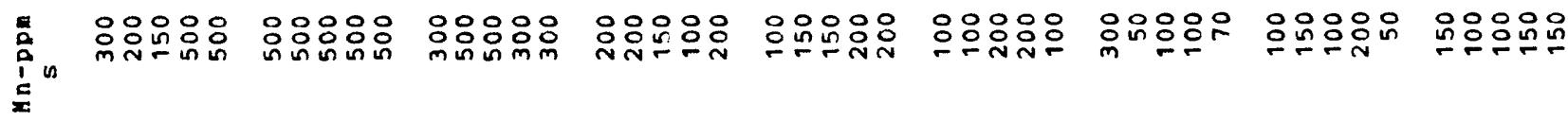

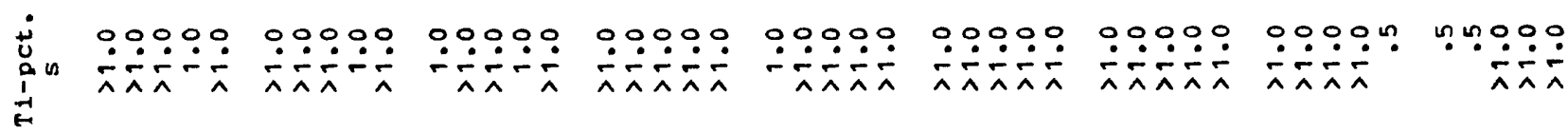

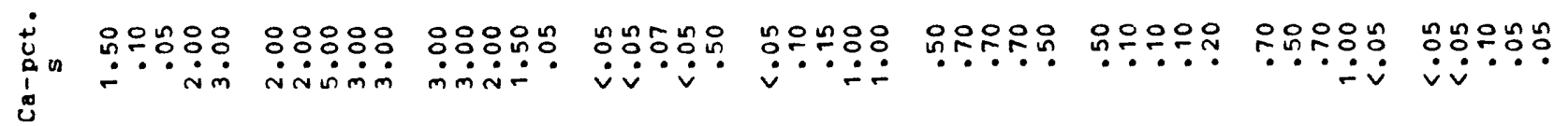

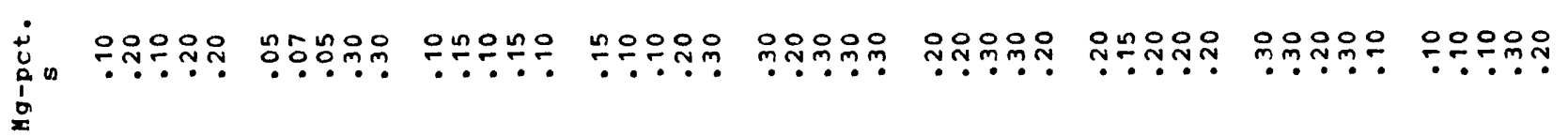

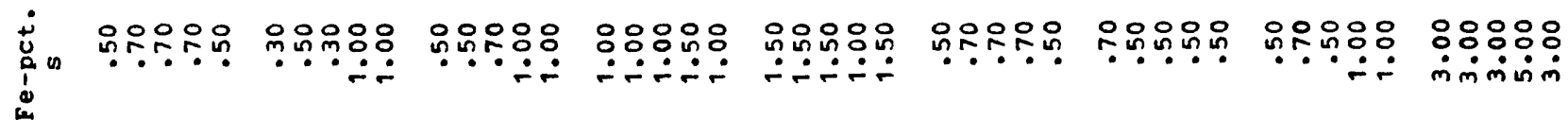
苟

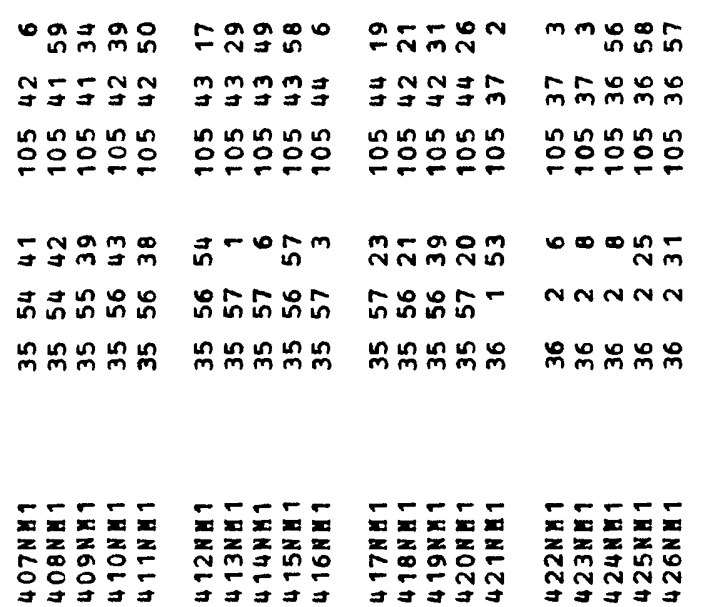

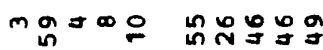

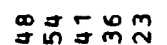
กับำำ

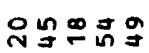

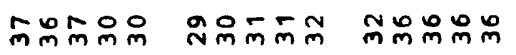

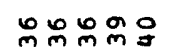
àmoñ

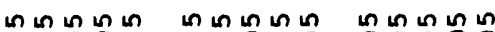

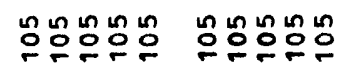

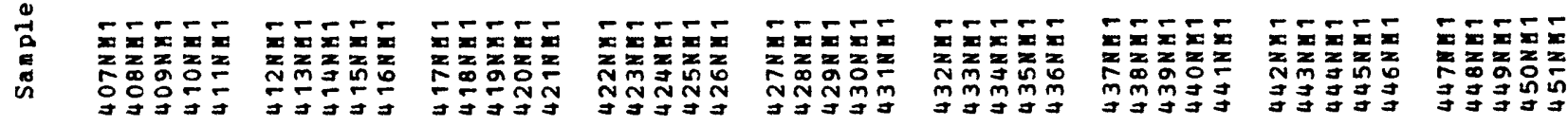




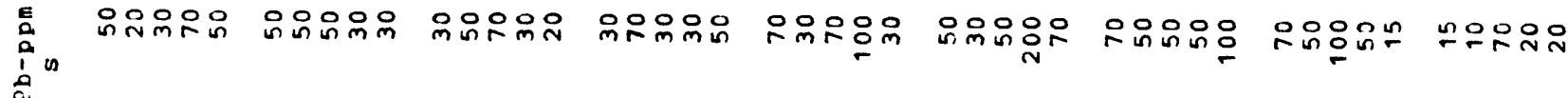

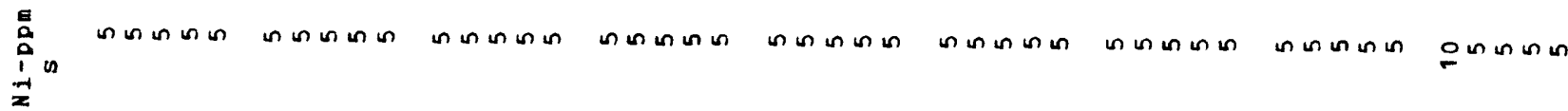

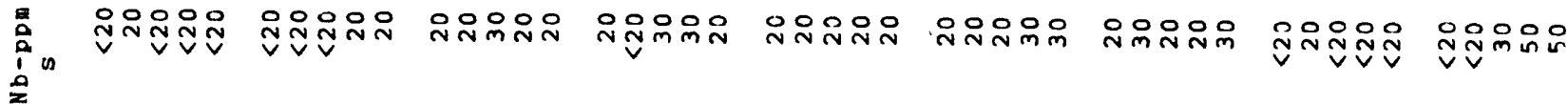

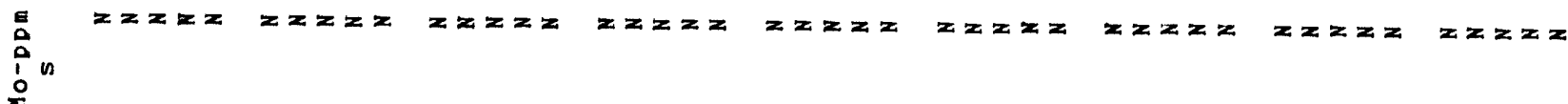

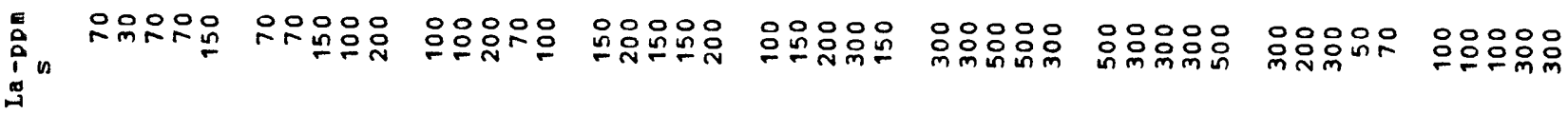
E
$\vdots$
$\vdots$
$己$

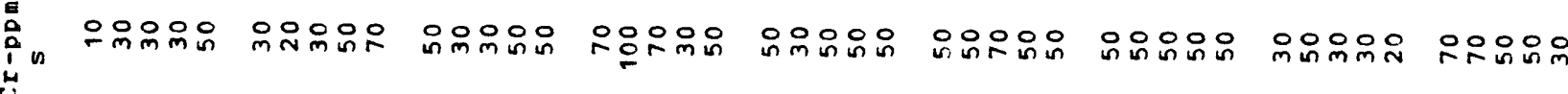

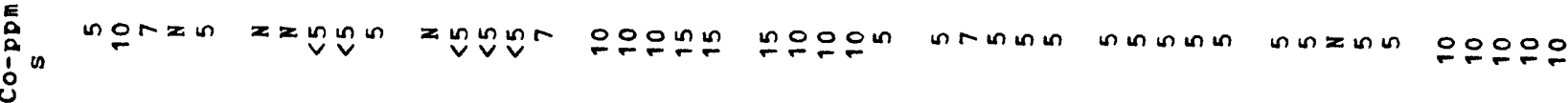

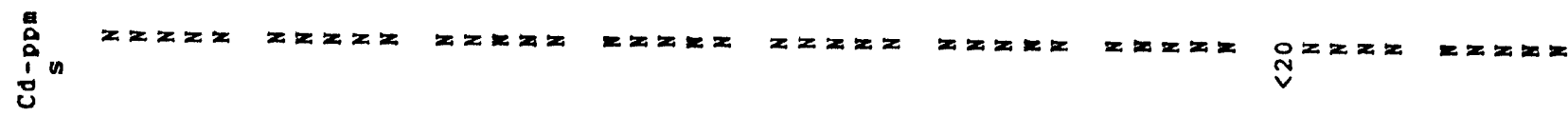

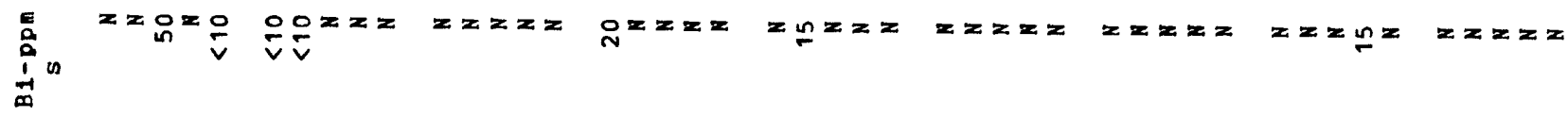
虫n

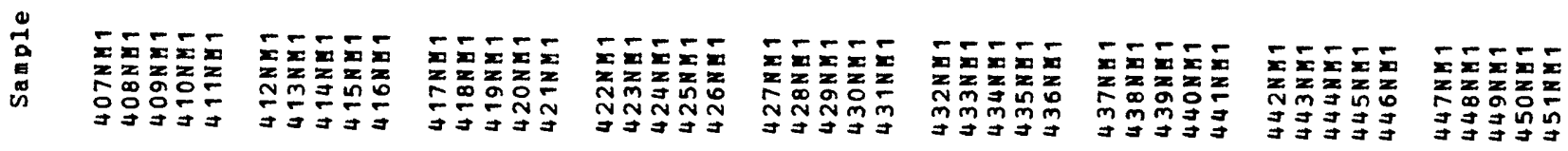




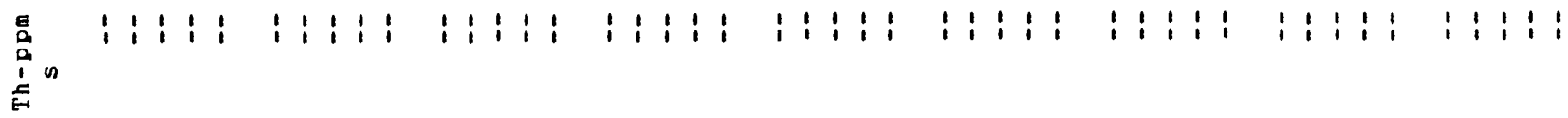

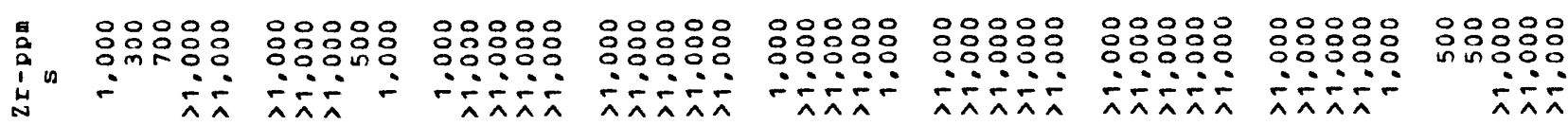

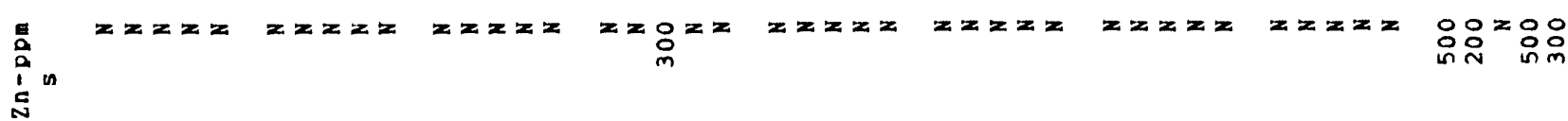

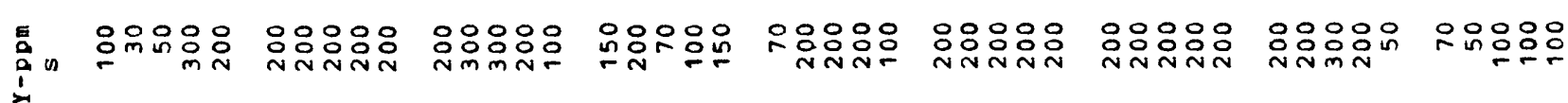
品

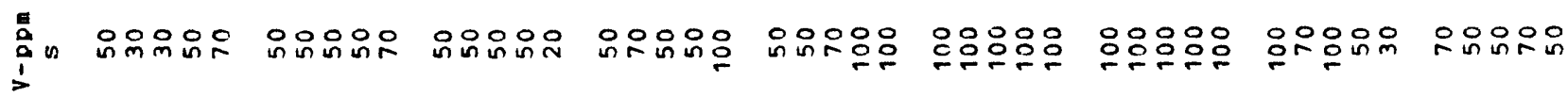

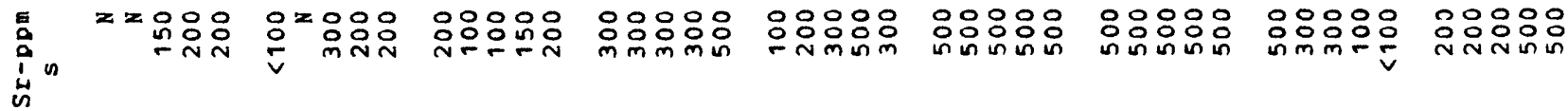

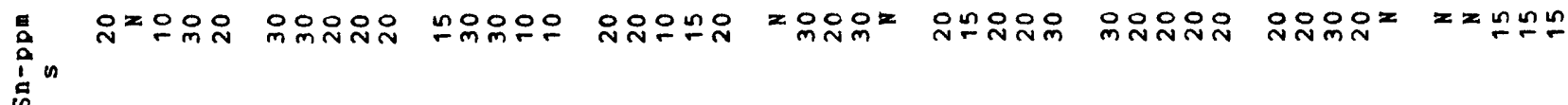
约

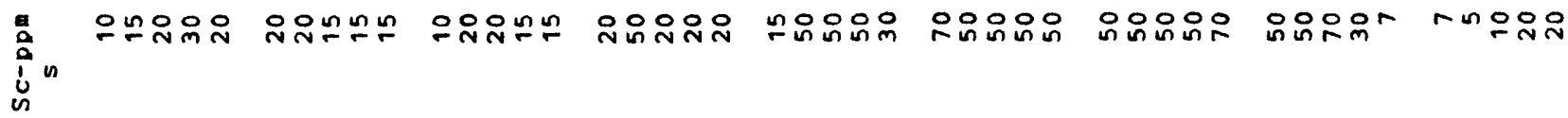
$\dot{m}$

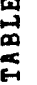

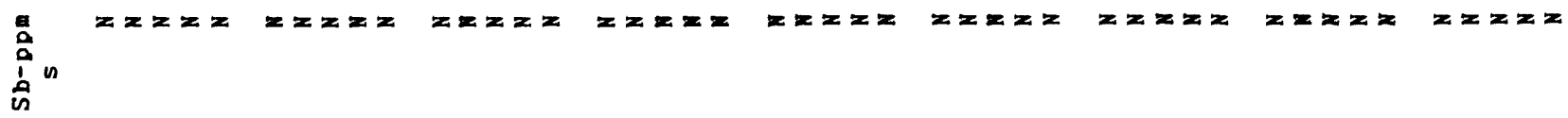

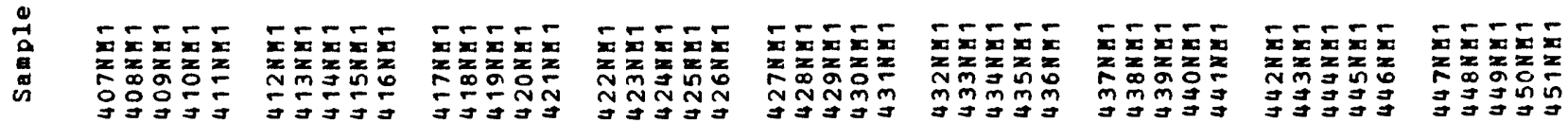




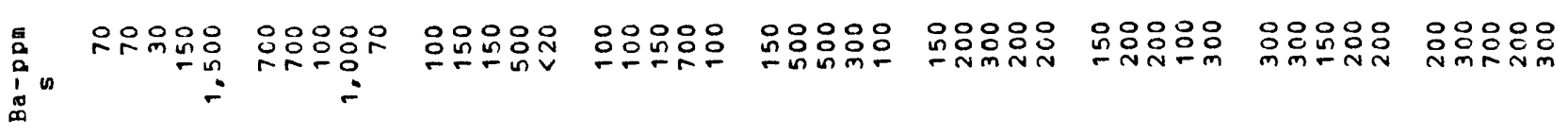

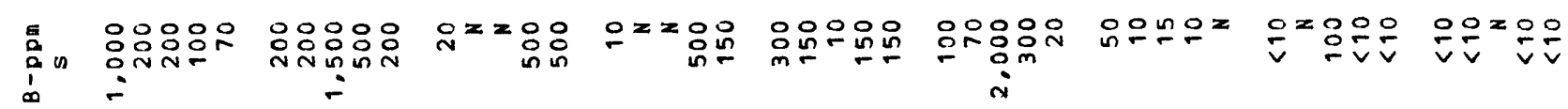

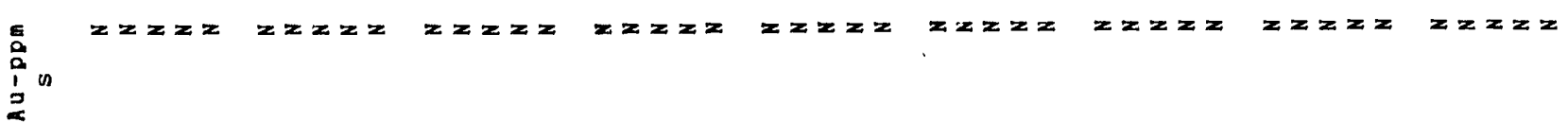

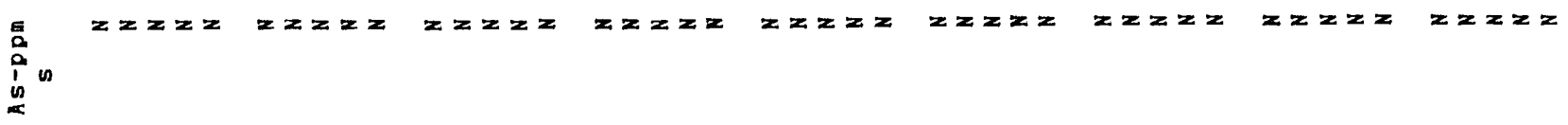

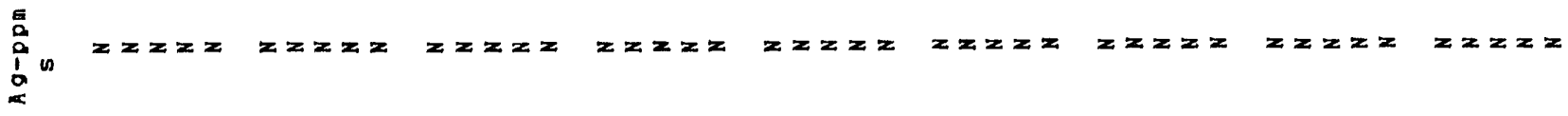
ปั

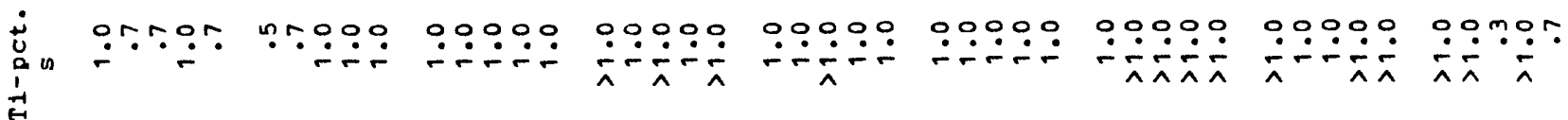

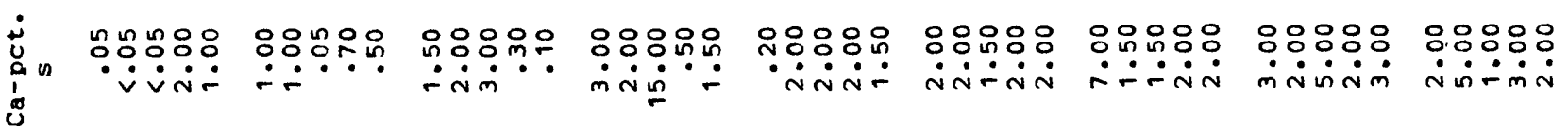

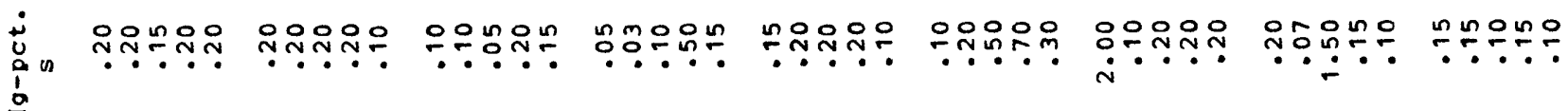

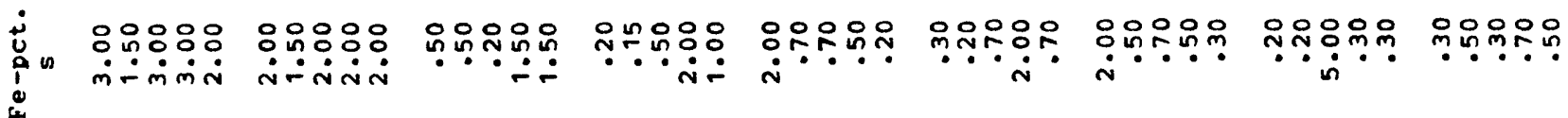
至

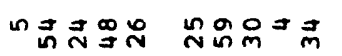

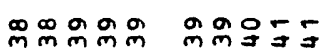

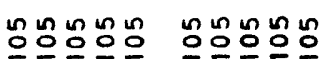

$m \backsim \pm 0 \backsim$

오ํㅗㅗ은

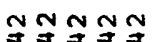
고ำ

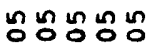

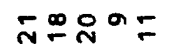
ำกำ 可寻寻寻寻 寻寻寻寻寻 घ코ำ

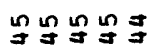
ninn in กำนnน ํํㅇํํำกำำำ 으으응ㅇㅇ $\stackrel{+}{\circ}$

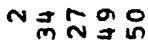

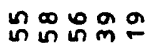
招寻寻孚色

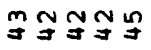

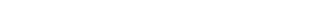

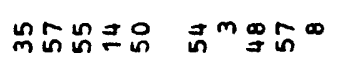

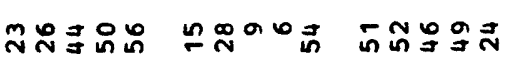
- N ह

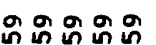
oor in

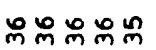

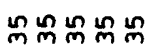




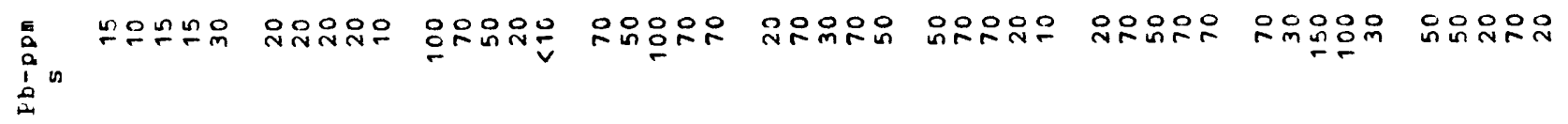

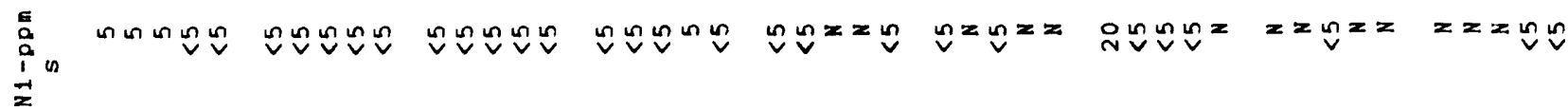

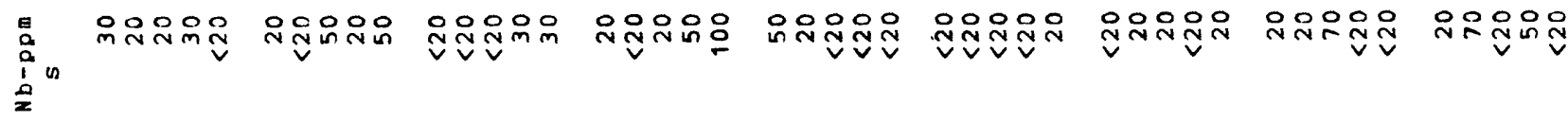

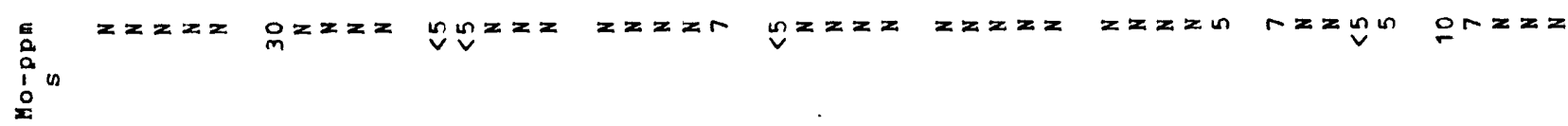

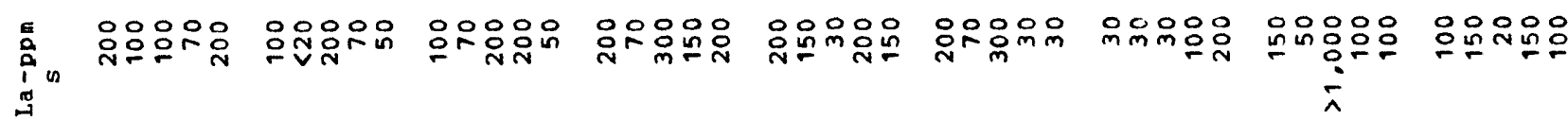
E $\mathrm{u}^{3}$

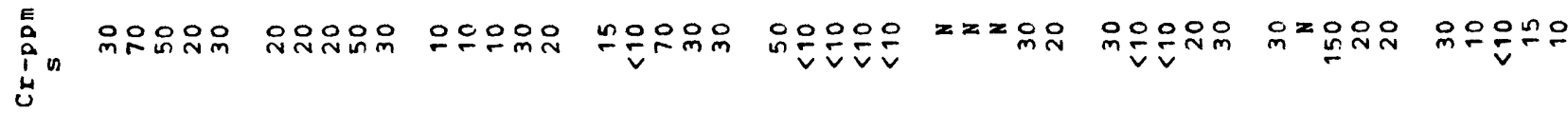

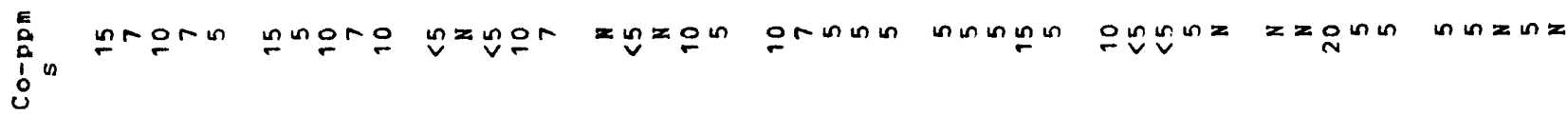

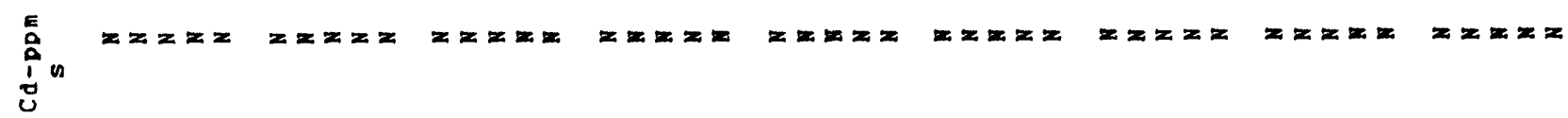

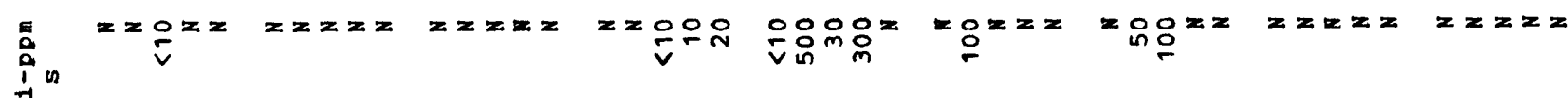
$\dot{m}$

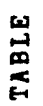
in

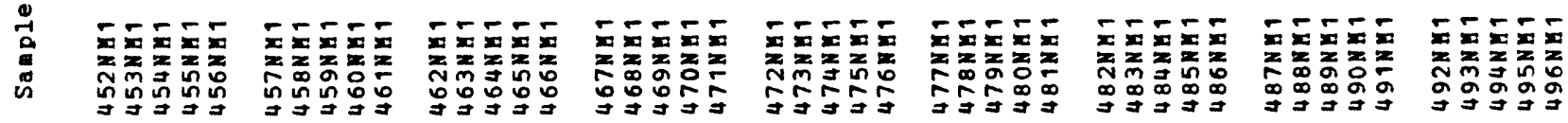




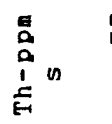

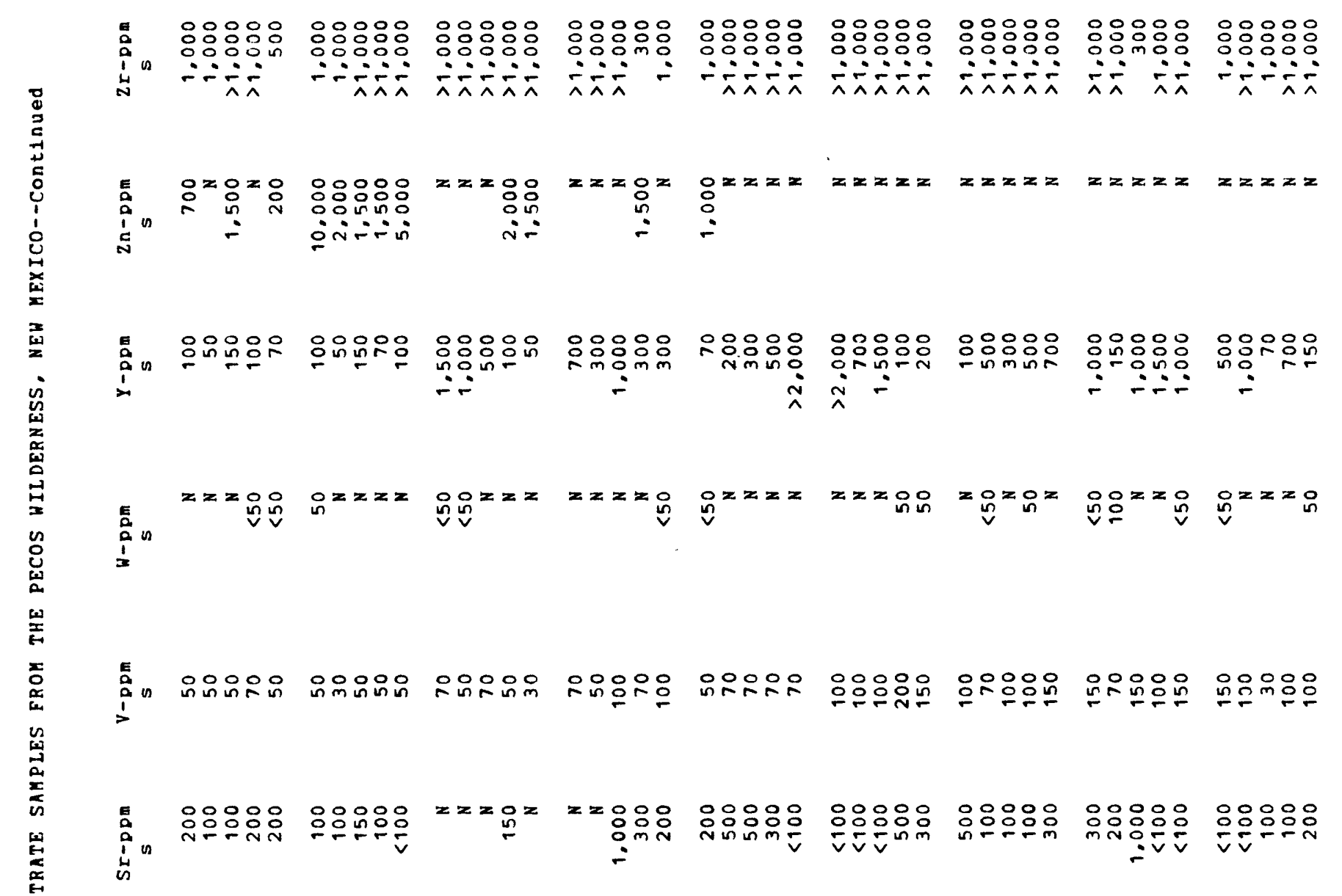

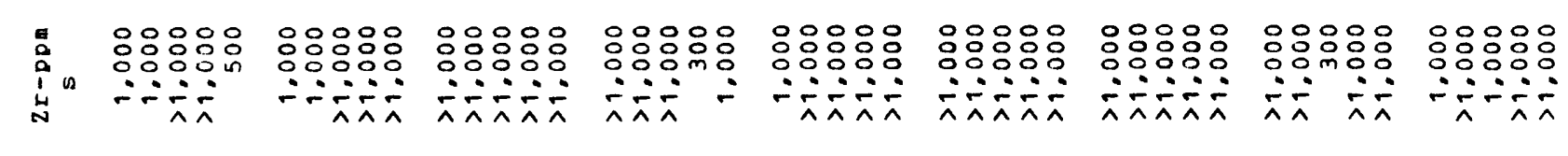

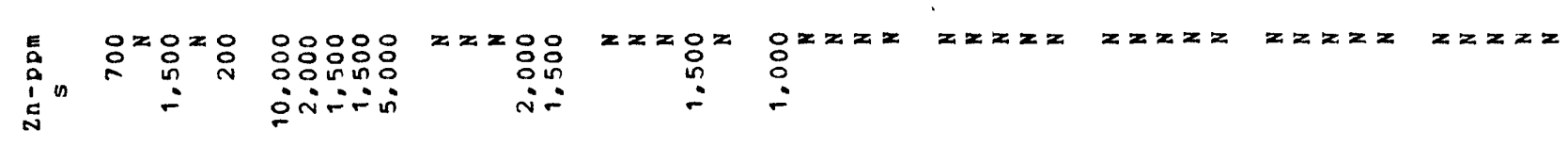

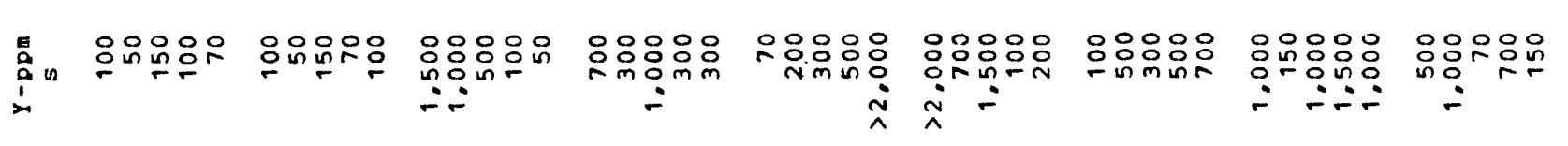

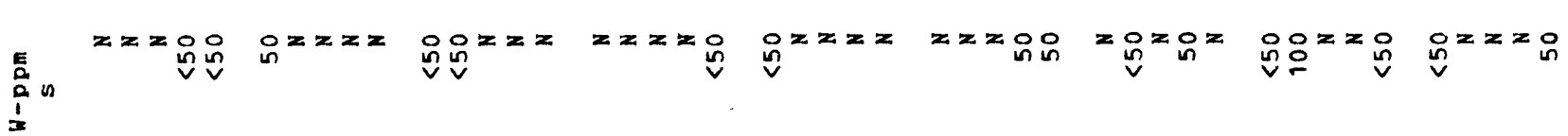

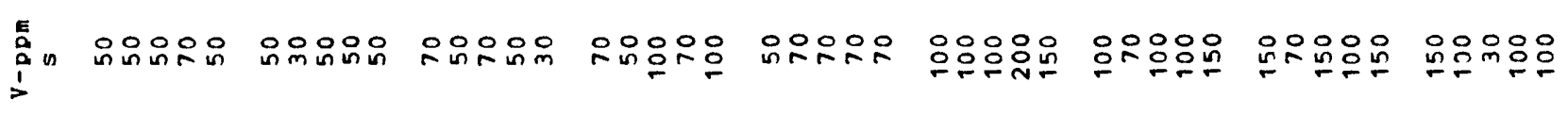

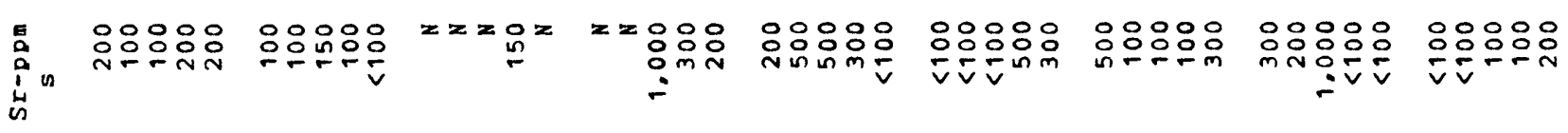

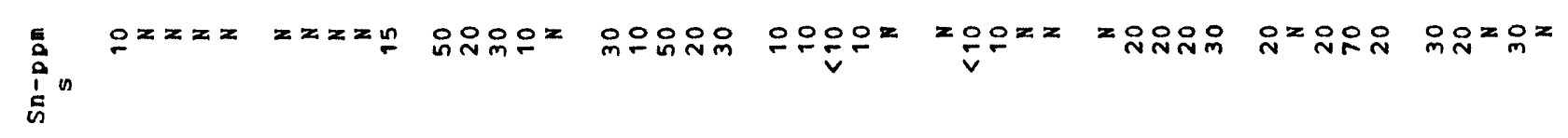
옹

ca

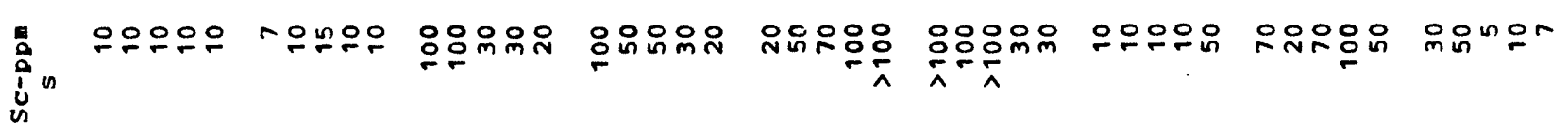

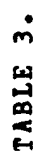

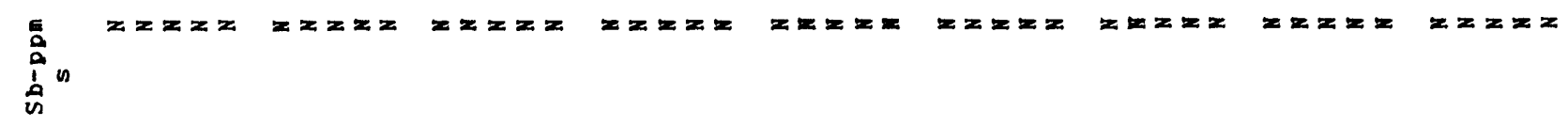

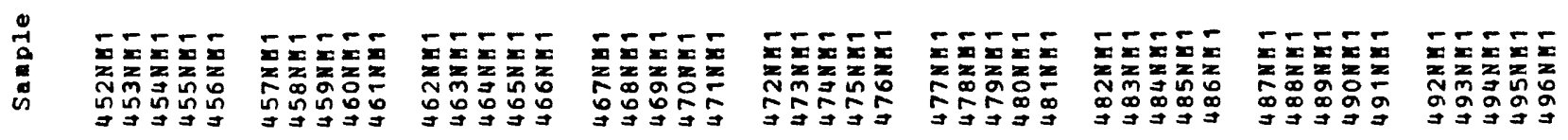


高

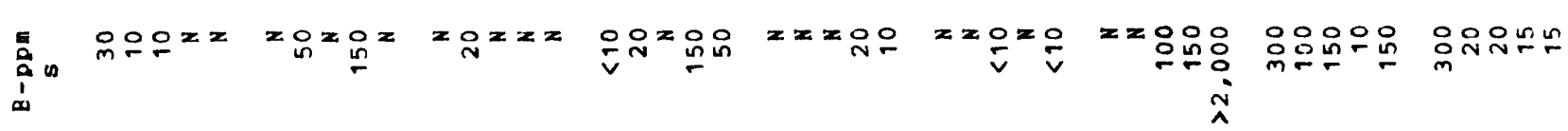

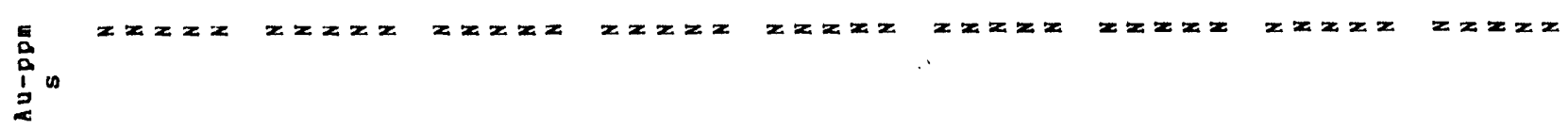

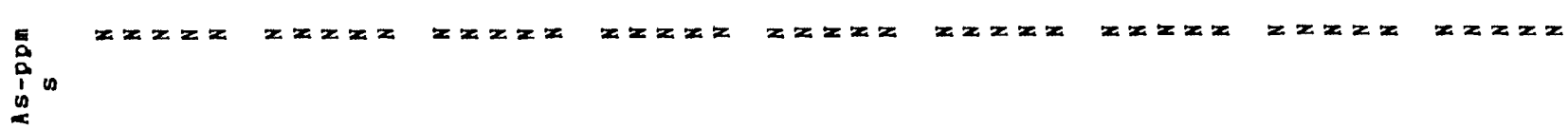

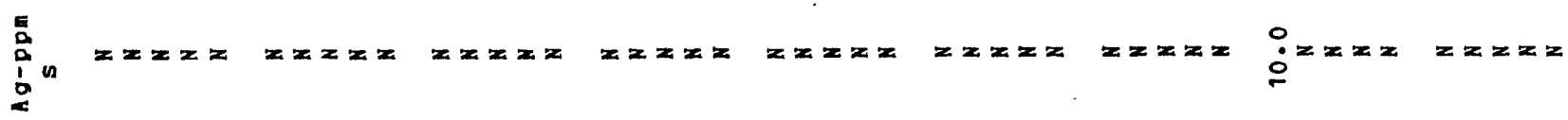

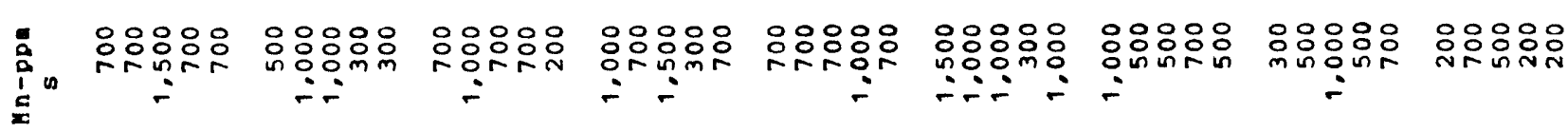

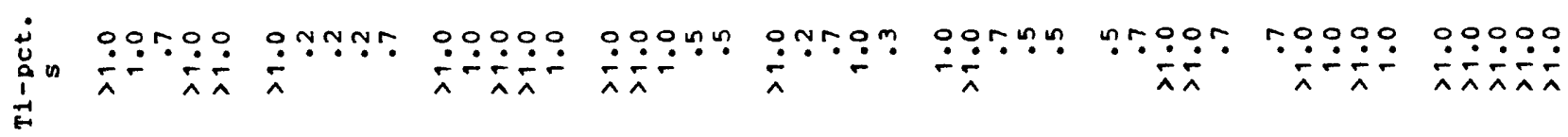
聯

응응옹요 응응응응

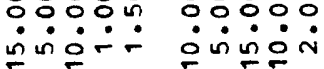

응융웅 붕ㅁㅇㅇㅜ

용ㅇㅇ음

응응응응

응응응 ư

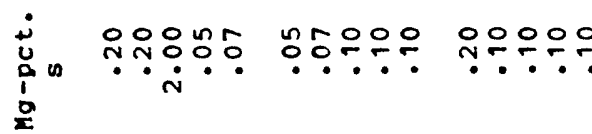

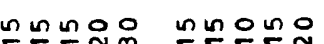

뜨ํํํำำำ

웅ㅇㅇ응ㅇ

응ㅇㅇㅇㅛ in $\mathrm{m}$ in $\mathrm{m}$ in in $m-$ ? iñinm

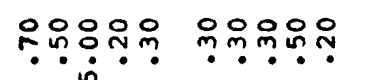
읍유옹으

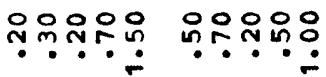
운유ํํํㅇ ํํㄴ요유 웅ㅇㅇㅇㅇㅇㅇ 운유유ํ운오 is

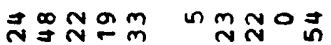

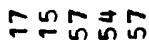
N ${ }_{n \rightarrow \mathbb{N}}^{\infty} \stackrel{\infty}{N}$ Nom

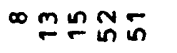
inํำ웅 mNํำก Oñี

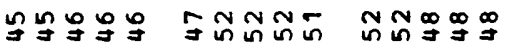
nnแnn nnnn nnn nn

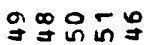

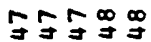

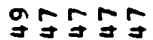

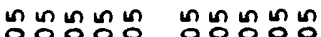
뜽ํㅗㅇ옹응 舟舟䒠寻寻 코워ํํํำ

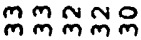
으으으으으 웅ㅇㅇㅇㅇㅇㅡ 우우유유은 으으유으으 으으유우 นกํํํํํํํㅇํㅇ

กำํำกำ ํํㅇํํํํำ

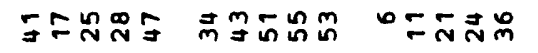

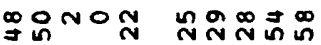
$\exists \infty 0 \mathrm{~mm}$ $\underset{m}{a}=m m_{m}^{\infty} \stackrel{\infty}{n}$ zัติ $\infty \pi \frac{2}{2}$

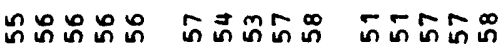

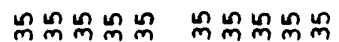

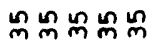

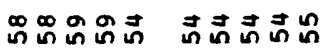

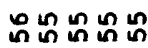

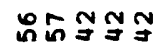

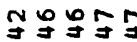

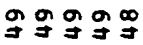

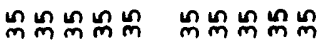

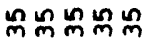

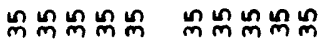

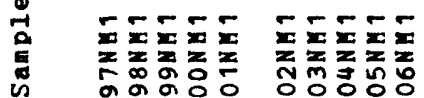

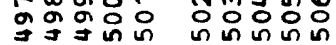

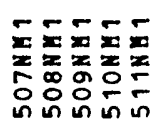

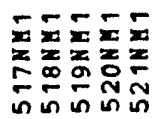

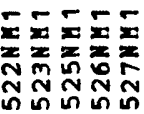

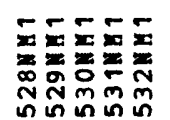

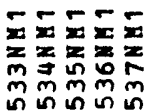

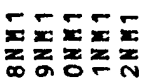

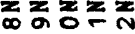
กิ 


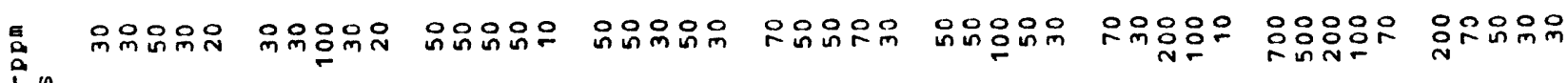
$i^{2}$

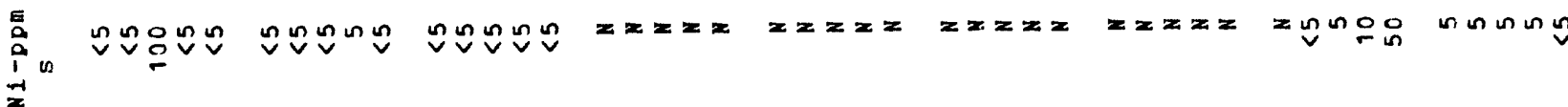

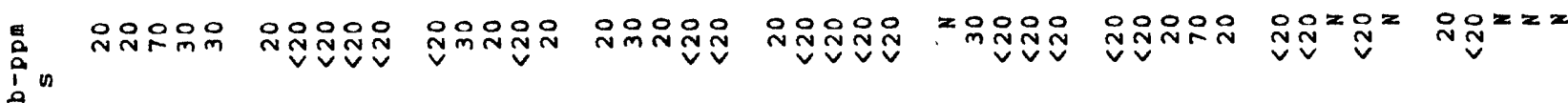

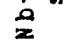

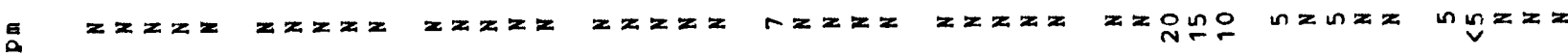
$i_{0}$ in

$\stackrel{1}{\infty}$

\section{응ㅇㅇㅇㅇ 응응응}

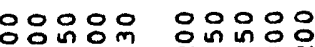

옹옹으

은영영응응 응영음

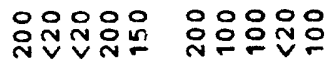
$\therefore$

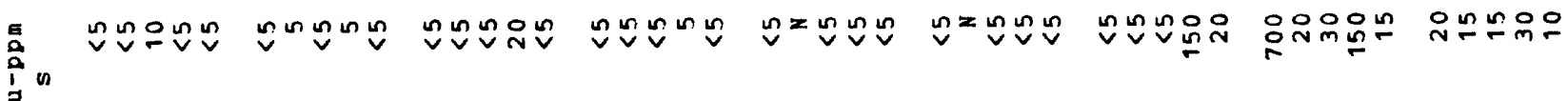

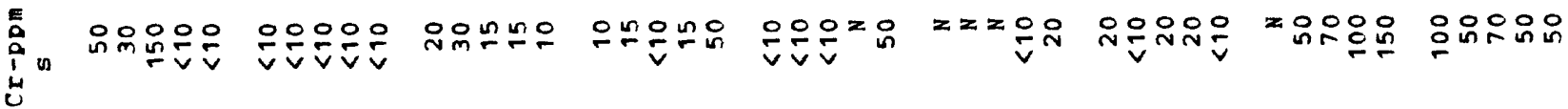

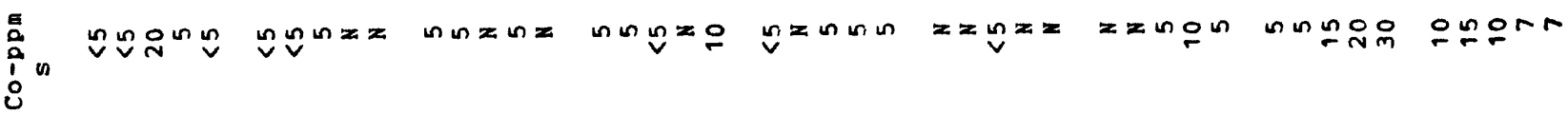

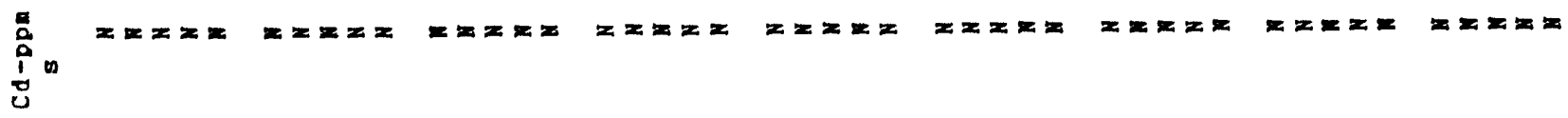

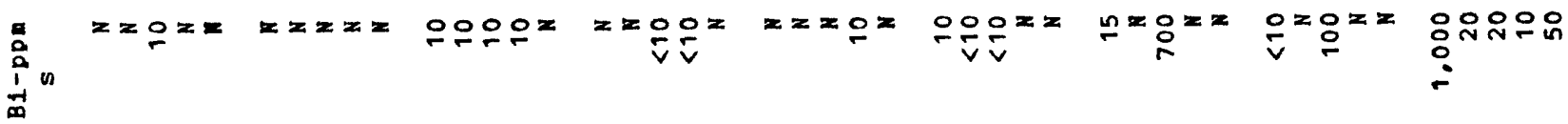
in

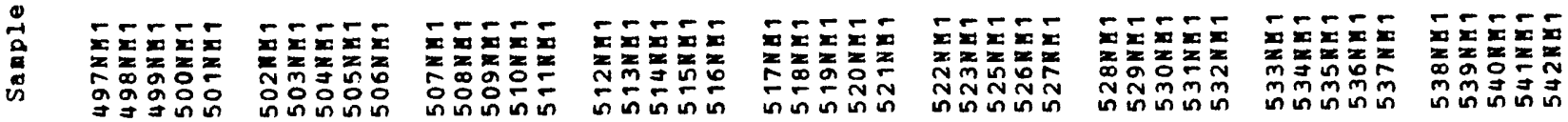



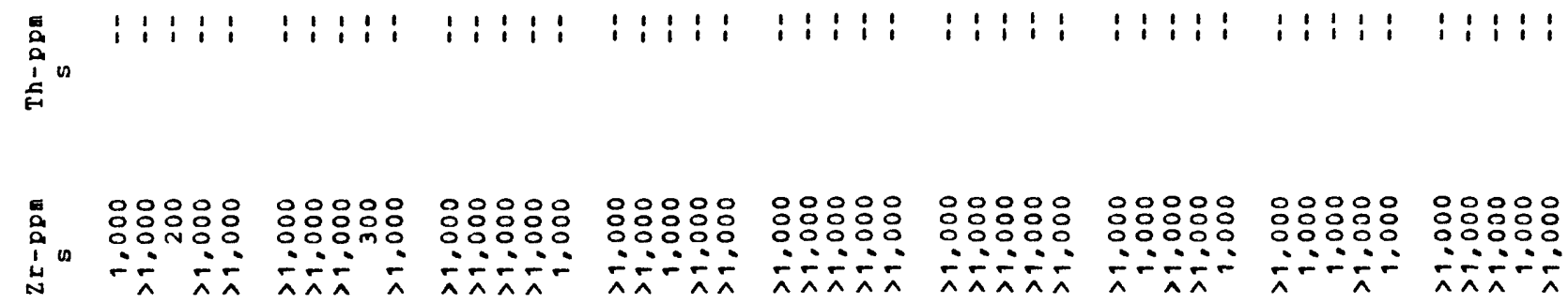

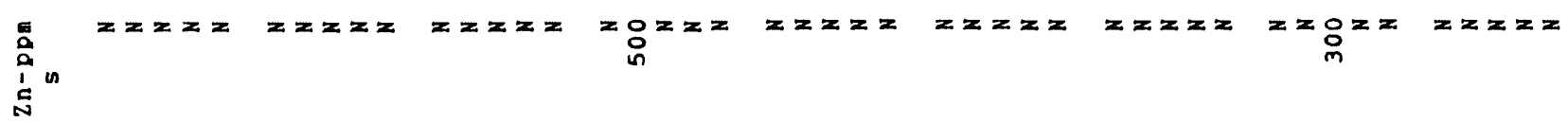

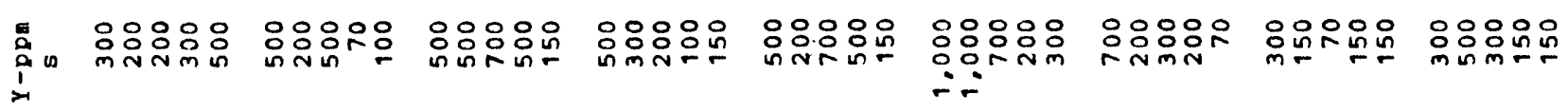

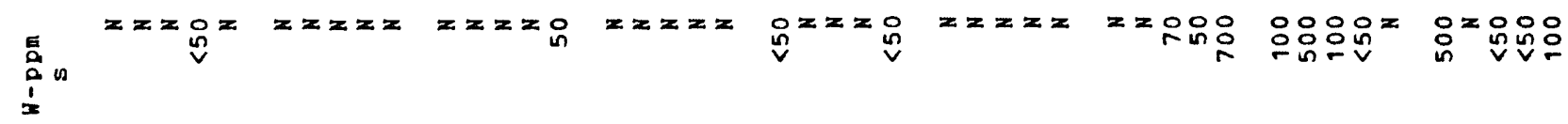

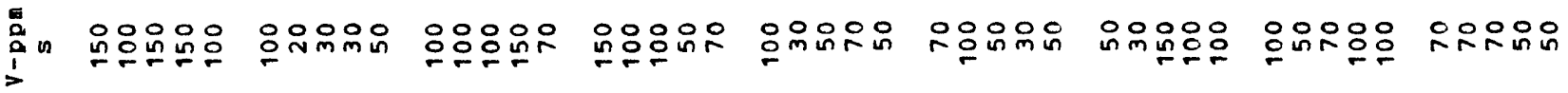

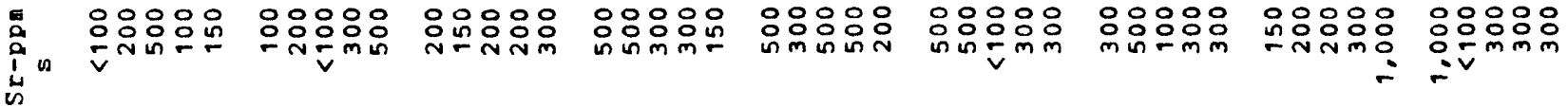

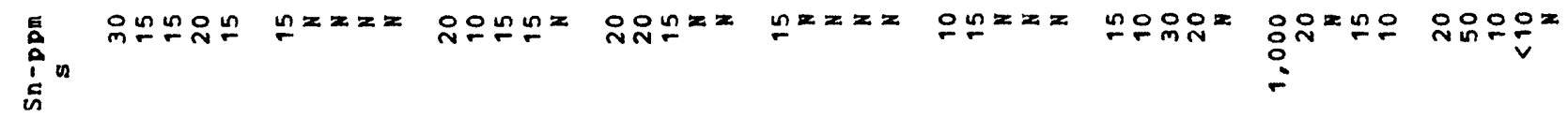

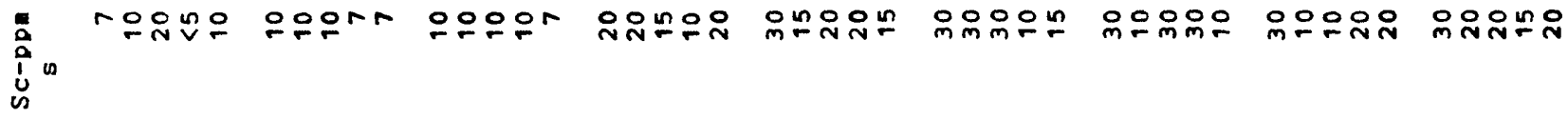

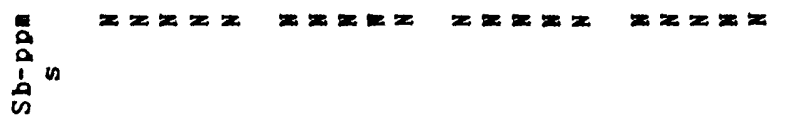




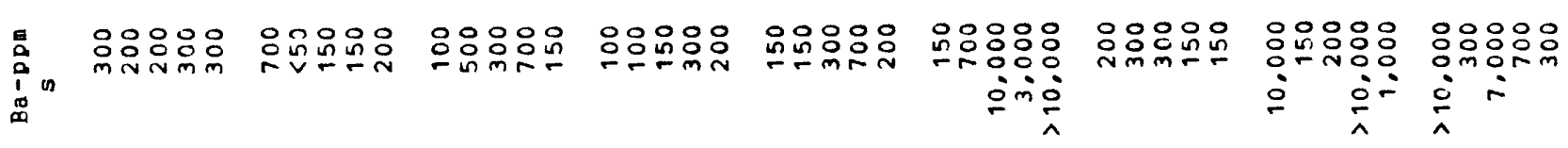

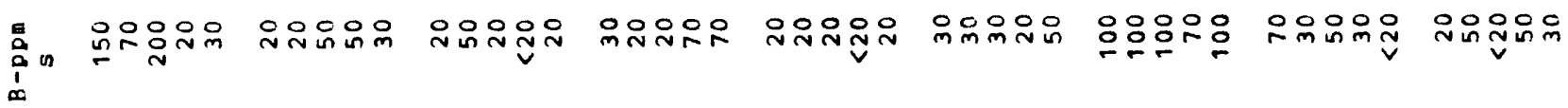

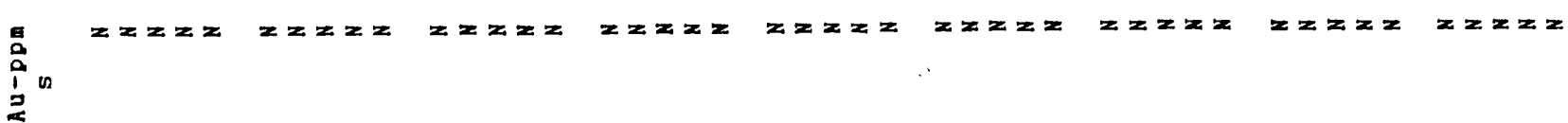

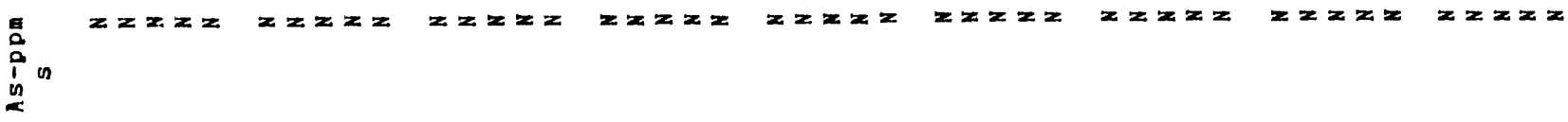

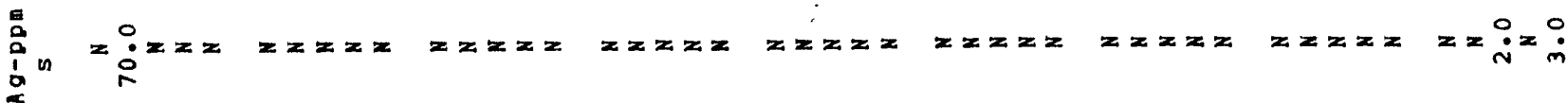

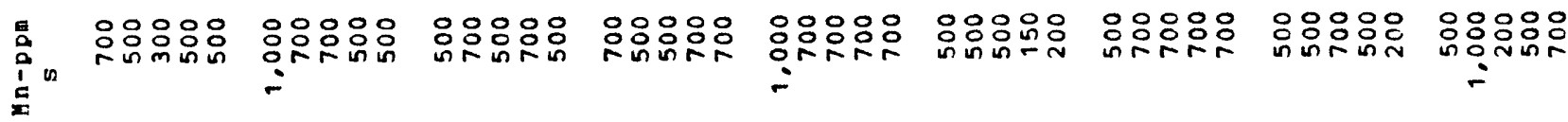

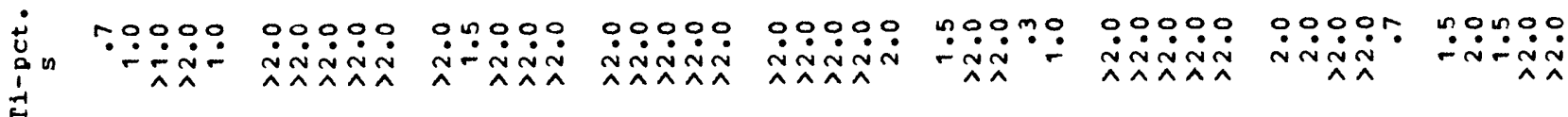

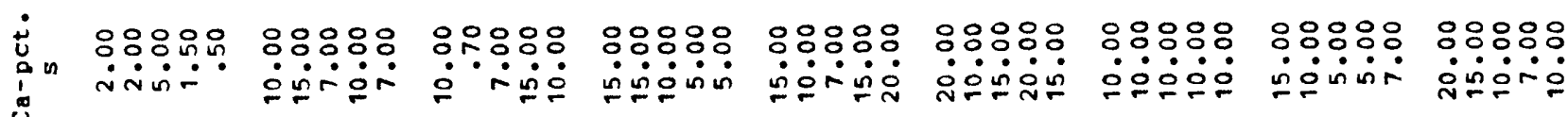

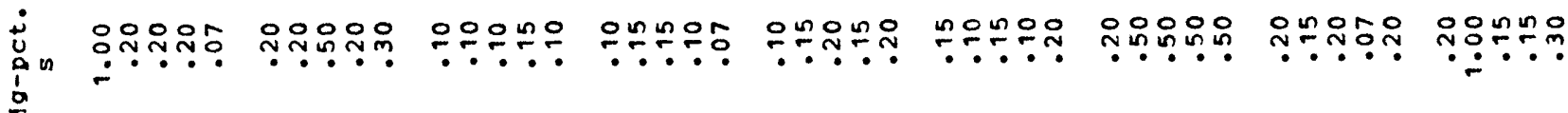

a

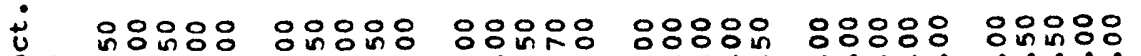

蕰

$\dot{n} \dot{m} \dot{n} \dot{n} \ddot{\circ} \dot{n}$

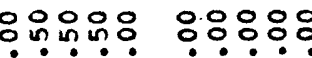

唯

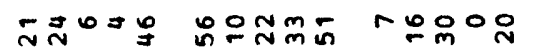

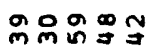

0 오용

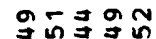

ํํำ코요

ํํำธธ่์

$\stackrel{m}{\exists} \underset{\exists}{m} \stackrel{\infty}{\exists}$

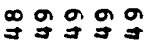

路的约

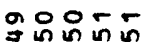

กิกำกำ

을영의

눜웛워

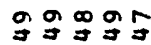

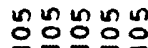

ํํㅇํํㅇํㅇ응

ํํㅇํํㅇํㅇํㅇㅇㅇำ

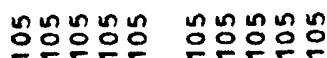

กn⿺n一

nn $n$ in

nn

जing-n

m

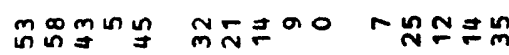

름ํํํำ

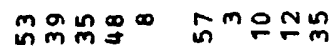

กำำ

우융

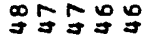

号昌牙矛可

可可

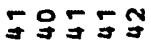

戸55う5

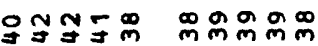

웅웅여

눙융응응응

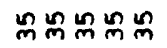

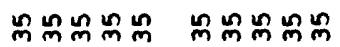

凩雪出品品

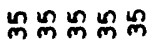

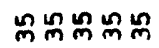

nnmmnn

禹㧱的品

ํํำำำ

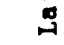

告

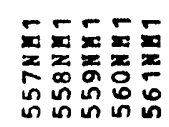

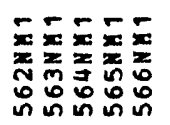

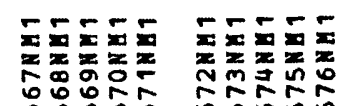

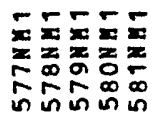

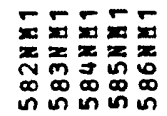

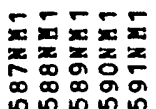

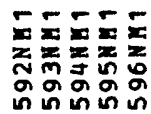




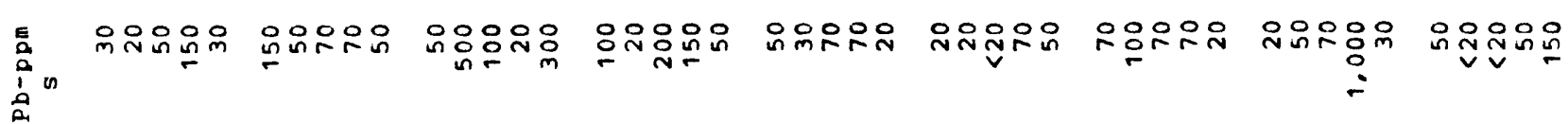

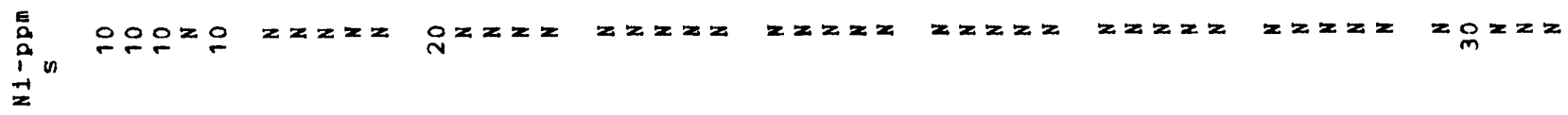

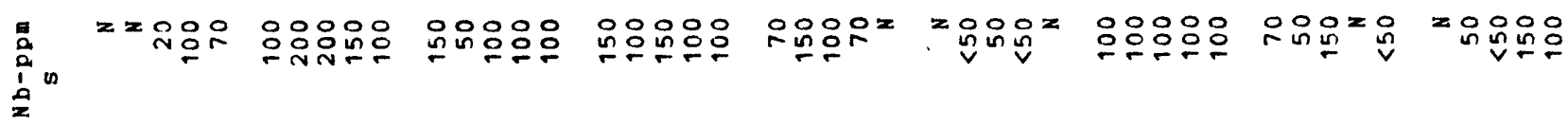

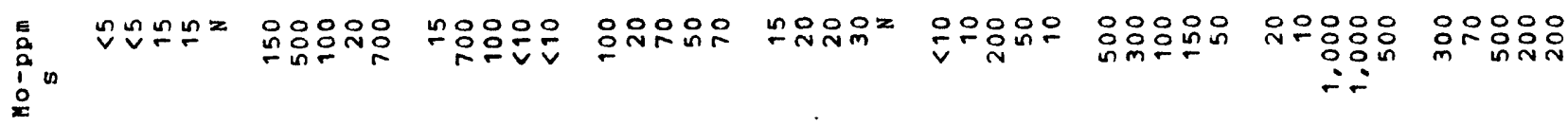

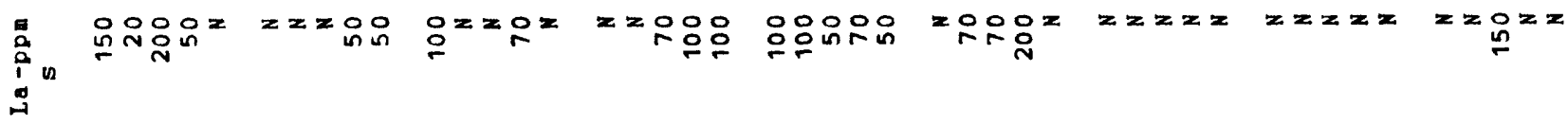

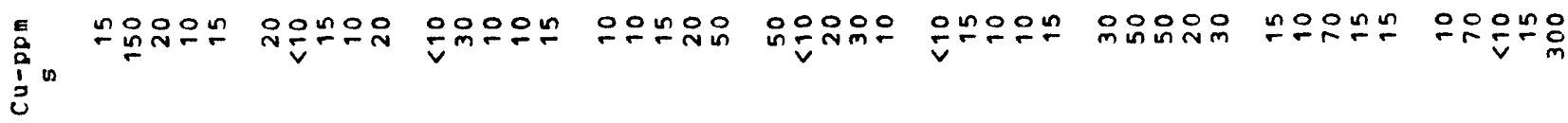

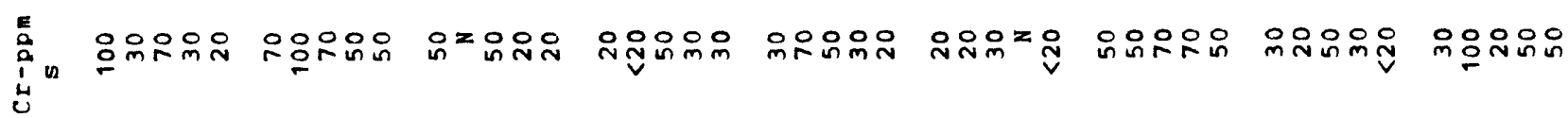

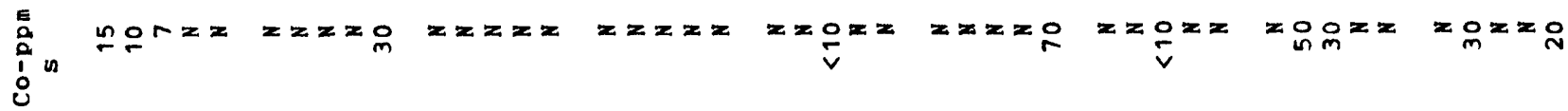

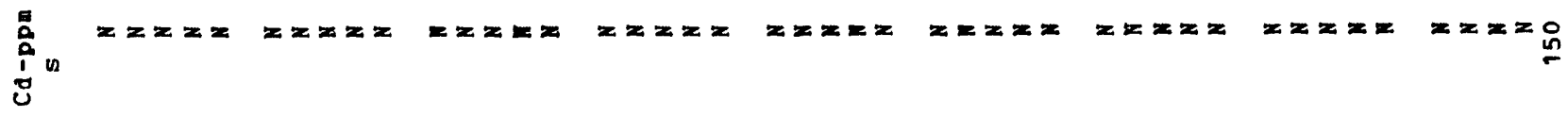

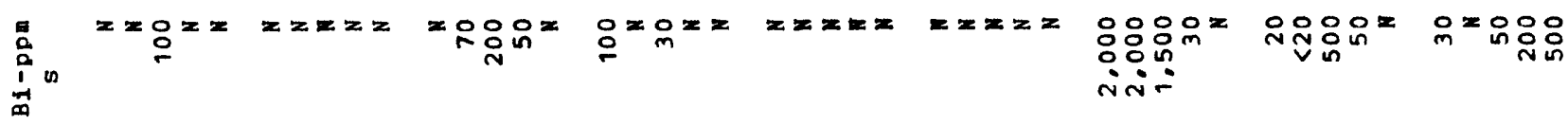
茲

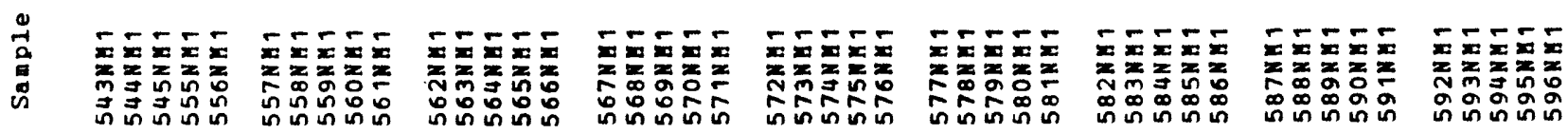




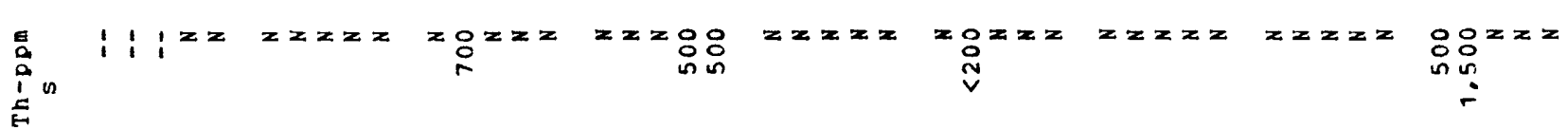

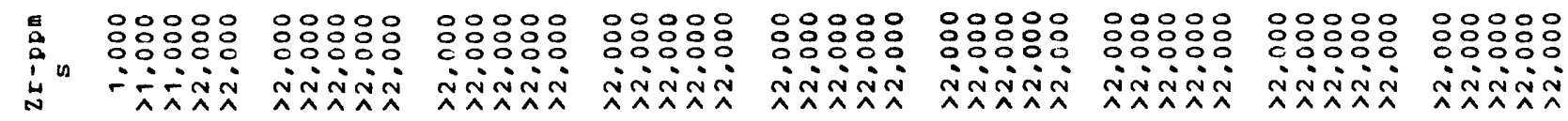

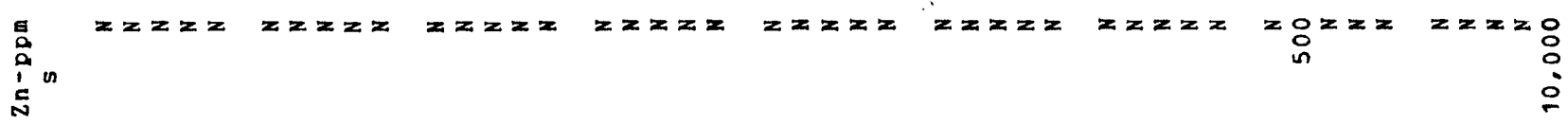

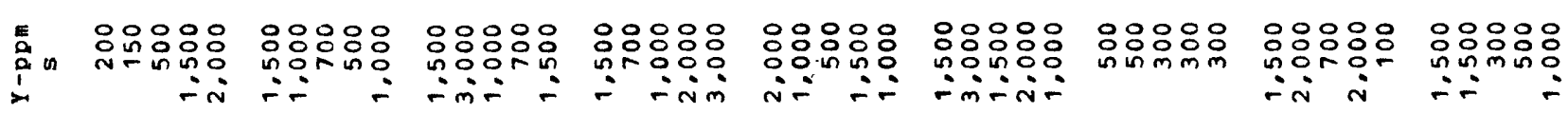

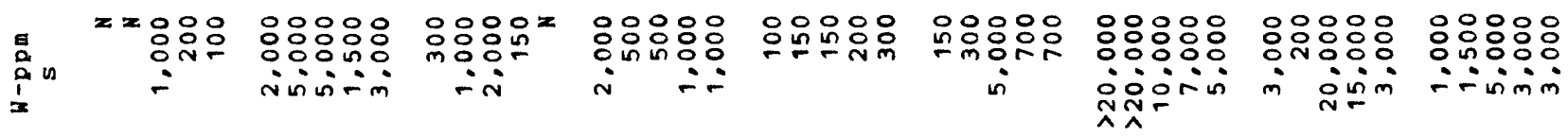

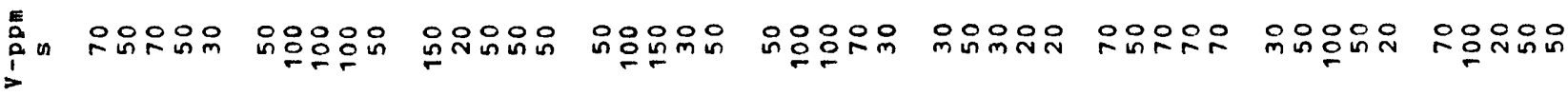

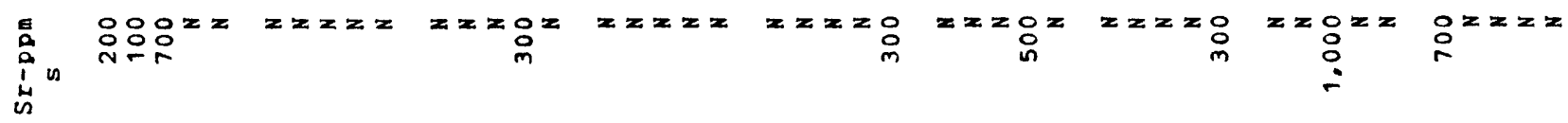

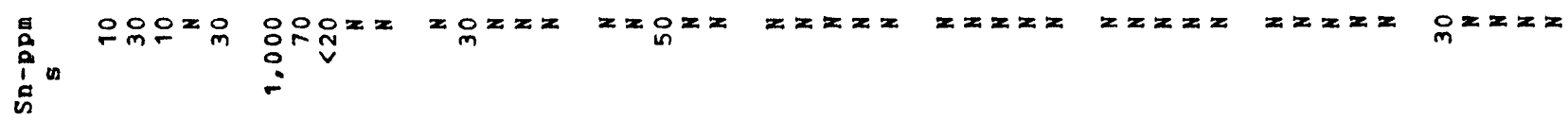

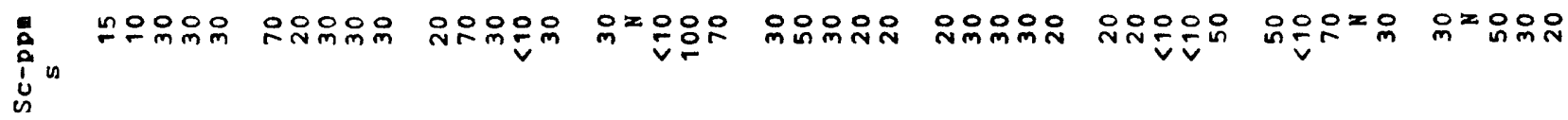

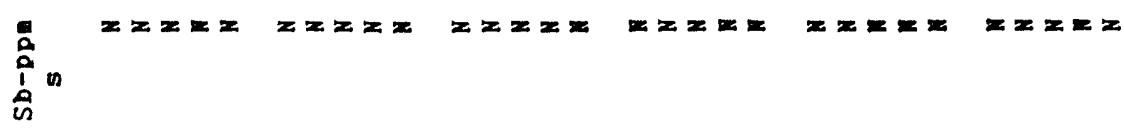

$=x z=x$ 


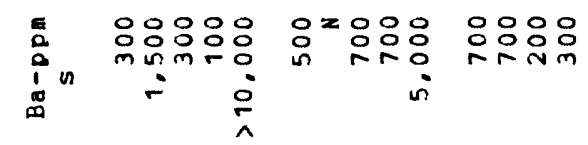

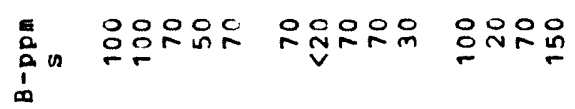

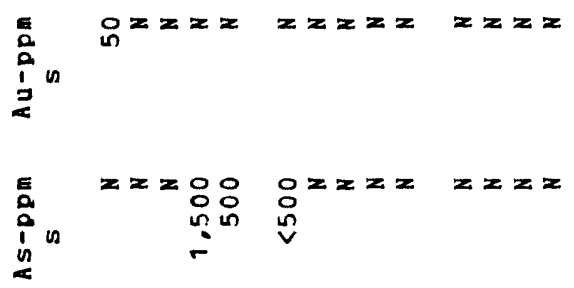

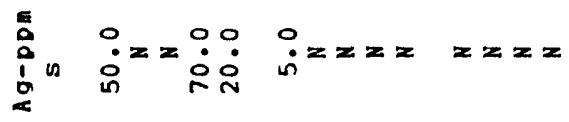

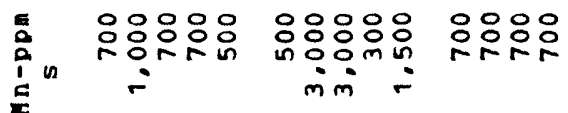

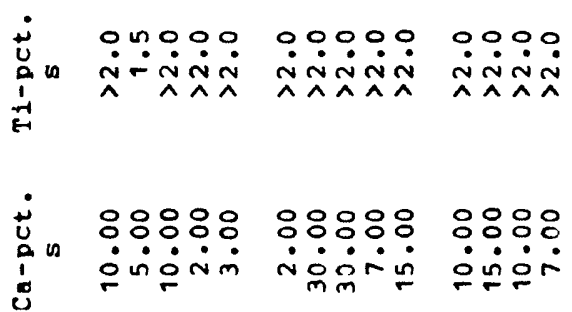

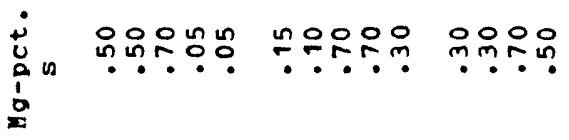

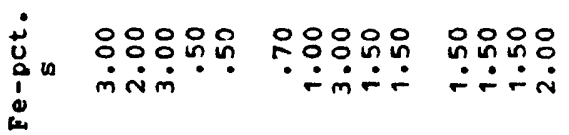

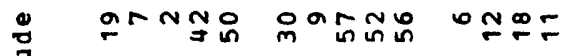

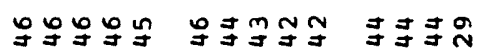

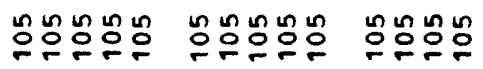

$\stackrel{\dot{m}}{\stackrel{\omega}{0}}$

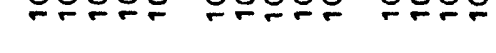

: $\quad$ ㄲNNํำ

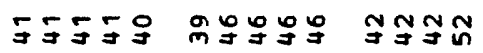

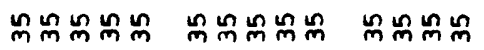

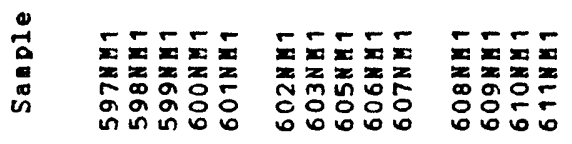




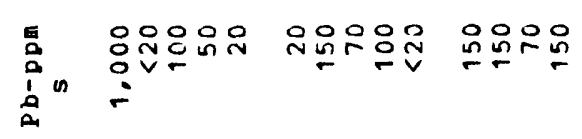

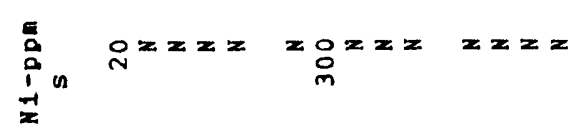

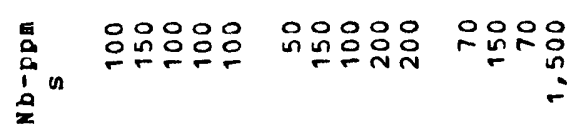

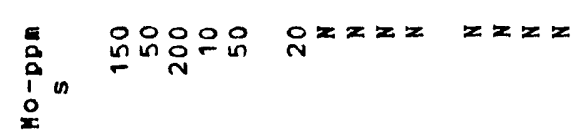

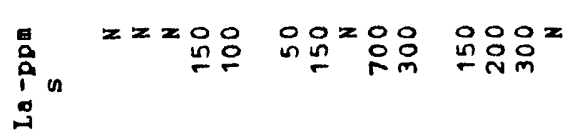

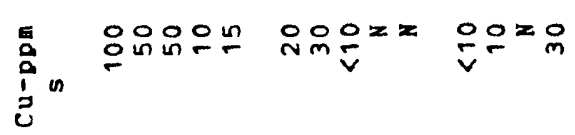

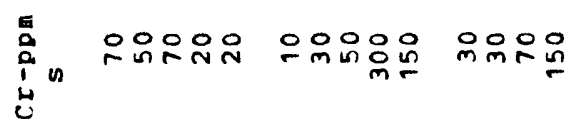

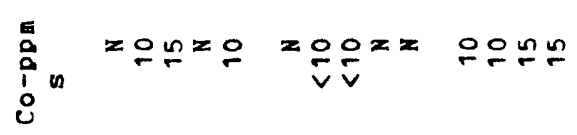

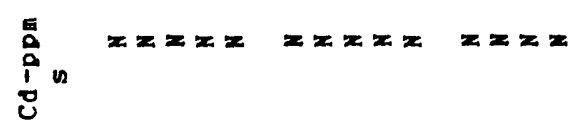

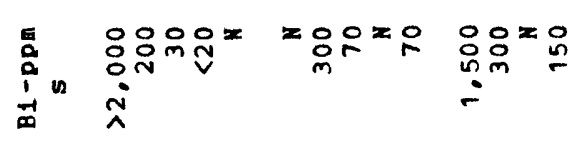

总

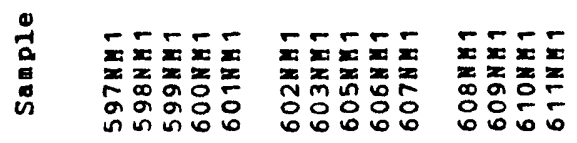




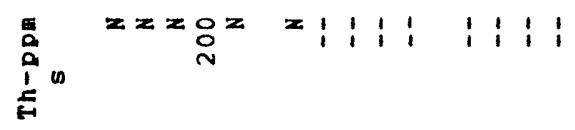

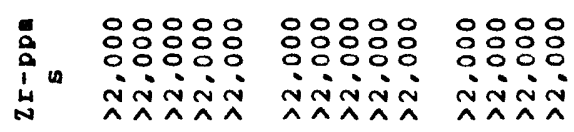

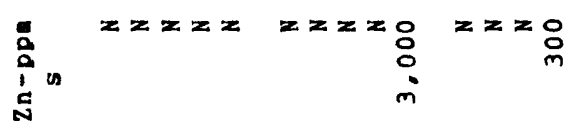

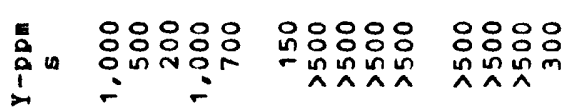

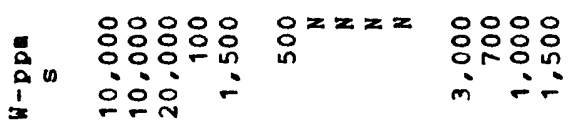

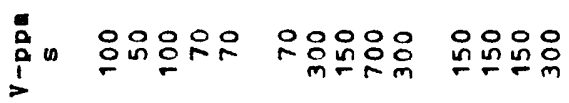

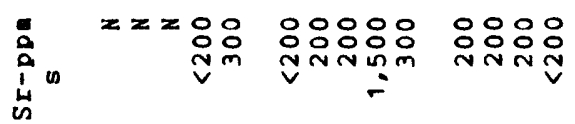

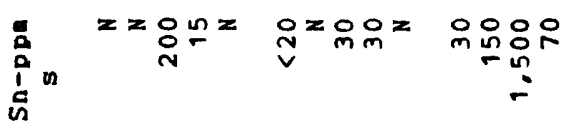
。

in

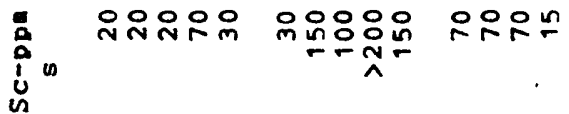

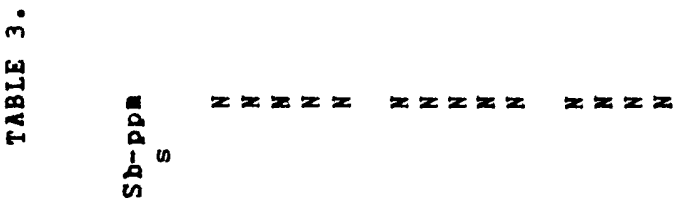

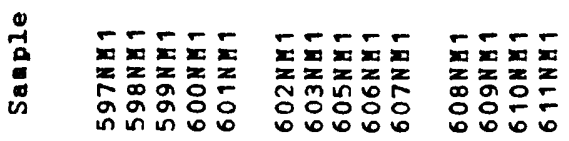




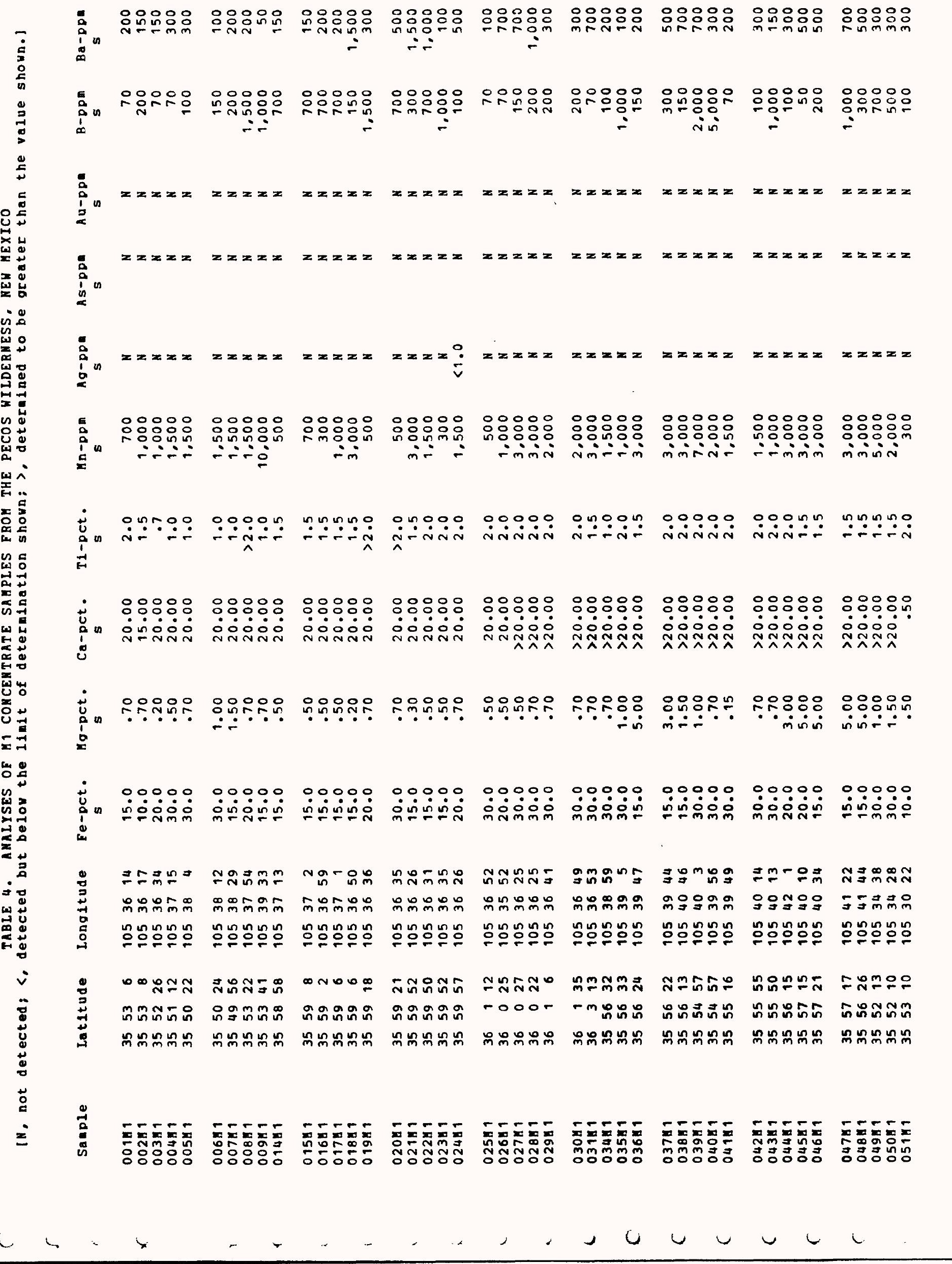




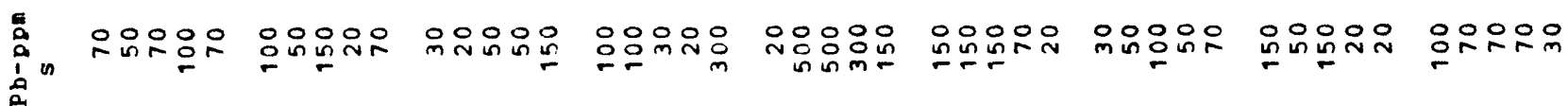

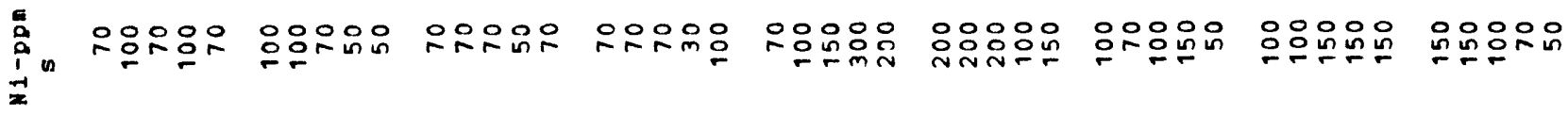

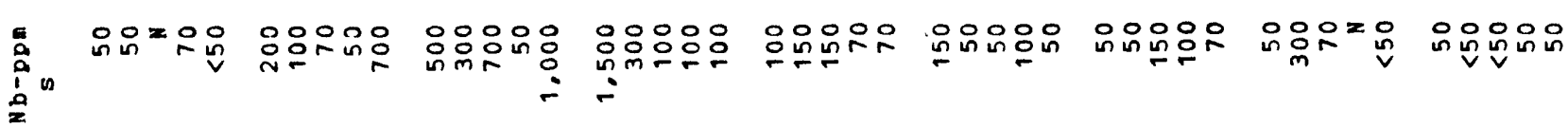

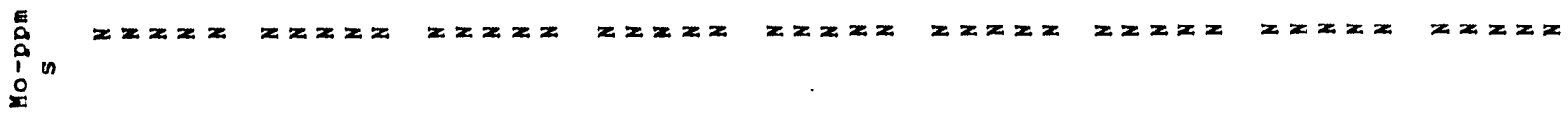

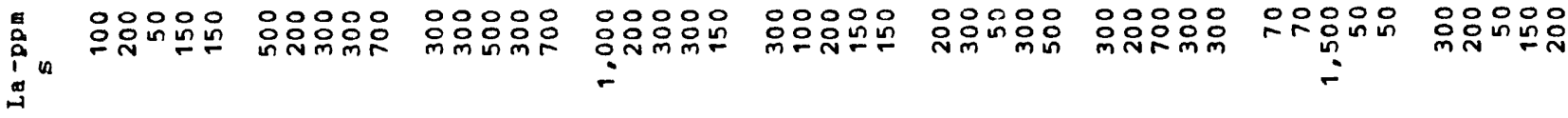

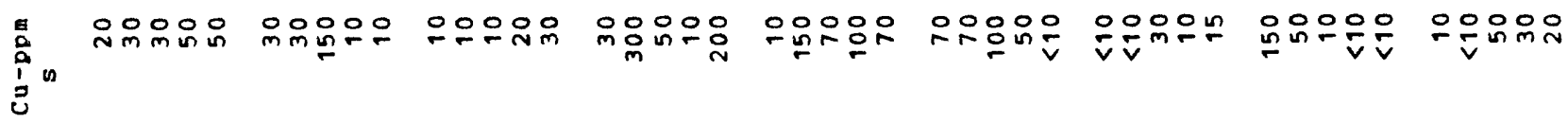

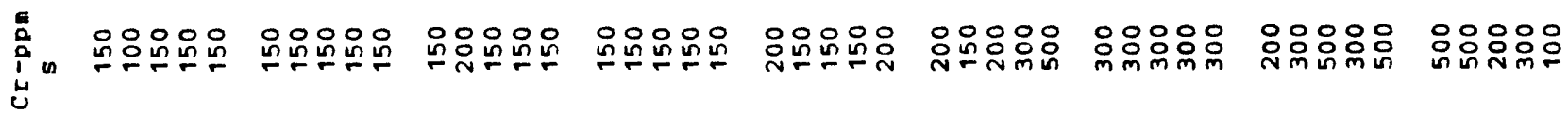

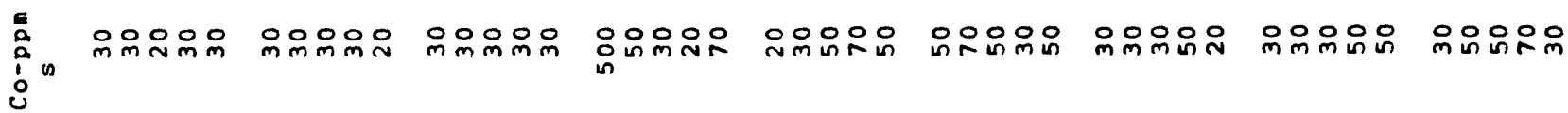

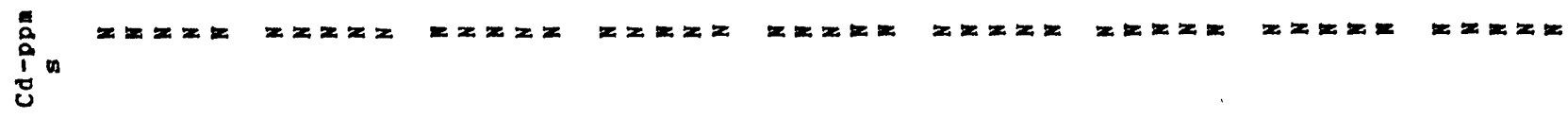

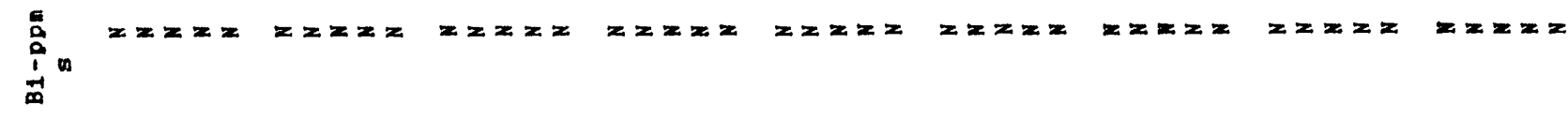
要

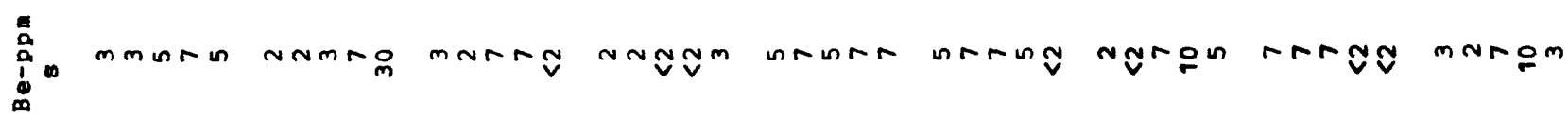

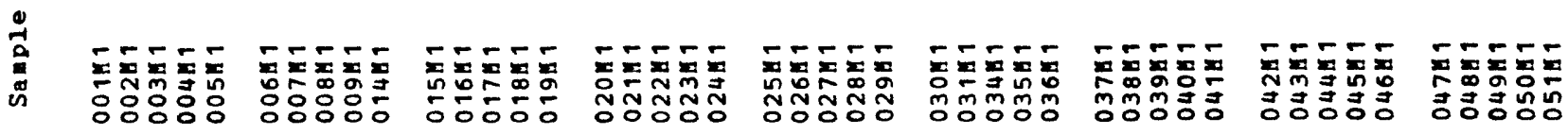




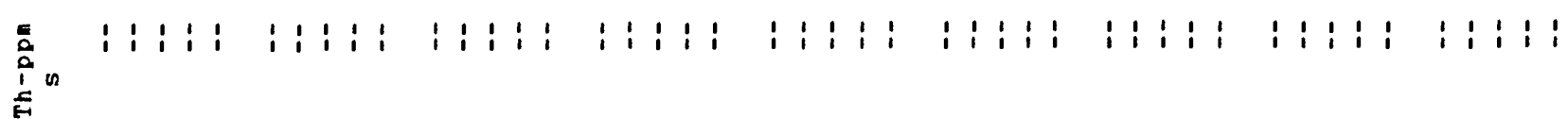

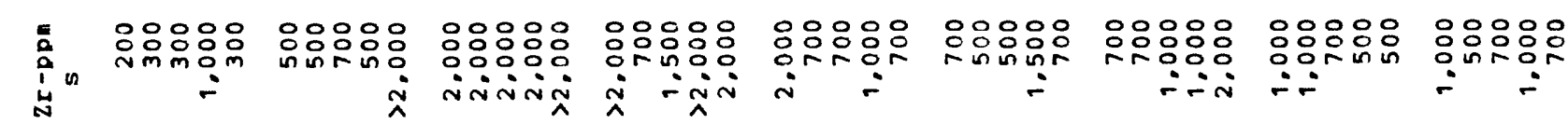

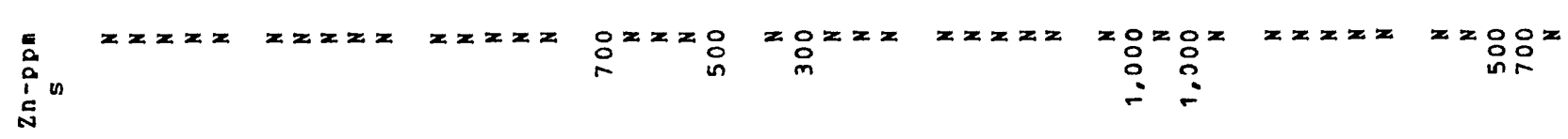

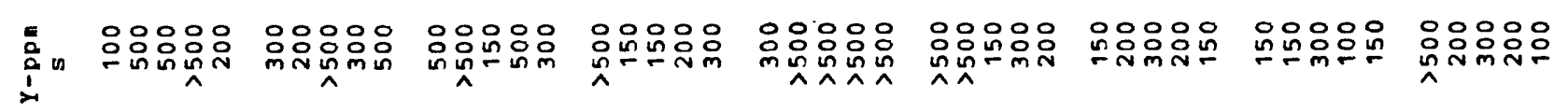

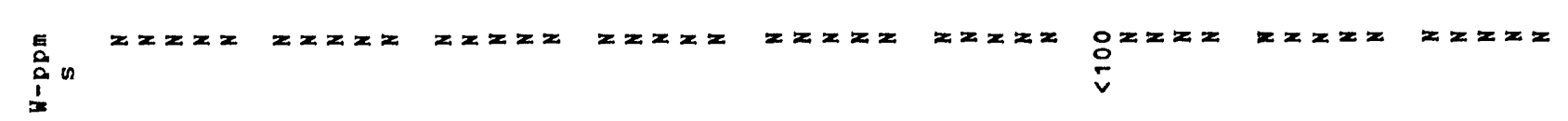

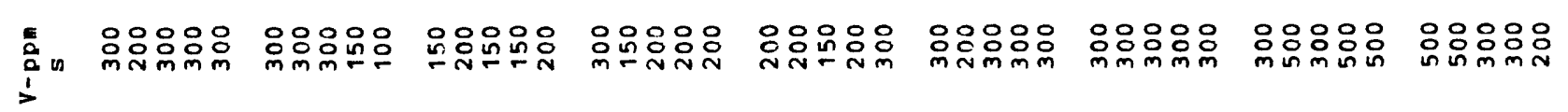

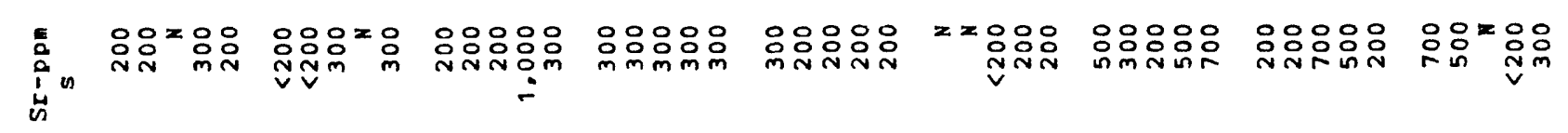

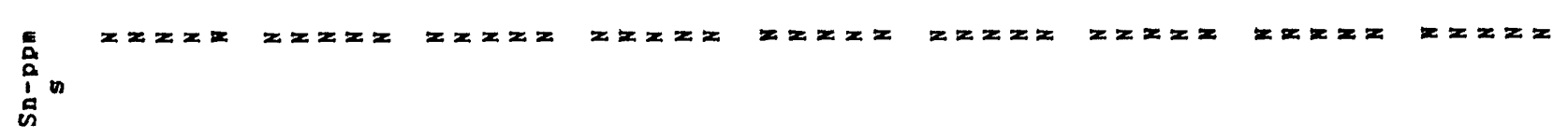

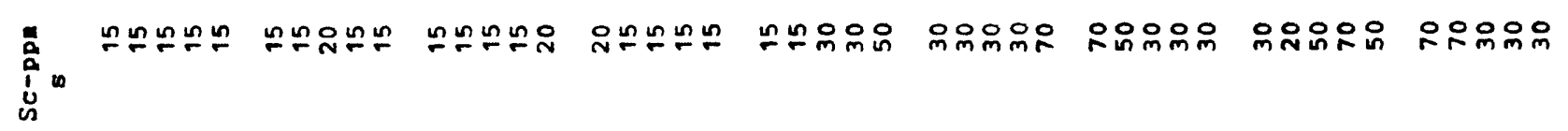

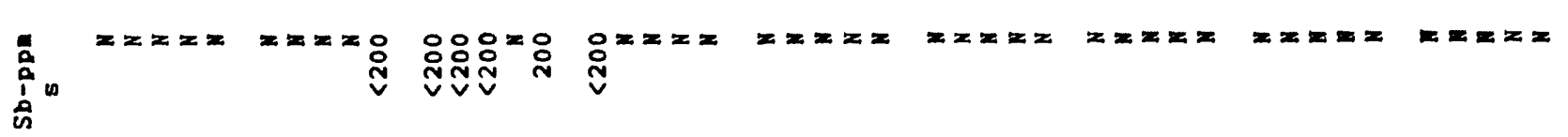

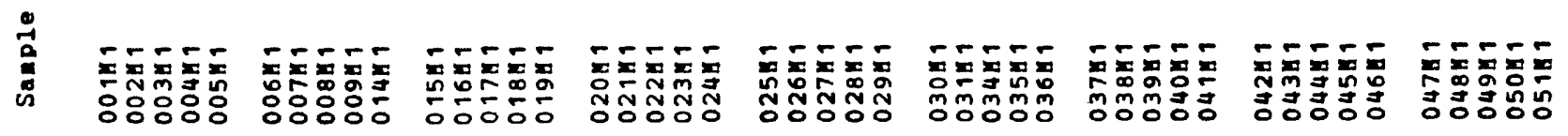




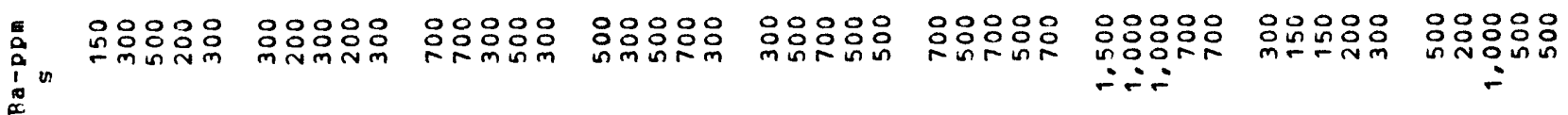

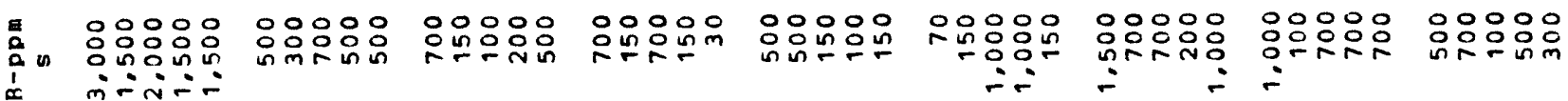

$\frac{1}{3}$

$z z z z z z z z=$

$x=2 x$

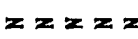

$x z x x$

$z x \geq z$

$x x=2$

$z x z=$

$x z x z$

$z z z=$

$z=2$

$z=z=$

$z=2 x z$

$z x z=$

$z z z$

$z=x=$

$x z z x$

$z z x=2$ in

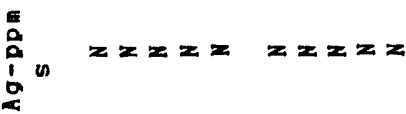

$z x z=x \quad z x z=x$

$z x z z=$

$z=x z$

$z=x=2$

$x z x z$

$z z z z$

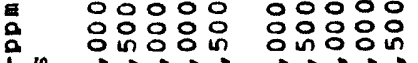

in $\because \because \frac{m}{4} \because \dot{m}$

웅응ㅇㅇㅇ

뭉응요요

i的 :-

영웅응음

in 0 in

웅웅응

000 nn

inin

웅웅응

oo

inivin

웅ㅇㅇ

응응응

imin

응영웅

응응ํㅇㅇㅛ

용ㅇㅇㅇㅇㅠ

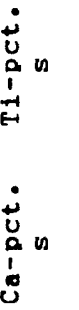

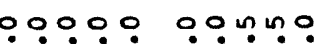

0.7.0. 0.90:. 0...?

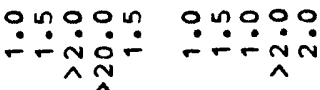

ㅇํㅇำ

$\dot{4} \dot{4} \dot{4}$

0.0000

Nañ

in

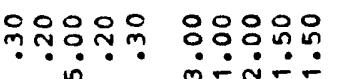

영영우은

응으용요

응ㅇㅇㅇㅇㅇㅇㅇㅇ

오융웅ㅇㅇㅇ

응운온ํำ은

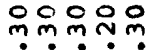

은옹ㅇㅇㅇㅇㅇ

Nmm

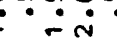

-r n

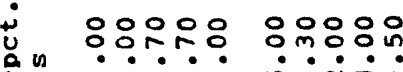

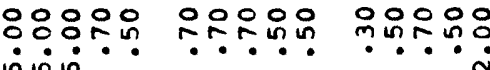

…

우웅웅ㅇㅇ응

영응이우

응옹오운운

$\therefore \because$ in

min.

$\therefore \because$

융ㅇㅇㅇㅇㅇㅇㅇㅇ :

莏

00000

잉요요

00000 i̊mio

$: 00: 0$ í $\sin 0$

00000 :

กN

응욜

oñon

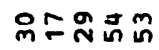

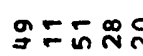

\section{용}

$=09$

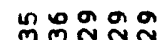

$\stackrel{\infty}{\sim}$

$\infty$ a $\infty \infty$

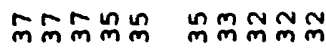

\section{以U}

ํํㅇํํㅇํํำํํㅇํำ

Nmmmm $m$

ํㅗㅇ응ㅇํㅇ

ํํㅇํํㅇํㅇ응

กNNM

퐁ํำ

on $=0$

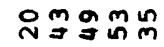
으웅으응ㅇㅇㅇㅇㅇ은

으으응ㅇㅇ 우우으응

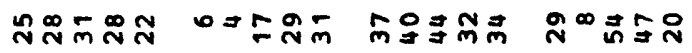

$\stackrel{\infty}{n} \underset{\sim}{\sim} \neq 0 \stackrel{m}{m}$

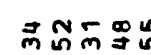

ํํㅇํㅇํํㅇํㅇ

ㄴํㅇํํㅇํㅇㅇํㅇํㅇ

영여욮

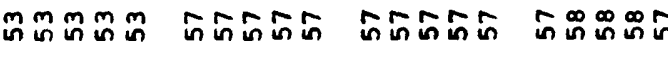

ํํํํํํํํํㄹ

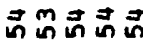

느요의

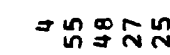

ํํㅇ으응ํํ은

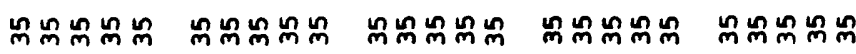

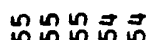

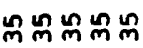

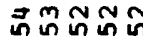

กูm

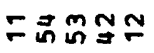

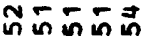

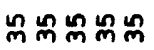


军

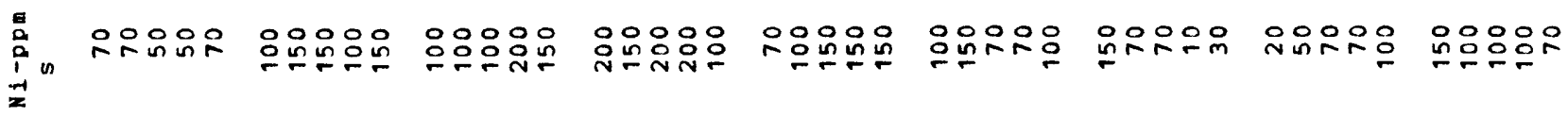

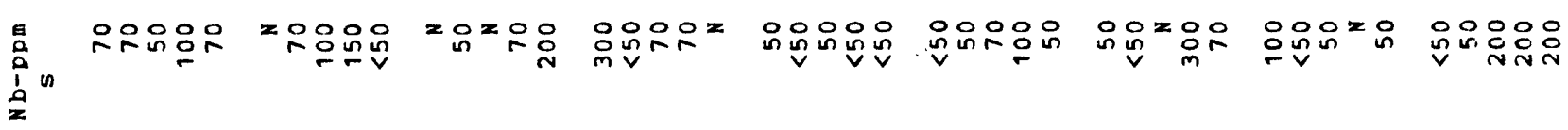

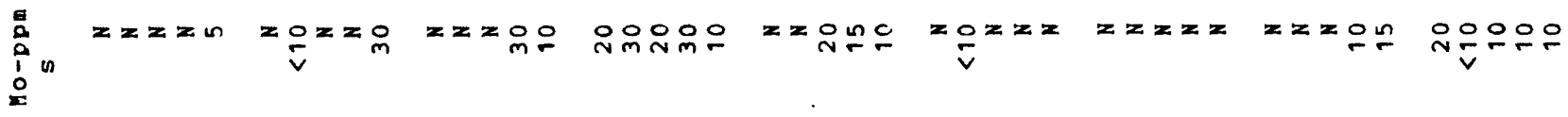

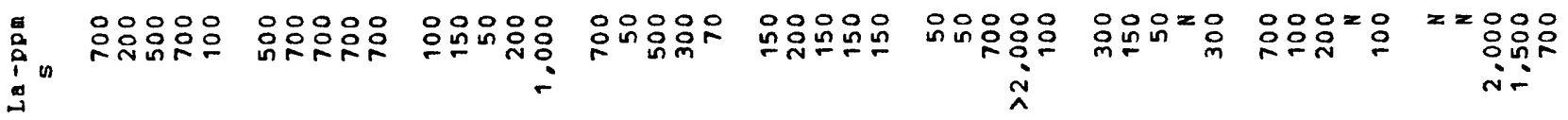

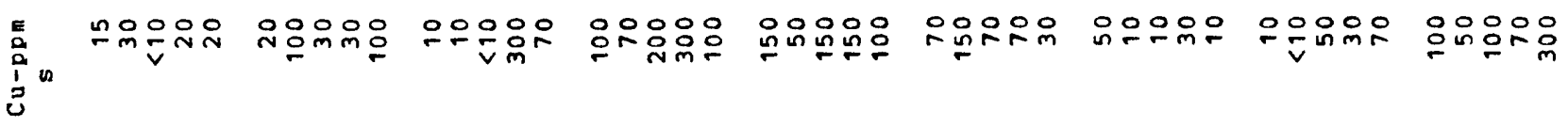

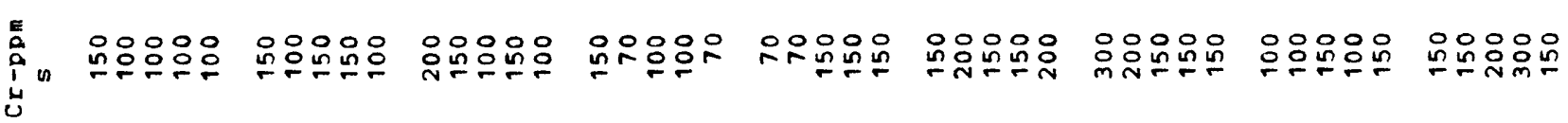

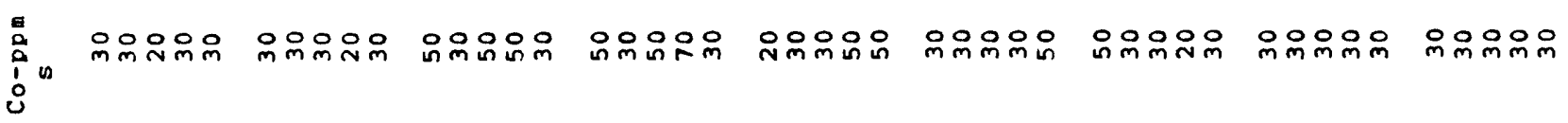

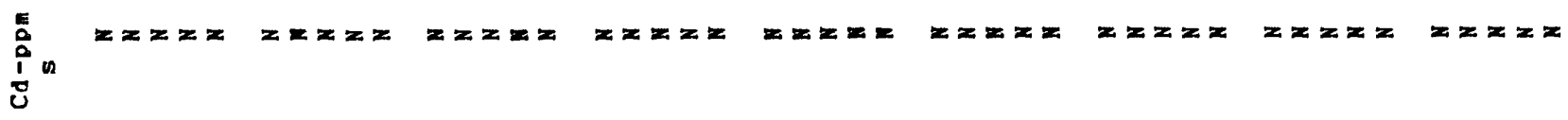

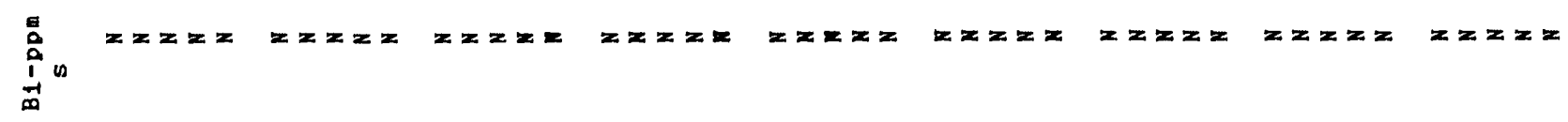
:

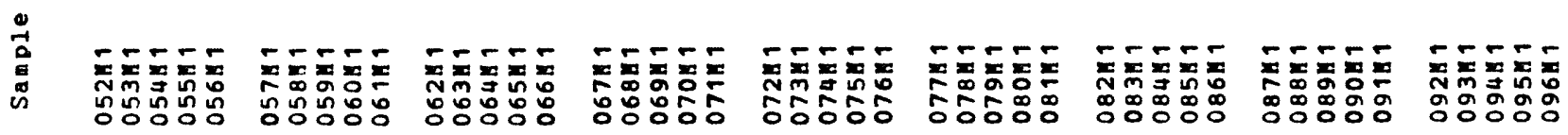




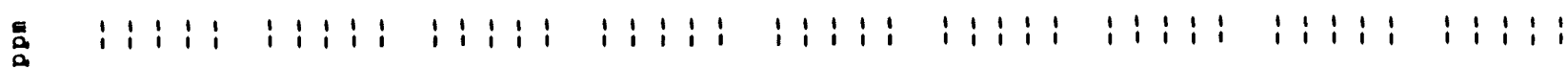
$\sum^{2}$

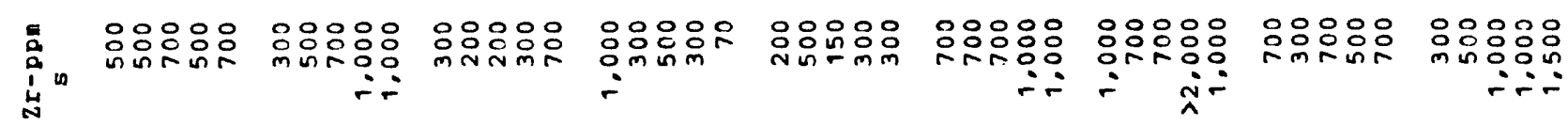

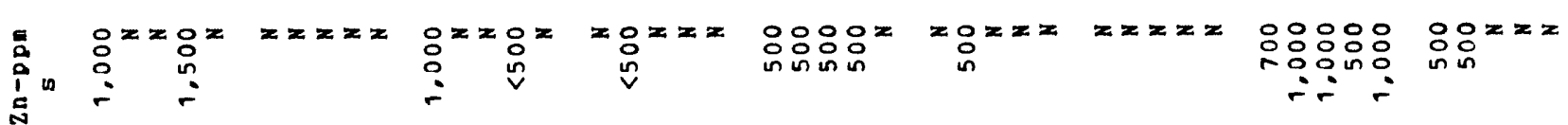

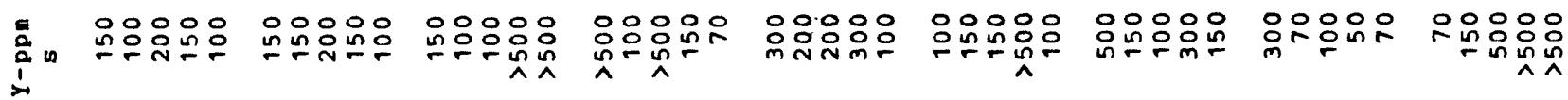

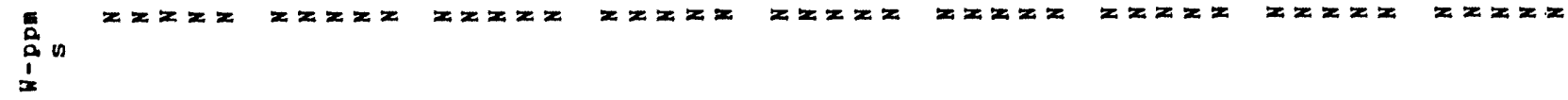

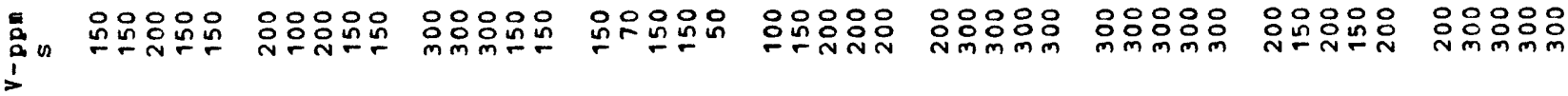

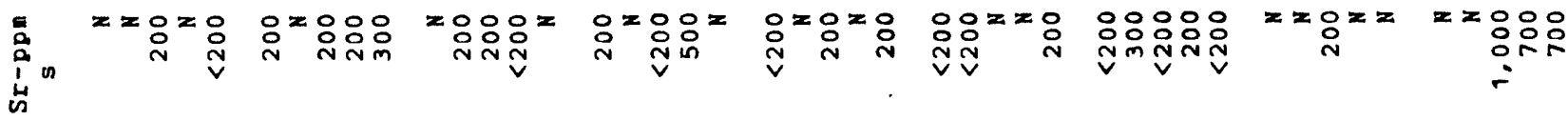

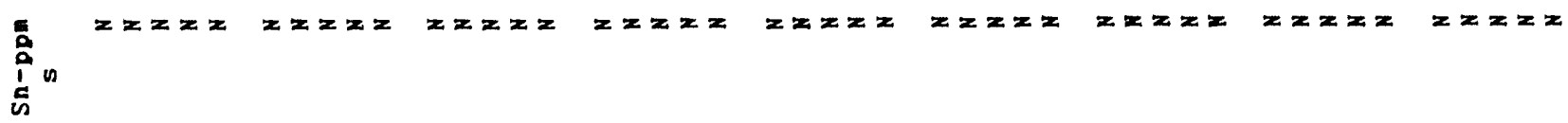

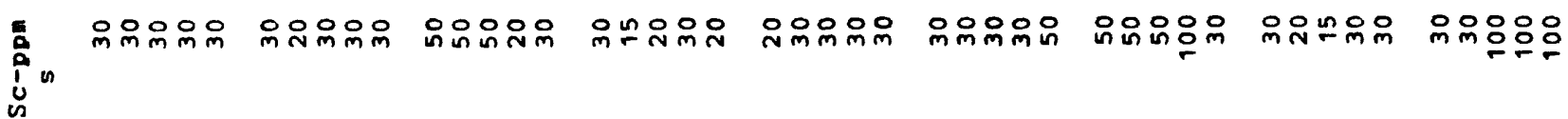

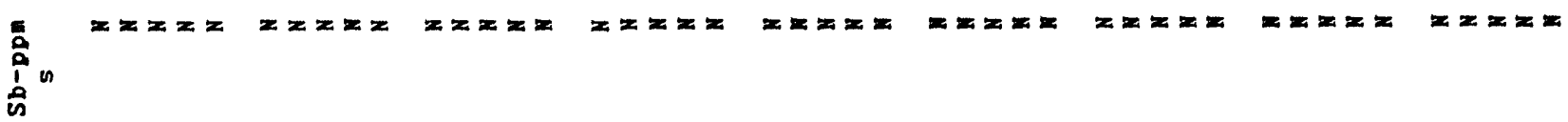

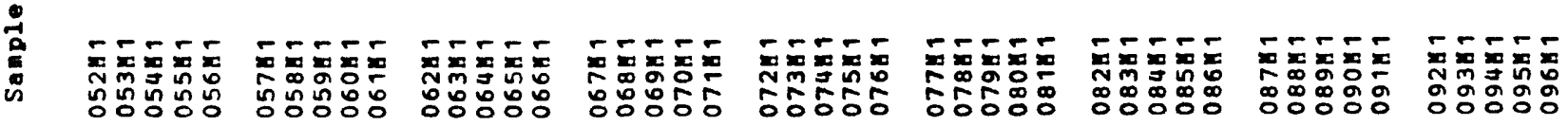




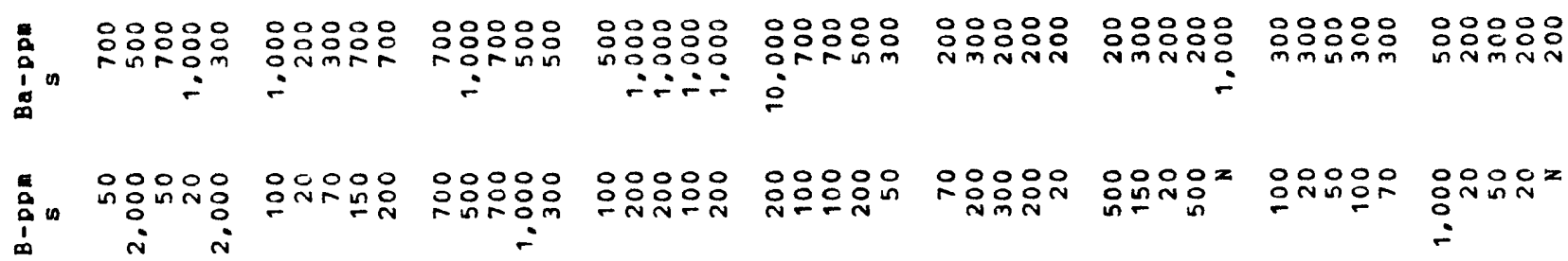

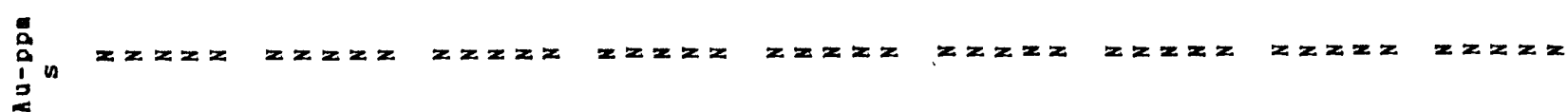

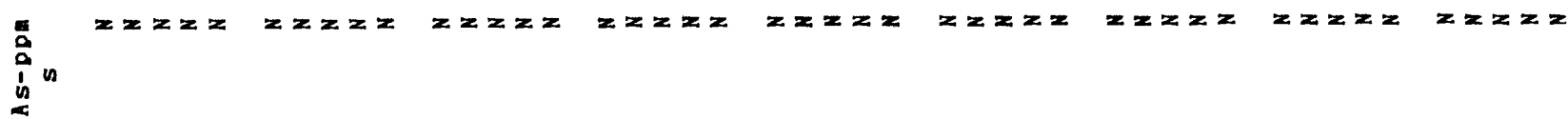

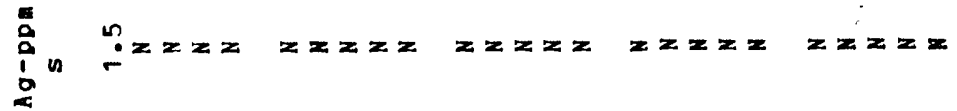

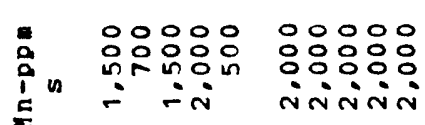
응ㅇㅇㅇㅇㅇㅇㅇㅇ웅 응ㅇㅇㅇㅇㅇㅇㅇ 응영용

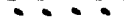
iñतi

응ㅇㅇㅇㅇㅇㅇ $\because$ in: Nm-m i ooono ooomm

Un $\rightarrow$

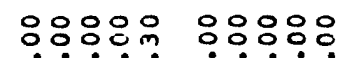

藏的 is

$\dot{u}$
$\vdots$
$\vdots$
0

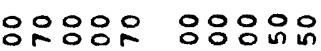

응ㅇㅇㅇ요유

응융ㅇㅇㅇ웅

$\because \because \div \dot{0}$

운우운유온

은웅요운?

은오옵용

$\ddot{\sim} \because \because \because$

ํำำำ

$0.0 \% \div$

응응응응으 $\dot{\sim} \dot{0} \dot{\circ}$

응응용 जिंنिंखि

응응요응응 mंோே்

옹응웅응 $\dot{m} \dot{m} \dot{m}$ in

응응융 ํำำำ? (n)

0000000000

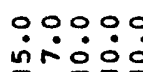

$0: 000$

00000

웅유요

$0: 000$

in $\operatorname{si} 0$

i

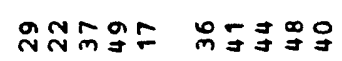

N $\mathbb{J} \mathbb{Y}$

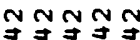

을 ज्ञ

$\operatorname{mgn} \underset{y}{*}$

NFom

กิํํำ

ํํㅇํํㅇํㅇํำ

ํํㅇํํㅇํㅇ응

ํㅗㅇํํㅇํㅇํํㅇํㅇ

ํํㅇํํํํㅇํㅇ

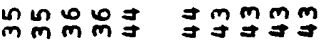

นn แnn

แกำแำ

느이우으 으우우우은

ํํำํำ ㅊํำํํำ

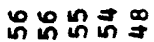

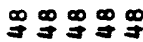

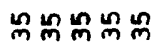

웅ㅇㅇㅇㅇㅇ

ini:-

영우웅 웅웅응 نंi்.

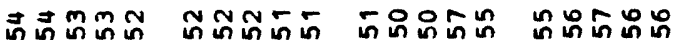

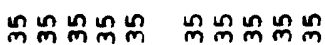

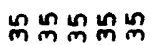

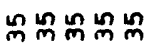

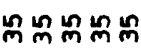

$\min \Rightarrow 0 \%$

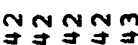

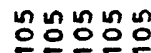

nN5

丳罗号

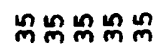

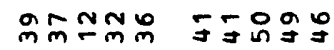

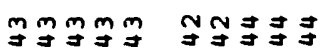

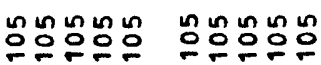

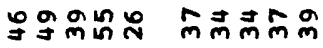

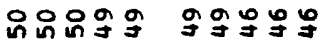

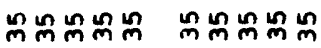




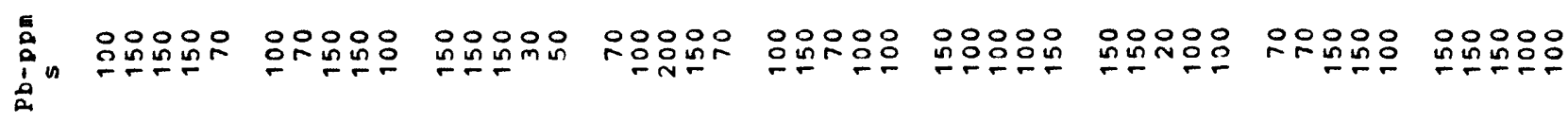

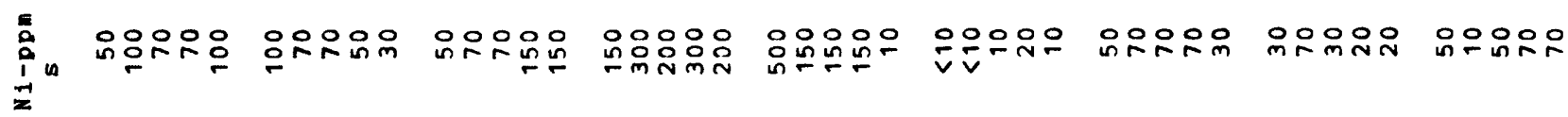

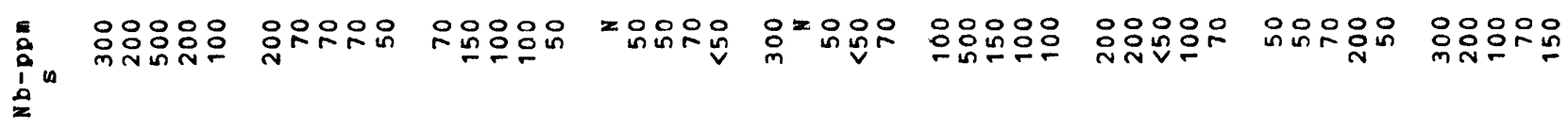

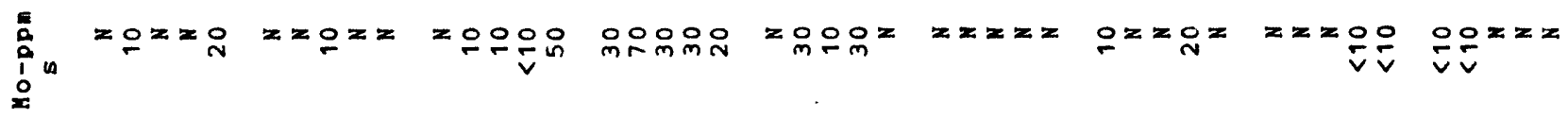

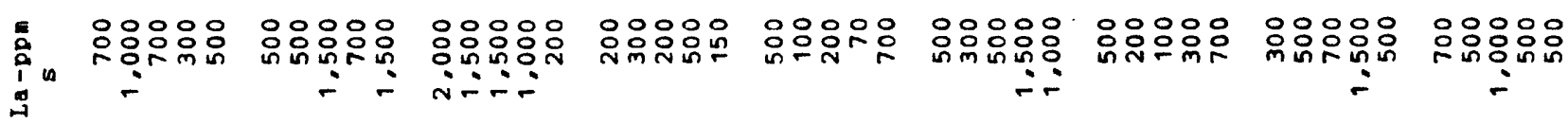

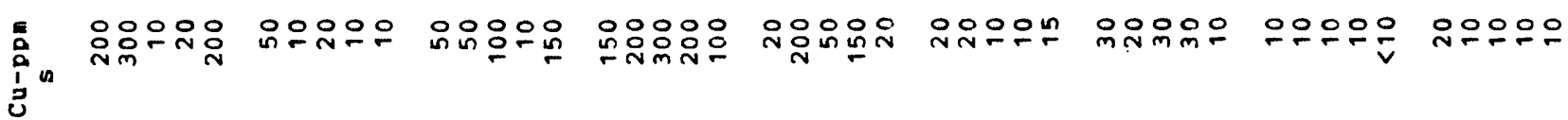

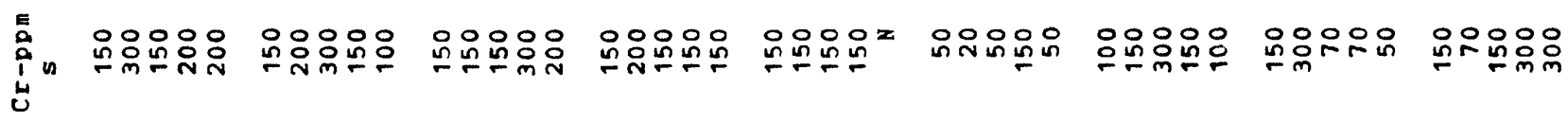

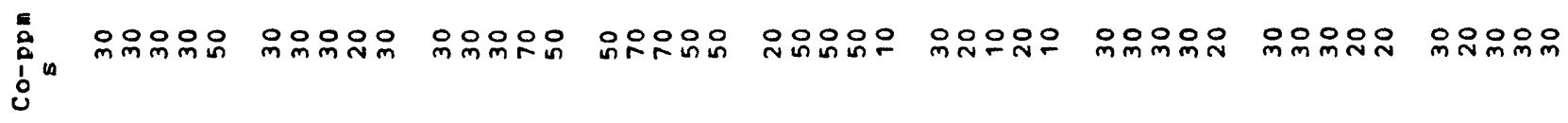

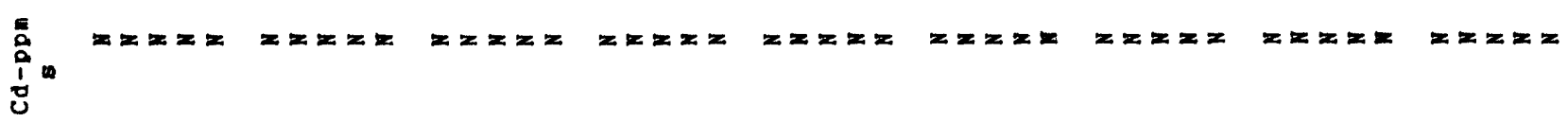

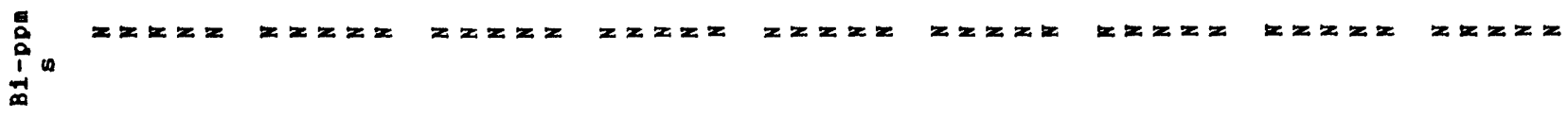

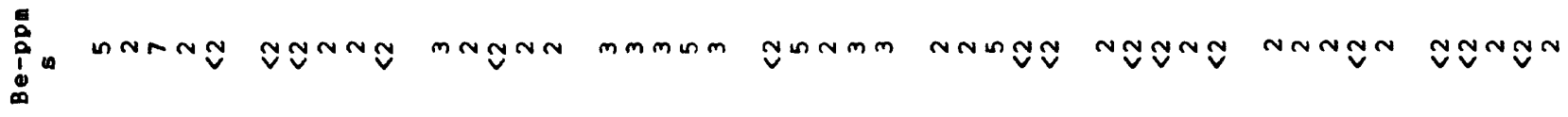

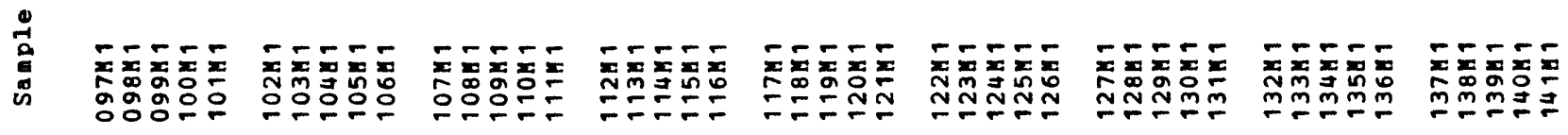




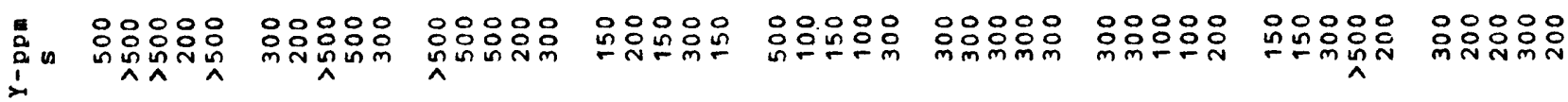

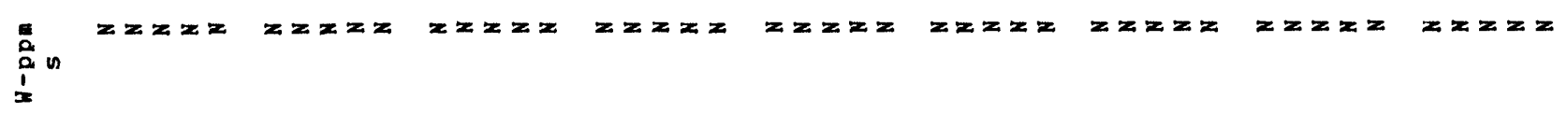

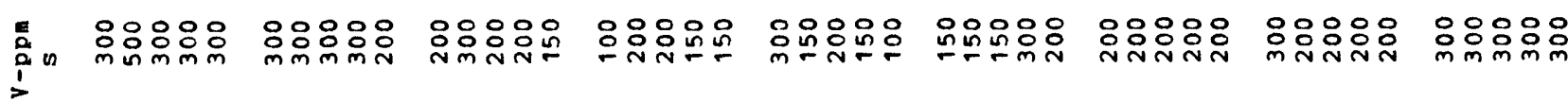

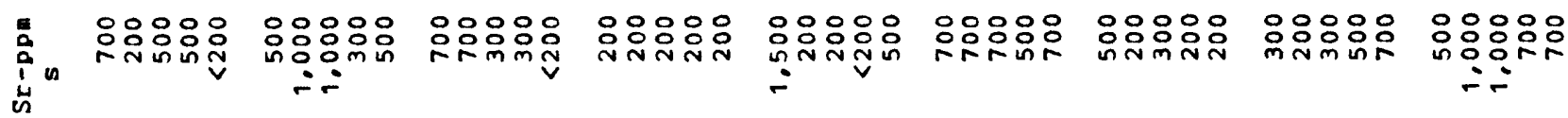

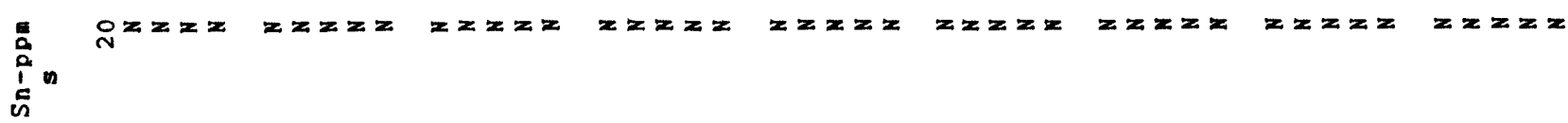

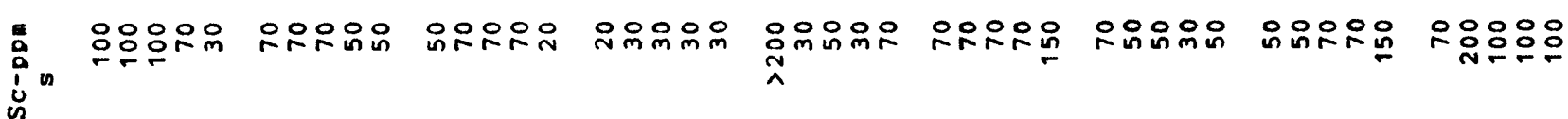
$\dot{3}$ 幽

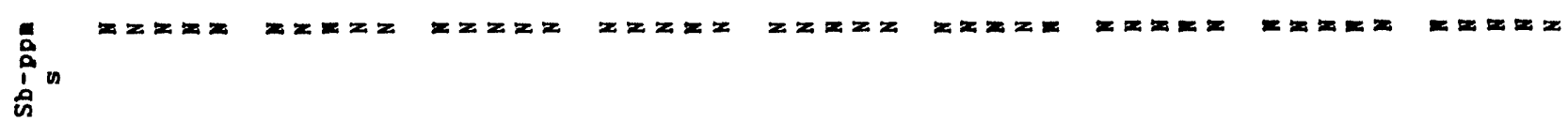

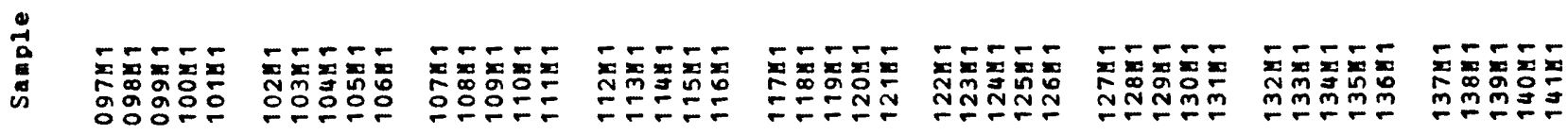




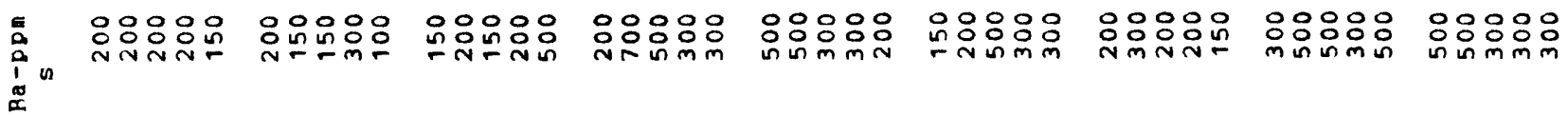

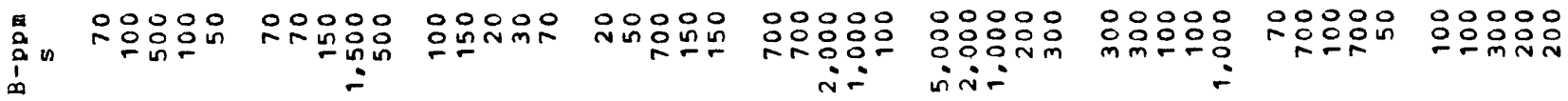

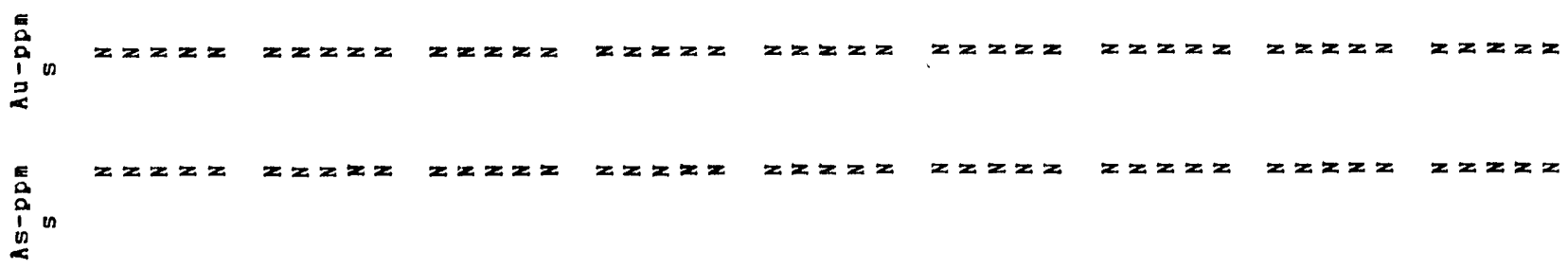

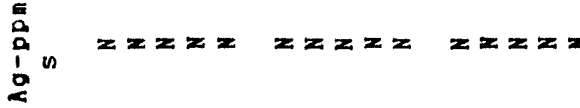

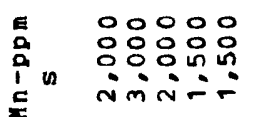

00000

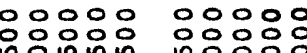

i.i.

$z z z=$

$z z z z$

$z=2 x=$

$z \geq z z$

$\because x z z=\quad z x z z=$ 도

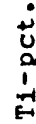

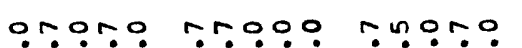

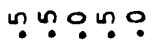

용ำ

กำ? กา

กำ:?

กำก?ำ

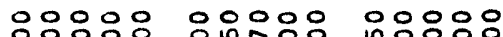

응ㅇㅇㅇㅇㅛ

0000000000

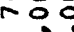

00000

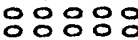

$\because \because \because \because$

0000000000 응영유 응영으은 $\because \because \because i \div$

范 ómin m

í

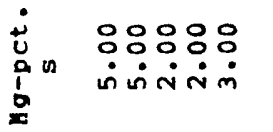

웅요 응요

웅융ㅇㅇㅇ

웅ㅇㅇㅇㅇㅇ웅

웅ㅇㅇㅇ 웅ㅇㅇㅇㅜ ?ำ? กำ กำกำ

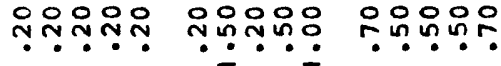

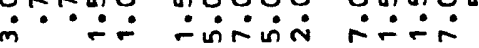

…ㄴ.?

잉요융요

ํํํํํํำ

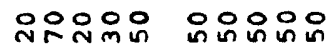

U 00000 0.000 0.000 0.900

0.00 .0

$0.0: 0$

용유

mํํ요

웅유

$\because: 0: 00$

00000 is

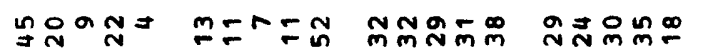

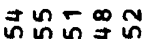

$a \div \stackrel{n}{*} \tilde{m}$

$N \stackrel{N}{N}$

in응

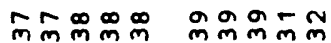

$\stackrel{m}{m} \underset{m}{m} \vec{m} \vec{m} m$

$\bar{m} \bar{m} \bar{m} m_{m}^{m}$

มีกับษ

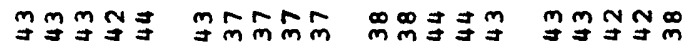

nnun nun

un $\ln$ un

nunun

Nm m m m m m

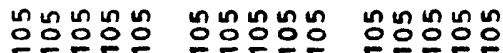

응으응응으

응ㅇㅇㅇㅇㅇ 응ㅇㅇ응

으응ㅇㅇㅇㅇ응

으웅ㅇㅇㅇㅇ 으응ㅇㅇㅇ응

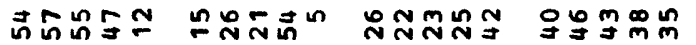

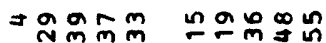

$\min \frac{\min }{\operatorname{mon}}$

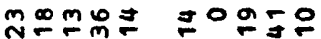

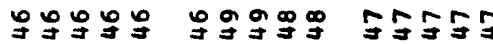

ฐฐฐฐ๋

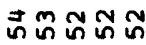

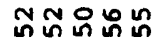

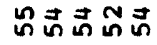

arno

$0-r-n$

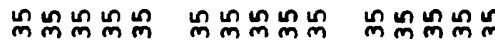

nnmmm

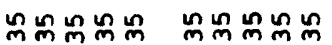

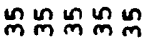

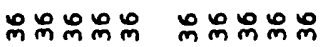

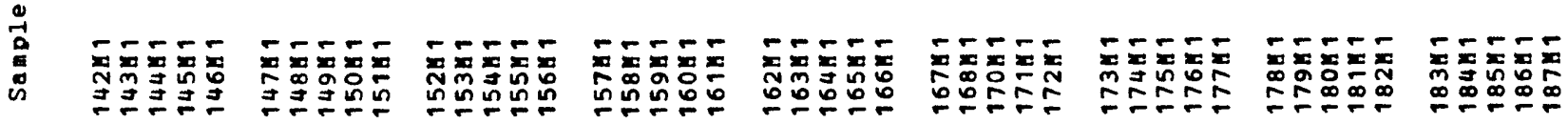


奞

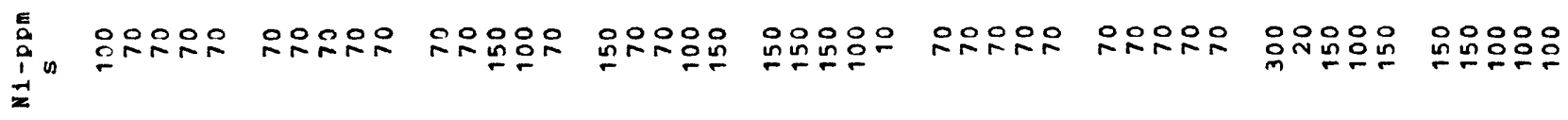

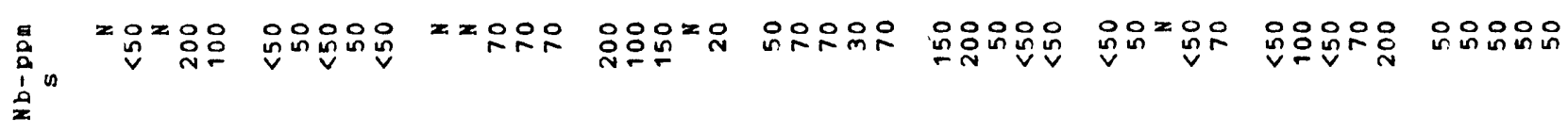

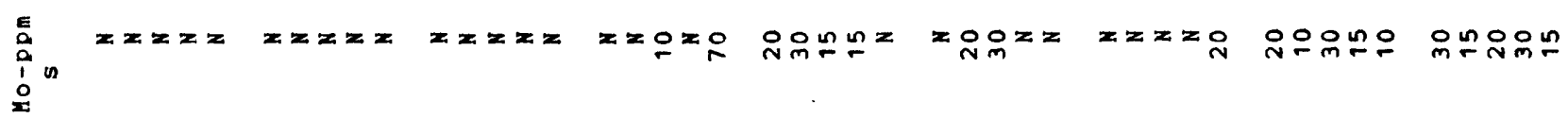

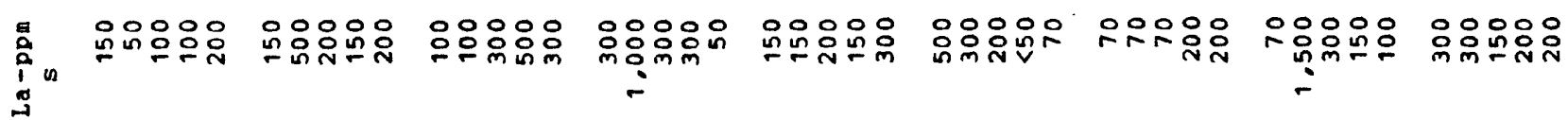

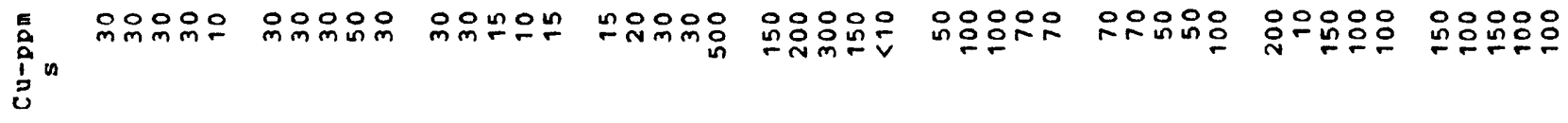

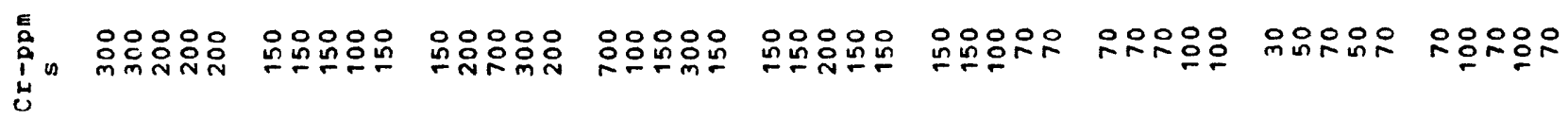

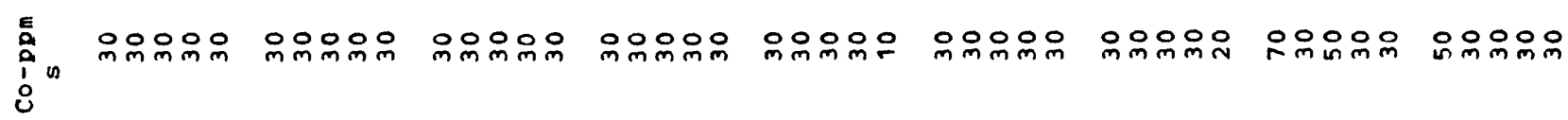

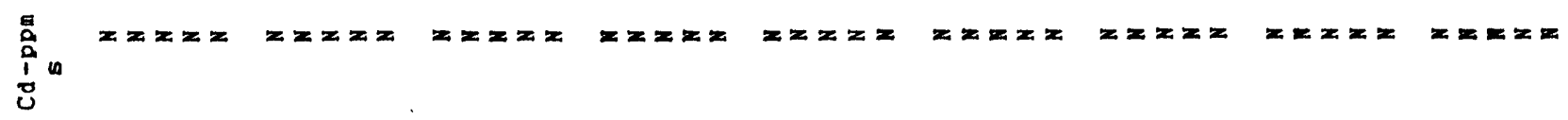

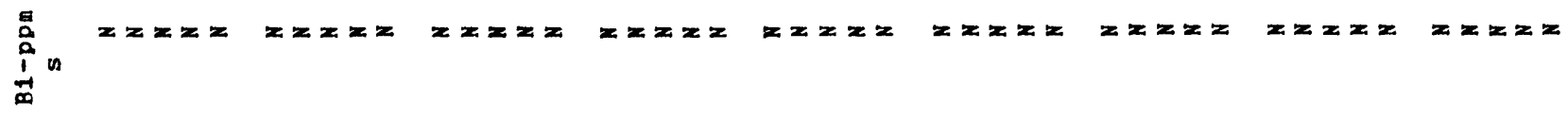

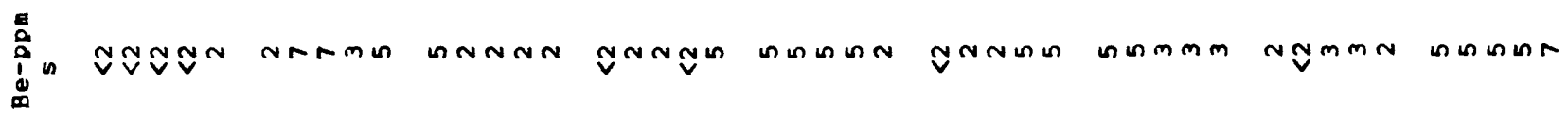

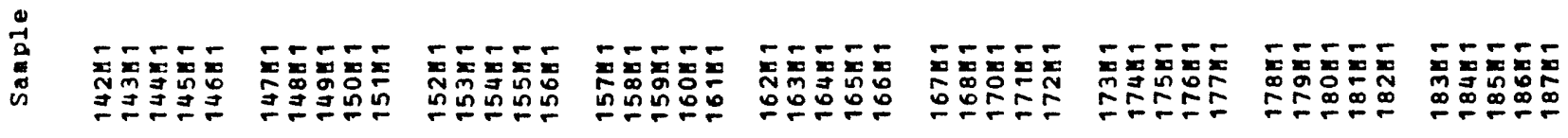




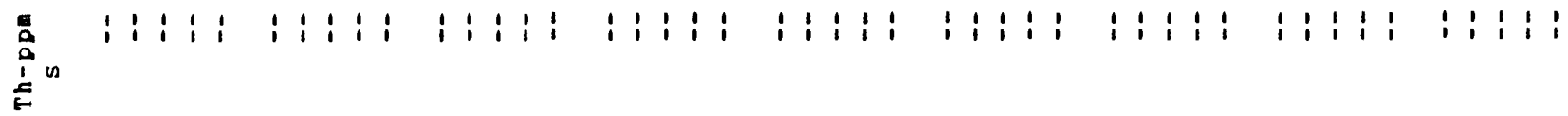

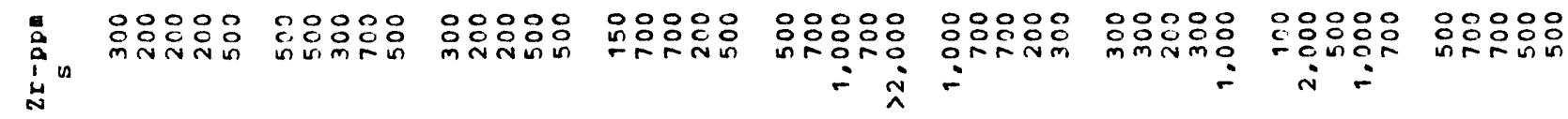

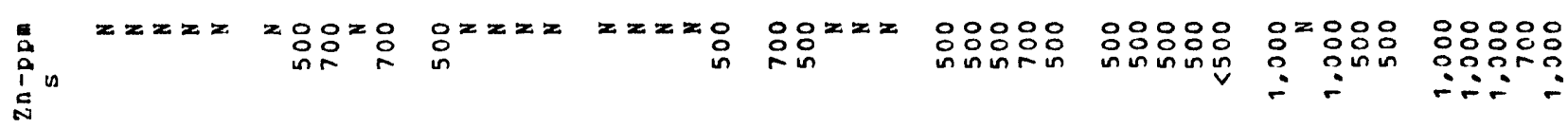

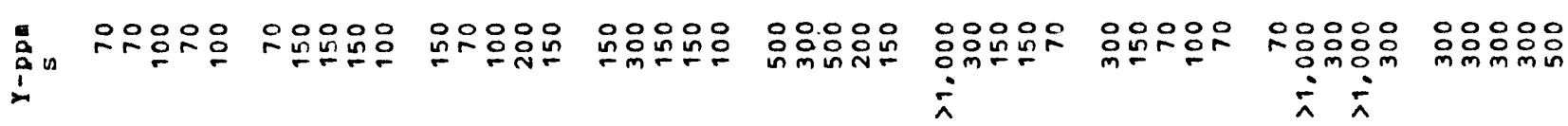

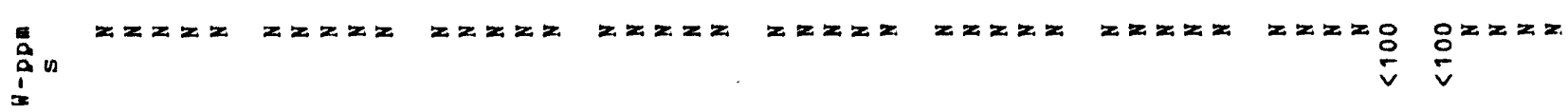

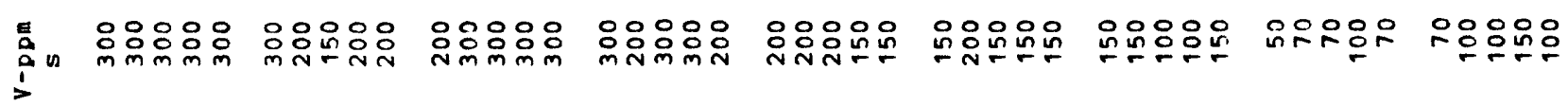

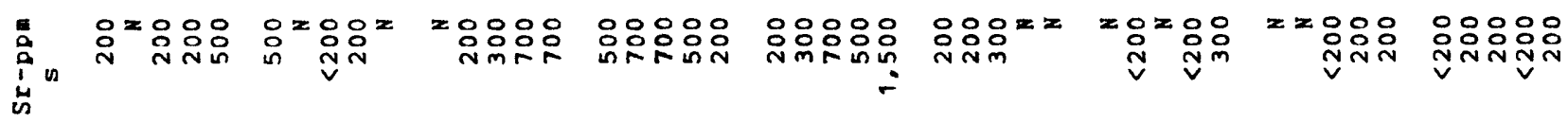

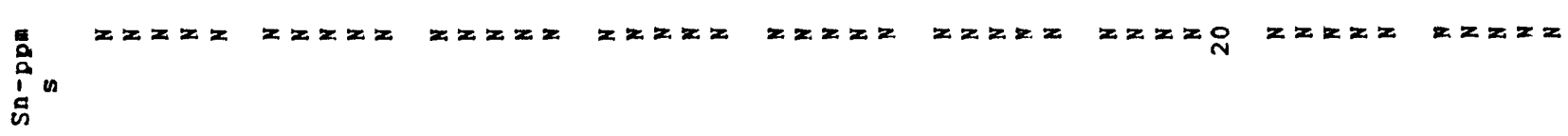

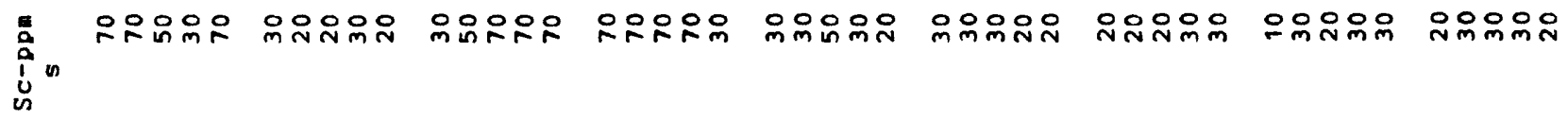

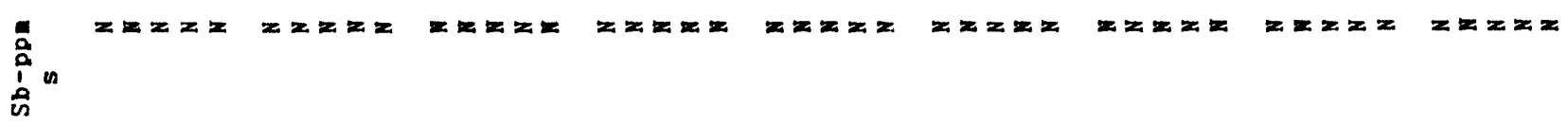

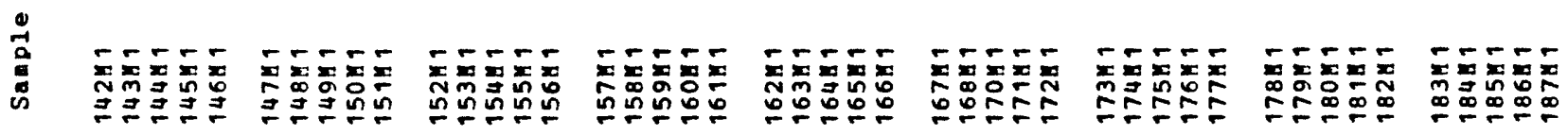




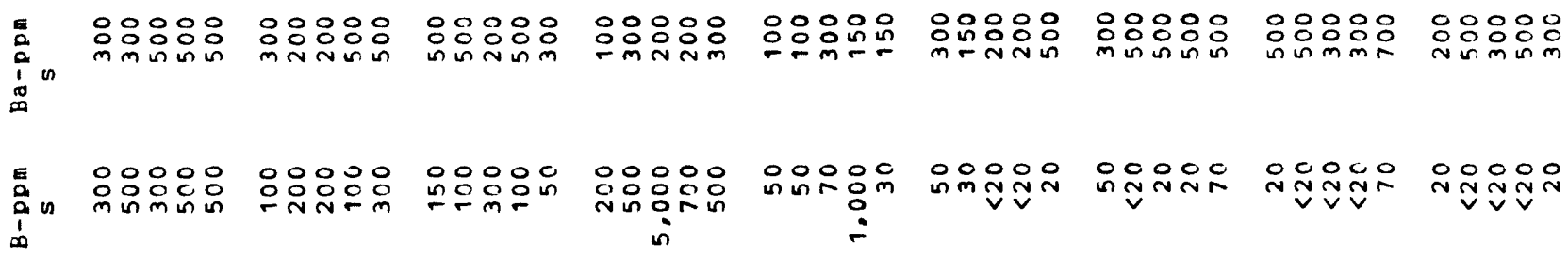

息

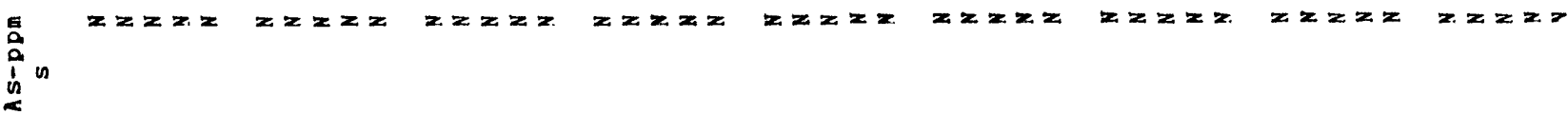

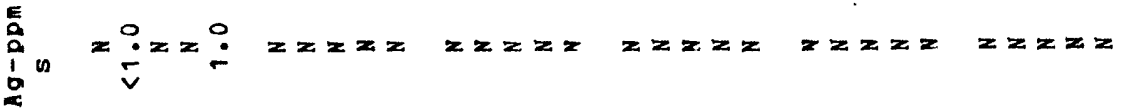

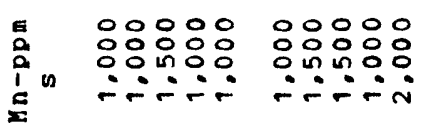
웅ㅇㅇㅇㅇㅇㅇㅇㅇ $\therefore \circ ㅇ ㅇ ㅇ$ in 응용응

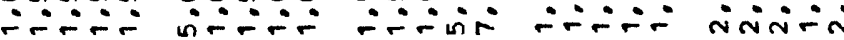

000000

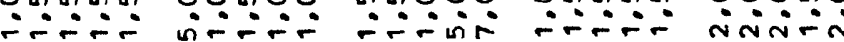

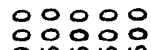

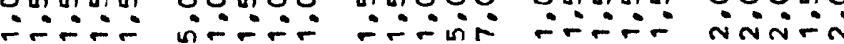

웅ㅇㅇㅇㅇㅇㅇㅇㅇ

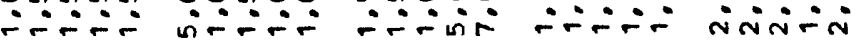

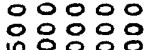
$\because \dot{n} \div$ in

00000 i-ivin iñ

递 $\stackrel{1}{\rightarrow}$

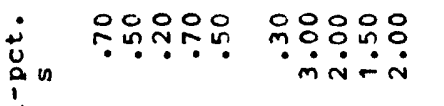

응ㅇㅇㅇㅇㅇㅇ

운우은응

은으눈유 웅유융

응융ㅇㅇㅇ $\dot{\sim} \dot{\sim} \dot{n}$ ini minivi

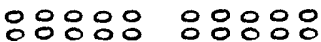

$\ddot{v} \dot{v}$ $\checkmark \cdot$

ini

inimi $\dot{m} \dot{\sim} \dot{N} \dot{N}$

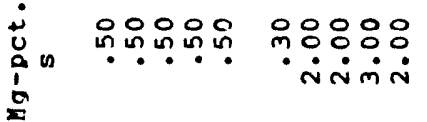

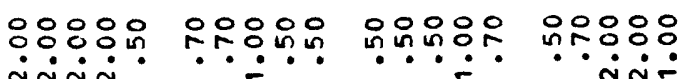

영ㅇㅇㅇㅇㅇ

옹유융용ㅇㅇㅇㅇㅇ응 iัنோ

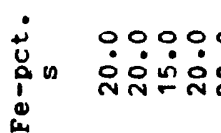

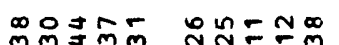

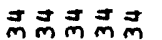

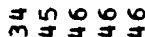

ํํㅇํํㅇํㅇำ

nn nn nn

응ㅇㅇㅇㅇㅇ응

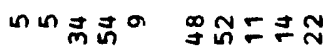

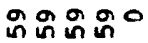

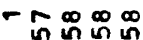

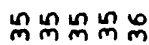

กำ $\sim \infty \infty \infty$

⿰幺𠃌 nn 응ㅇㅇㅇㅇㅇ응

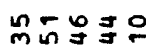

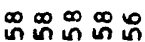

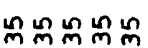

于우의요

웄도옹

ํํㅇํํㅇํㅇㅇㅇㅇㅇ

ำกำ

읐욲융요

nn nn n

웅ㅇㅇㅇㅇ응

ํำกำำ

on in

约药领只

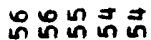

胹觜品

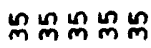

00000

ónir
$0: 0: 0$ rinun
:우웅 ถ

0000

o이

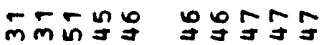

oำㄴำ

N $\simeq$ am

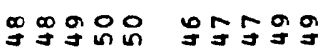

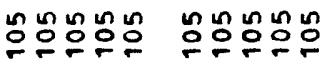
웅ㅇㅇ으응 ํํㅇㅇㅇ융유응

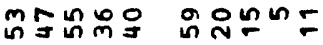

Mำกำ ถกำ

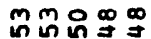
열월ㅇ

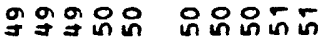

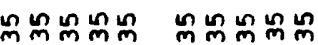

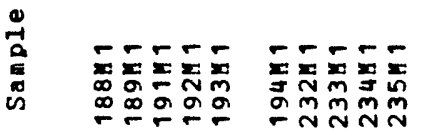

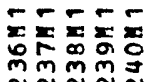

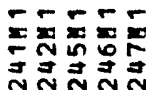

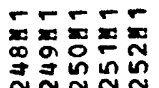

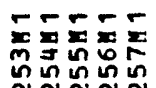

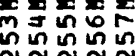

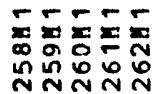

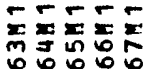

뉸유

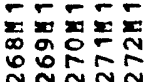




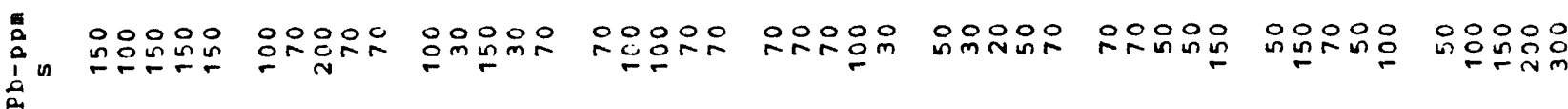

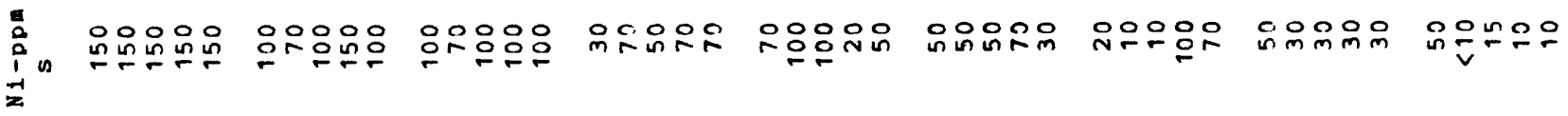

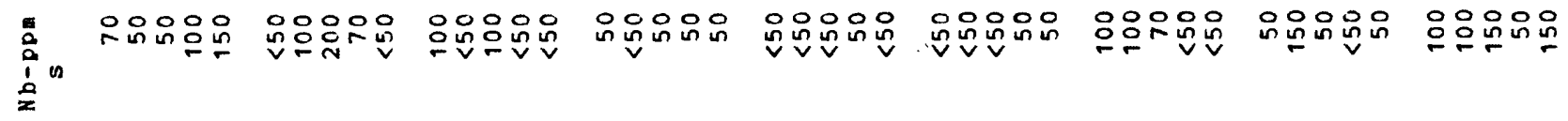

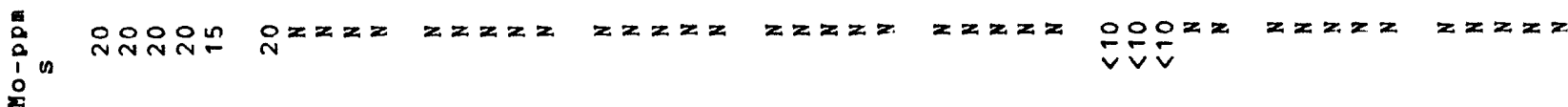

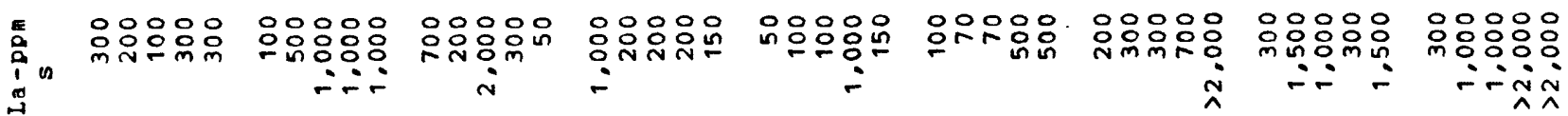

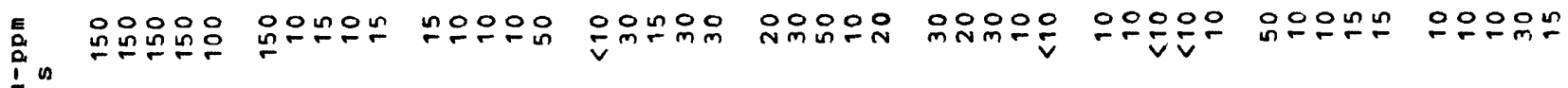
$e^{1}$

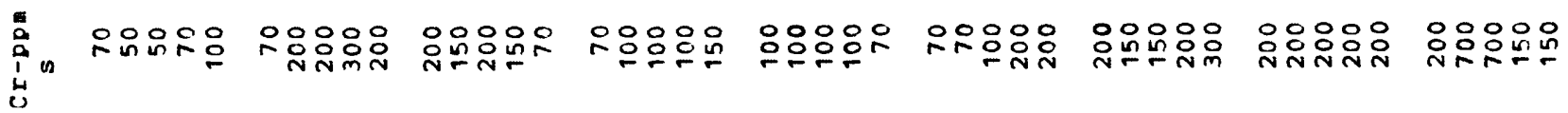

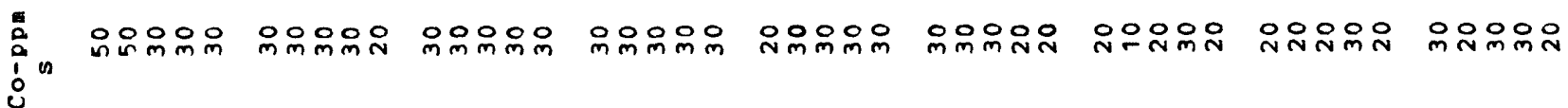

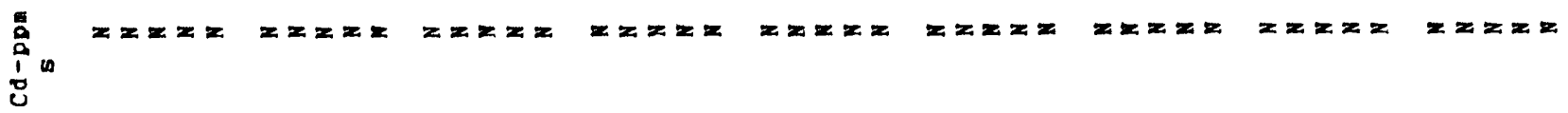

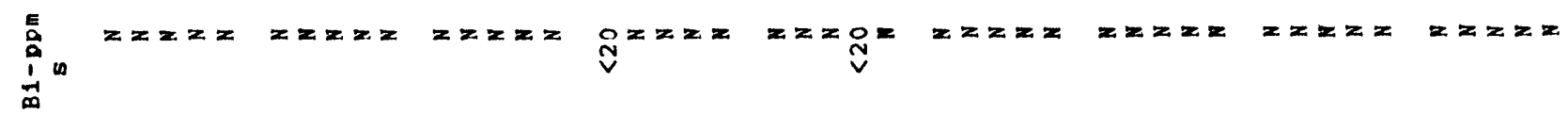

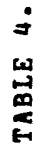

dis

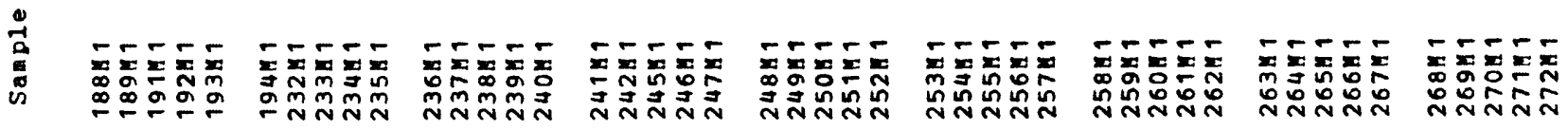




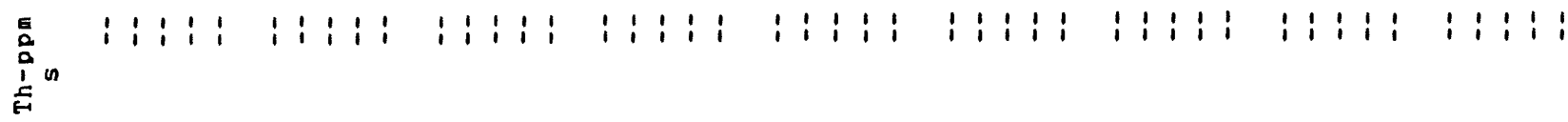

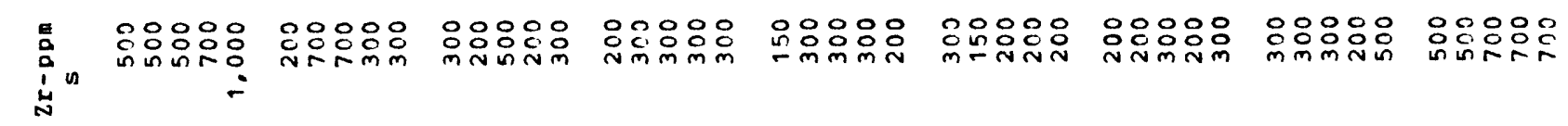

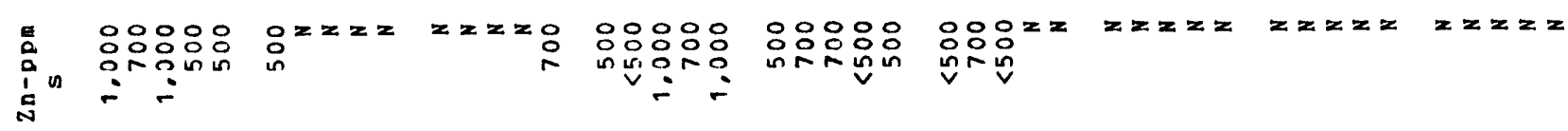

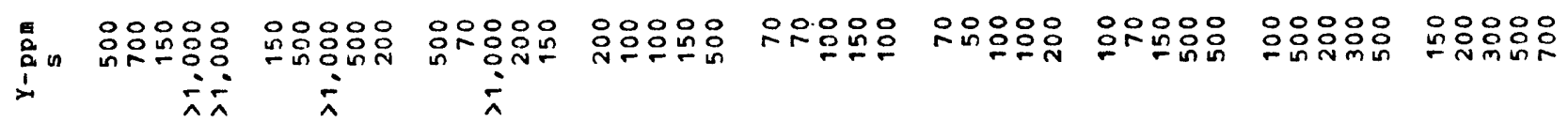

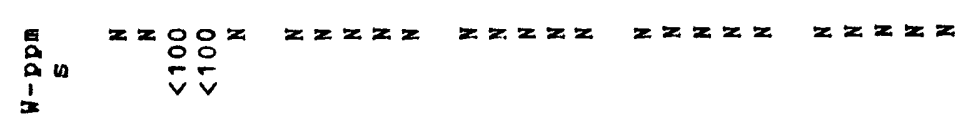

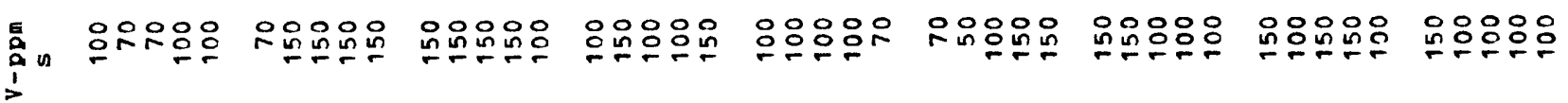

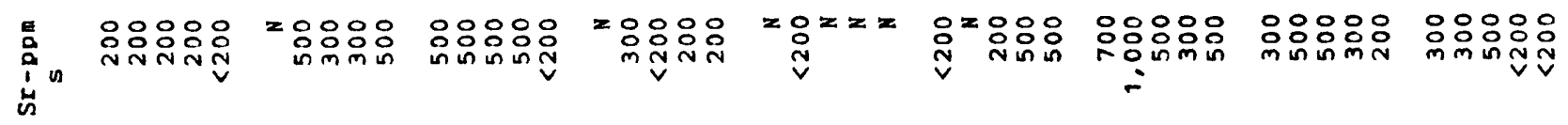

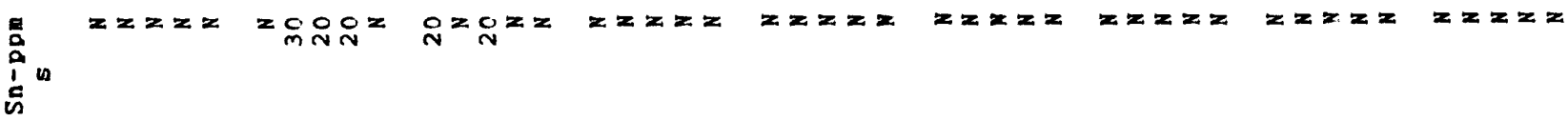

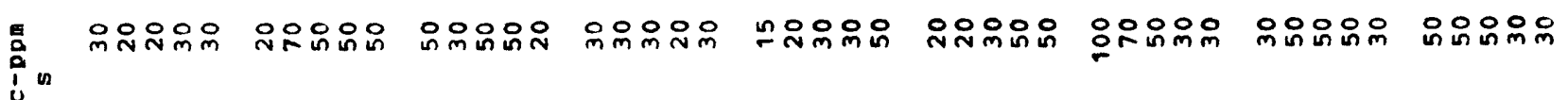
$i^{\prime}$<smiles>C#CC#CC#CC#CC#CC=C=C=C=C</smiles>
$z z=z \quad z=z=$ $x=z=2$

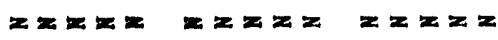

崰 


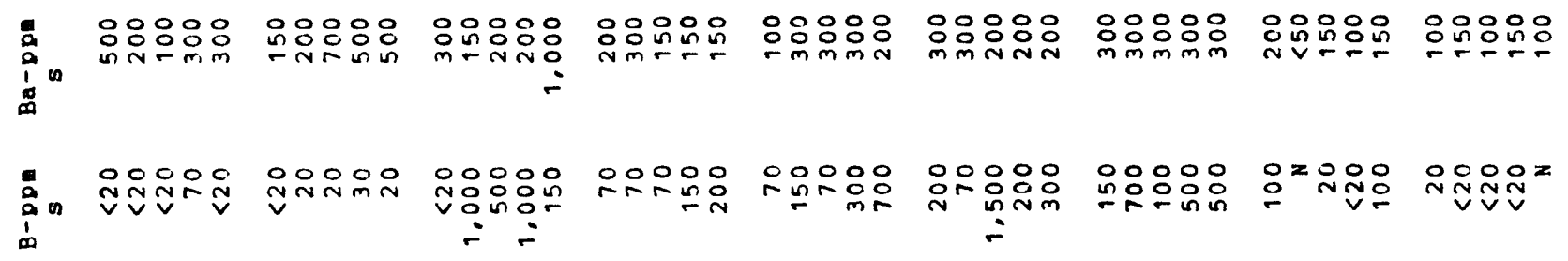

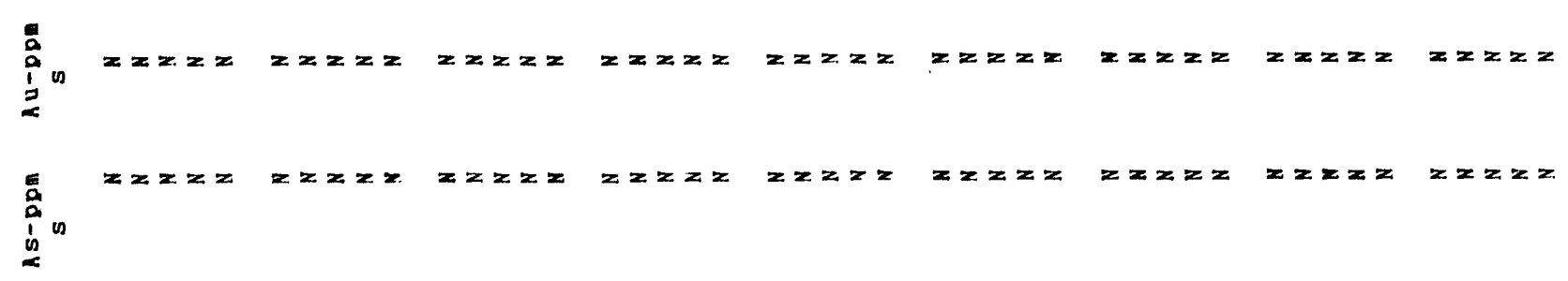

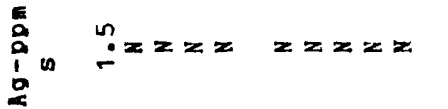

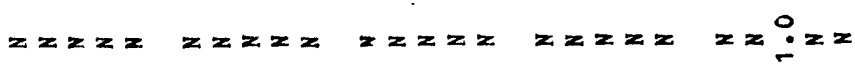

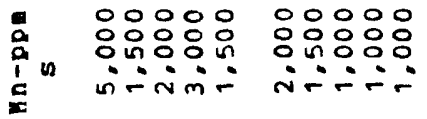

응응응 응응응 응응응

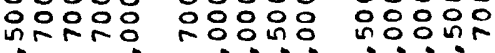

$\because \because \because$

$\because \because \because$

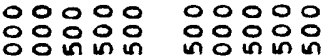

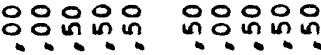

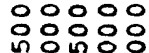

응응응

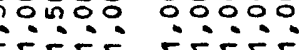

ช

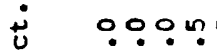

oodon

$m$ m

$\therefore-$

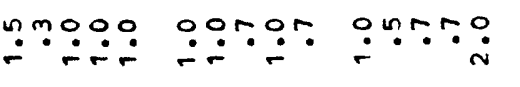

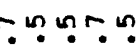

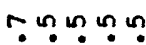

m. ํ. 응

$\because \because 90 \%$

$\sum_{-1}^{2}$

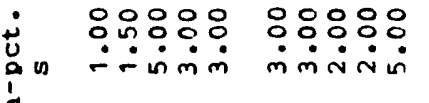

응옹유유

은응은유운

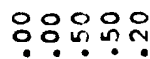

위ํ응ㅇㅇㅇㅇ

inim

유늉ㅇㅇㅇㅇㅇㅇ

- iñ

응ㅇㅇㅇ음

त่ن่

응용ㅇㅇㅇ응

离

苞的

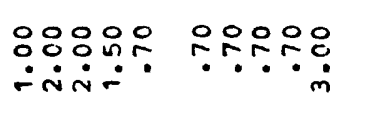

온유윰유

응응ㅇㅇㅇㅇ

응융엉오

억용ㅇㅇ응

응영영응

응응응요

응영응ㅇㅇㅇ

造电

00000

:00:0:

00000 $\because \because \therefore$

$\dot{m}$

ivi

$\because \because \dot{i} \dot{m}$

Nंत्रm-

- $\dot{\sim} \dot{n} \dot{m}$

inisi

जिंगं

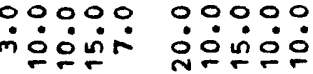

00000

0000000000

00000

00000 is

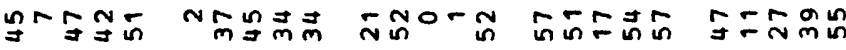

制

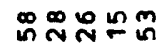

in

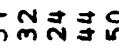

Nmm mm $m \vec{m}$

$n m m m m$

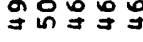

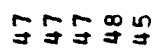

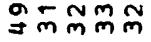

กำกm $\underset{m}{m} \stackrel{m}{m}$

ติ

แnunn

nnn nn

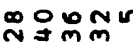

을소을

능융ํㅇ유융

뉴은응요융

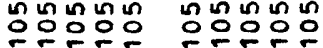

농ํํ융ํㅇํํ

응으응으의

우융ㅇ유웅

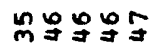

ฐすษきす

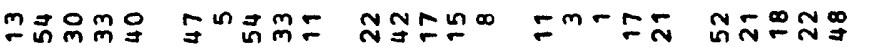

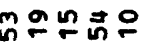

$\operatorname{ogg}=$

กำกำ

กnกnกn

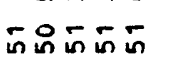

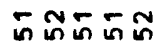

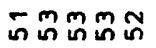

กิก ถูกิก กิ

in

용요용

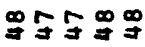

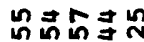

윤ํํ요

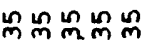

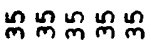

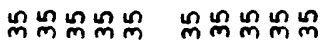

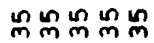

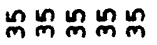

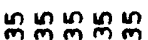

可寻寻吉

99999

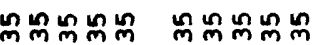




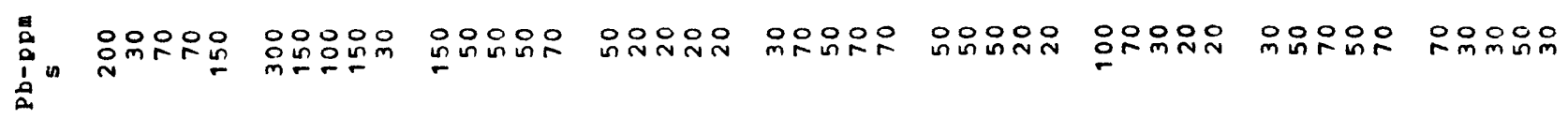

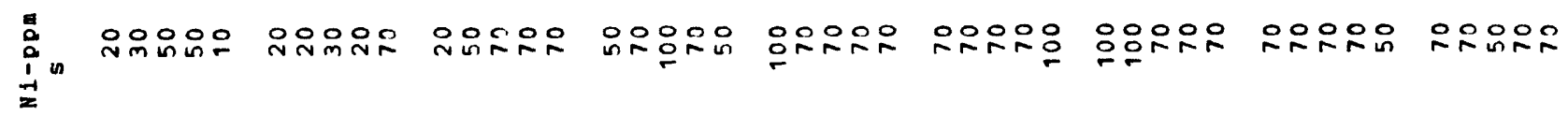

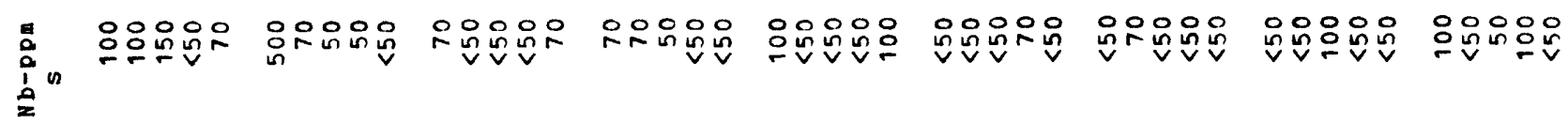

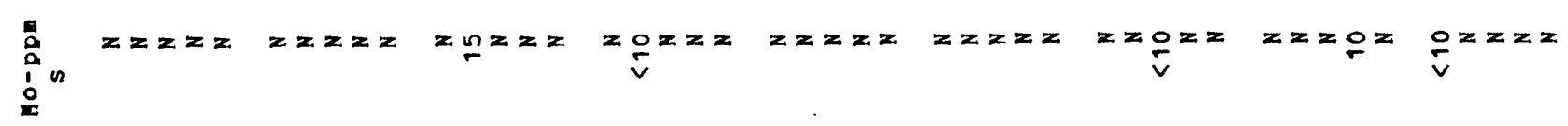

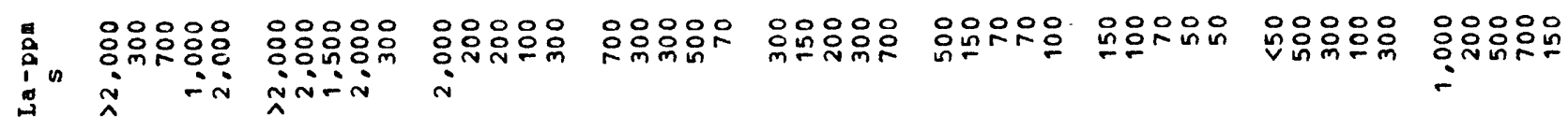

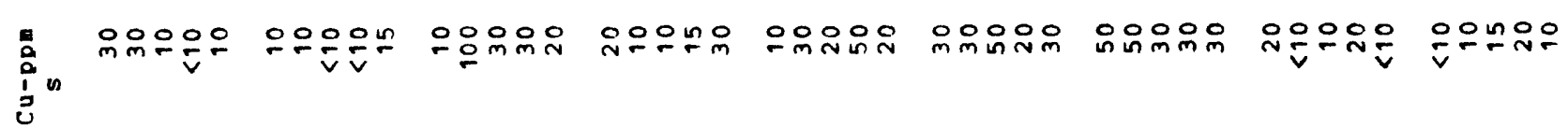

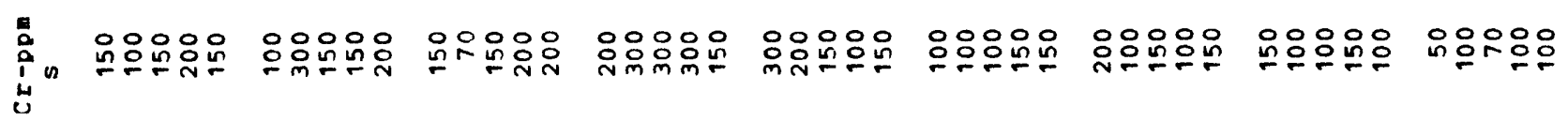

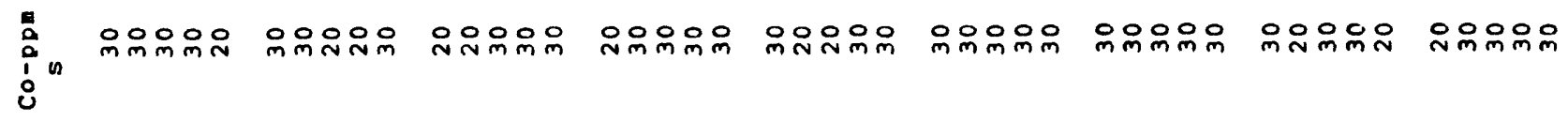

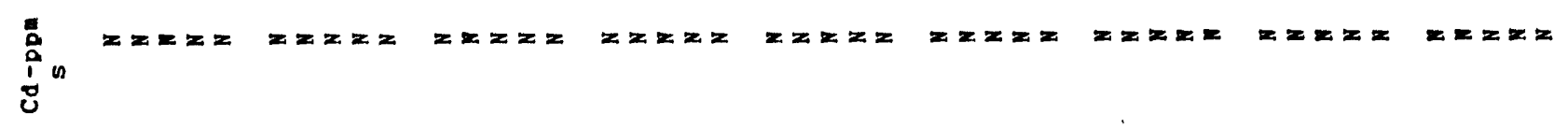

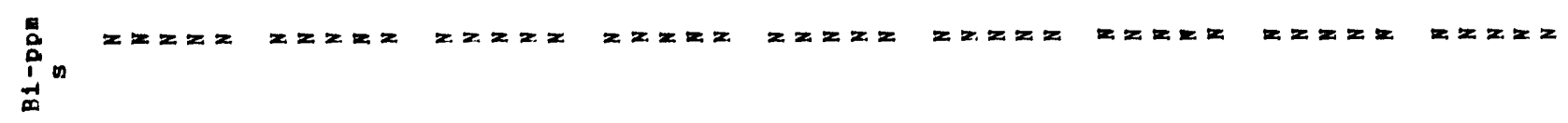

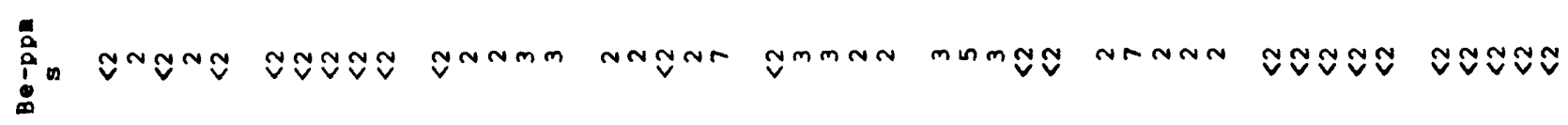

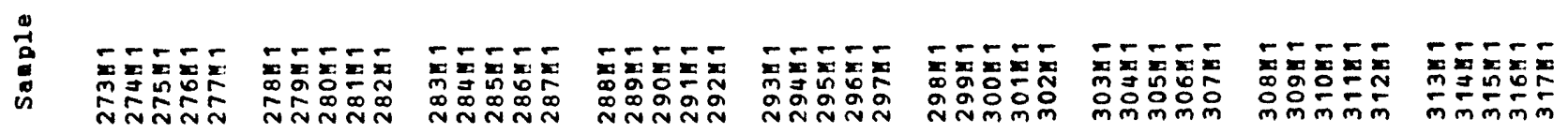




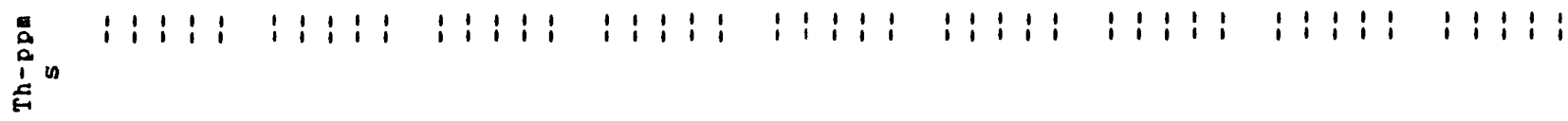

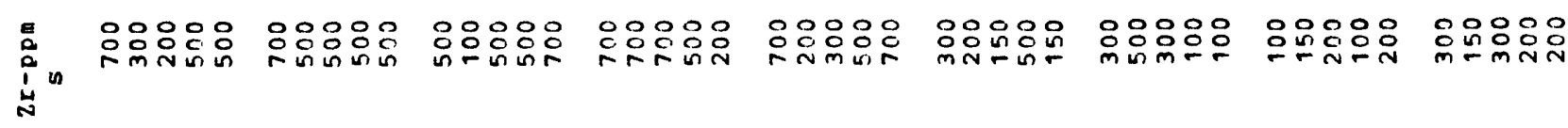

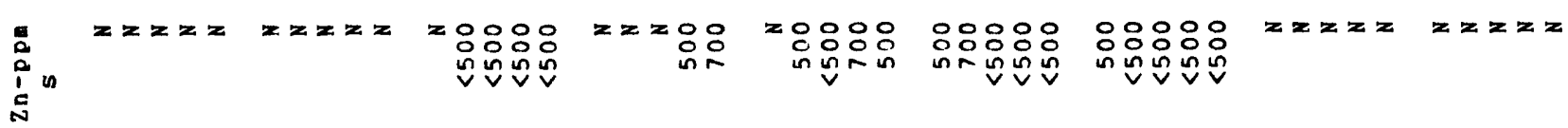

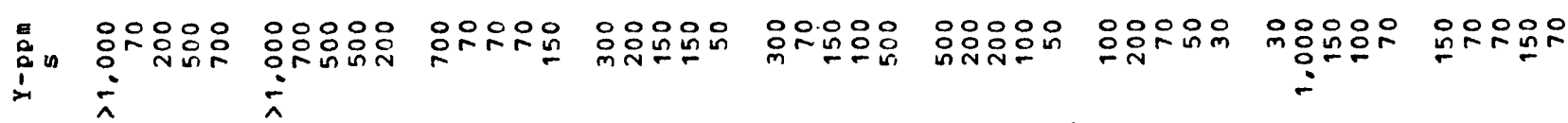

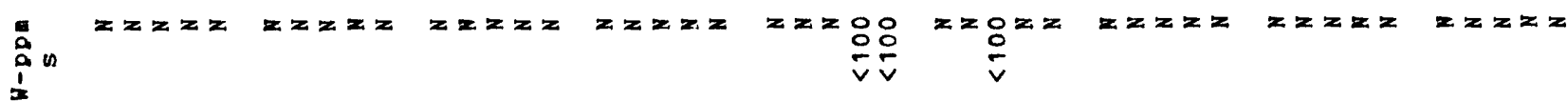

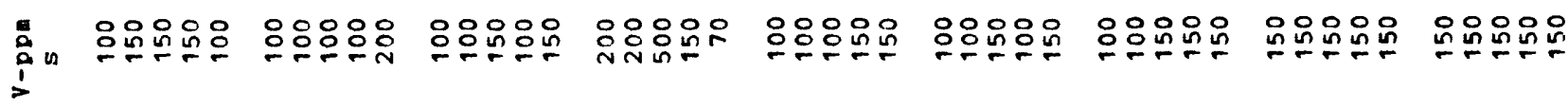

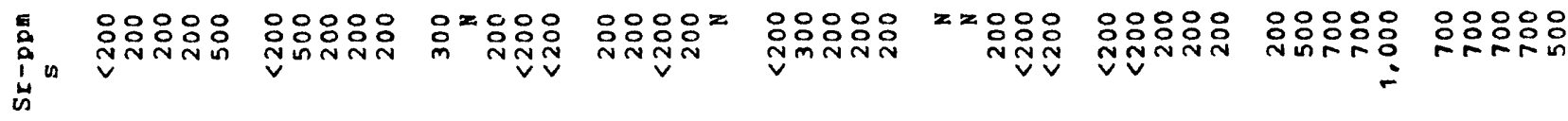

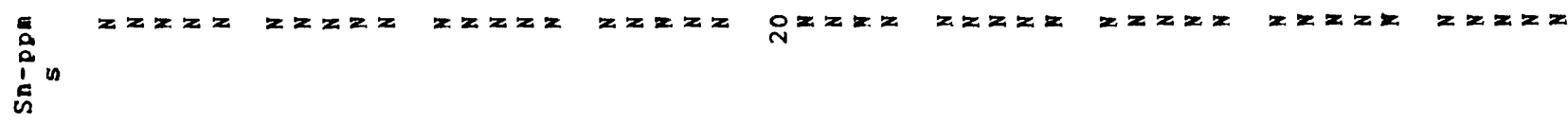

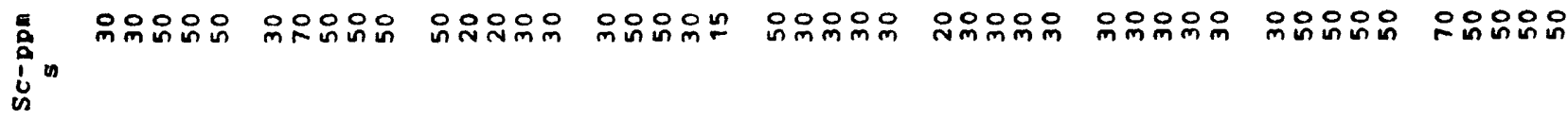

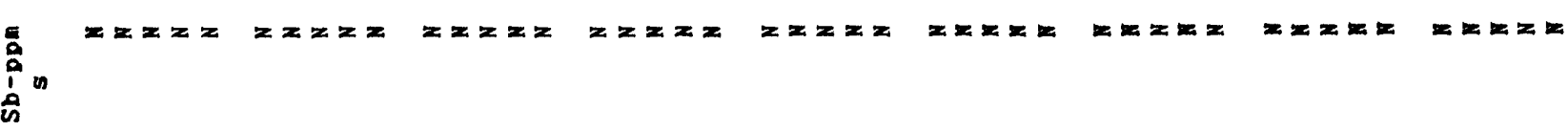

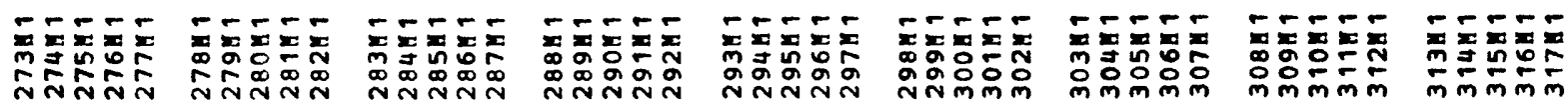


a

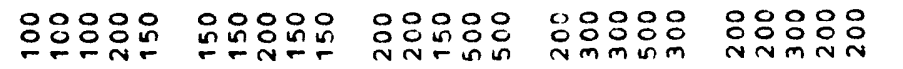

in

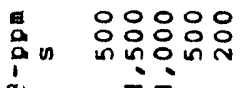

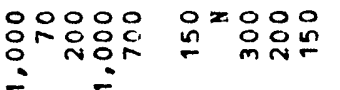

00000

응응ㅇㅇㅇㅇㅇ

은으은응

inmor

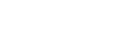

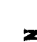

$a$
0
0
$\vdots$
2

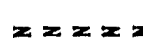

$z z z z$

$z=2 z$

$z z z$

$x z z z$

$z z z=$

$z x=2$

$z z z z$

$z x z z=$

$z=2 z$

$z z=z$

$z z z z$

$z z z z$

$z z z z$

$z z x z$

$z z=2$

$z z=z$

$z z_{2} z$

in

$<$

$z z z z$

$z z z z$

$z x z=$

$z z z z$

$z x z=2$

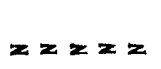

$z=z$

$z z 2 z$

$x z 2 z$

2

a

\section{응응으 응응응

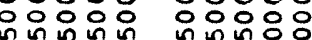

$\because \div ?$

$\because \div \div$

옹응ㅇㅇㅇ

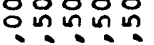

응ㅇㅇㅇㅇㅇㅇㅇ

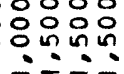

응응응응

응영ㅇㅇㅇ응

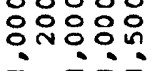

응응웅응

00080

응ㅇㅇㅇㅇㅇㅇㅇㅇㅇ

$\because \because \because-$

$\because \therefore \div$

00000

웅용ㅇㅇㅇㅛ

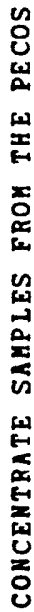

䓪

$\operatorname{nnm} n \sin$

$h r h r$

rara

$\ln n 000$

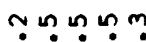

m:?m?

ค.?.ร

คำ? ดทำ

e-

\section{응ㅇㅇㅇ융ㅇㅇㅇㅇㅇㅇㅇㅇ}

응응ㅇㅇㅇ

융응ㅇㅇ응

जिं $\operatorname{cin}$ in

in-ن்

응ㅇㅇㅇㅇㅇㅇ

$\dot{n} \dot{1} \dot{0}$

응ㅇㅇㅇㅇㅠ

융ㅇㅇ

영응ㅇㅇㅇ

응ㅇㅇㅇ응

i

กัน

ث 옹용용 응응응응

00000

응ㅇㅇㅇㅇㅇㅇ

응ㅇㅇㅇㅇㅇㅇ

은응용

영융응

응ㅇㅇㅇ응

응융ㅇㅇㅇㅇㅇㅇ

in

inimi

imín் mí-

- $\dot{\sim} \sin$

- $\dot{m} \dot{m} \dot{m}$

minisin

rinmi

ín்

苑

00000

00000

웅요

00000

00000

00000

00000

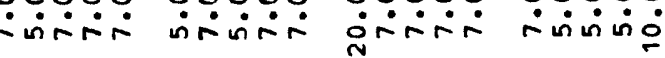

n்

ninn

$\operatorname{rro}$

00000

OON-

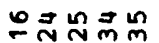

กูำ

in $\stackrel{0}{9} g$ in

ํำ

$\exists \vec{N}^{\circ \infty N}$

이는

โ

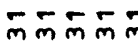
다이이요

을웡응

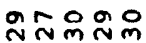

응임웜

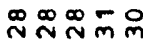

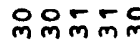

ㅇํำ 뚠

농ํㅇ응응응

ํํํํํㅇํํㅇํㅇ

ํํㅇํํㅇํํำ

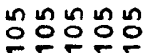

드응으응응

ํํㅇํํㅇํㅇㅇํㅇ

ํํㅇํㅇㅇ융

ํํㅇํํㅇํㅇำ

N $\stackrel{\infty}{\sim} \backsim$

$\stackrel{m}{=}$

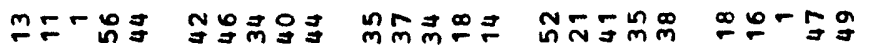

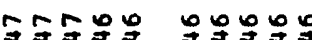

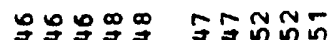
的舟罗要

जี००ᄋ

ีำํำำ

กำํำกำ 응응ㅇㅇㅇ응응

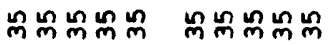

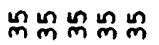

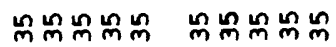

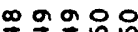

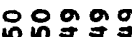

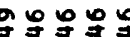

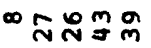

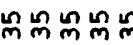

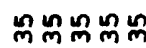

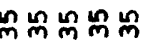

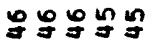

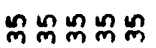




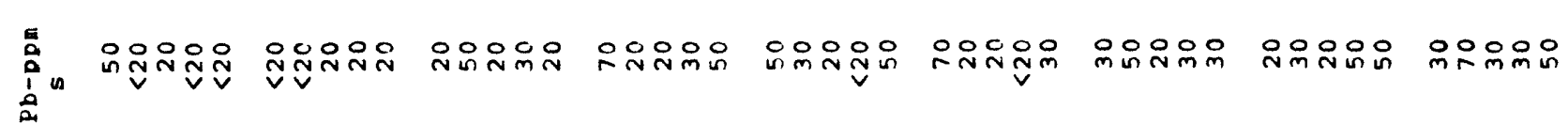

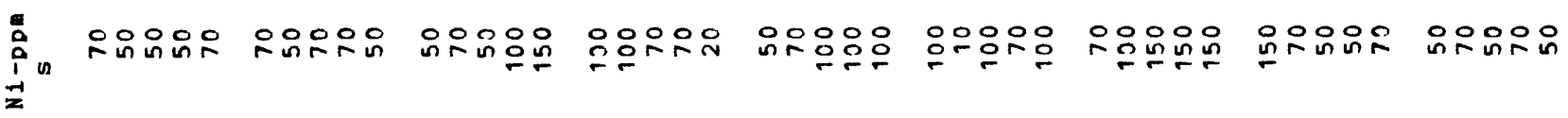

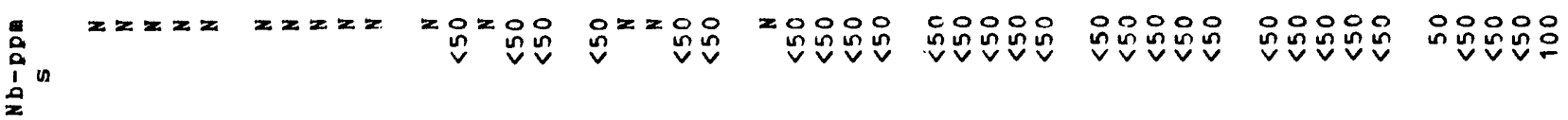

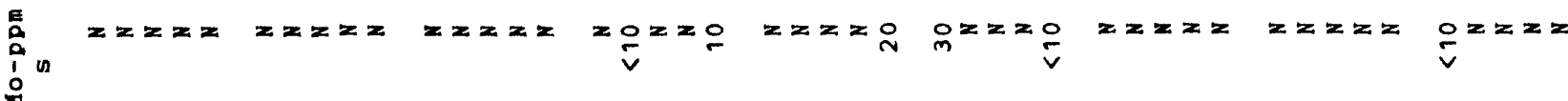

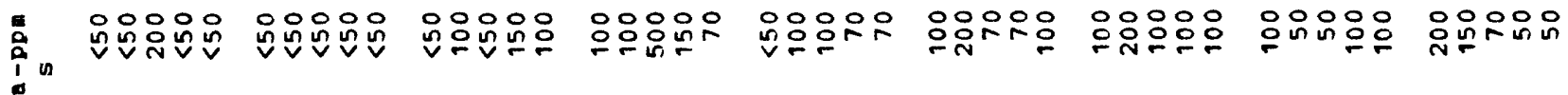
$\unlhd$

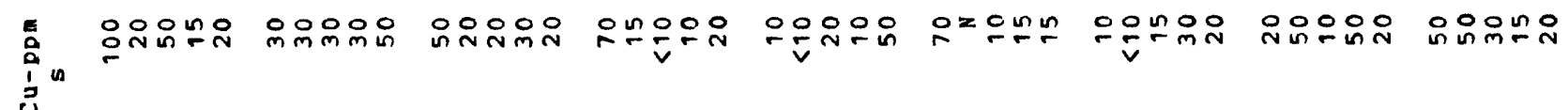

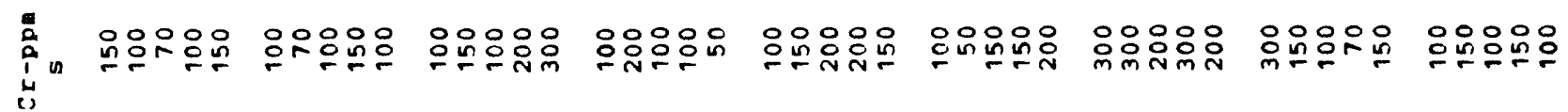

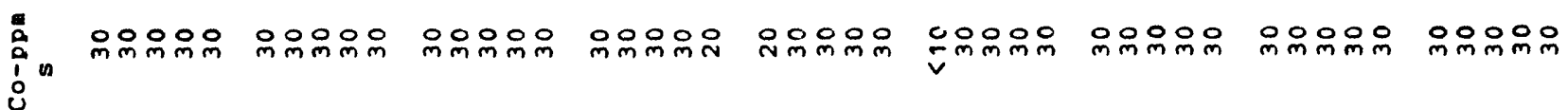

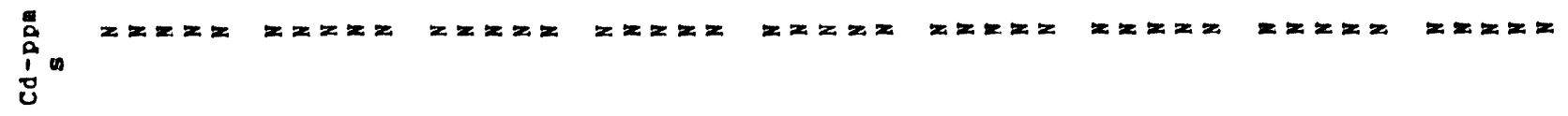

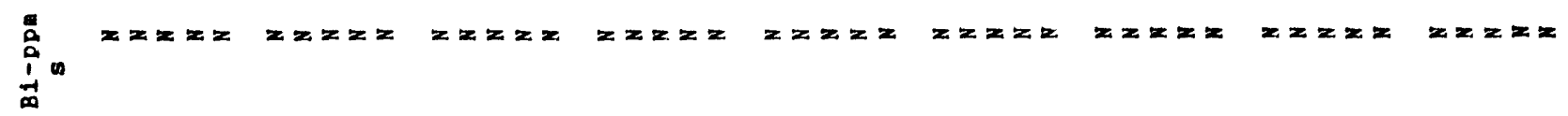

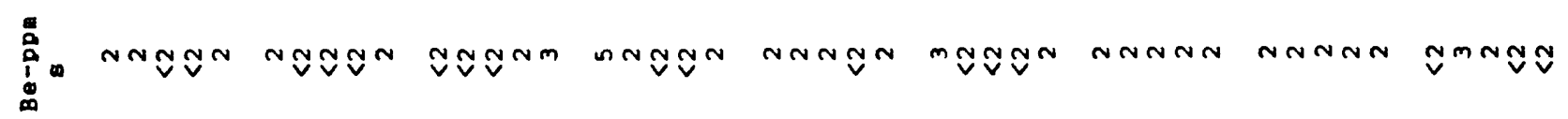

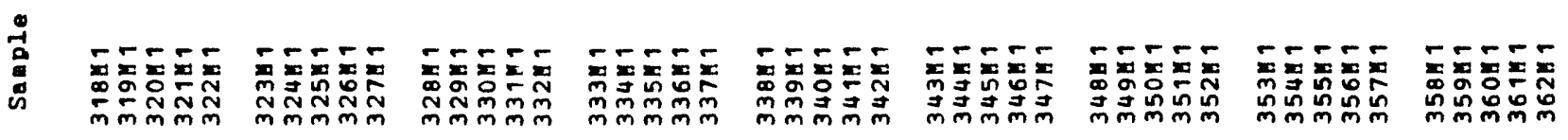




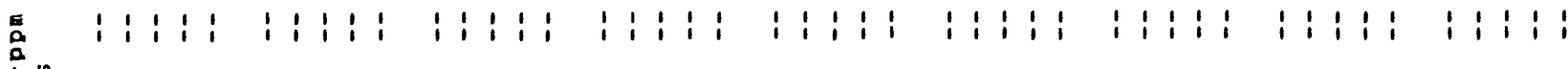
in

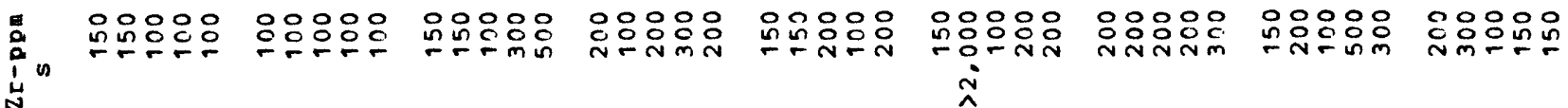
空象

요 $z=x=$

$O^{2}=x z$

$z=z=0$

in

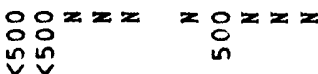

o oopo orion

00000

응응으웅요

은오은응은

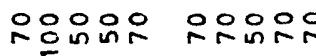

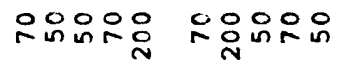
$\frac{1}{2}$

$x z z=x$

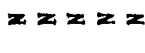

$z z z z$

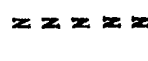

$x z=x=\frac{g}{g}=z$

$z=2 x$

$z z z z=$

$z z x z z$

10

总里

0000

\section{응응용으 응웅응요}

으응응응

은요은으ㄴㅗㅛ

옹은은응

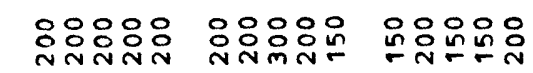

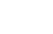

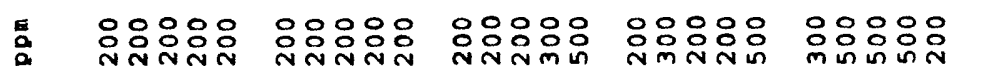

in N N

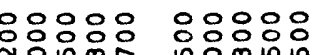

Nongr ing

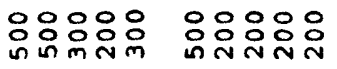

罢

范

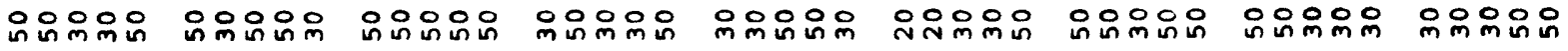

$$
\text { is }
$$

$z z z z z z z z z$

$z z z z$

$z=x=$

$z z z z$

$z z z z$

$z=z z$

$z z z z z \quad z z z z$ in

$$
\sqrt{2}+n^{2}
$$

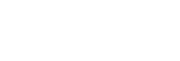

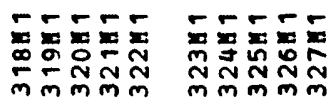

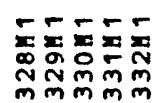

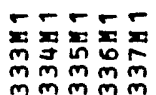

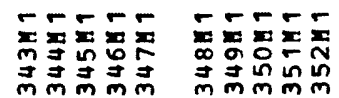

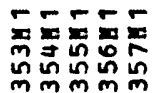

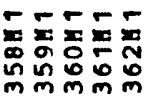




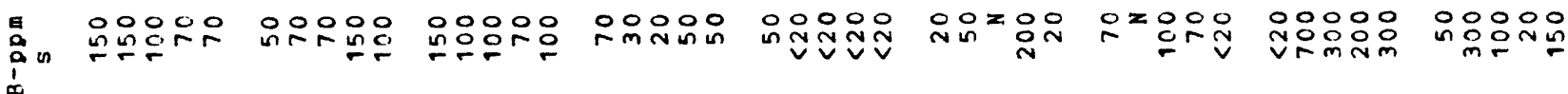

$\stackrel{5}{a}$

$z z z z$

$z=2 z$

$z=x \geq 2$

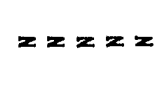

$z z z=$

$z x=2$

$z z=2$

$z z z z z \quad z z z z z$

总

$z z z z z \quad z z z z z \quad z z z z z$

$z x=2$

$z=z=$

$z x z z$

$z z=2$

$z z z z z \quad z z z z$ in

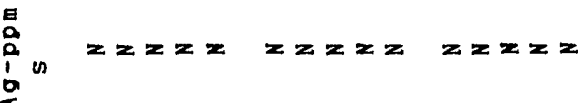

$z z z=$

$z z z z=$

$z z z z$

$z z z z$

$z z z z \quad z z=z z$

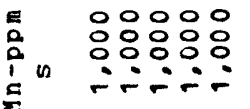

응영응

00000

웅ㅇㅇ

经织的

in in in:

$\because \div$

$\because \because n$.

000000

응요융요

웅ㅇㅇㅇㅇㅇㅇㅇㅇ

응영응응

0000000000 …

莕

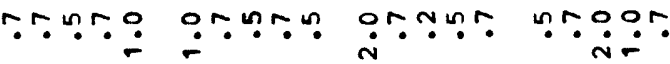

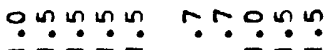

$\stackrel{9}{0.090}$

$\because \because 0 \div \because \div 0 \div \div \div$

ar

苍

응ㅇㅇㅇㅇㅇ응

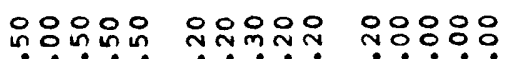

융ㅇㅇㅇㅇㅇ

응ㅇㅇㅇㅇㅇ जinin

- $\dot{m}$ in

nं $\dot{1} \dot{1} \dot{1}$

영ㅇㅇㅇㅇㅇ

영융용

$\dot{m} \dot{m} \dot{m} \dot{m}$

nंrí

은용ㅇㅇㅇㅇㅇ نั

\begin{tabular}{l}
\multirow{4}{*}{} \\
0 \\
$\vdots$ \\
0
\end{tabular}

\section{응ㅇㅇㅇㅇㅇㅇㅇㅛ}

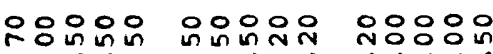

웅응으움요

응융ㅇㅇㅇㅇㅇ

$\because \because \cdot$.

$\because \because \because \dot{\circ}$

응영응요

$\dot{i} \dot{n} \dot{0}$

응응요은 은

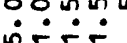

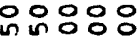
ininis

(1)

苔n

0000000000

0.000

0000000000 minimi nisin

nisin

ம்日்

\section{융ำ웅}

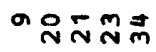

ํㅜㄴํํำ

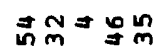

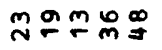

$\stackrel{\infty}{m} \stackrel{\infty}{m}$ 울

ํำㄴํํำ

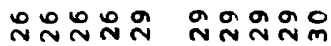

을으웜ㅇ

i̊n

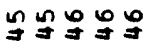

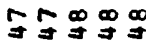

능응으융응

ํํำํํำ

ํํㅇํํำำ

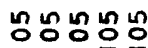

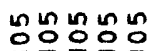

ำํํㅇํㅇํํㅇ

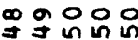

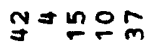

푸요의 0

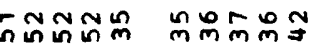

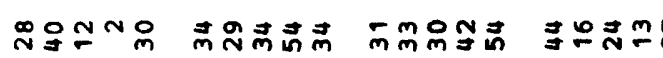

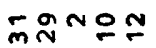

눈요워

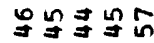

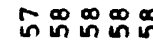

ํํํํํํํํำ

ํㅗำ ํํำ

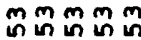

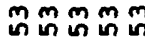

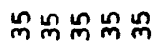

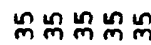

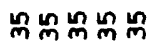

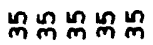

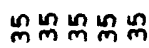

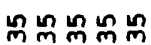

ํํㅇํํㅇํㅇ

nn un

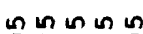

응ㅇㅇㅇㅇㅇㅇㅇㅇㅇㅇㅇㅇㅇ응

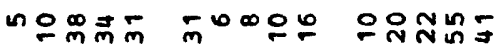

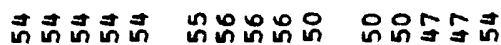

กㅆำ

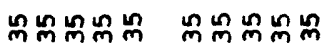

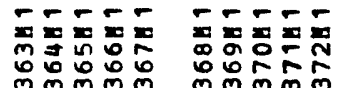

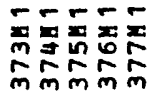

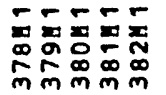

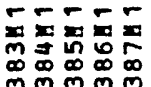

部的 مَำ

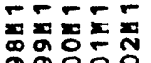
ingiogo

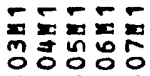




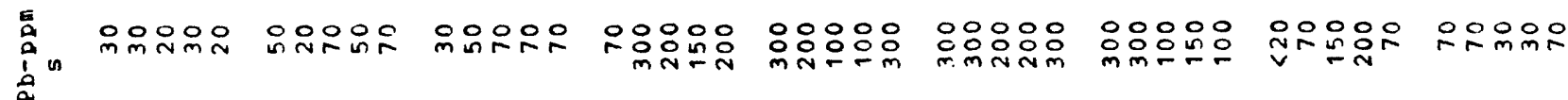

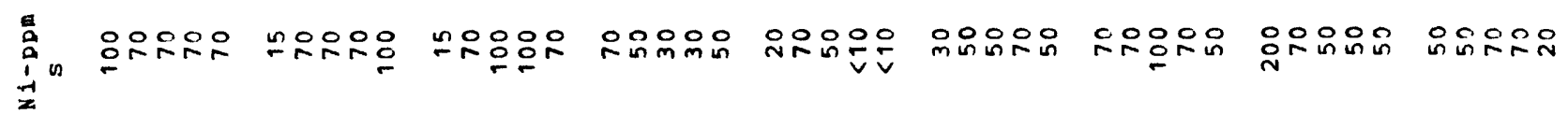
ํํำ $\stackrel{1}{2}^{2}$

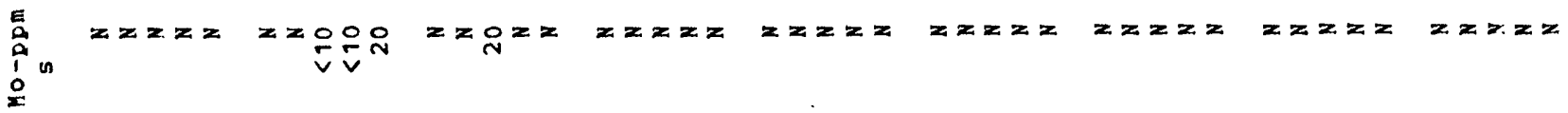

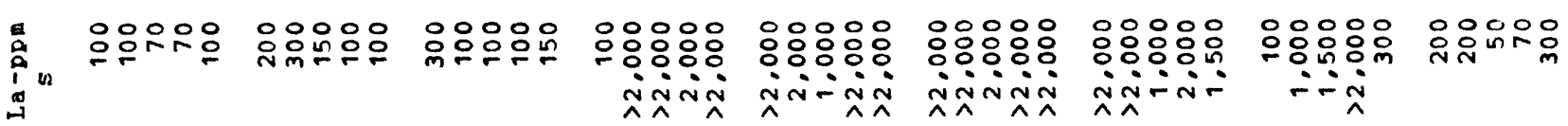

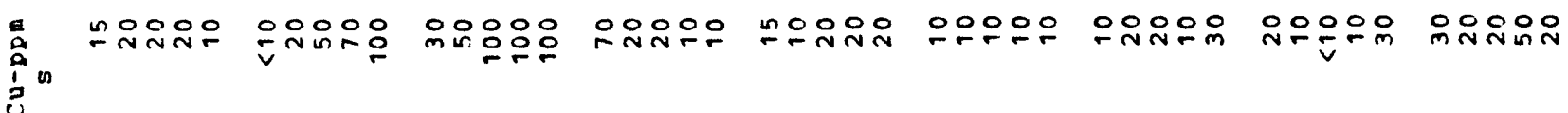

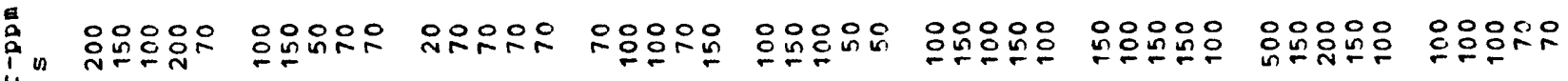
u

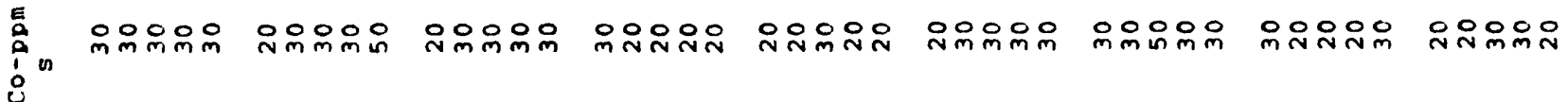

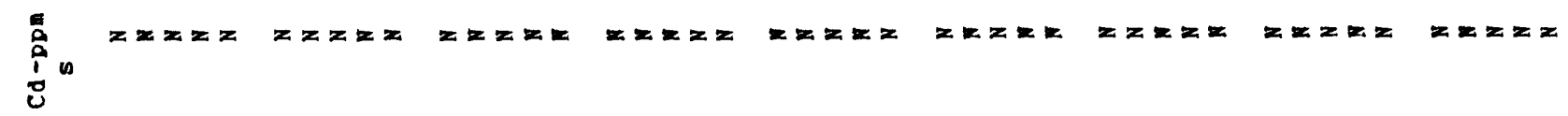

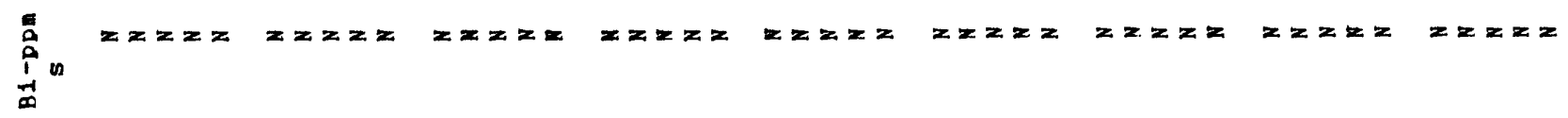
do

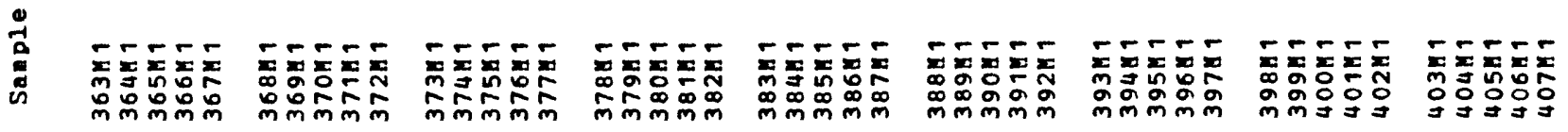




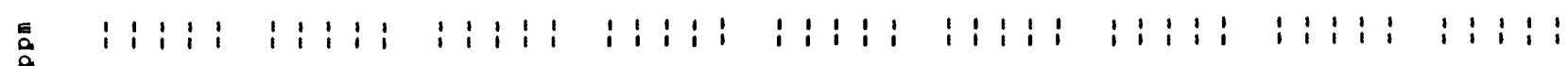

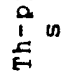

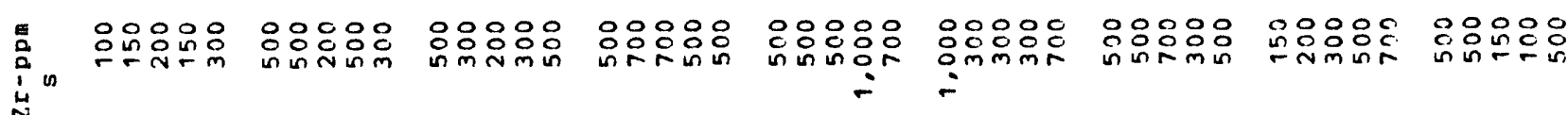

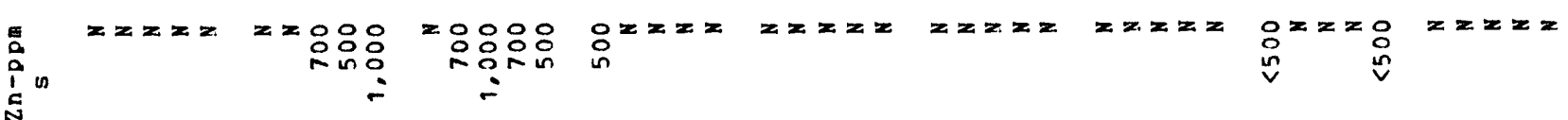

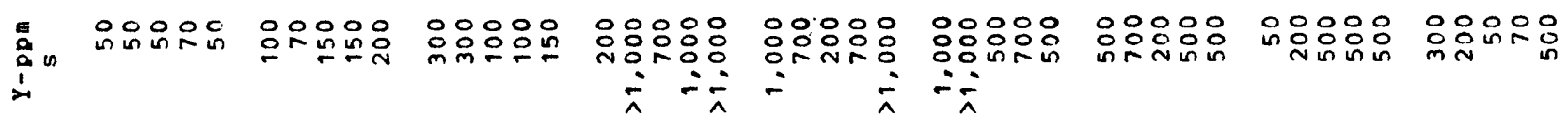

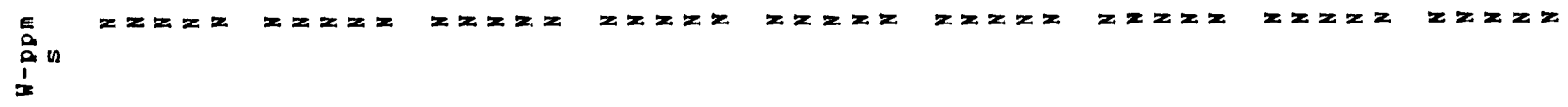

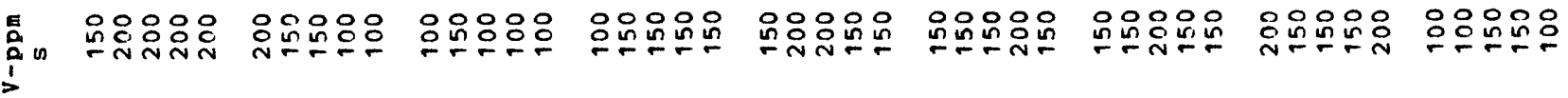

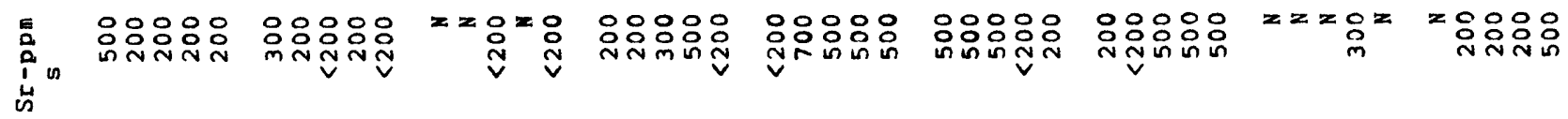

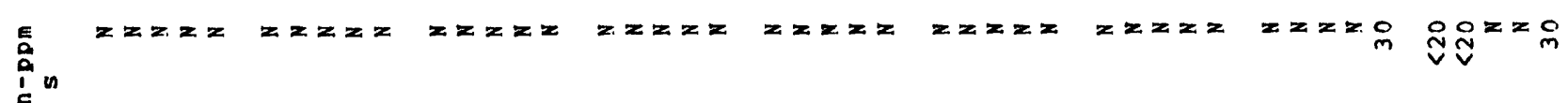

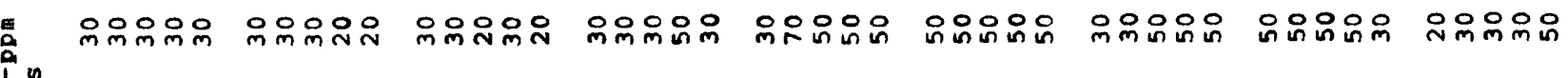
is

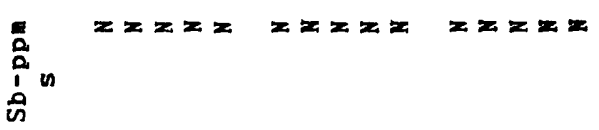<smiles>C=C=C=C=C=C=C=C</smiles> 


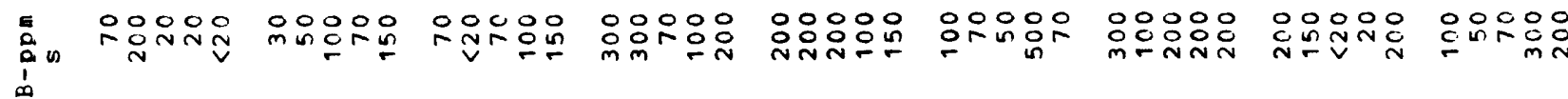

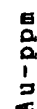

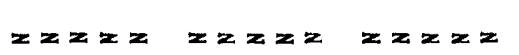

$\underset{x}{\ln }$ us

$z=2 z$

$x=2 x$

$z z 2 z$

$z=z z$

$z 2 x z=$

$z x z=$

$z z z z$

$z z z z$

$z z z z z$

is n

点

$z z z z z \quad z z z z$

$z=2 x=$

$x=2 x=$

$z x z z$

z. $z=2$

$z z z z$

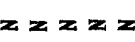

$z=2 x=$

壁次

응웅ㅇㅇㅇㅇㅇㅇㅇㅇㅇㅇㅇㅇ응

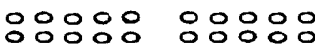

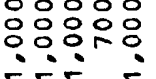

응ㅇㅇㅇㅇㅇㅇㅇㅇㅇㅇㅇㅇㅇㅇㅇㅇㅇㅇㅇㅇㅇ

응ㅇㅇㅇㅇㅇㅇㅇㅇㅇㅇ

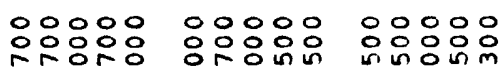

$\because \because \because 2$

$\therefore$ :

$\therefore$

$-$

$\underbrace{0}_{0}$

onomo

กับำ?

:‥?ำ:ㄴ?

ㅇํㅇำ แn ?ำ?

ㅇำ $\frac{0}{0}$

กำ. ำ

․․ำ no nun $-1$

范化

응웅ㅇㅇㅇㅇㅇㅇㅇㅇㅇㅇㅇㅇ

응요응

으웅웅으

은옹ํㅇㅇㅗ min.

…

m...

웁유운음

웅ํํㅇํㄴ

ํํํํํำำำำ ㄴ.

0
0
0
1
0
0

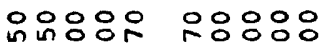

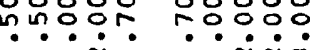

응요융유

웅ㅇㅇㅇㅇㅇ

웅우웅ㅇ

운유욲오

응웅ㅇㅇ

웅워능ㅇ

ㅇํㅇํํํํํำ

莕n

0000000000 $\dot{n} \dot{\circ} \dot{n}$

ก.?

…‥

0000000000

$000 \% 0$

$0: 00: 0$

00000

00000 nríg rígó

드웅은

우는응은

ninir

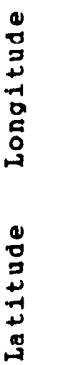

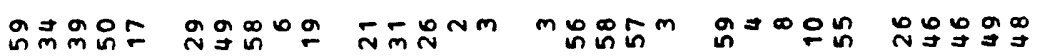

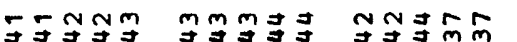

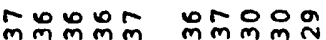

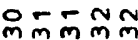

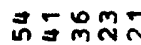

$\stackrel{\sim}{\sim} \stackrel{m}{\rightarrow}$ 운

$\cong \infty$ on in

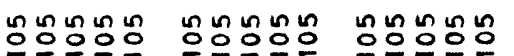

nํํㅇํㅇํㅇํㅇ

แn n⿺n一

กำกn

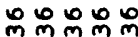

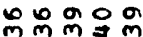

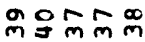

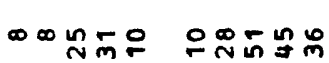

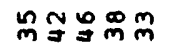

ํํㅇํㅇㅇํㅇำ

ํํㅇํํㅇํㅇํㅇ

ํํㅇํํํํํำำ

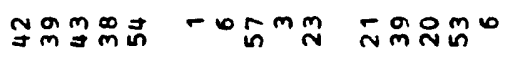

NNNNM mmoON

Nmmun

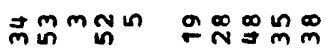

กีกับ ํㅗำ

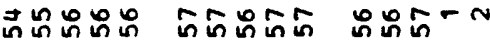

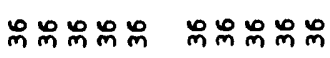

预诵品品

mmagu nnONO

onoor

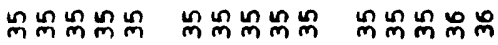

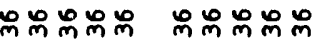

ํํำํำ

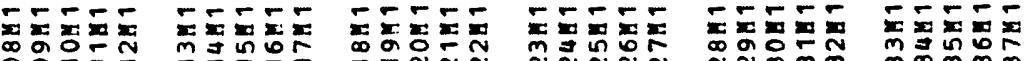




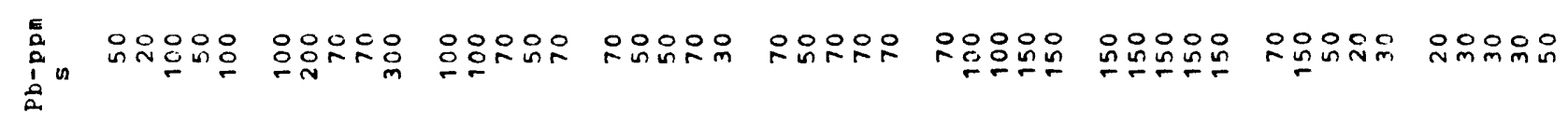

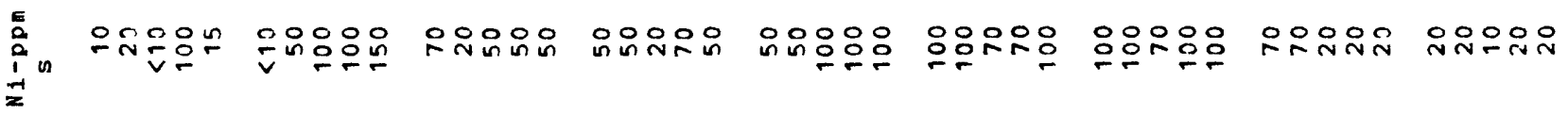

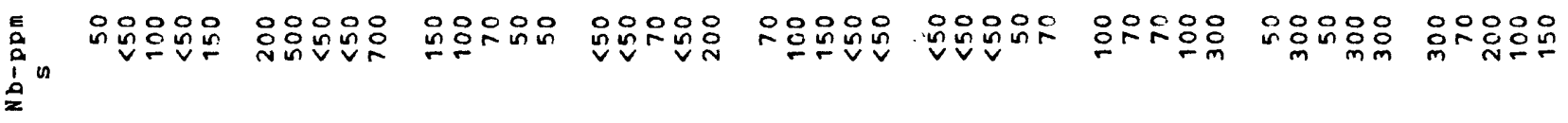

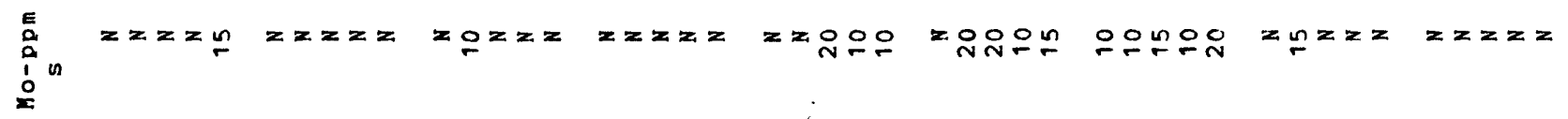

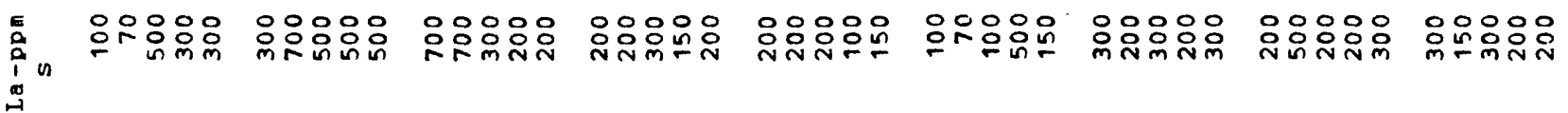

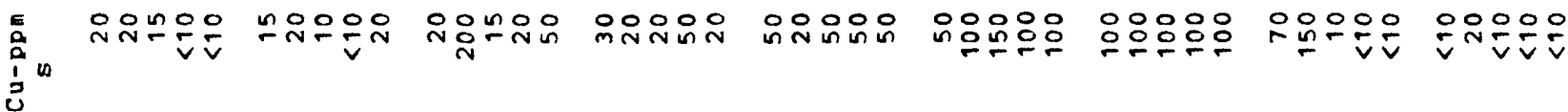
3

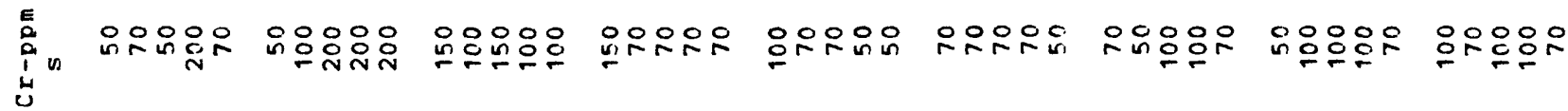

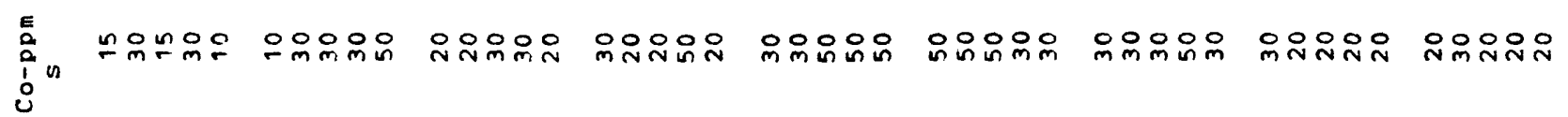

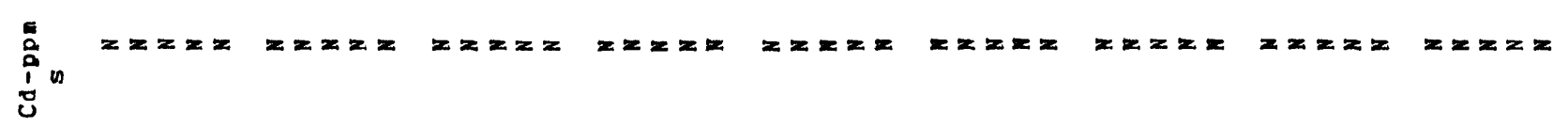

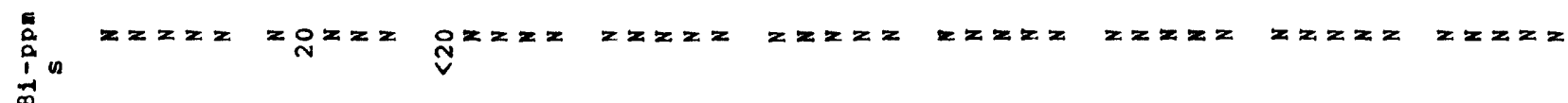
要

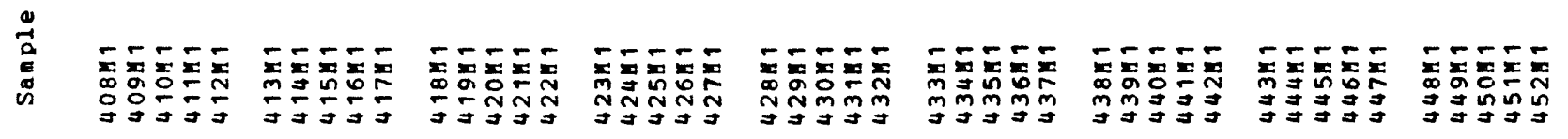




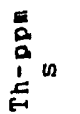

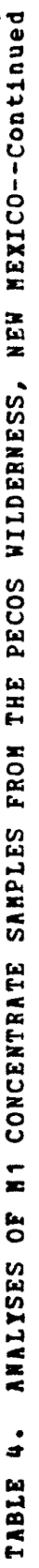

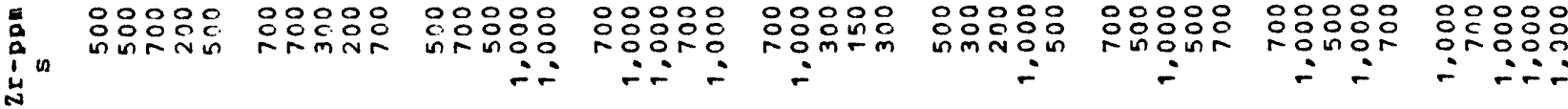

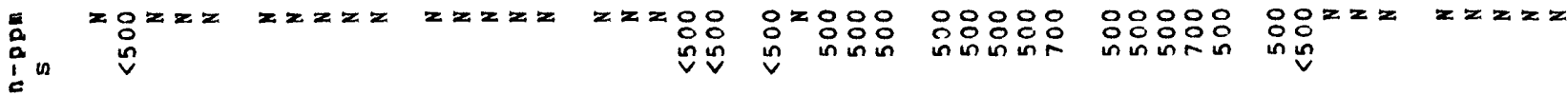

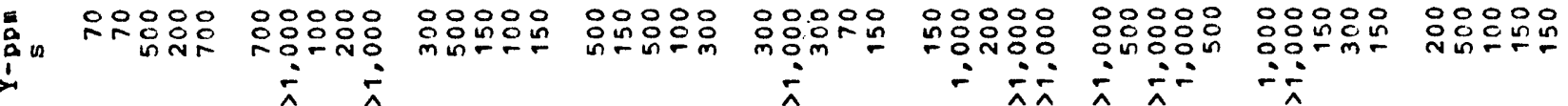

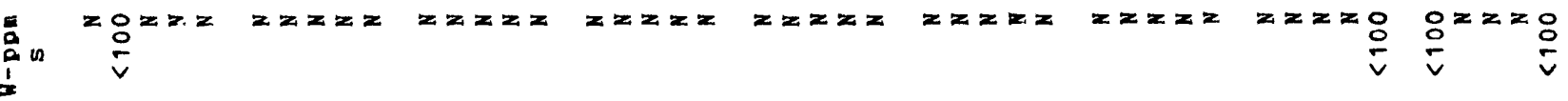

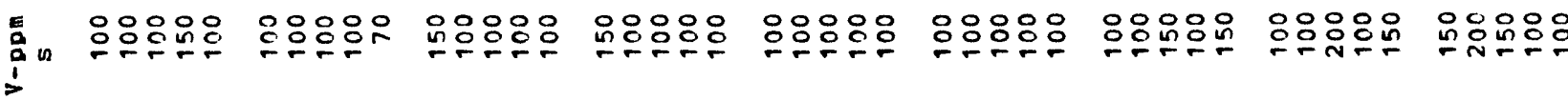

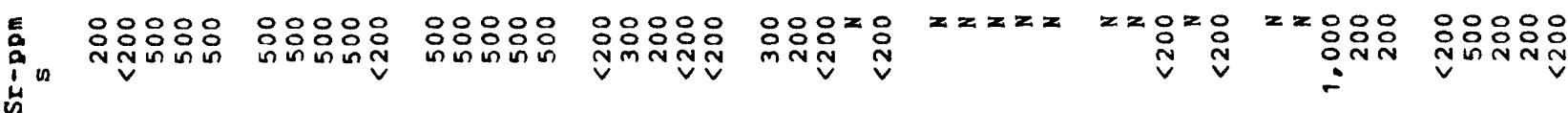

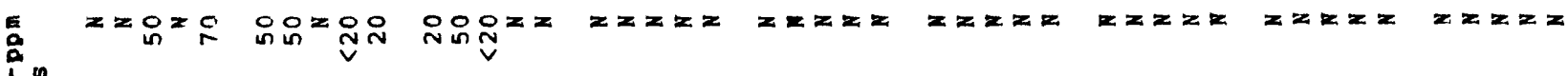
in

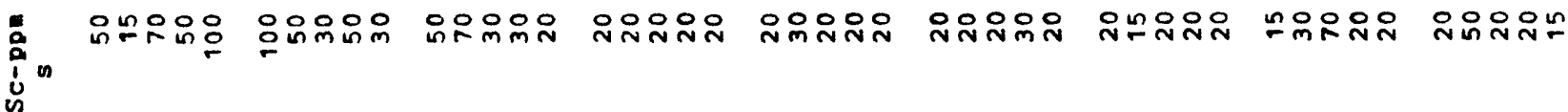

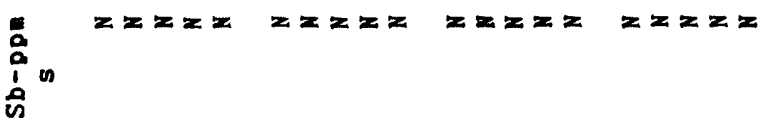<smiles>C#CC#CC#C</smiles>

$x \geq z=2$

$z=z a z$ $z=z z=$ $z z \geq z=$

\section{$\underset{\text { a }}{\stackrel{2}{a}}$}

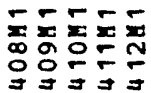

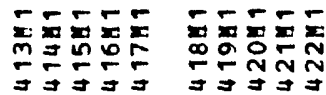

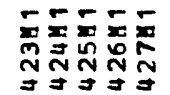

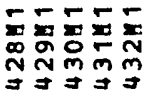

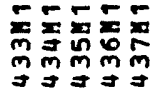

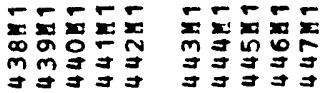

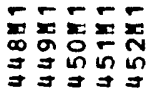




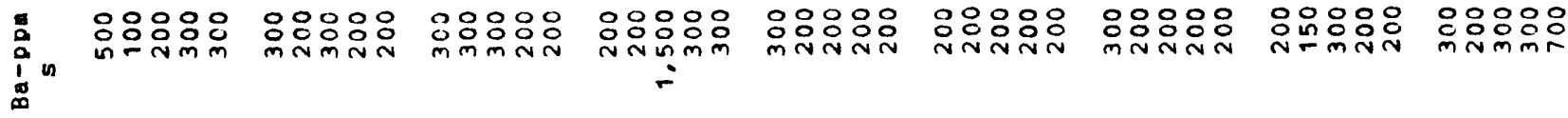

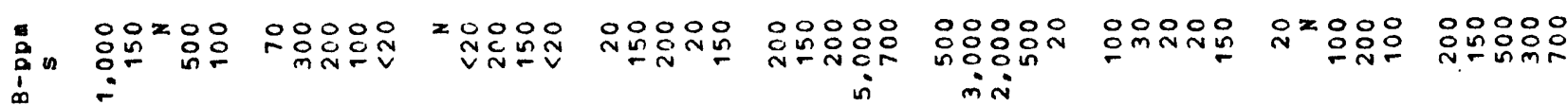

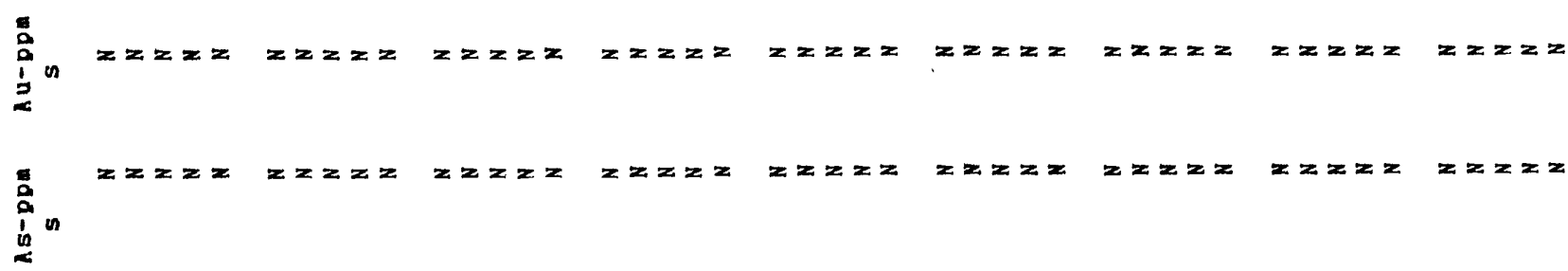
否

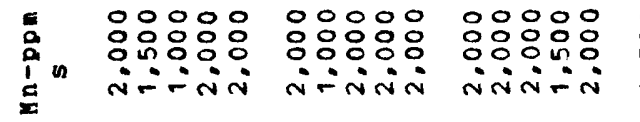

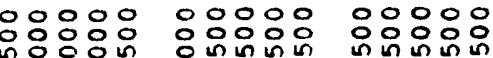

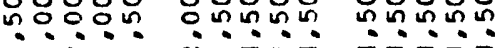

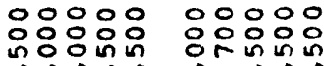

00000 inis

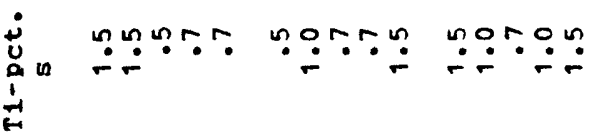

$0.0 \% 0$.

00 n

$0.0 \% ?$

nNo00

no000

o onn

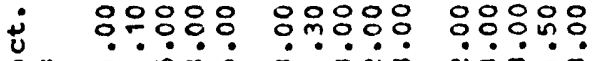

응응용ㅇㅇ 응응응

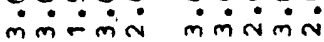

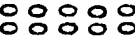
imimin

용으

ㅁำ.

98090

응ㅇㅇ웅 i

inm

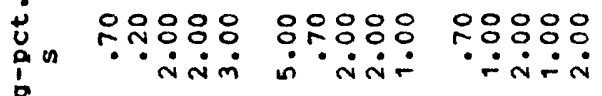

응응응응

용ㅇㅇㅇㅇㅇ

응ㅇㅇㅇㅇㅛ

लंñ -

mंmंñ

iंi⿻im

응응용으

응유융ㅇㅇㅇ

응ㅇㅇㅇㅇㅛ

䓪

$0: 000$

0 n. 000

00000 응아요

n rra

rㅜㅇㅛ

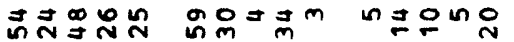

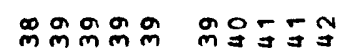

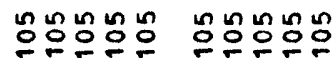

ปฐฐ

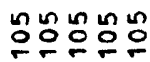

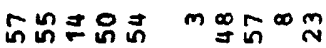

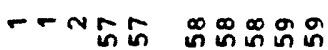

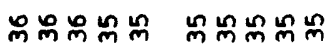

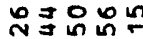

으용ํㅇ

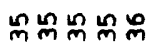

กำำก yma กำn 응응ㅇㅇㅇㅇ은

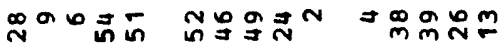

or 琞命

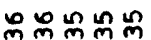

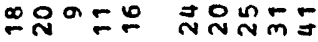
寻寻寻寻

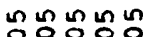

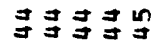
응ㅇㅇ응응으

寻寻寻寻

m䑻吕

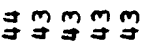

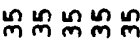

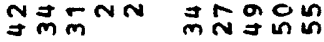
ยュュココ 능융ㅇㅇ유융

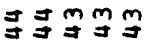
nn以n 으응ㅇㅇㅇㅇㅡ

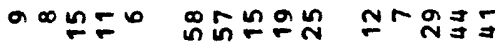

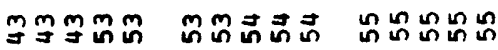

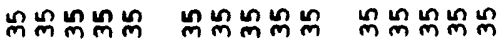




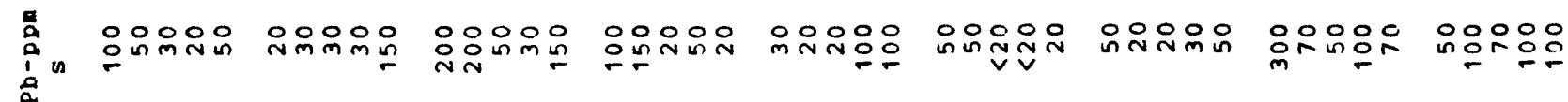

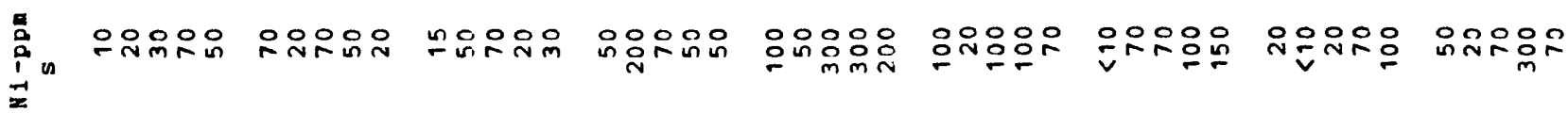

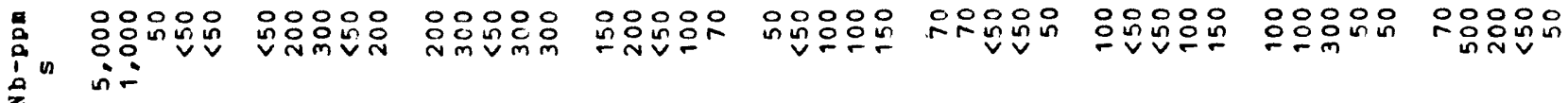

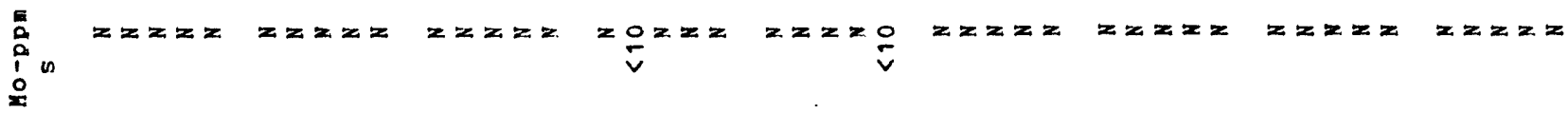

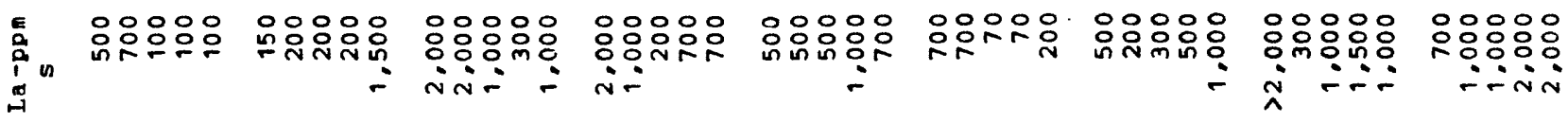

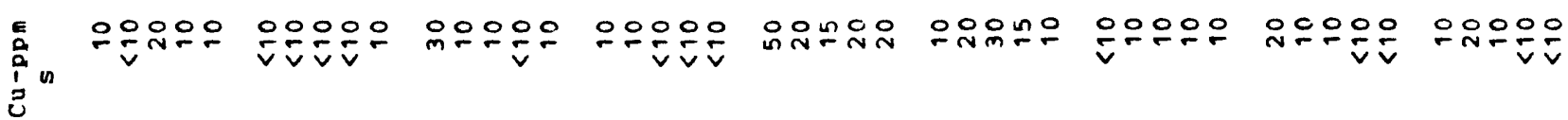

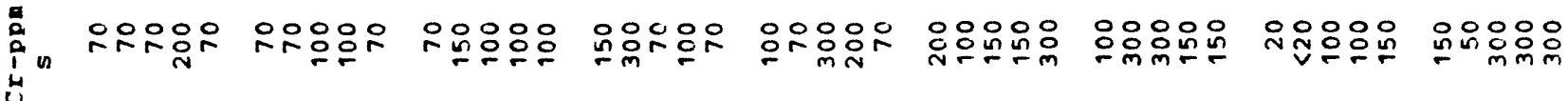

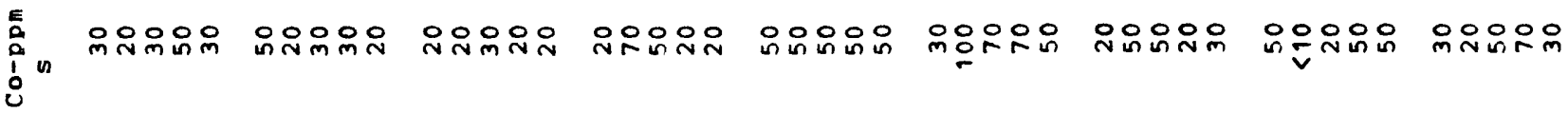

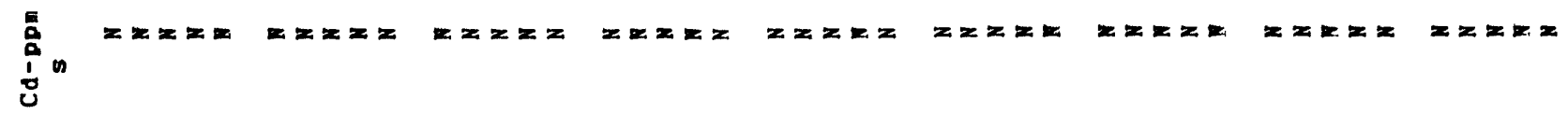

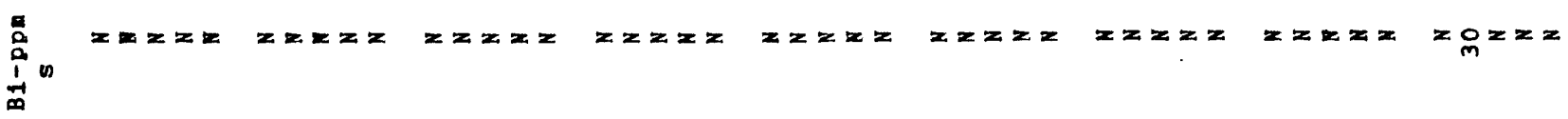
:

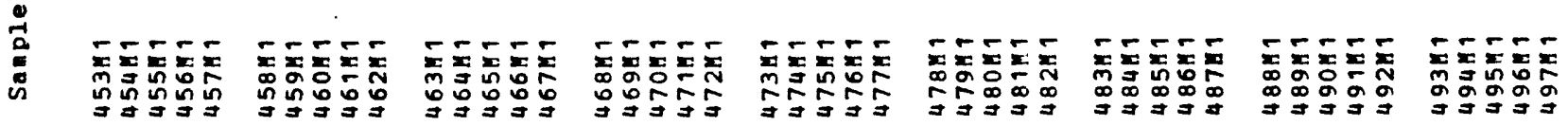




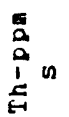

⿷

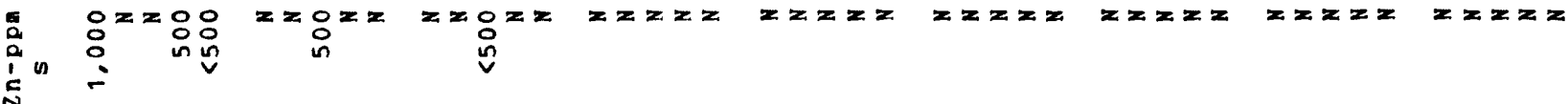

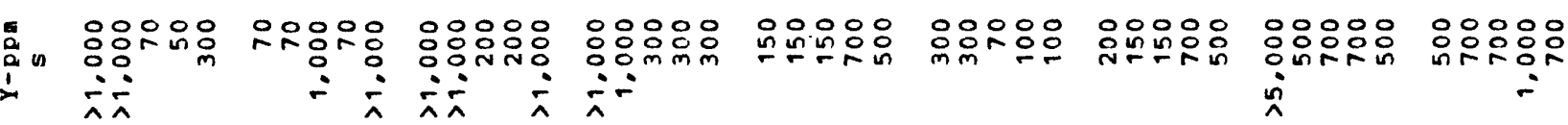

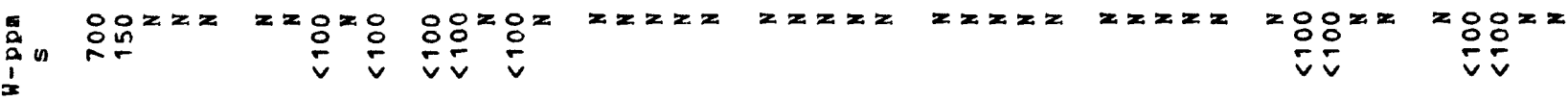

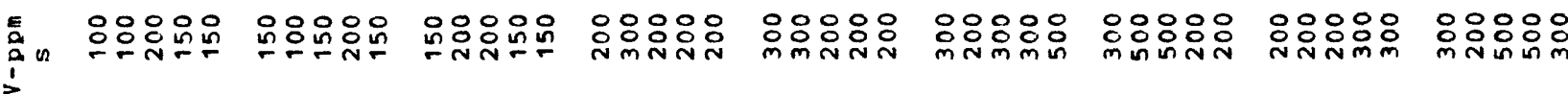

䶮

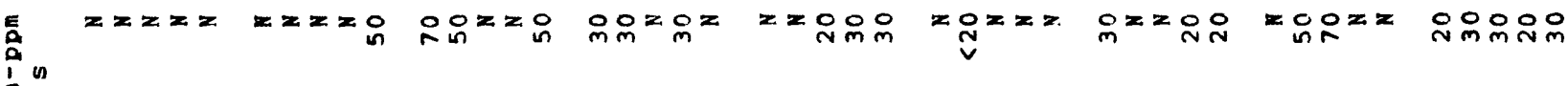

is

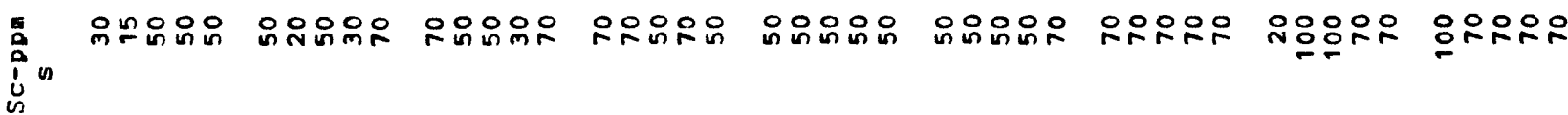

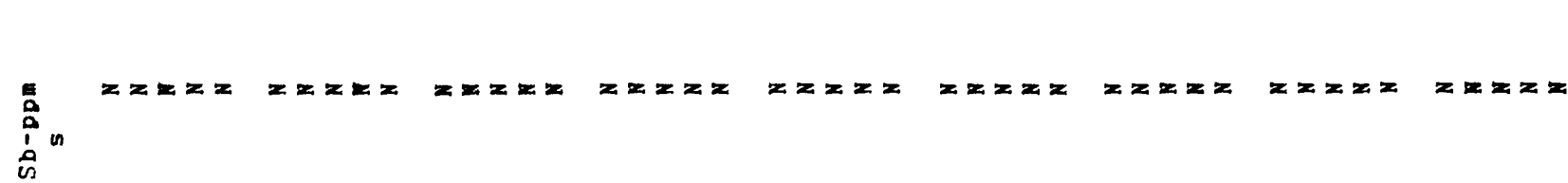

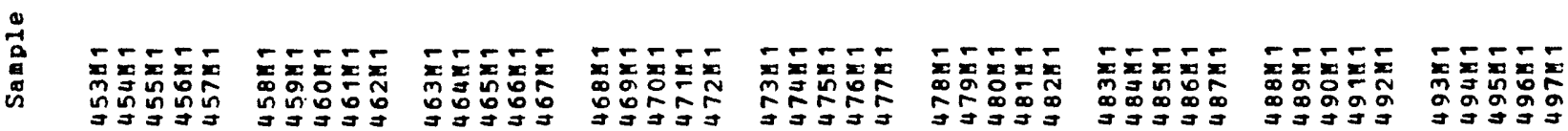




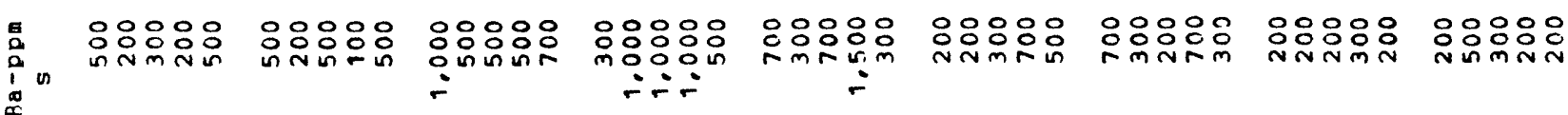

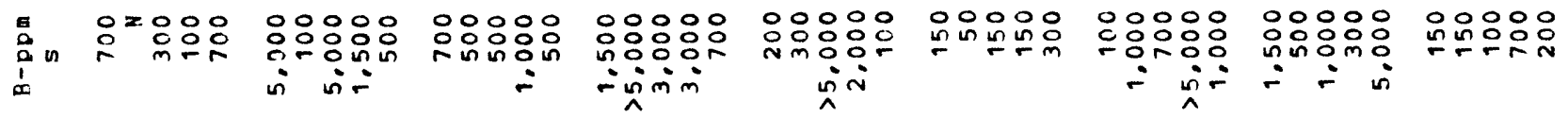

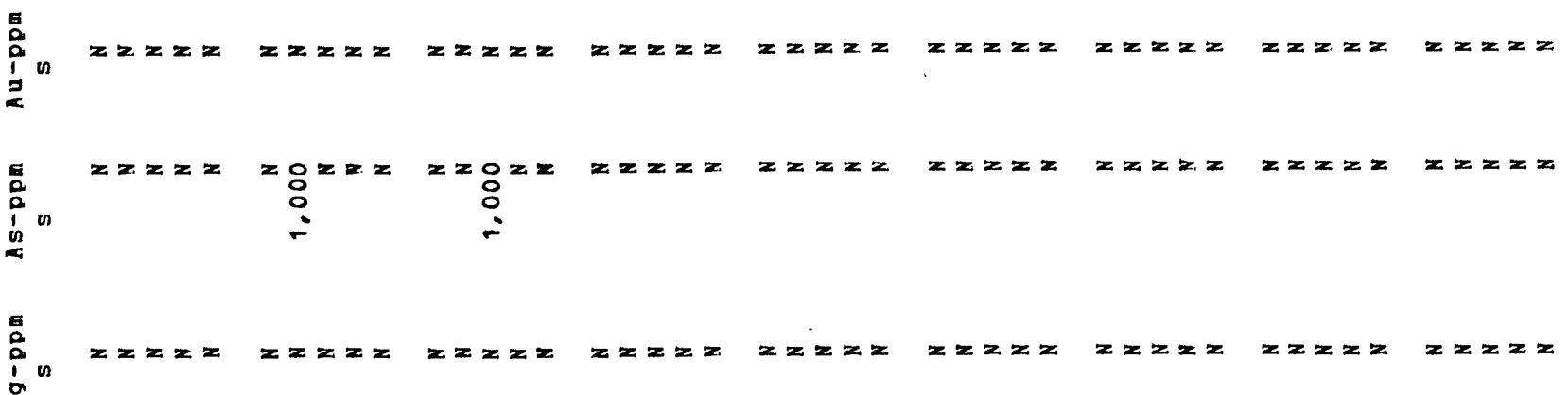

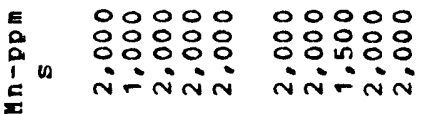

00000

응ㅇㅇㅇㅇㅇㅇㅇㅇㅇㅇㅇㅇㅇㅇㅇㅇㅇㅇㅇㅇ

nanin
808008

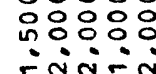

00000

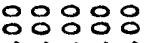
ininin
00000 응응응 inin:-

00000 응옹ㅇㅇ응응 눙

00000 응응용응 $\because \because \div$ i

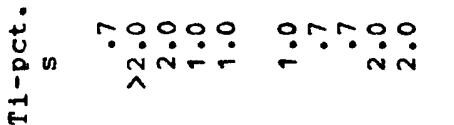

no.0ำ. no000

‥90.

ก.?.?.ำ

00 non

กำ? ?

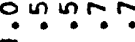

\section{응응응}

응ㅇㅇㅇㅇㅇㅇ

응ㅇㅇㅇ응

응ㅇㅇㅇㅇㅇㅇ तं $\dot{\sim} \dot{m}$

तिंm户

जinं

응웅요융

응용요

in $\dot{1} \dot{m} \dot{-m}$

응응ㅇㅇㅇ نं $\dot{n} \dot{m}$ in

응영융 जiñं

응응ㅇㅇㅇ ن்

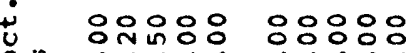

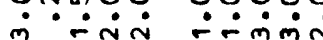

응ㅇㅇㅇㅇㅠ

ㅇㅇㅇㅇㅇㅇ응

옹잉ㅇㅇㅇ نिंن் जिं $\dot{n} \div \dot{-1}$

응ㅇㅇㅇㅇ

응웅ㅇㅇㅇ음

응융ㅇㅇㅇㅇㅠ

응ㅇㅇㅇㅇㅇㅇ

i

苔我

onooo $\dot{0} \dot{0} \dot{r}$

00000 Nmn n

जimi

$\dot{n} \div \dot{n} \dot{n}$

nंñति

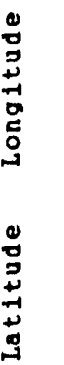

a $4-m$

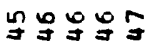

กิบับำ

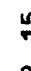

ํํㅇํํㅇํㅇํํㅇํㅇ

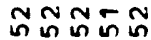

응웡요유응

キกัฒฐ

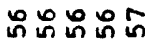

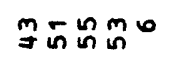

苟角踏的

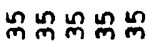

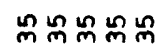

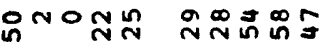

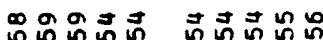

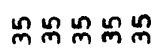

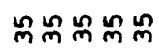

:0000 00000

00000

nin

$\stackrel{\infty}{\sim} \sim N$

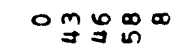

ตัฺกี่ถ

in

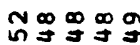

m으의

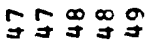

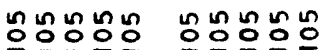

ㄴํㅇํํㅇํㅇ으응

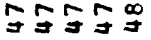

ㅇํㅇ응ํㅇㅇㅠ

テテテัญั

in

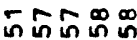

$\infty \omega-n a$

กำกำกำ

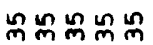

0.0000 r용ㅇㅇㅇ

00000

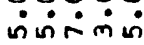

00000

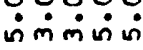

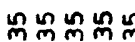

ํNำก

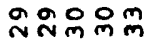

กㄴำ

으우응ㅇ응

=mñ

nana

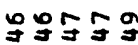

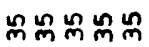

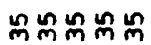

ON $\vec{N}^{m}$ m $\underset{m}{ } \mathfrak{m}$ 욜 농옹응응응

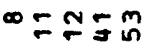
웍용요

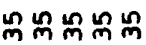

\section{离}

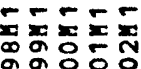

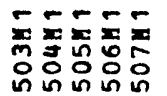
:-

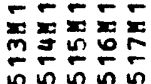

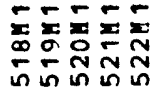

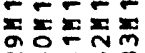
ูํำกำกำ

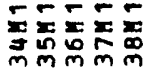

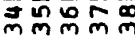

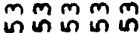

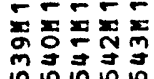




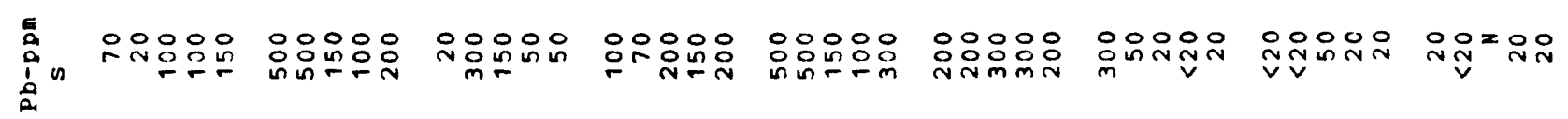

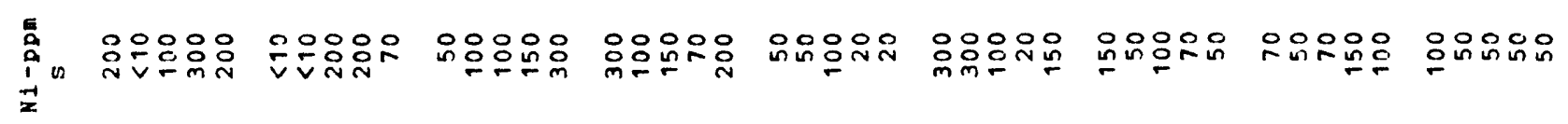

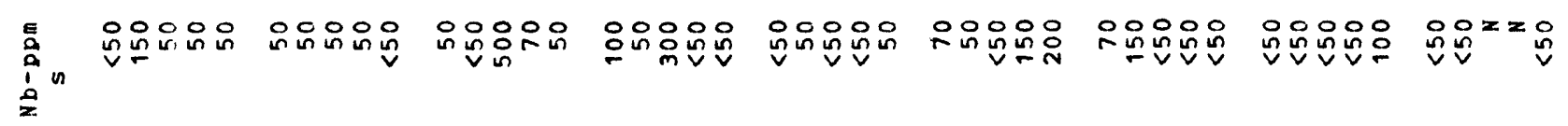

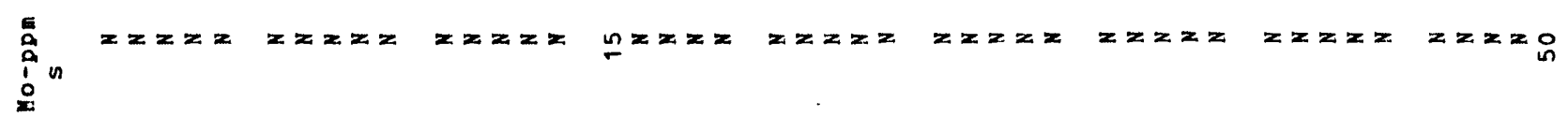

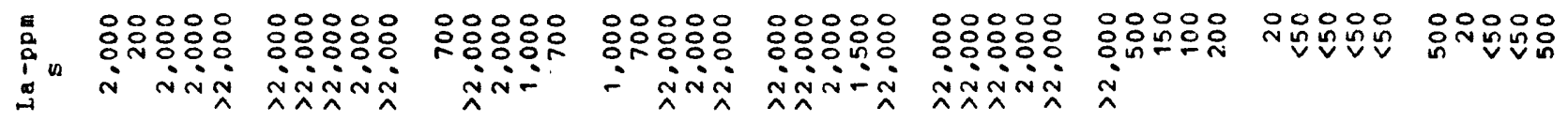

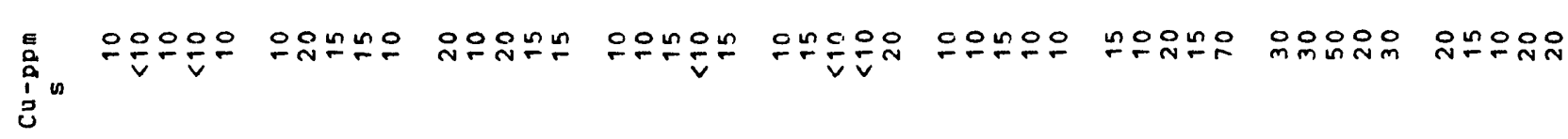

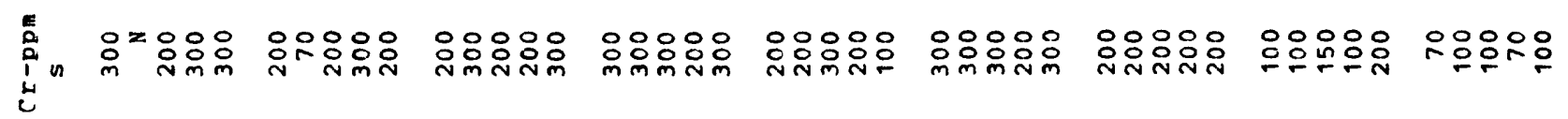

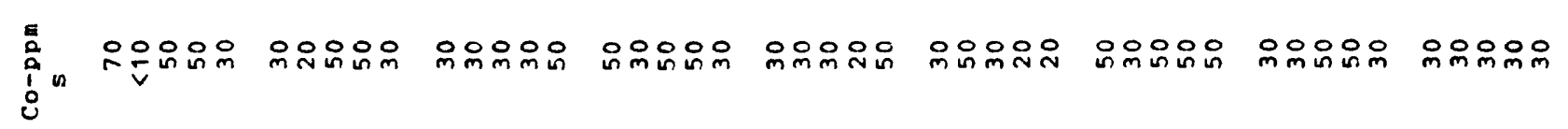

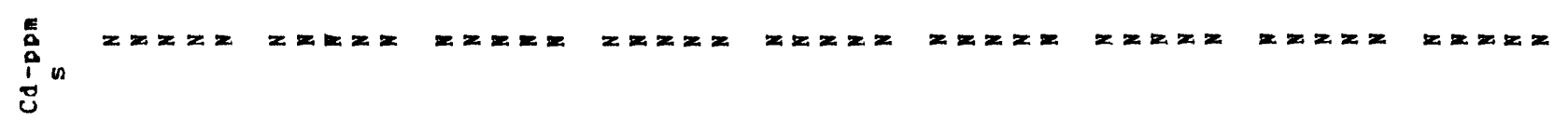

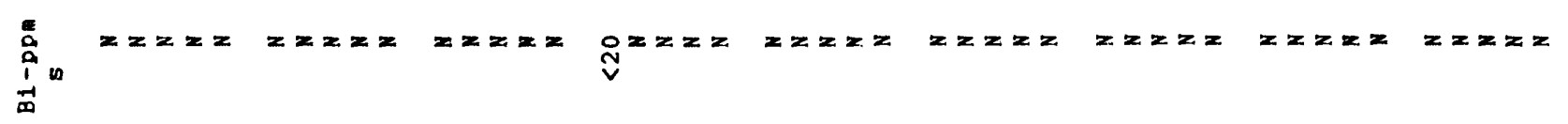

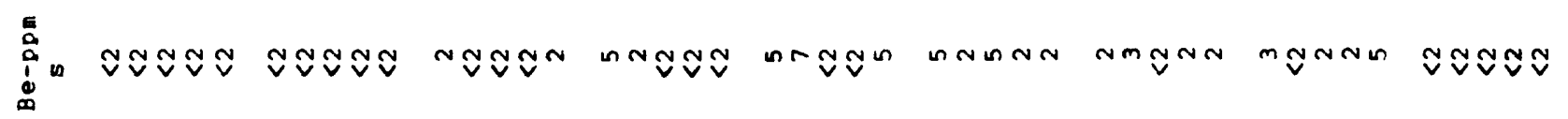

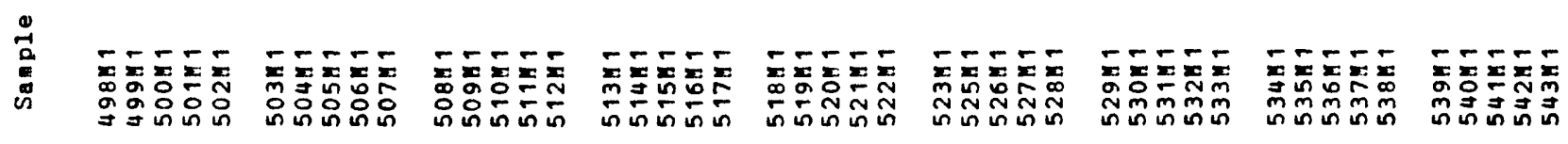


$\sum_{\substack{\infty \\ 1}}^{\infty}$

政

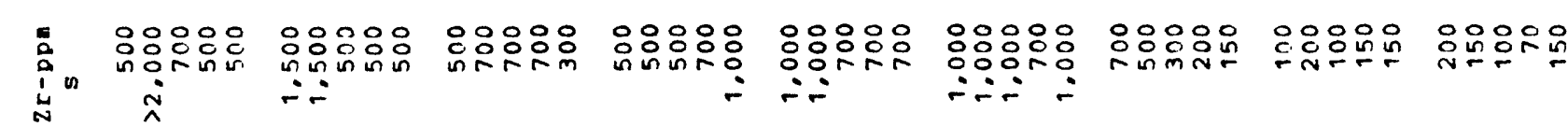

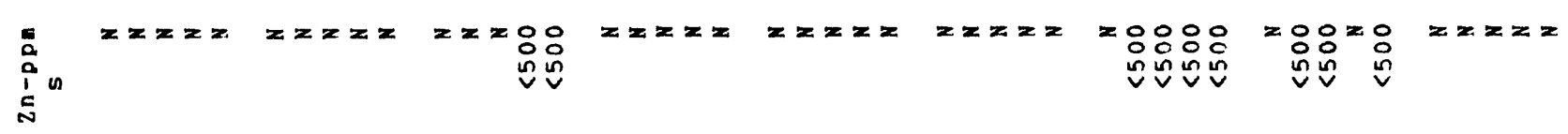

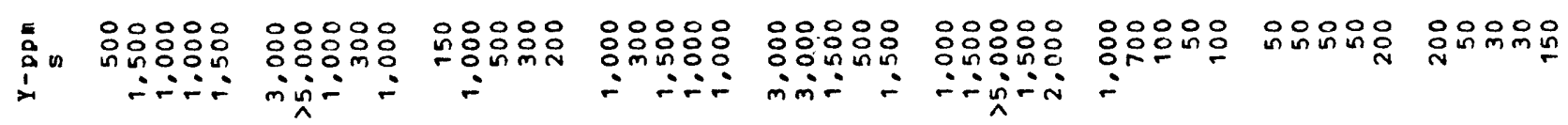

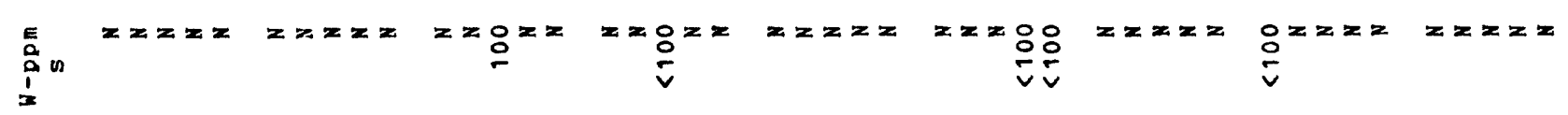

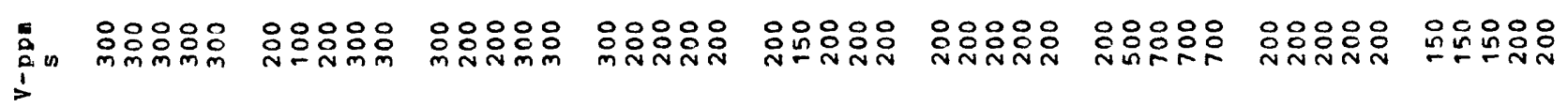

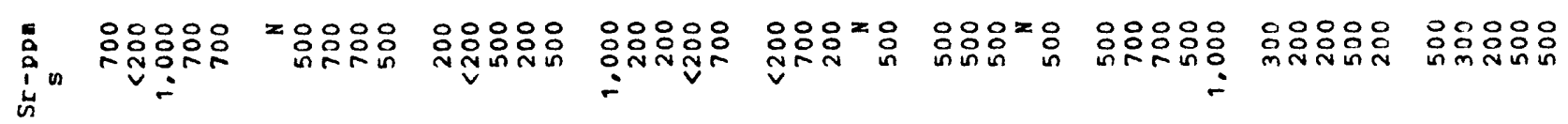

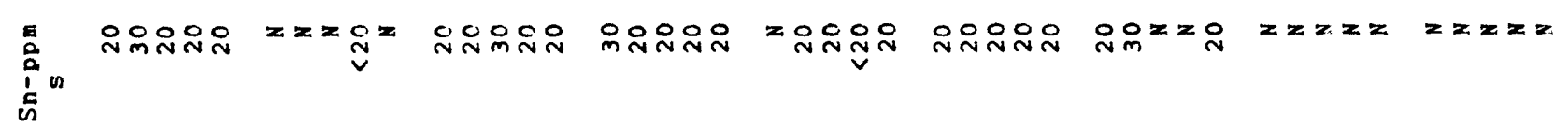

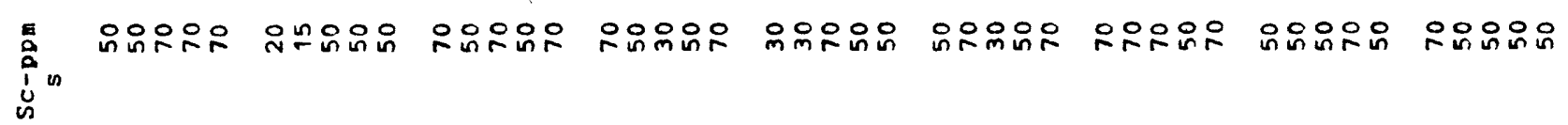

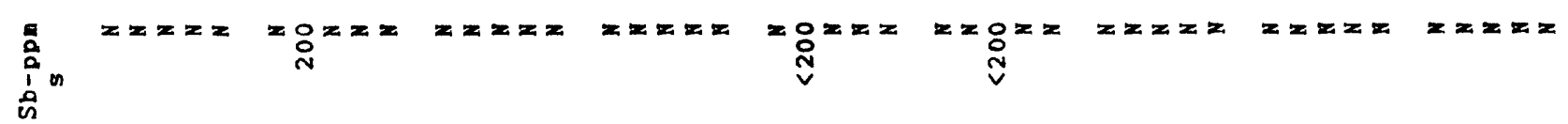

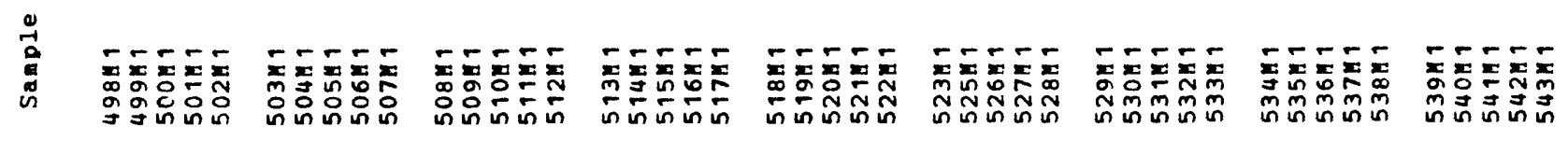




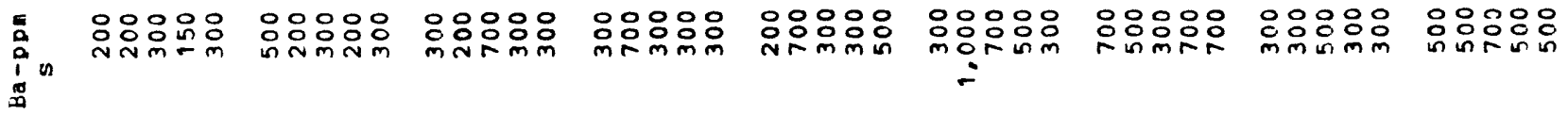

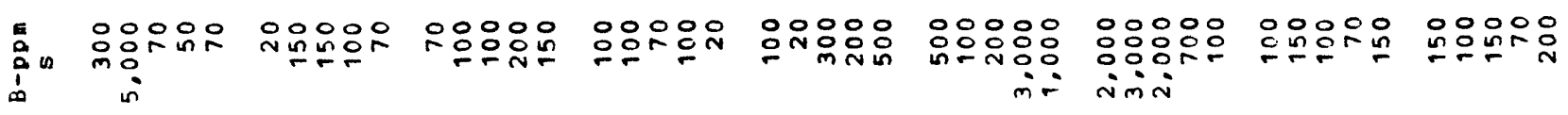

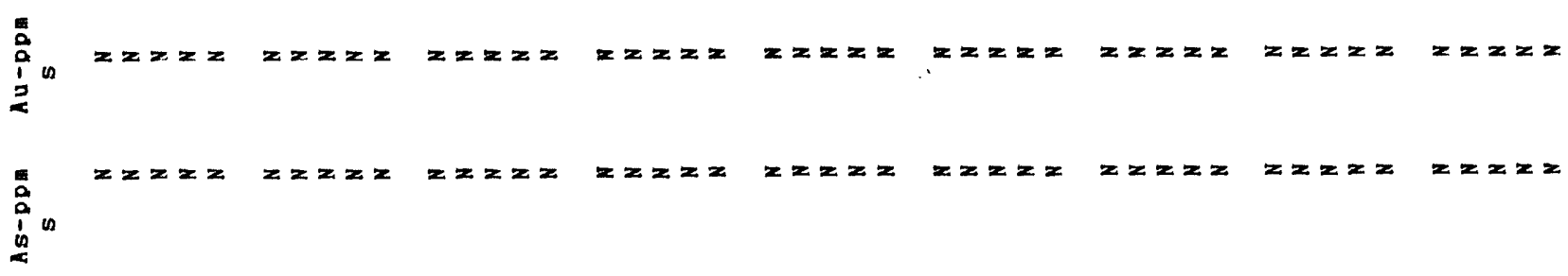

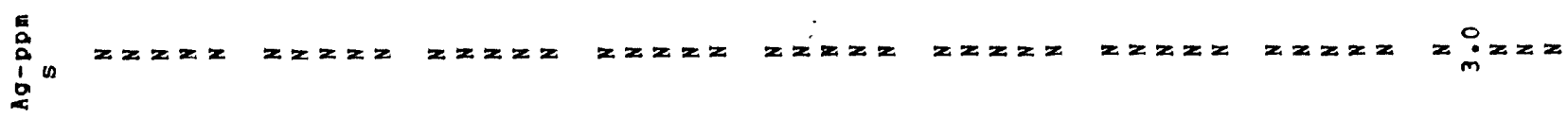

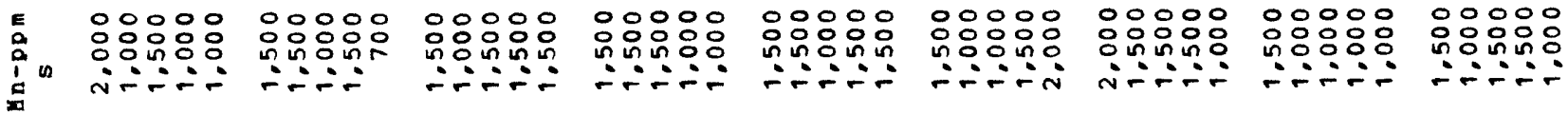

ث

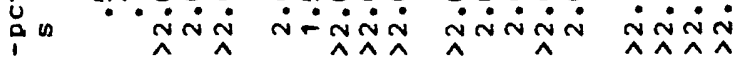
$\stackrel{-1}{\epsilon}$

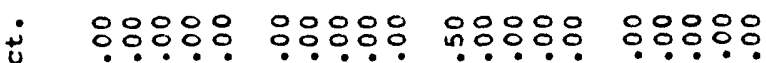

Un mirí

in mingo

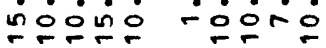
웅ㅇㅇㅇ

응응ㅇㅇ 응응응

0.00000000

00000

000 no

00000 nNNNN

iñ

iniñ

نं

inنं

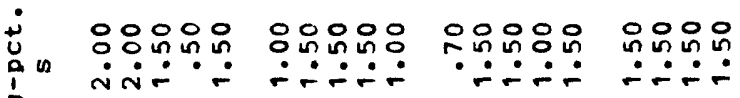
o숭 n

영영영

응영응영

옹응응 onorir noór 는ㅇㅇㅇㅇ

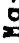

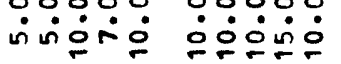

웅ㅇㅇㅇㅇ

00000

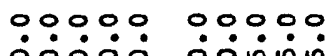

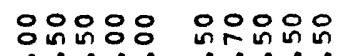

응응용요

hter

co.

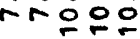

응ㅇㅇㅇㅇ 웅ํㅡ는

$0: 0.00$ 뵤ํㅇㅇ

00000

00000 는ㅇㅇㅇㅇ 우운ㅇㅇ응

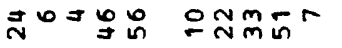

융유요

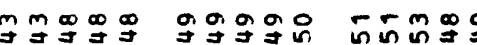

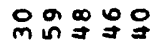

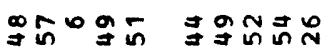

곤슨요은

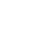

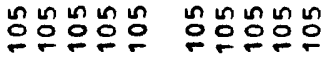

등응ㅇㅇㅇㅇㅇ 은ํำ ํำ

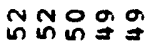
og o 00 ํํㅇํㅇㅇํㅇㅇํㅇ

농융ㅇㅇ응ㅇํㅇ 웅워웜열 ํํㅇํํㅇํㅇำ

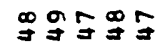
ํํㅇㅇํㅇํㅇㅇㅢ

om ํㅏ융융ㅇํㅇ

ingun

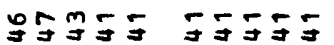

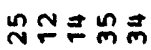
은 긍 웦도 $-F=0 N$ m nmm

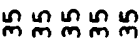

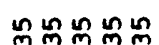

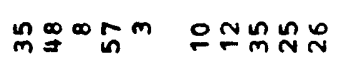

푸요 m

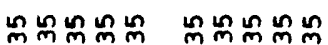

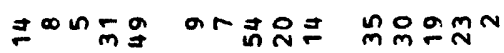

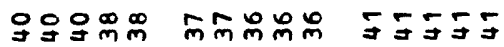

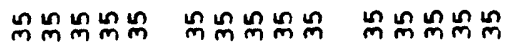

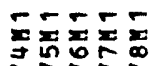
in in

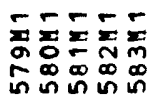

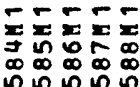

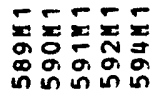

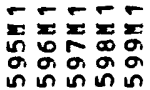




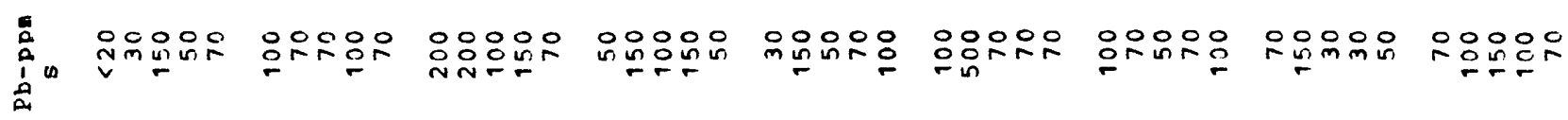

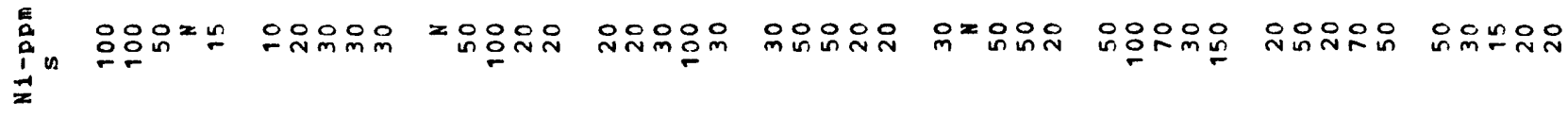
育

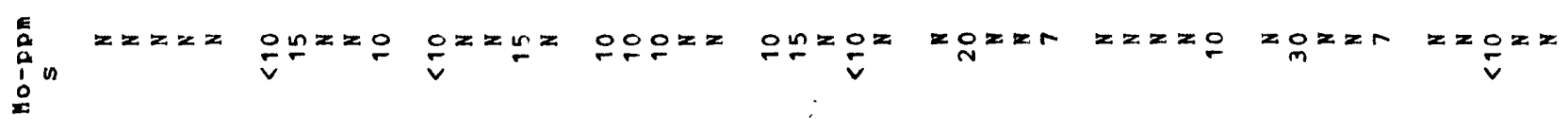
‘

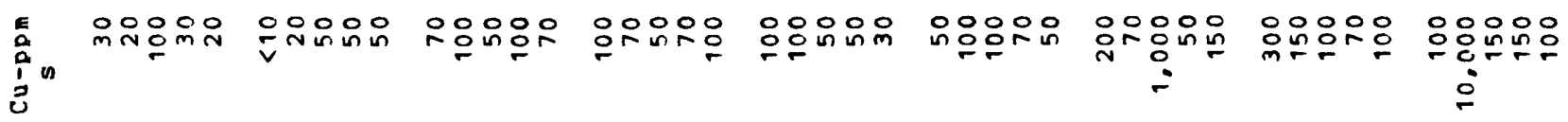

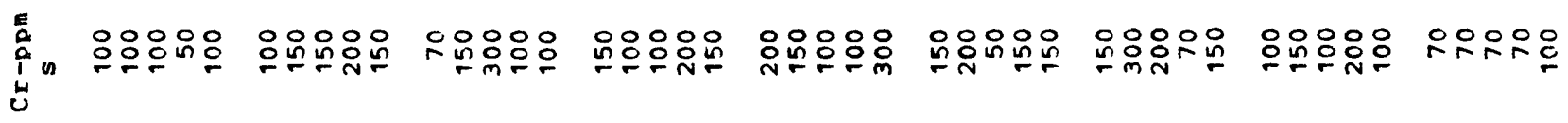

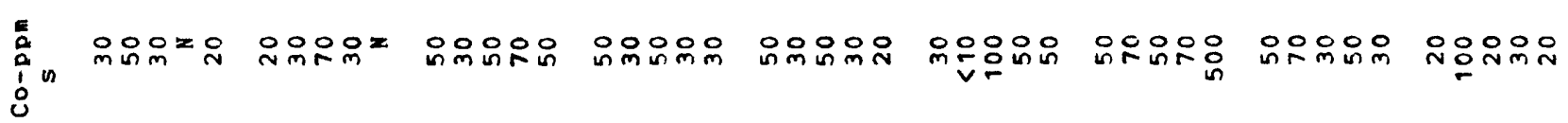

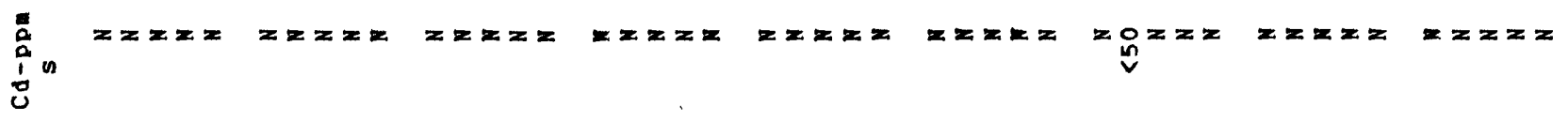

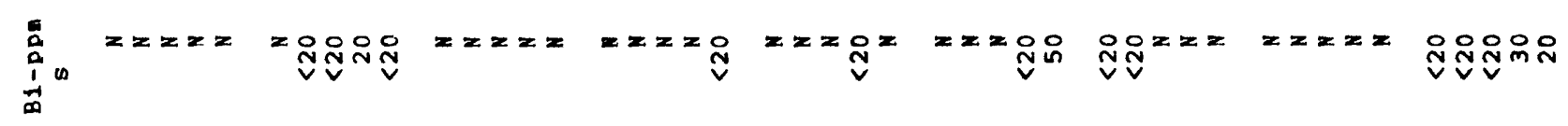

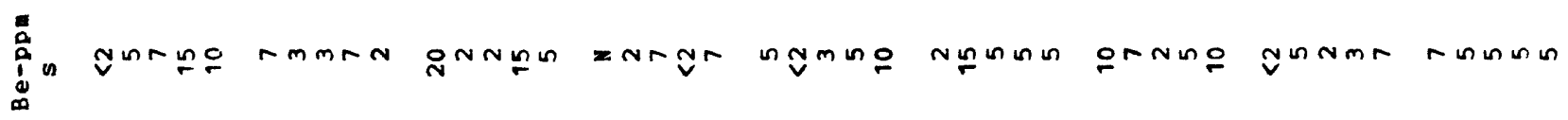

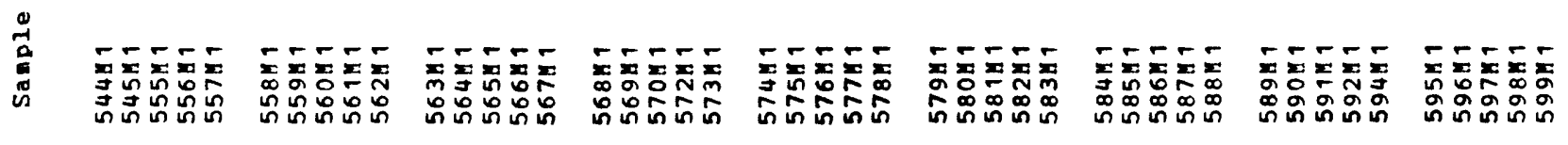




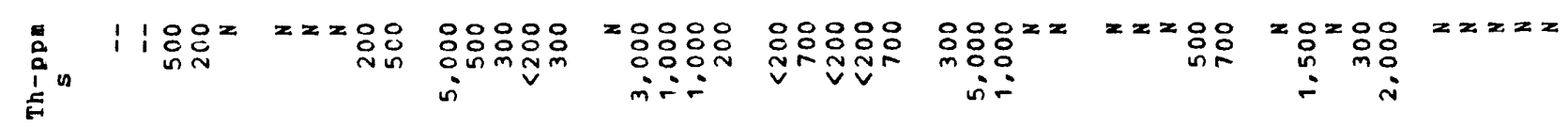

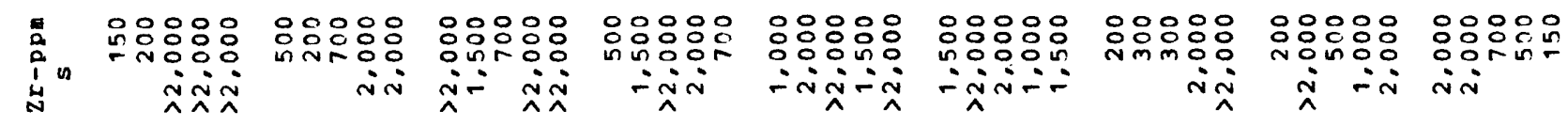

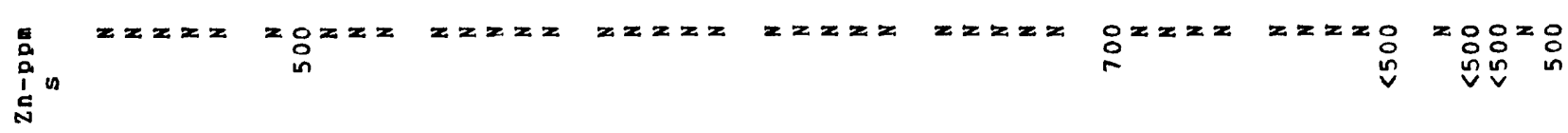

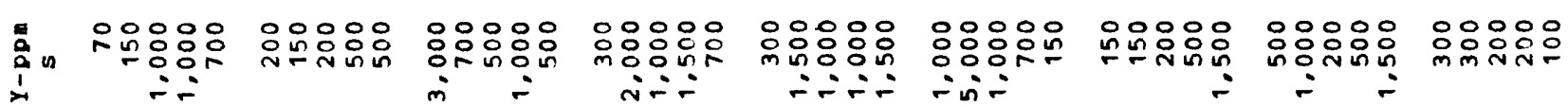

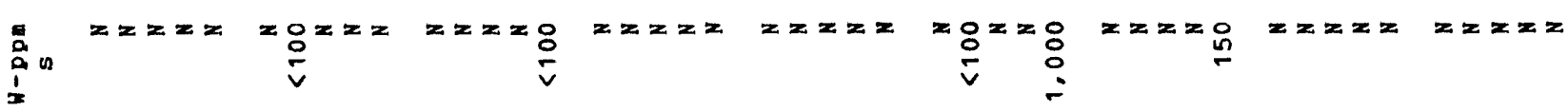

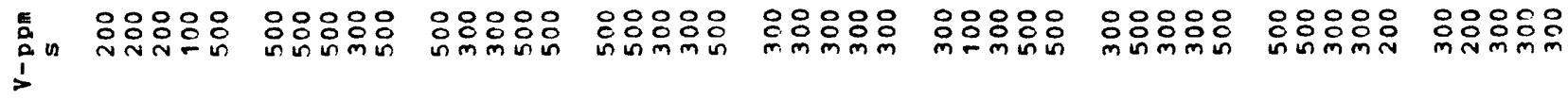

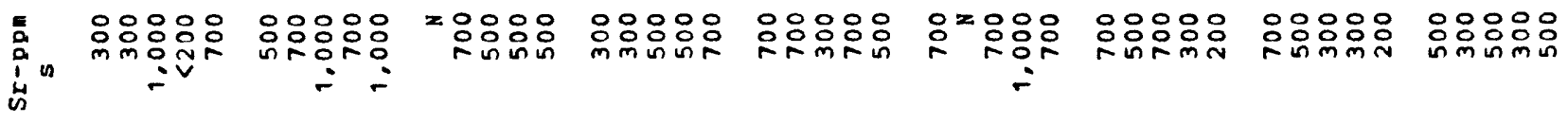

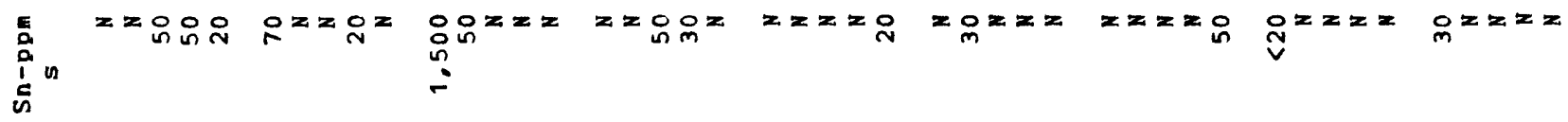

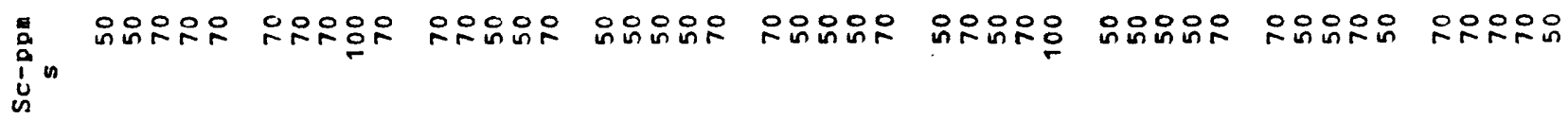

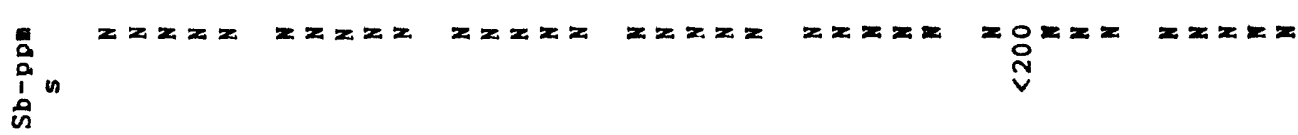

$z z z z z \quad z z z z z$

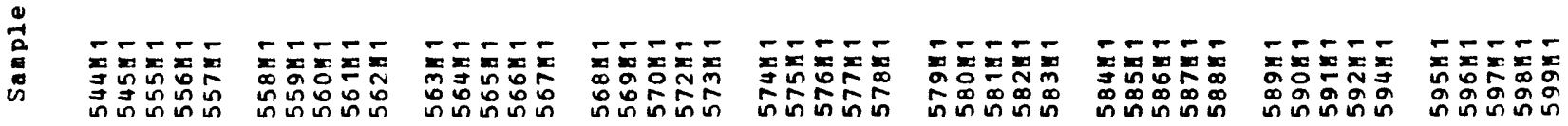




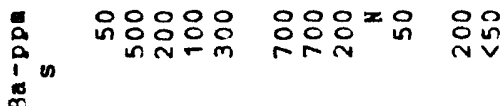

:

年

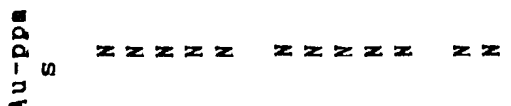

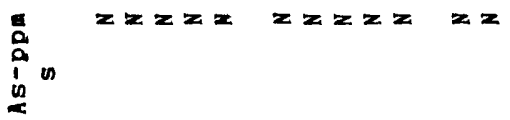

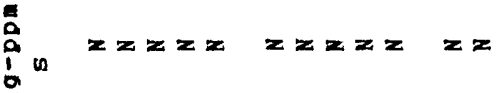

E

En minimion riónim mín

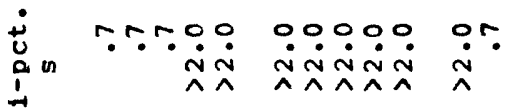

$\vec{E}$

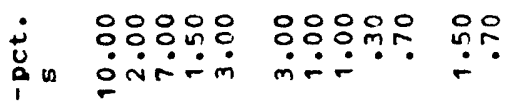

它

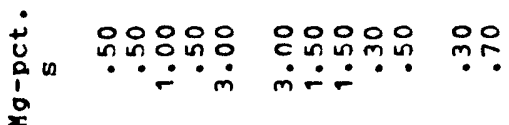

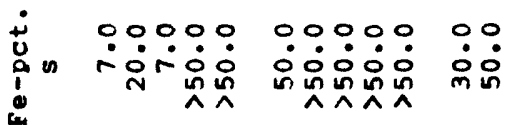

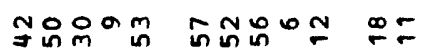

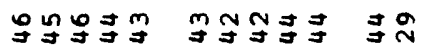

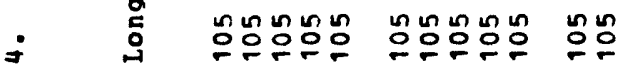

\# \&

‡

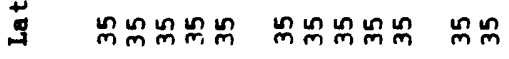

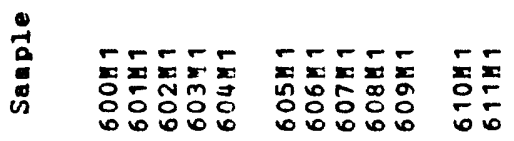




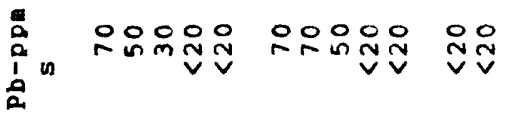

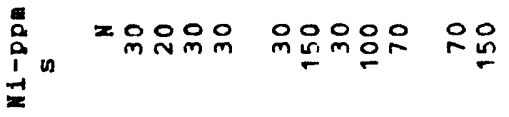

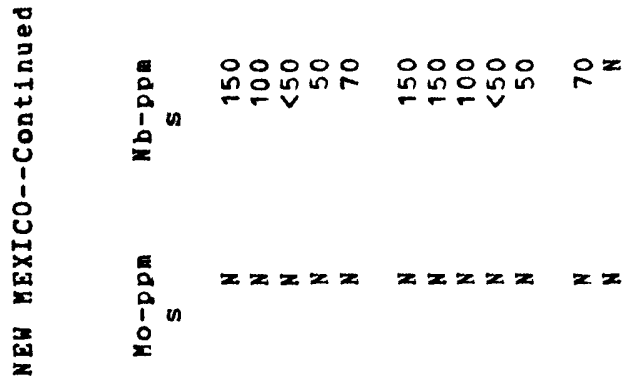

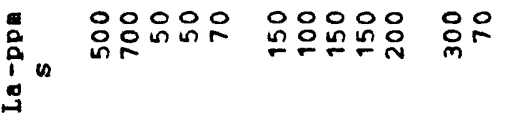

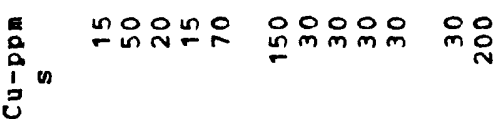

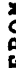

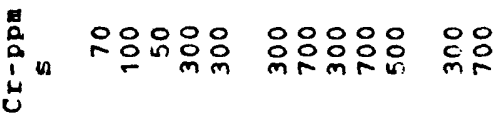

聯

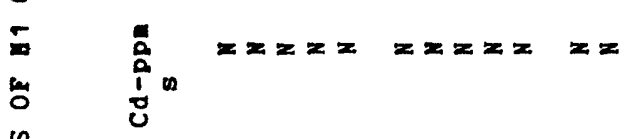

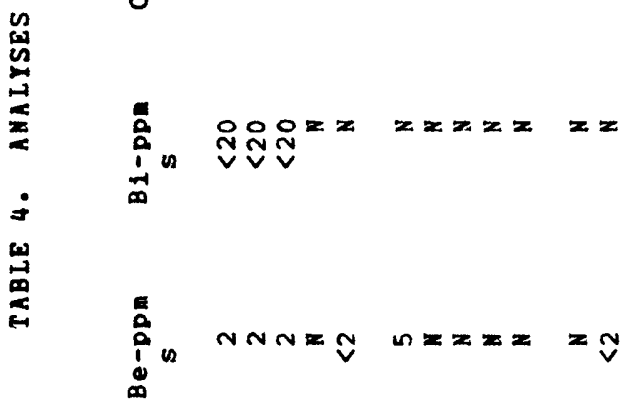

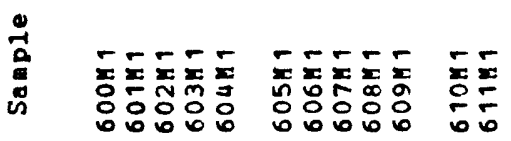




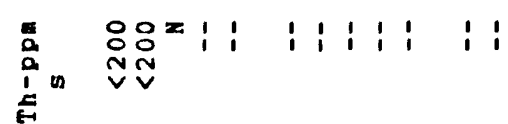

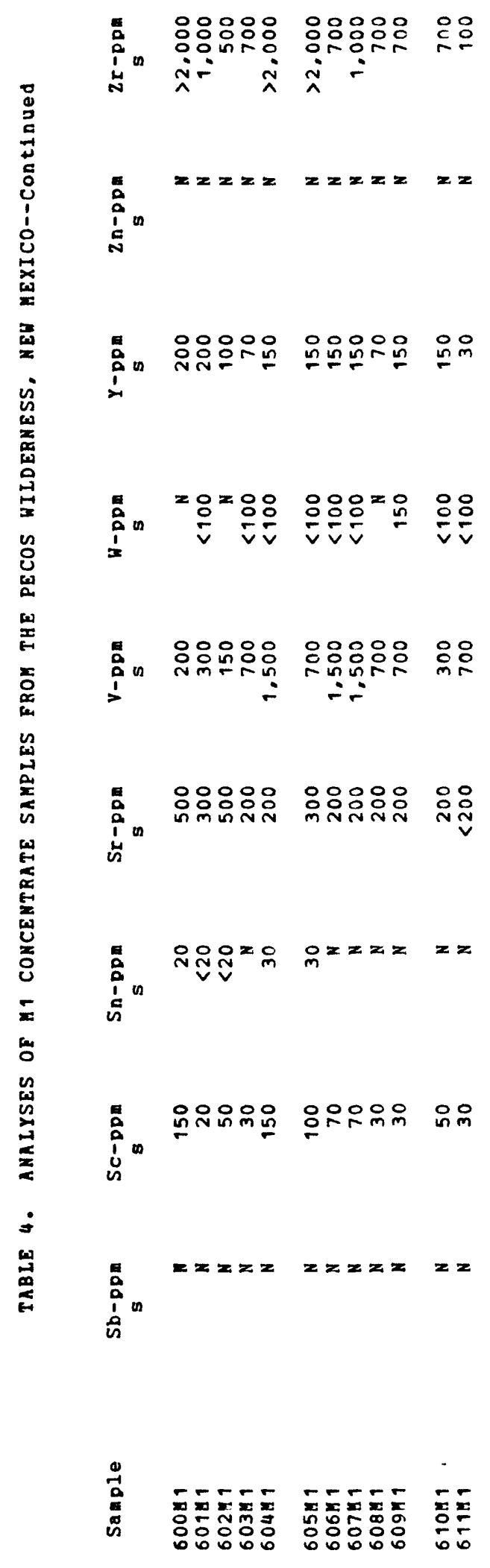




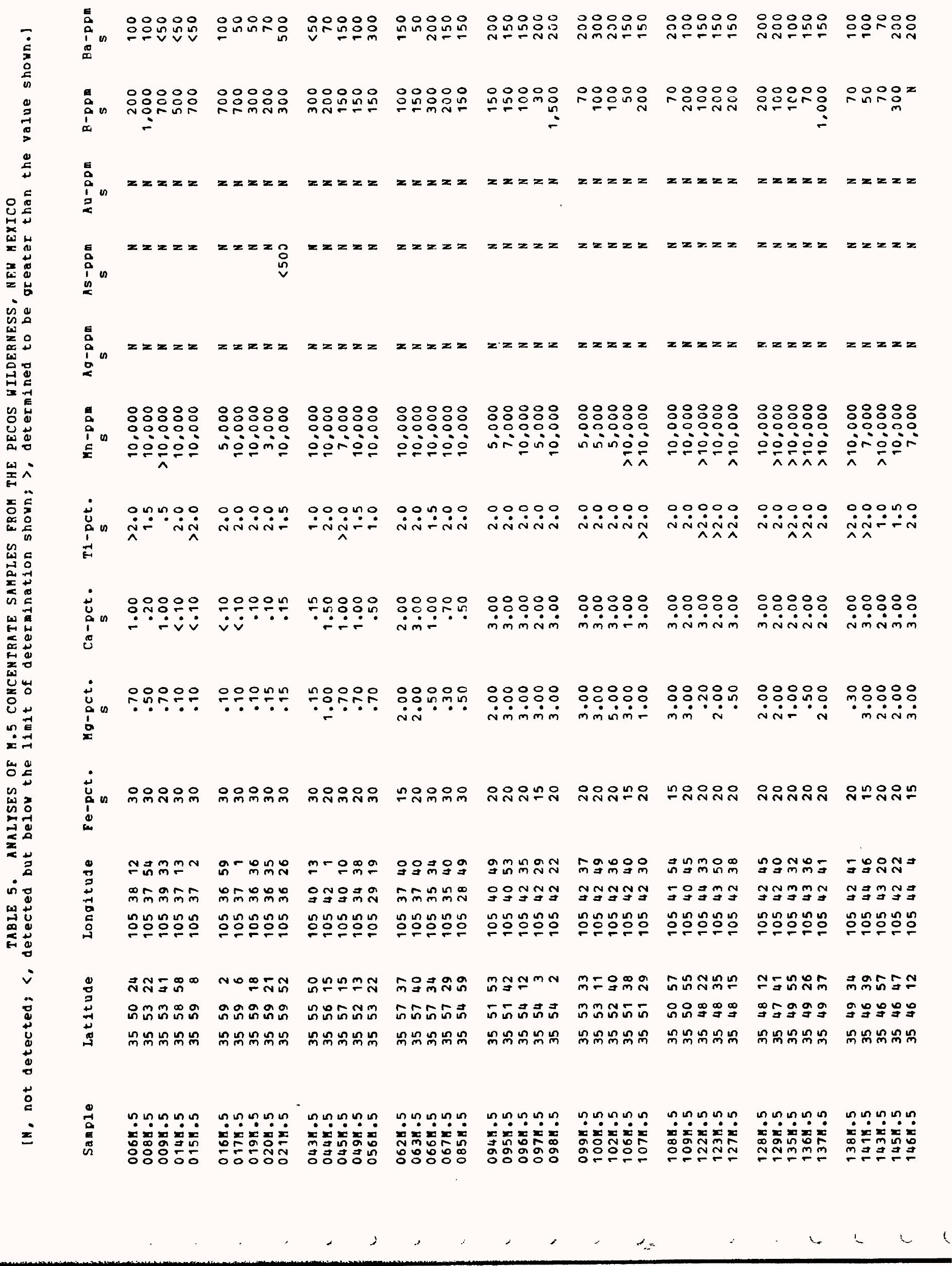




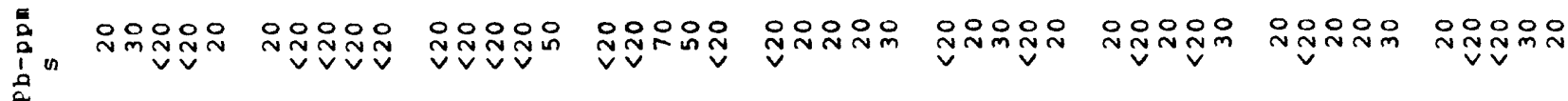

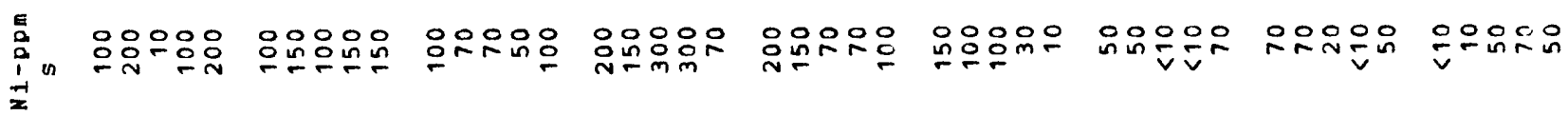

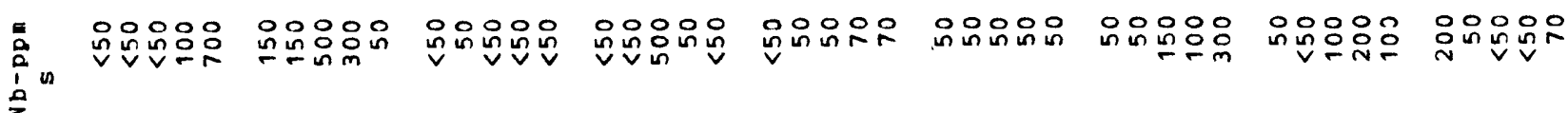

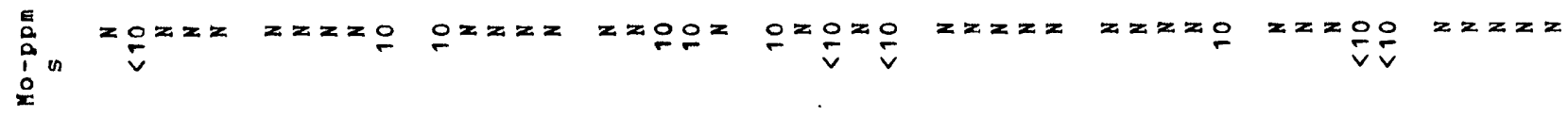

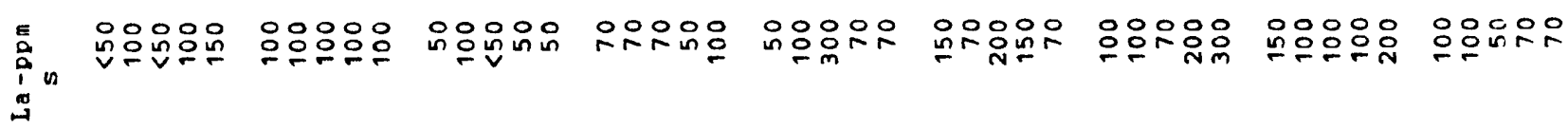

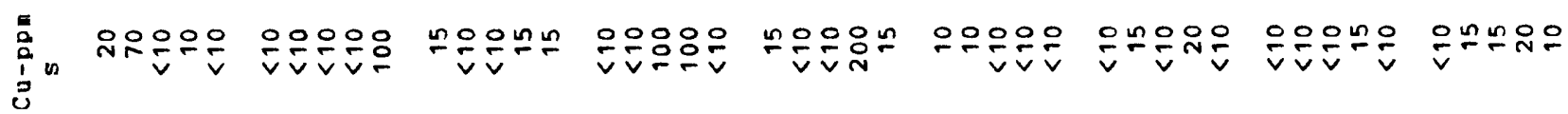
E

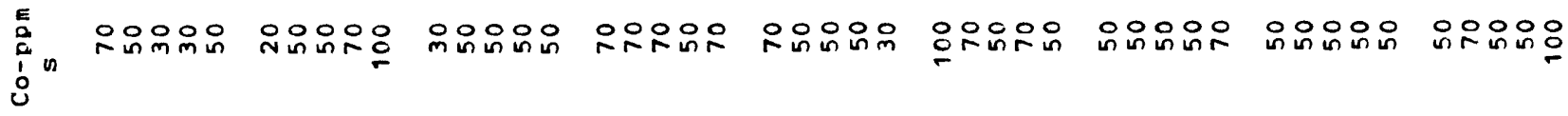

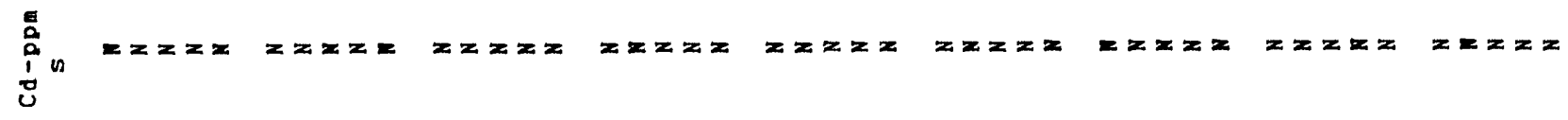

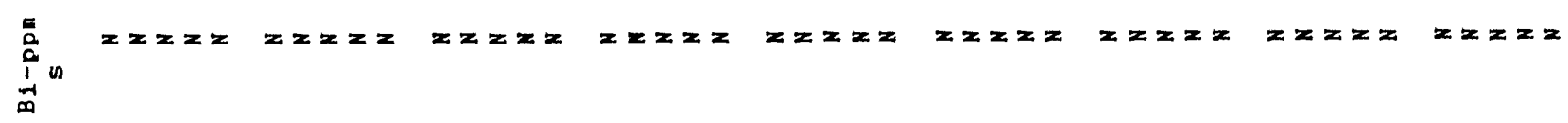
0
0
0
0
0

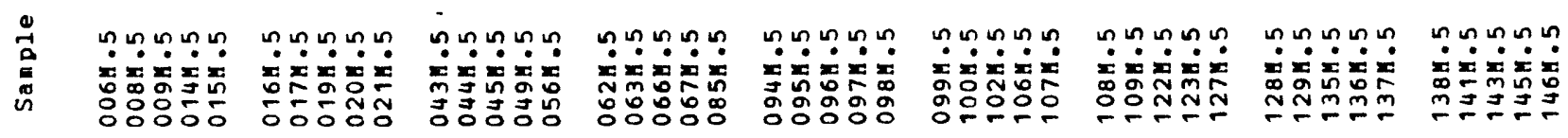


总

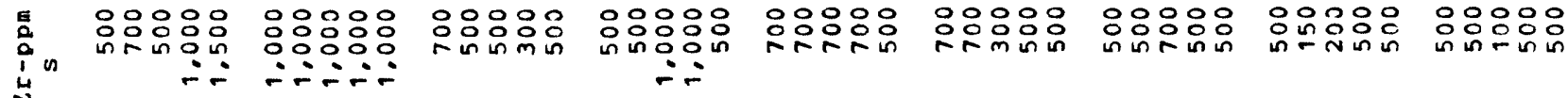

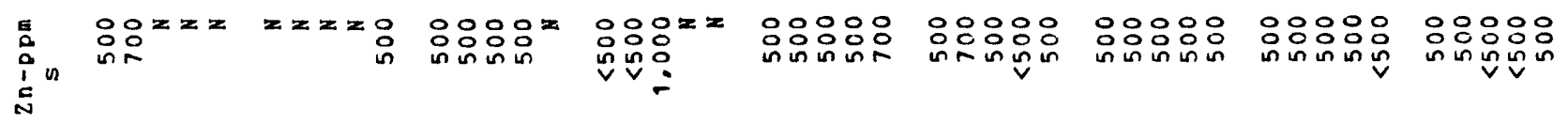
텃 있

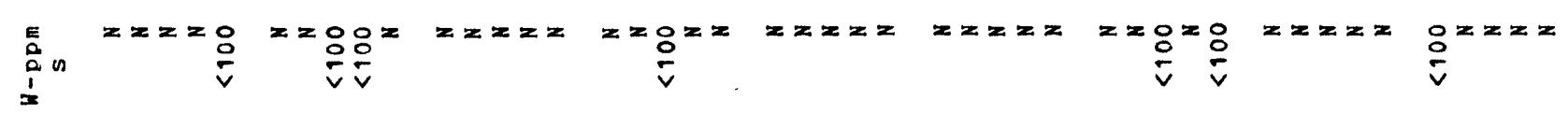

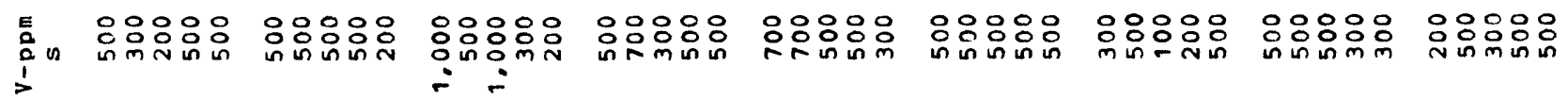

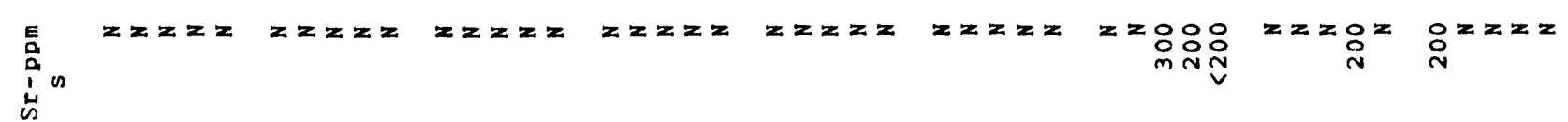

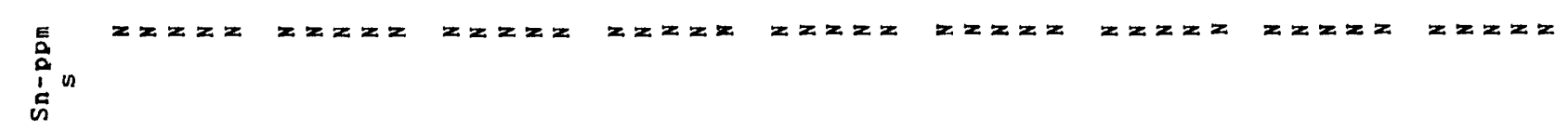

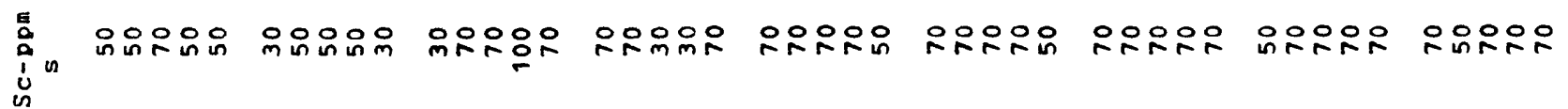

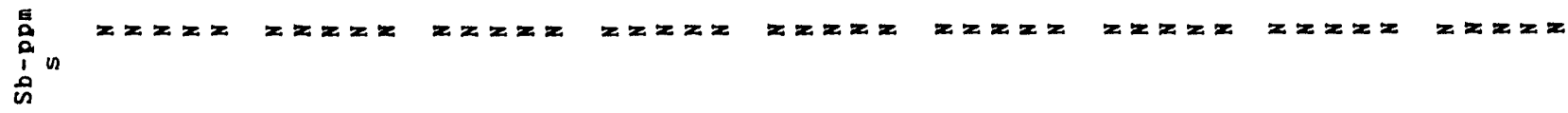

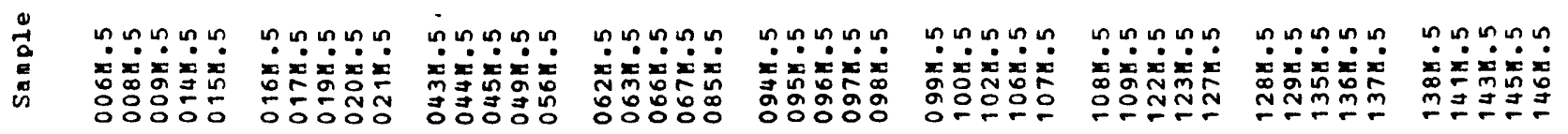




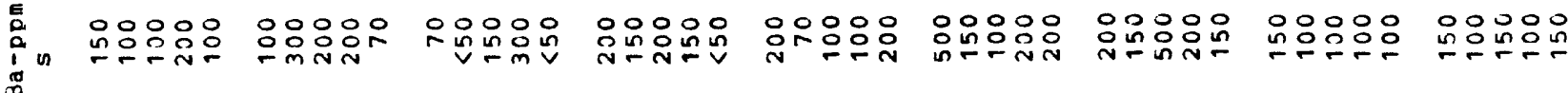

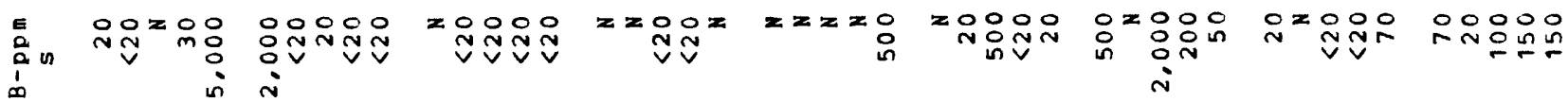

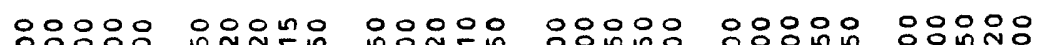

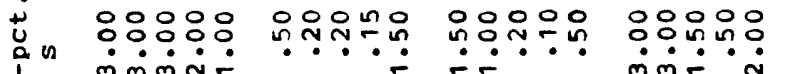

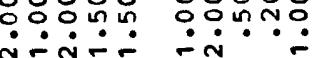

$\therefore \circ: \circ:$

응ㅇㅇㅇ 응요용 ชี

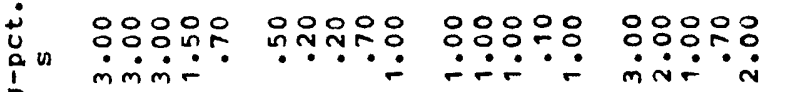

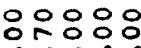

융요유요 minima

$\dot{m} \dot{\sim} \dot{n} \dot{m} \dot{m} \dot{m} \dot{m} \dot{m} \dot{m}$

:

$\dot{n} \dot{m} \dot{m}$

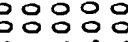

inंतिं

$\therefore: 00: 80000$

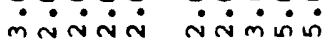

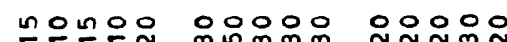

00000

onooo oOoOo

웅요응

은ํํํำ 유늠ํㅇ is

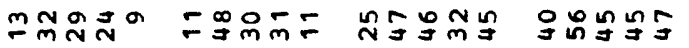

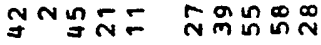

กำกำกี

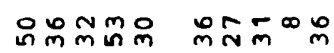

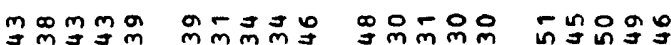

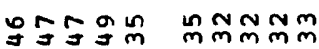

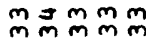

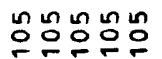

กnแn $n$

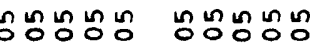

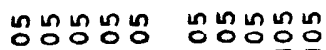

ํํㅇํํㅇํㅇํํㅇํㅇ

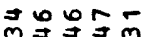

可的的单

in

우웅ㅇㅇ 우으으으으 우웅ㅇㅇㅇ

웅유

웅ㅇㅇ

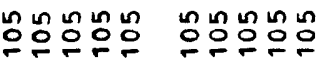

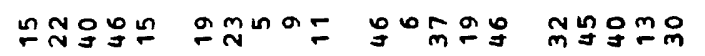

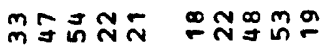

등ํำ-

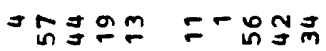

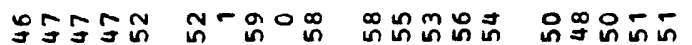

的的的的

的员骂昌昌

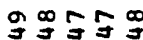

叧寻寻举可

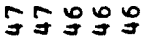

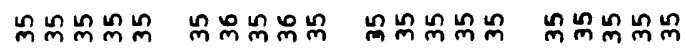

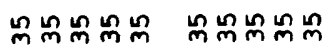

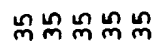

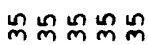

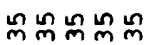

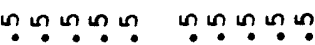

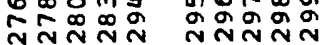




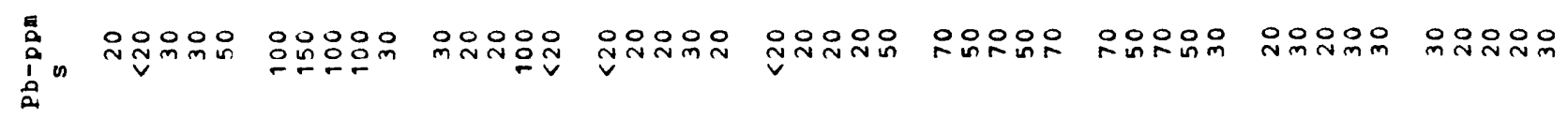

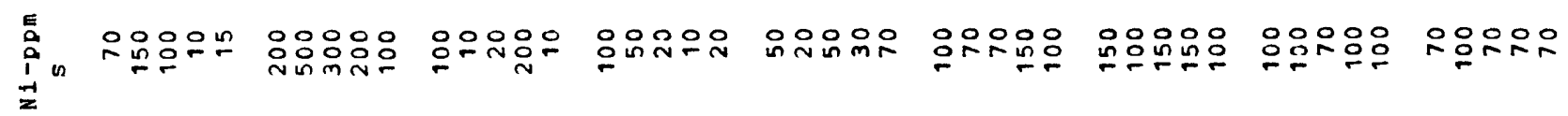

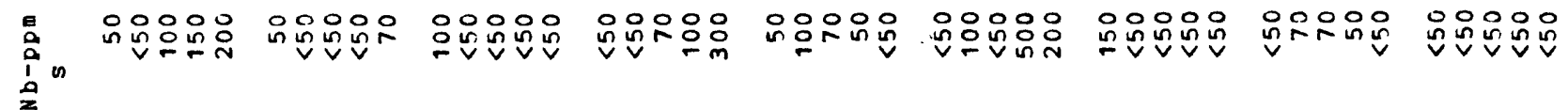

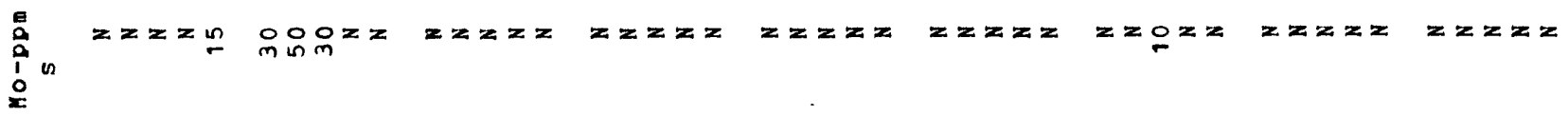

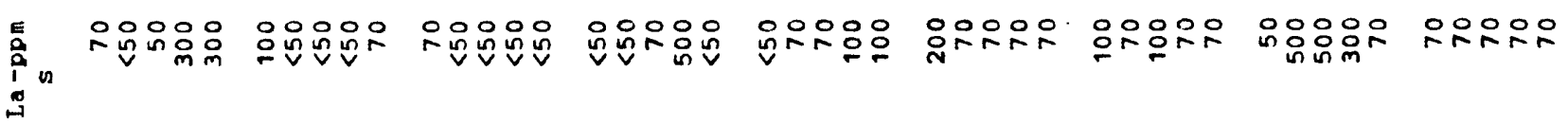

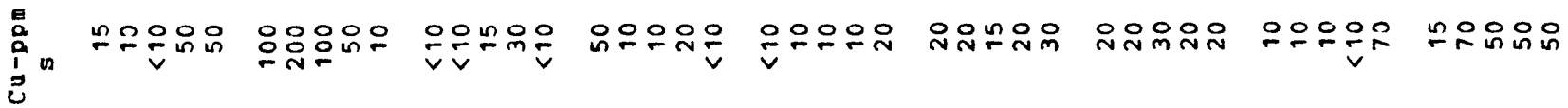

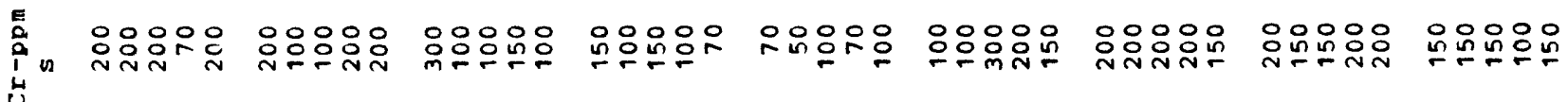

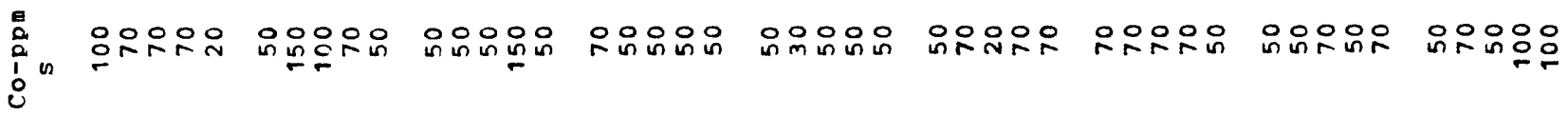

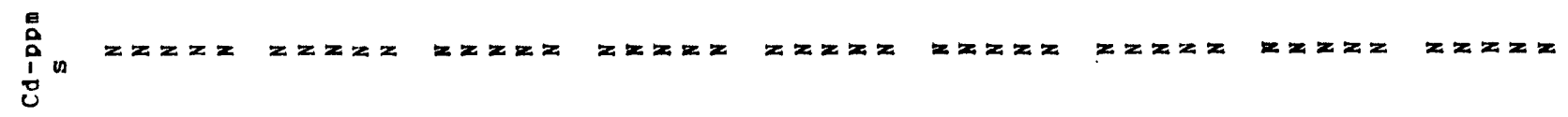

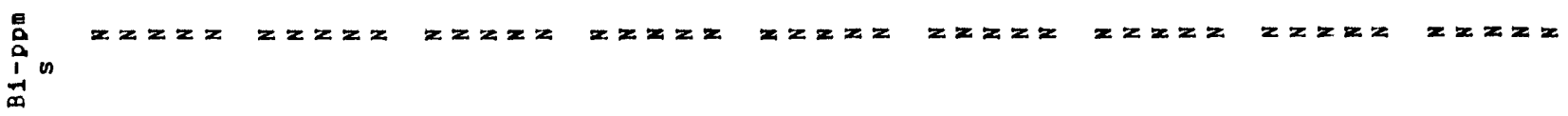

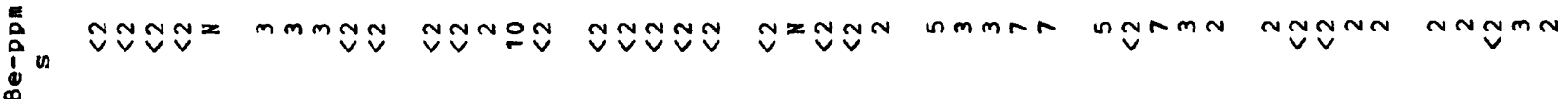

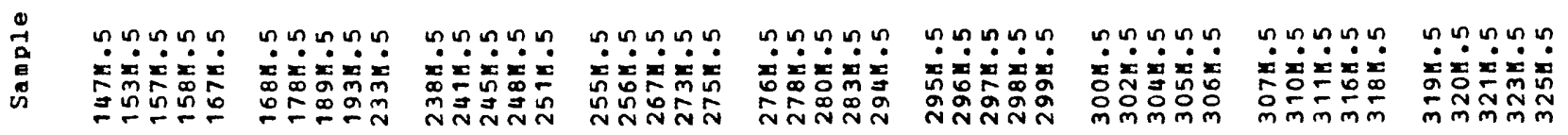




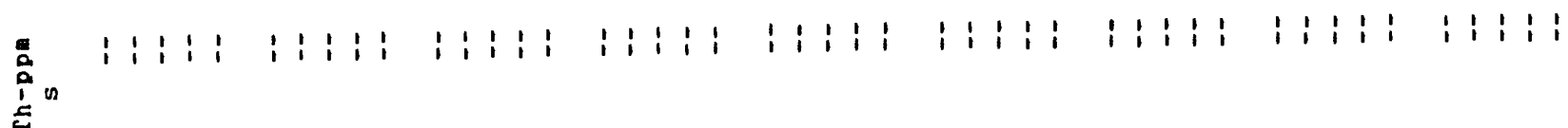

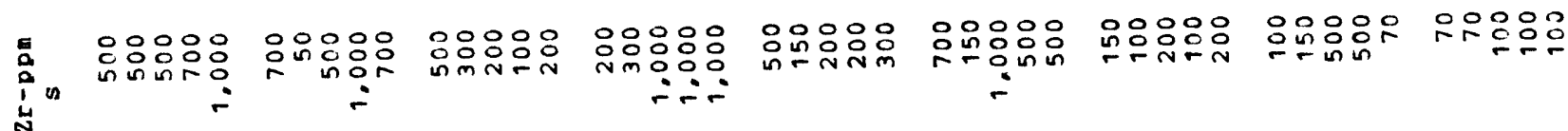

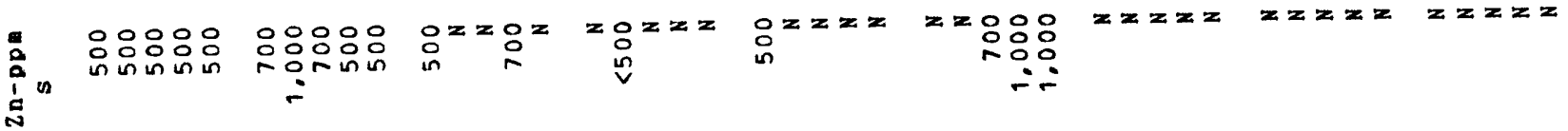

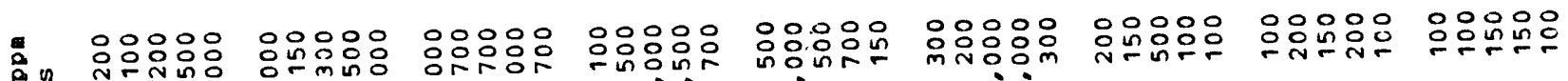
$i$
0 n

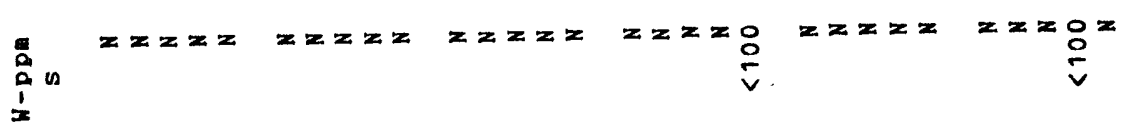

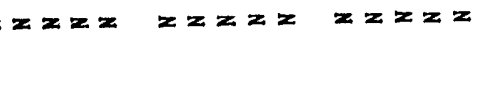

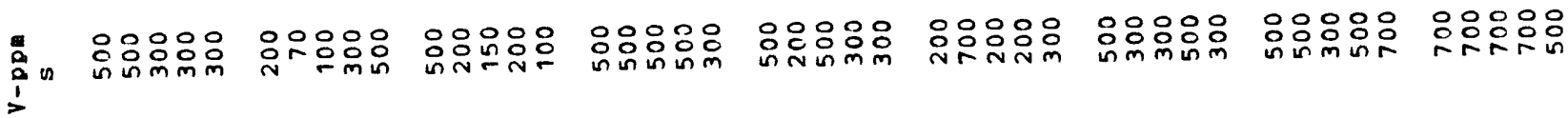

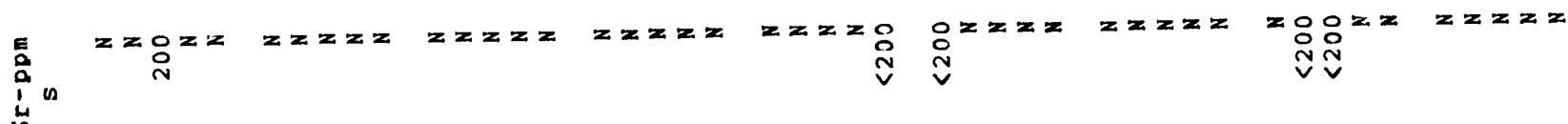

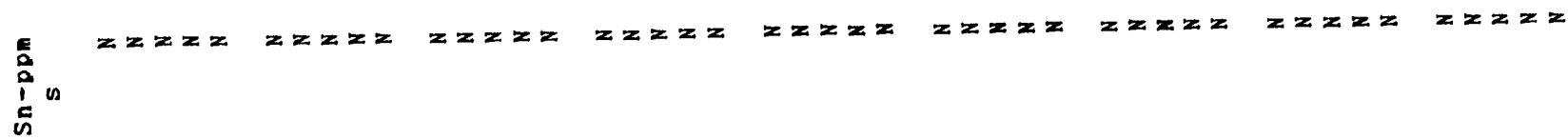

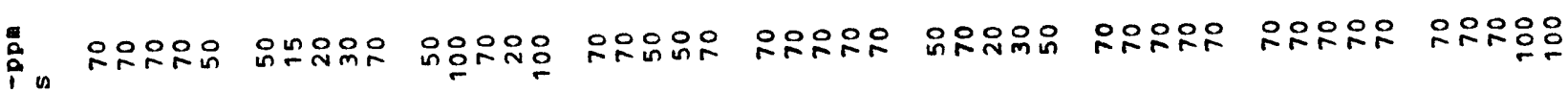
is

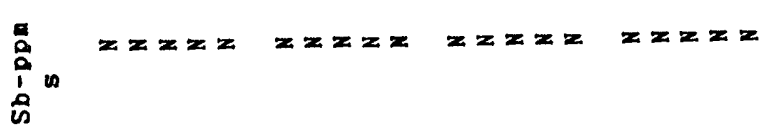
$\stackrel{0}{2}$

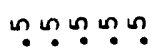
กำก ก ก
กับกษก

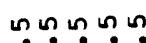
แก แก แก แ

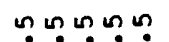
แก ?ำ
?ก? ?ำ
กำ กำ
天立家家 


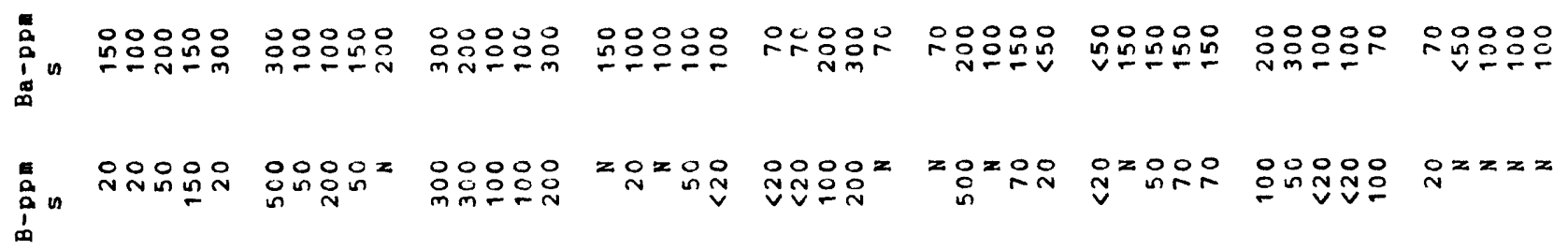

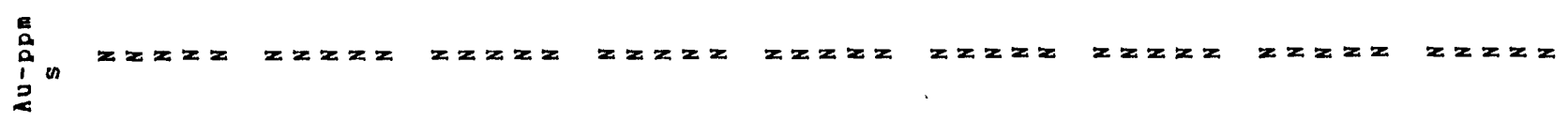

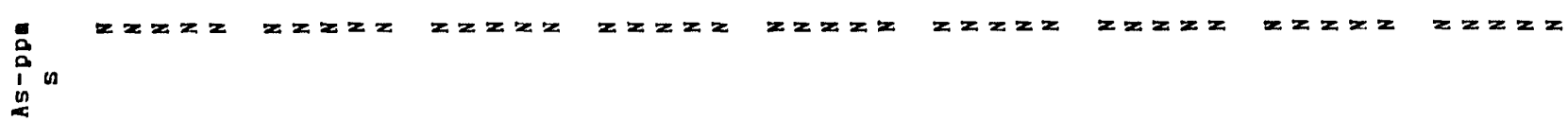

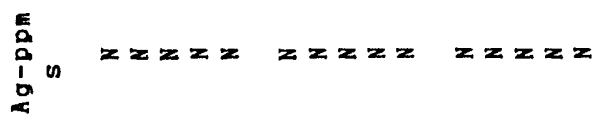
$z=z x$ $z=z z$ $z z z z$ $z z z z$ $z z z z z z z z z$ 至

응요영 00000 응ㅇㅇㅇㅇㅇㅇ

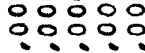
ninin rorin

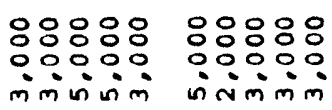
용ㅇㅇㅇ

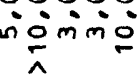

응유유 무요요

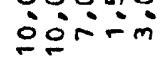

ㅇ:유 응응우운 inis

응응ㅇㅇㅇ

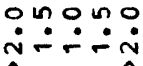

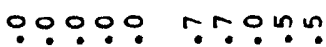

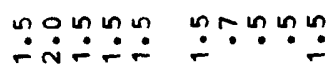
nin तิ 1

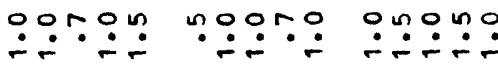
intri<smiles>C1CCCC1</smiles>
몀ํํ 응응요 염움윤운

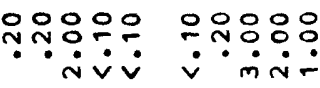

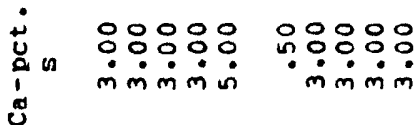
$\because \because 8 \%$ min

$\dot{0}$
0
$\vdots$
$\vdots$
$\vdots$

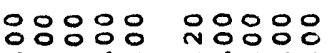
웅응은

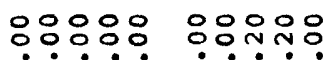
옹용요요 운융으운

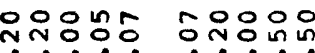
inisinis mismin minis

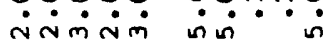
- ín $\because \div$ i். ن뭉

으우앙ㅇ 융윰ㅇ 으으웅요 으으으으 아윰유 으우우는 느으우능ㅇㅇ

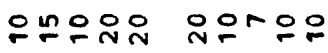

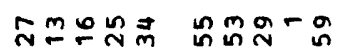

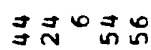
พั

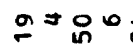

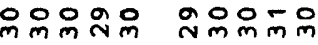
ํํํำำก กักลำ 운ํํำำ งกำษ

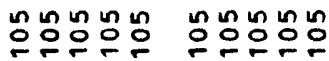
응응ㅇํ융유 응ํํㅇํํㅇํํㅇํㅇ 농ํํ융ํㅇ응

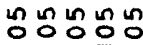

올의

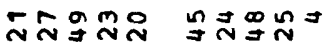
急寻寻市品 웄옹우

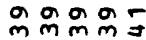
in 电

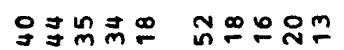
สีสำกำ

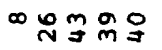

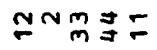
กัก

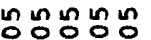

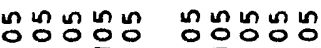

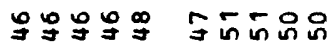
응ํㅇㅇㅝ

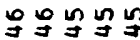
घำำํำ 经品与药出

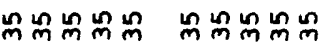

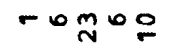

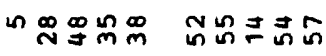
站的 $N$

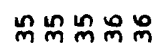

กแONO O-NE⿱⺊口冋

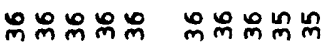

กำก ก ก 


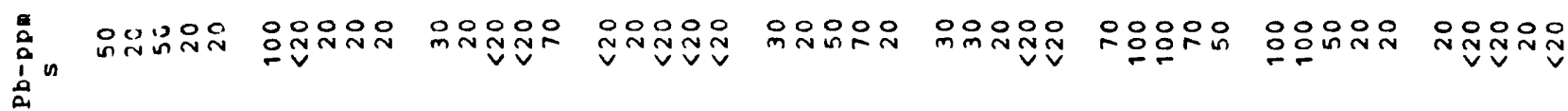

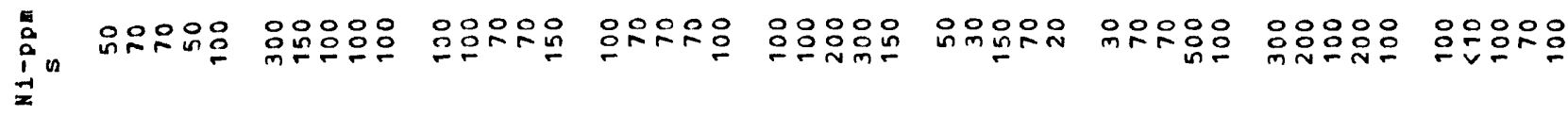

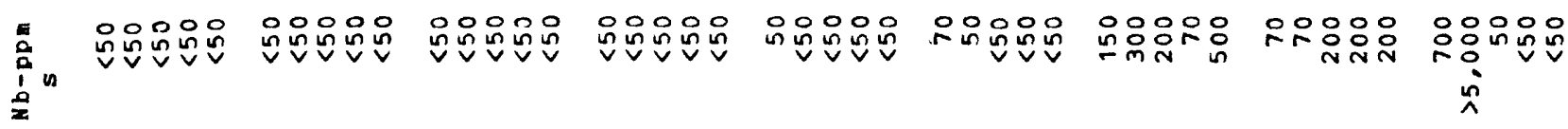

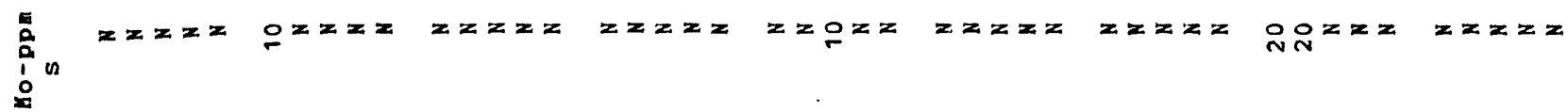

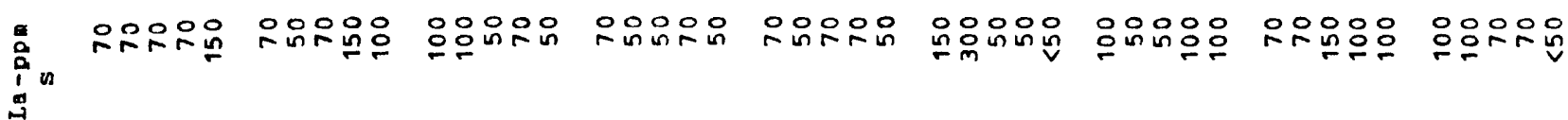

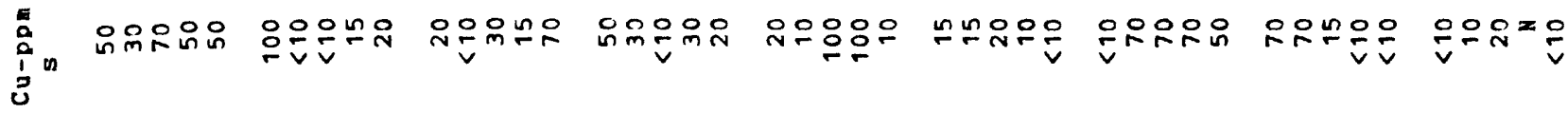

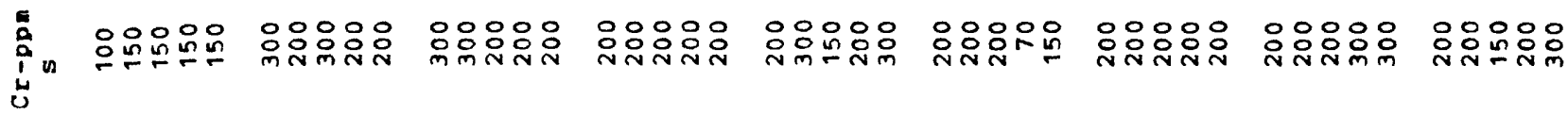

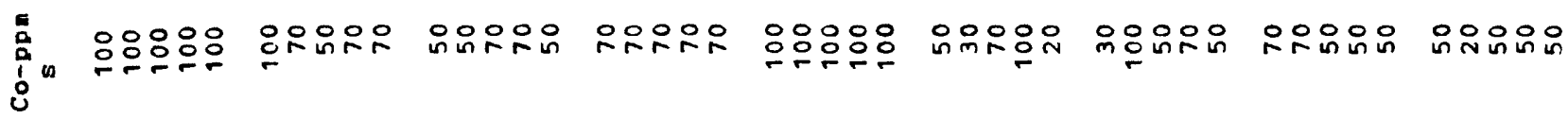

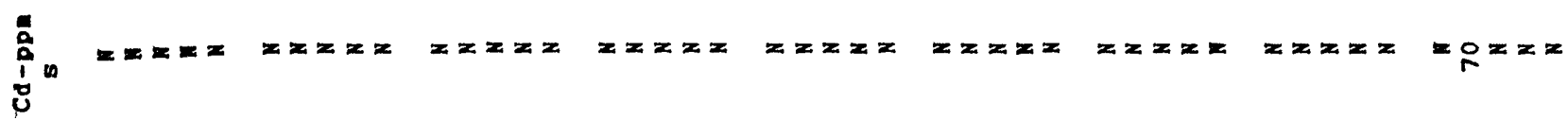

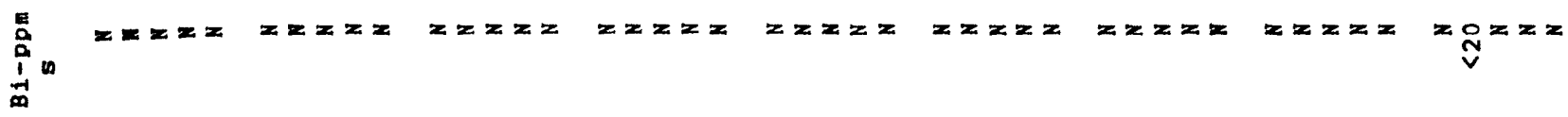

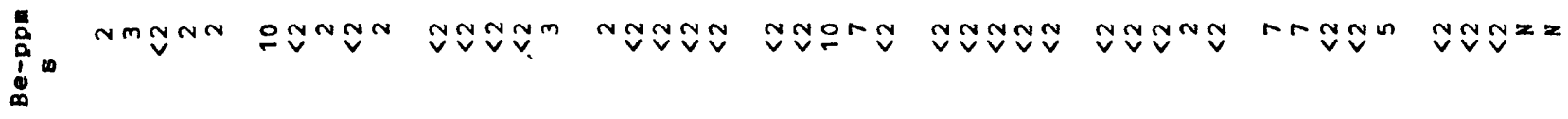

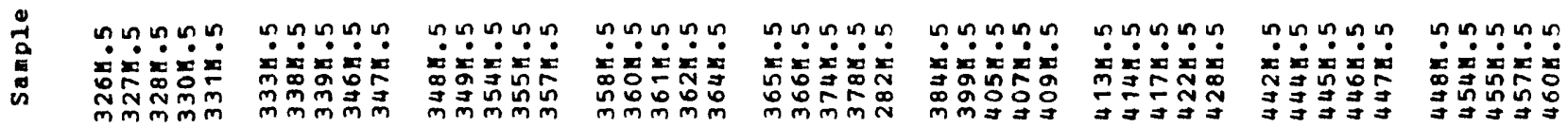




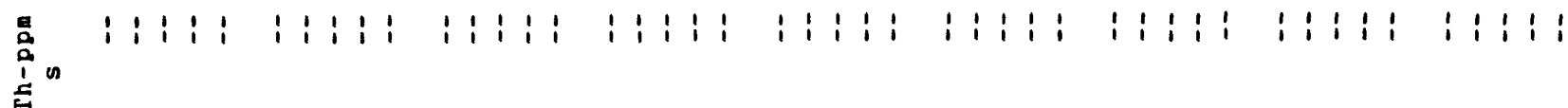

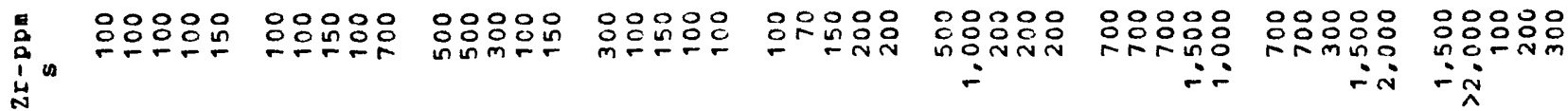

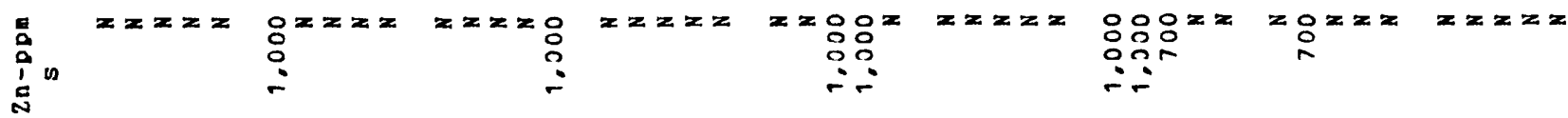

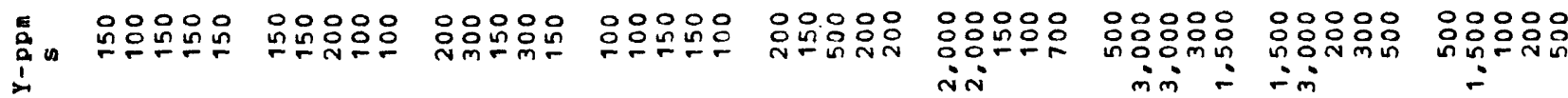

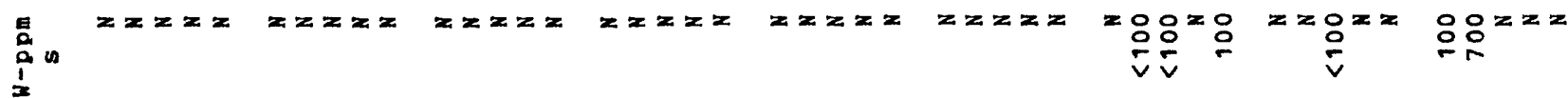

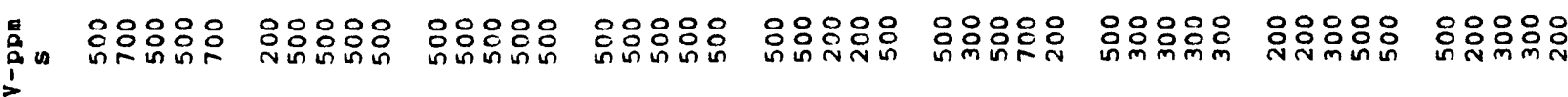

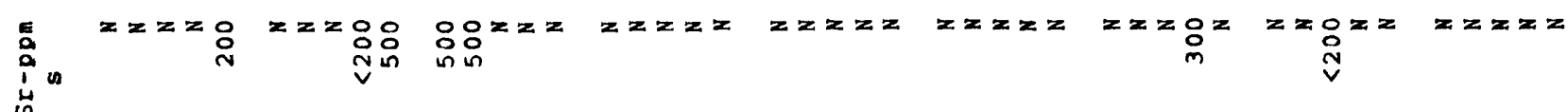

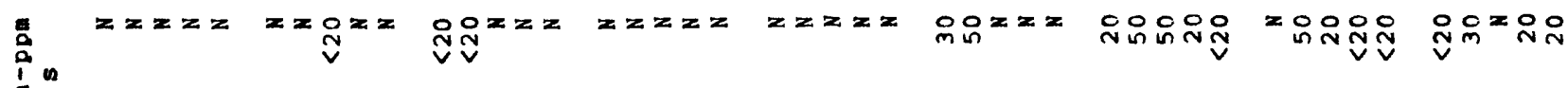

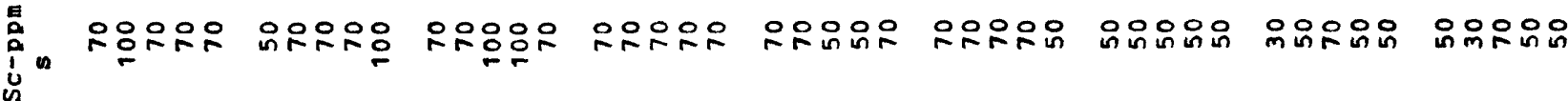

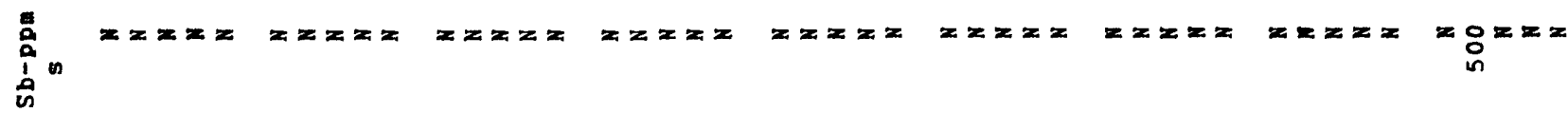
年 


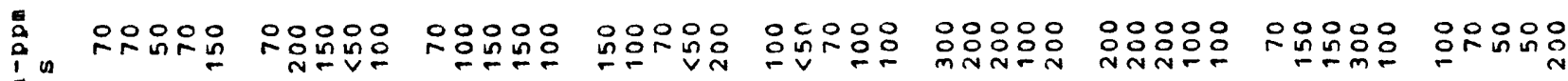

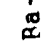

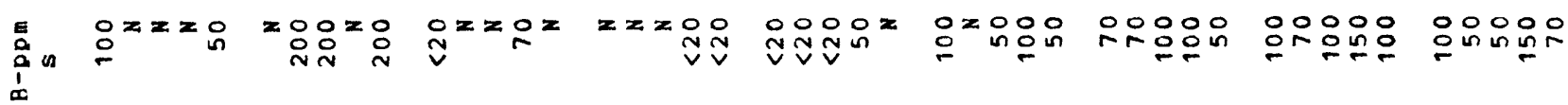

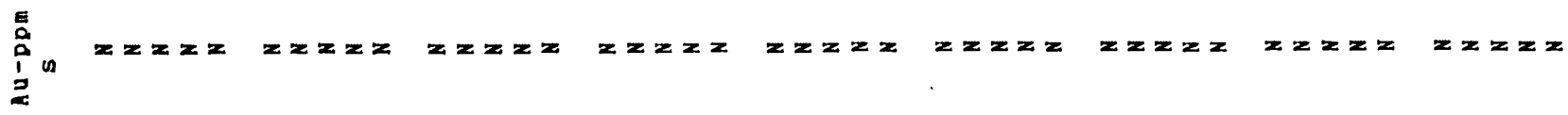

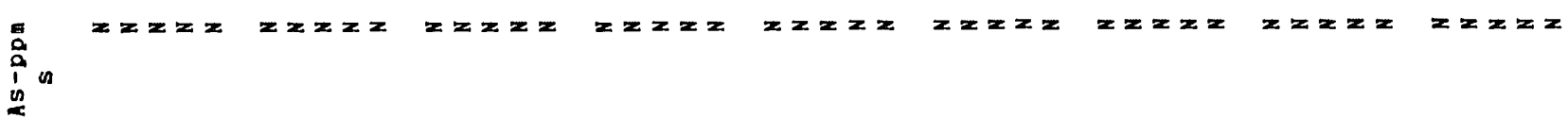
否

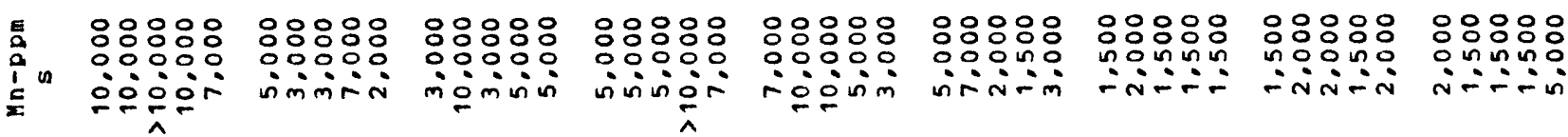
苟 $\rightarrow$

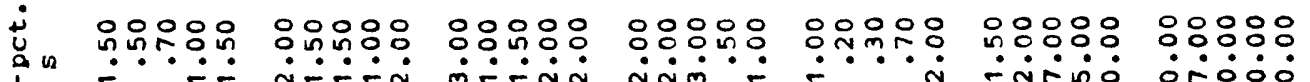

Ninं -

$\therefore$

$\therefore$ inis

숭ㅇㅇㅇ

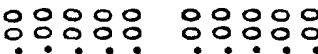

ช

苦

응응응 융요웅

응응요응

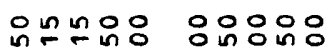

응응응

$\dot{\sim} \dot{N} \because \because \dot{N} \because \dot{\sim} \dot{\sim} \dot{\sim} \dot{N}$

กํ.

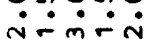

Ninisin

응ㅇㅇㅇ 응응응 $\dot{0}$
0
0
0
0
0
0
0
0
0
0
0
0

ㅇo잉

noooo

응oㅇ

rrmog

은뜬 r은유는

உேッ゚ே

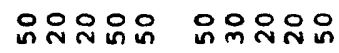

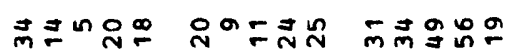

งี้อักลี

กัก路웅

$m \underline{m}=0$ in

Nํำก은

₹잉요

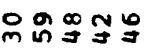
โ⿻彐丨 चैच寻寻寻

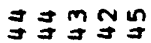

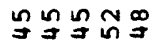
串的寻寻 $\exists \exists \stackrel{\infty}{\exists} \underset{\exists}{\infty}$

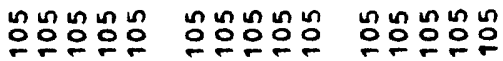

능ํํㅇํํㅇํㅇํㅇ

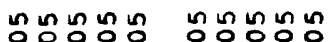

agago

的角罗星

只哟的的

$\dot{n}$

$\infty$

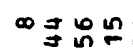

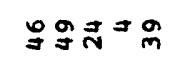

ํำ (

ํํㅇํํㅇํㅇㅇํㅇ

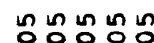

nnun 으우으으으 으우우응 느으

우웅ㅇㅇ

으우우유

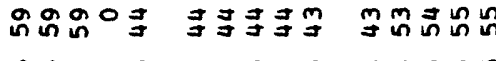

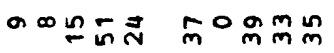

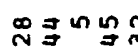

로요

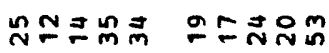

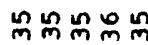

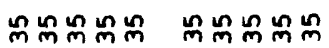

m承苯经

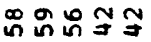

곸ㅍ

泣戸5

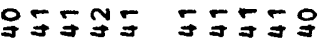

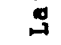

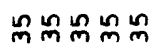

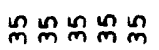

品紫紫品

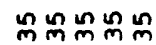

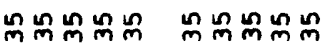

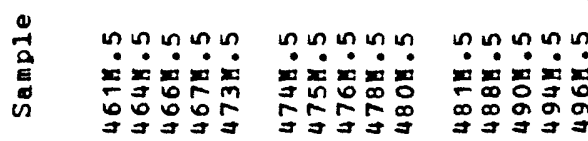

นกำกำ

กุกนกฺ

กำกฺน

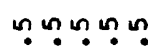

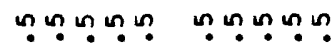

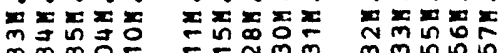

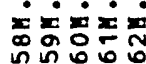
安家安

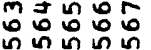

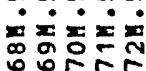

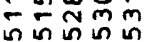

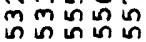




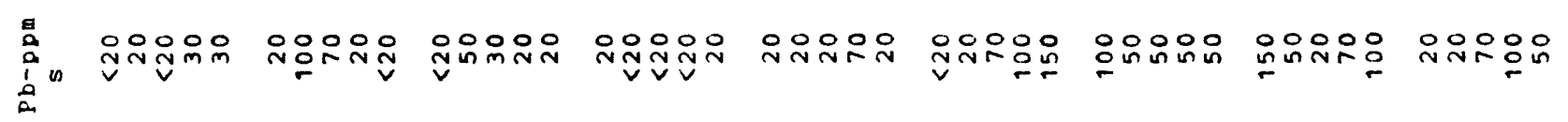

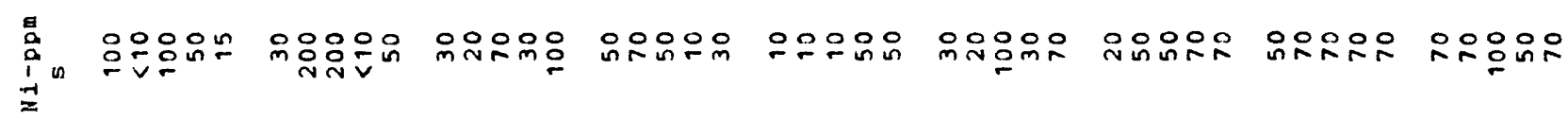

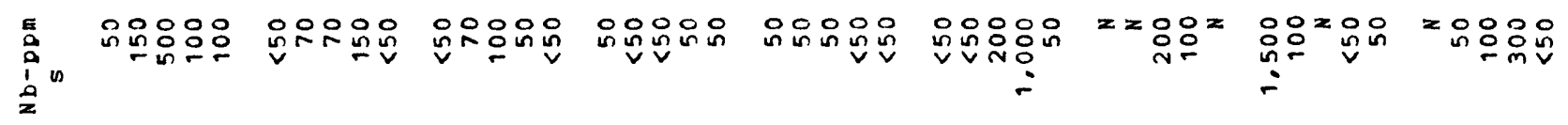

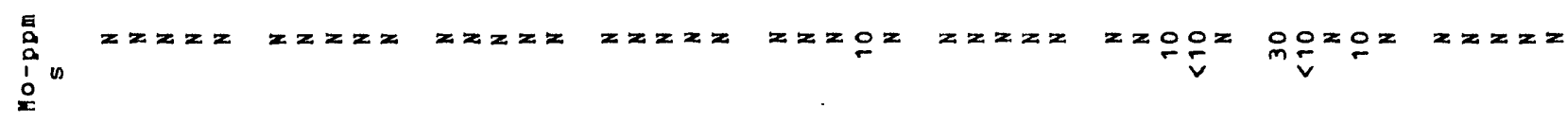

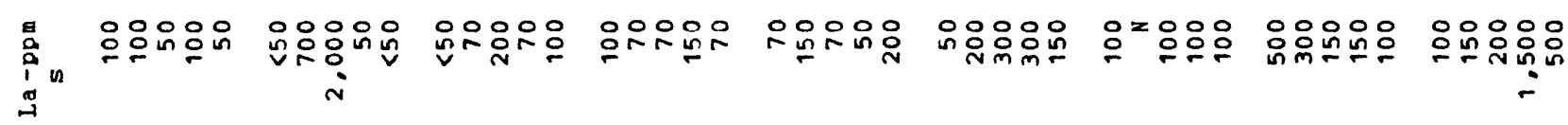

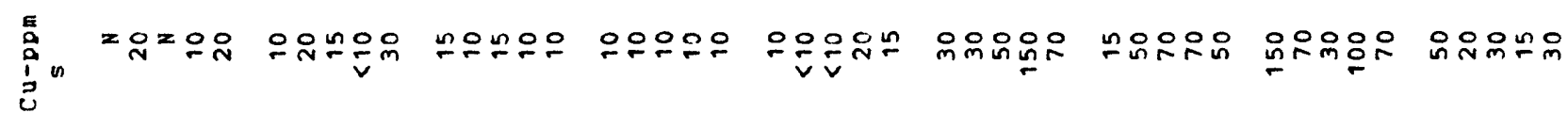

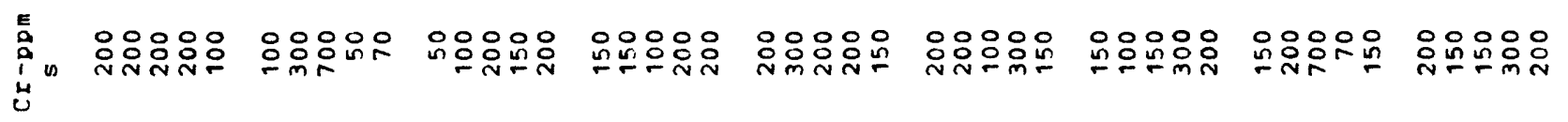

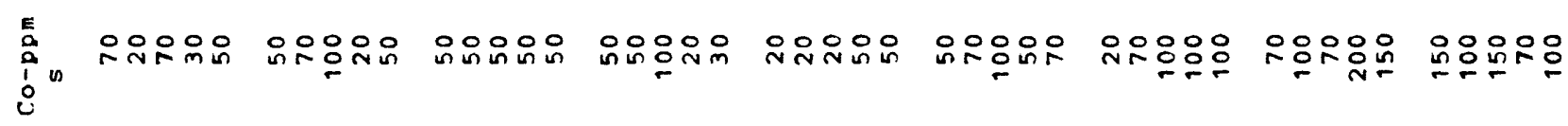

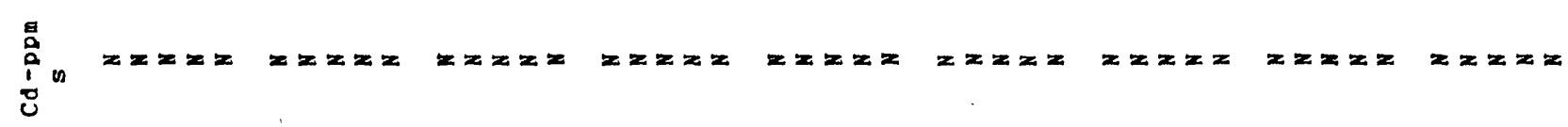

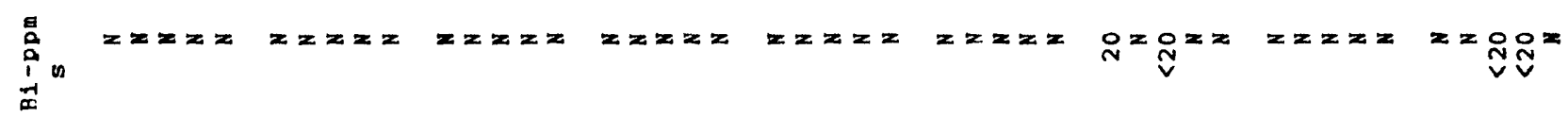

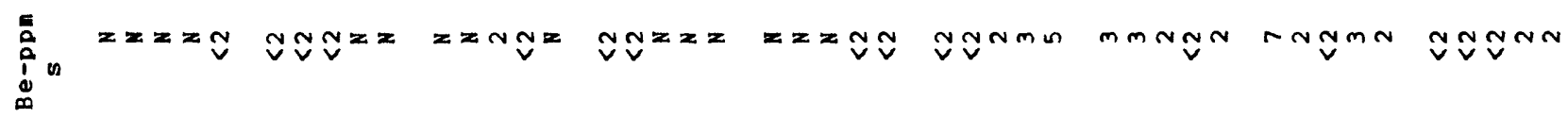

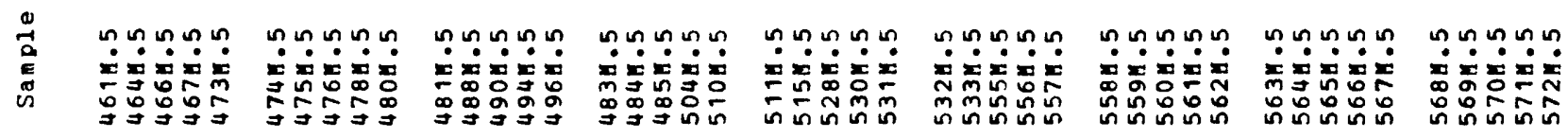




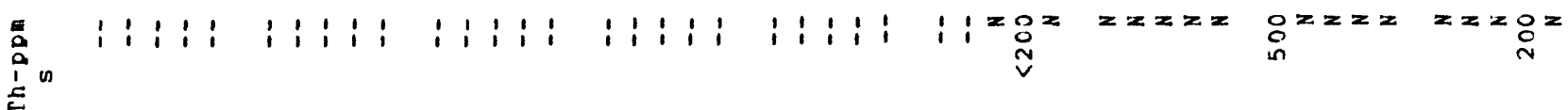
E

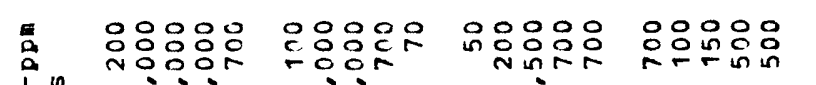

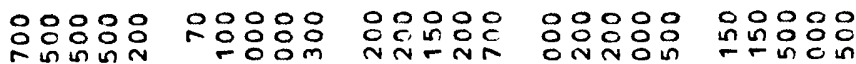
$\because \because$ nin $\therefore$

inin in

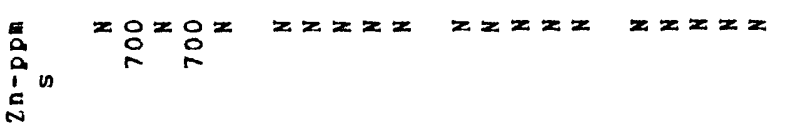

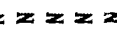

$z z z z$

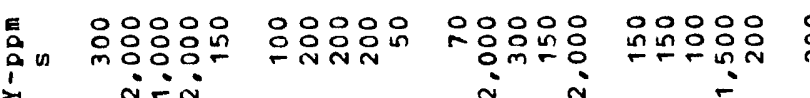

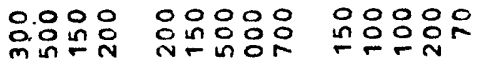

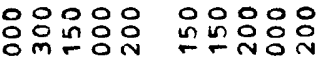
nin

N

$\therefore$

m

in $=$

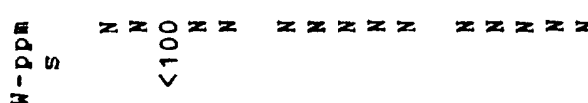

$x=x z$

$z=2 x$

$z x z z$

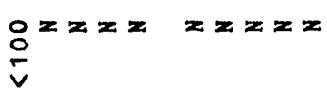

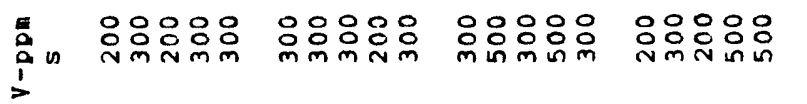

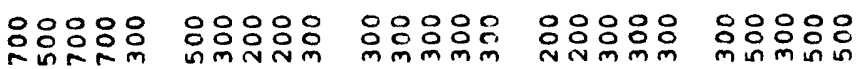

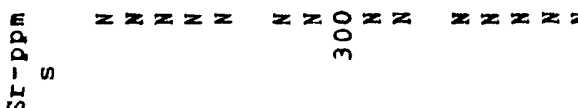

$\mathrm{O}^{2}=x$

$x=x$

$z=0 \geq 0$

응응응응요

응ㅇㅇㅇㅇㅇㅇㅇ 응영ㅇㅇㅇㅇㅇㅇ

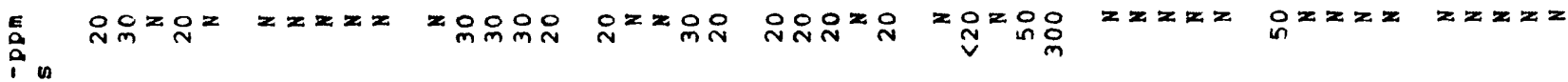

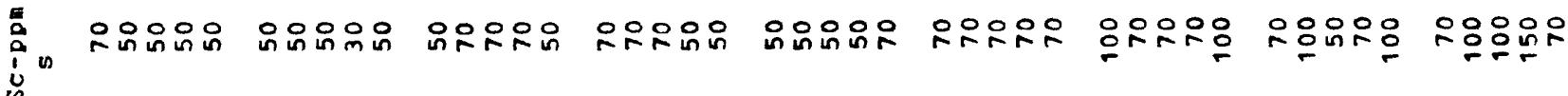
in

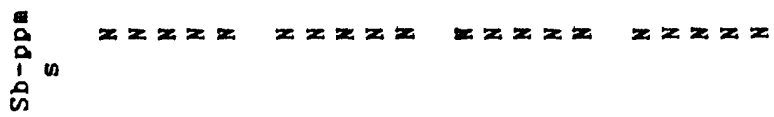

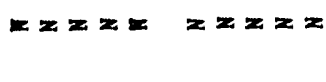

$x=2 x$

$z x z z z=2 x z$

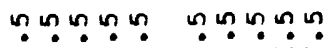

กัก แn

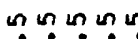

กำ ก ก ก

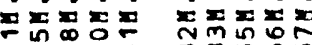

중종

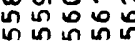

포요

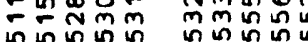

㶽品品品

约经战的 


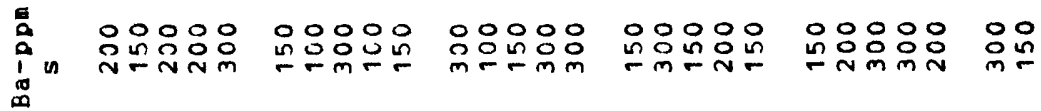

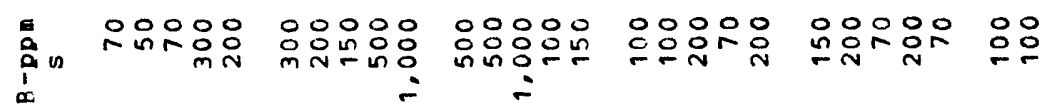

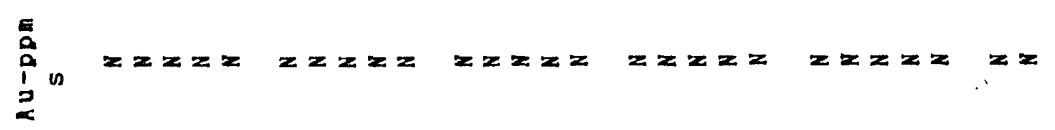

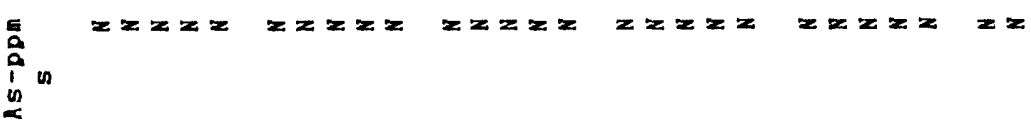

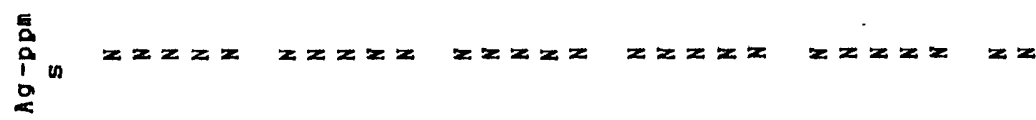

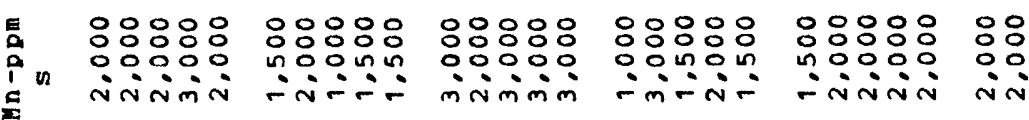

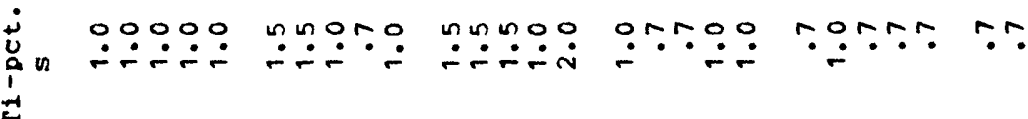
E-1

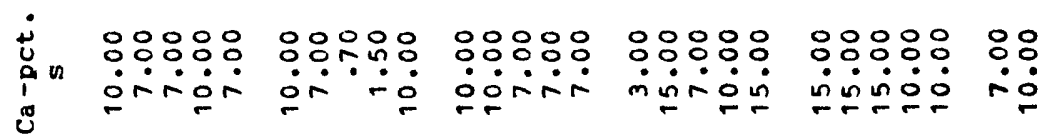

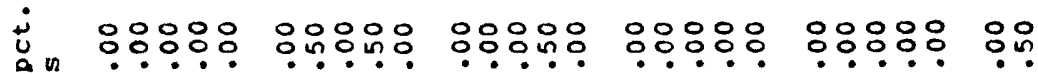
î

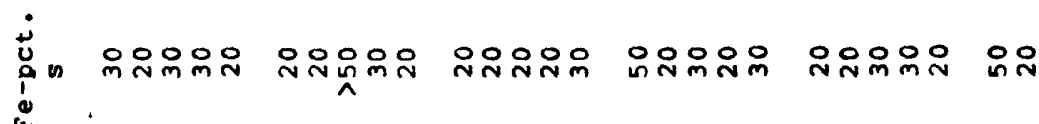

\begin{tabular}{|c|c|c|c|c|}
\hline 艛 in & 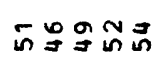 & 옴쇼요요 & 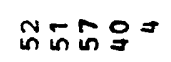 & ดำ \\
\hline 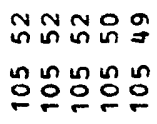 & 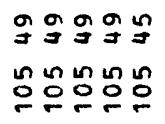 & 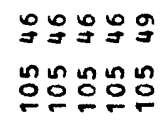 & 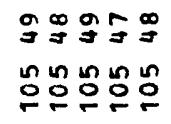 & 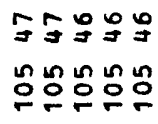 \\
\hline$\stackrel{n}{m} \stackrel{n}{m} \stackrel{\infty}{g} \infty$ & 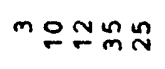 & $\stackrel{\circ}{2} a^{\circ} \bar{m}$ & garni & 픔요 \\
\hline 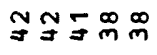 & 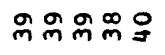 & 욱웅요욤 & 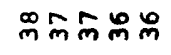 & 윰이 \\
\hline 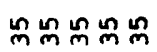 & 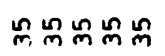 & ్ㅛ & 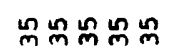 & 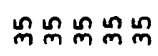 \\
\hline
\end{tabular}

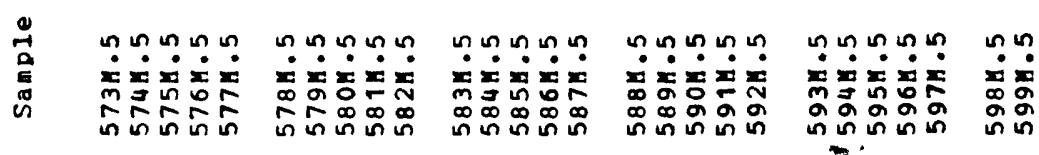


毠

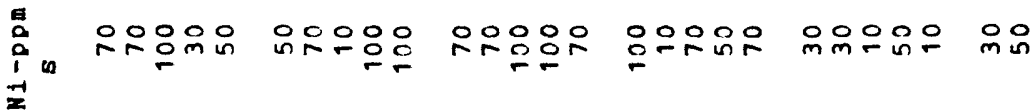

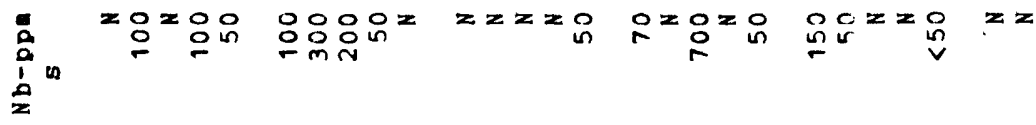

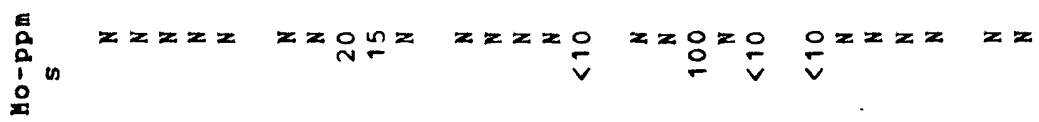

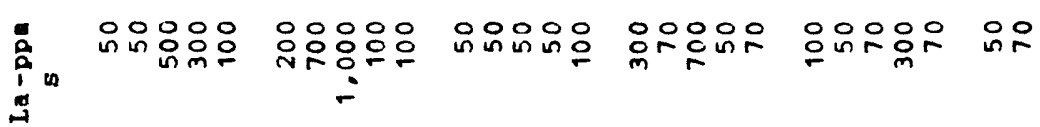

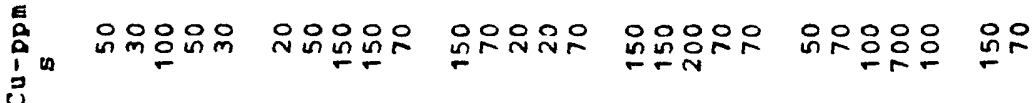

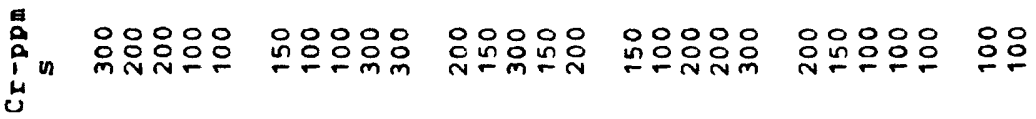

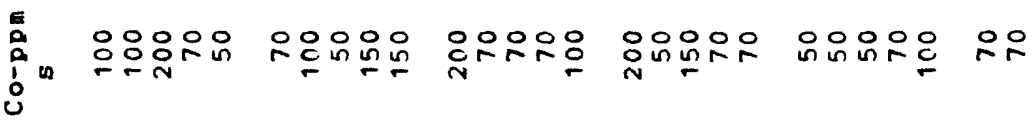
${ }_{0}^{\frac{1}{0}}$ ㄴ.

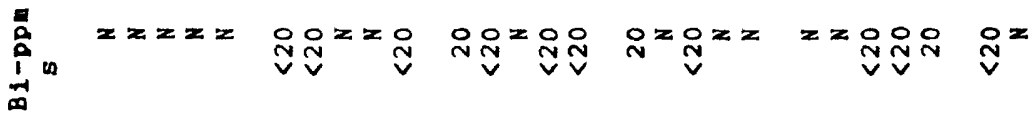

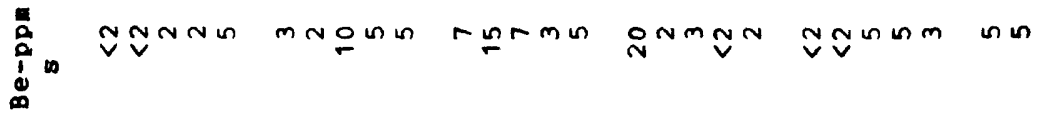

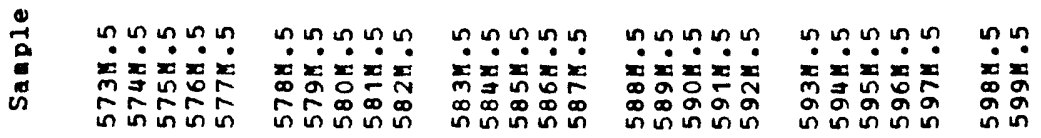




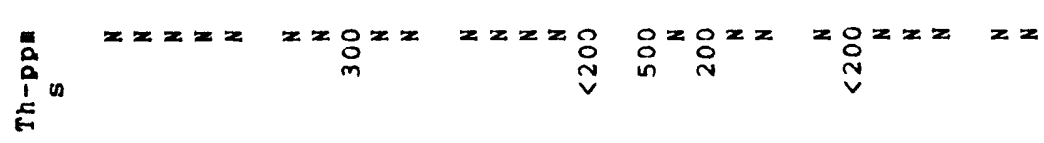

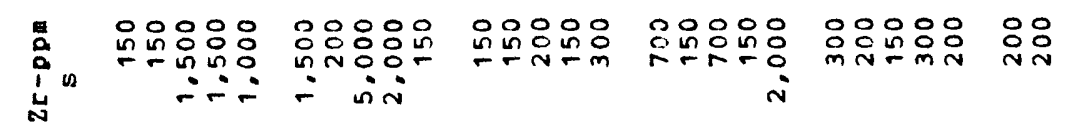

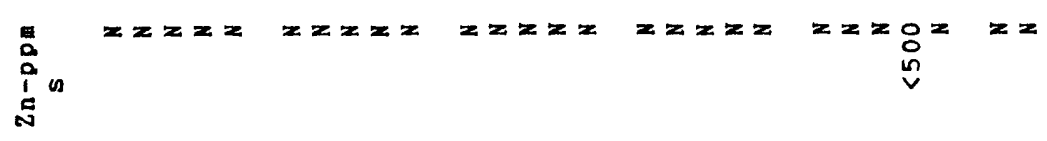

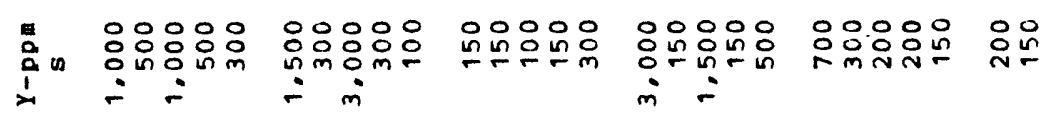

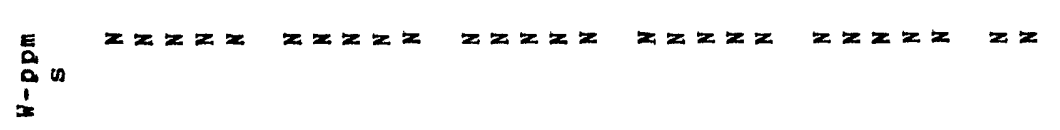

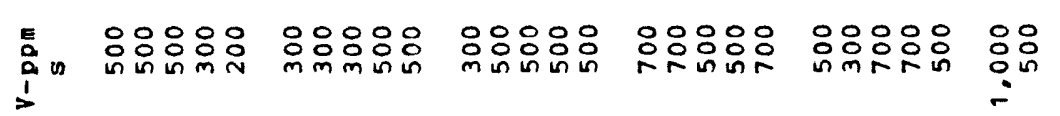

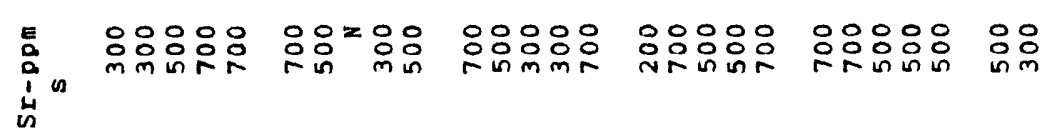

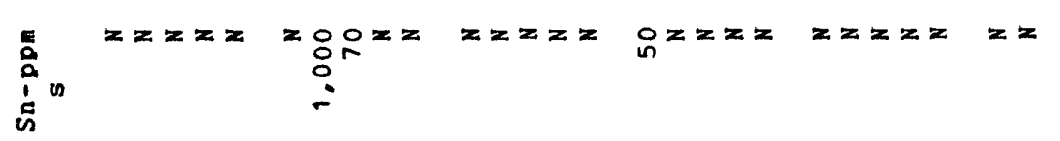
0

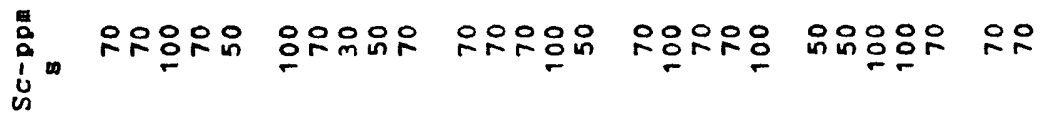

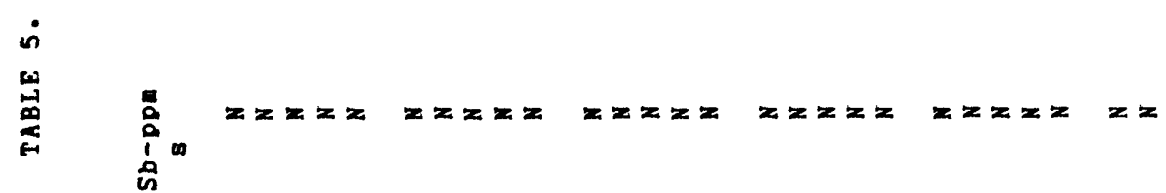

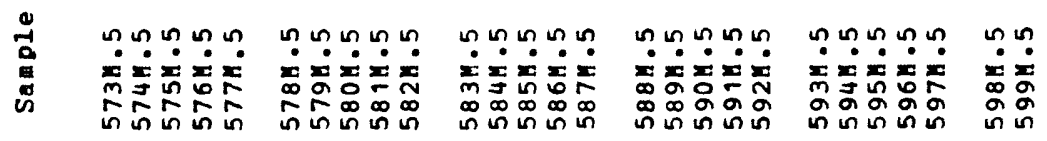


1. 0000

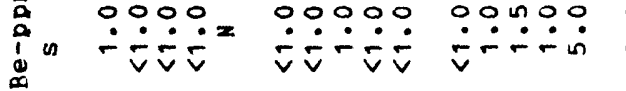

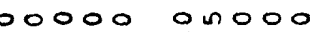

on 0 ก

$\ln 0,0$ in 0

00 . 0.0

00000

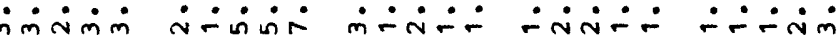

vimi்

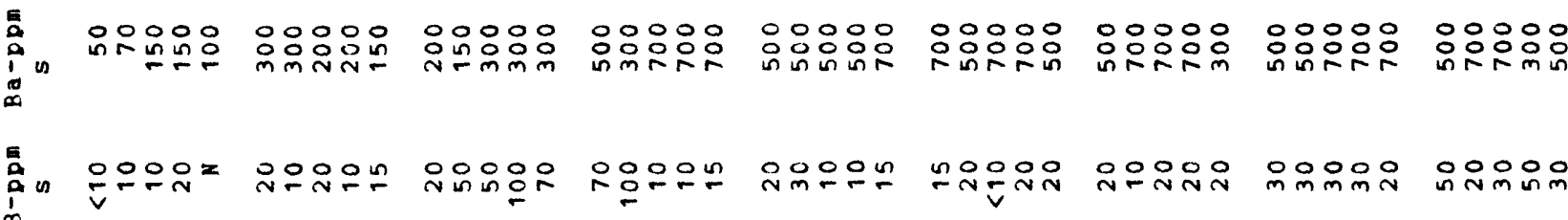

:

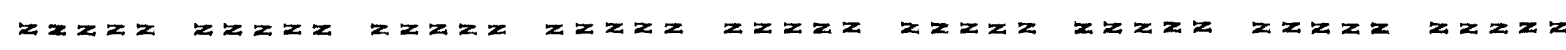

$z x z y z \quad z z z z y z z z y$ n

$z x z z \quad z z: 0 z$ $z z z z z$ $z z z z z$ $z z z z$ $z z z z z$ $z z z z z$ $z x z z z$ $z z z z$ 咅电

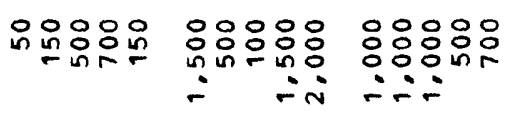

\section{웅융요}

용요융

응유 $\dot{4} \div=$ 웅요유: 응유유

응융응

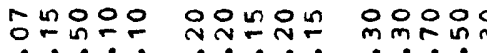

o on 0

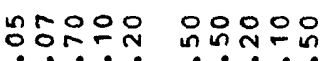

응응응

웅웅ㅇㅇㅇㅇㅇ

응응요운

$\because \because \dot{i}$

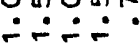

응우융응

$\therefore \because \dot{\sim}$

응용ㅇㅇㅇㅇ

$\dot{4} \dot{-\dot{4}}$

응웅ㅇㅇㅇ

तiं

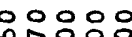

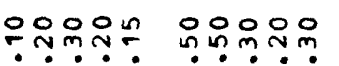
음오웅요

우ㄴㅜㅜ눙으

옹응요요

응응요

응요용응

웅응응

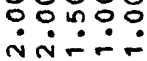

웅ㅇㅇㅇㅇㅠ $\because \because \therefore-$

$\therefore \therefore$

nintr

台

要

苔n

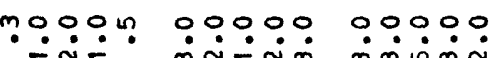

00000

00000

00000

00000

00000

00000

\section{ơngna am}

ถูกัดูก

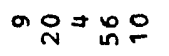

ำm

20

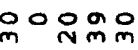

路ํㅗㅇ

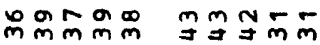

品品些可

$\exists \exists \stackrel{\infty}{\exists}$ 品

手昌昌品的

的解皇品

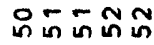

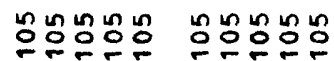

经经织误哭

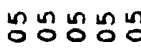

ํํㅇํํㅇํํㅇํํ융

ํํㅇํํㅇํㅇ융

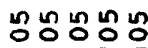

舫的果的

Nㅗㅇㅇㅁㅇㅢ

요뭉

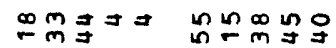

오포ำ

$\operatorname{gim} \min _{n \rightarrow-}$

路话解

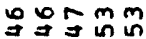

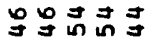

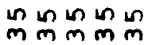

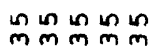

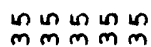

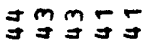

n $n$ nn $n$

zaon $n$

Nะกีะ

55550

in $n$ nn $n$

$2 \operatorname{lig}_{2}$

n $\ln$ in $\ln$

고ำำ

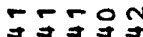

$m m m m$

m m m m

$\min \min i \min$

in $\min m \min$

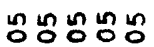

코ำํำ ogano

ํㅗㅇํํㅇํํ용용

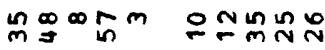
구요 m

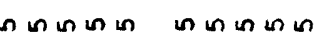

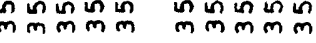

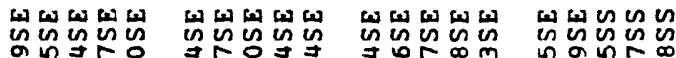

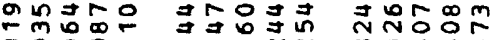

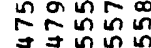

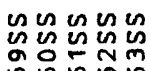

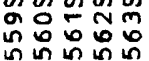

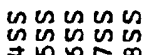

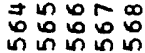

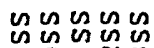

品足的的向

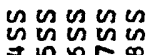

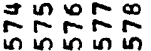

象此为照

aㅇ-

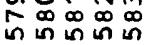




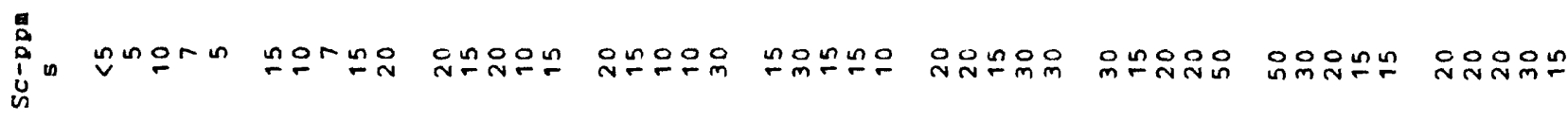

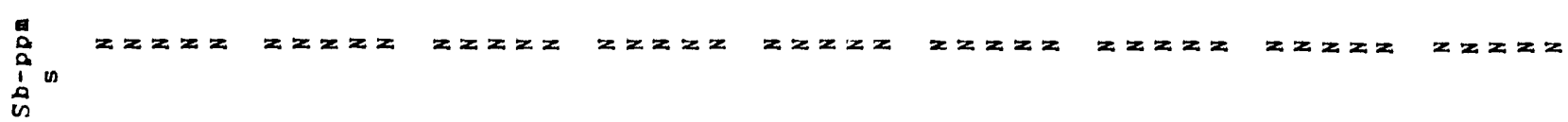

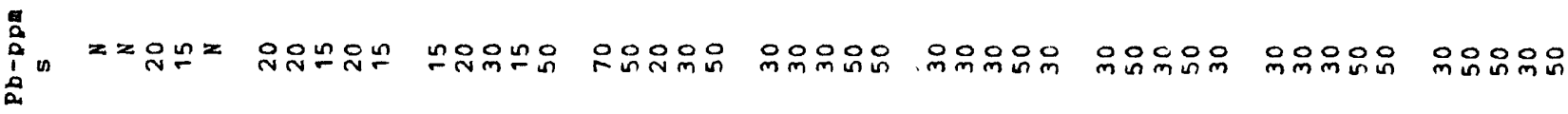

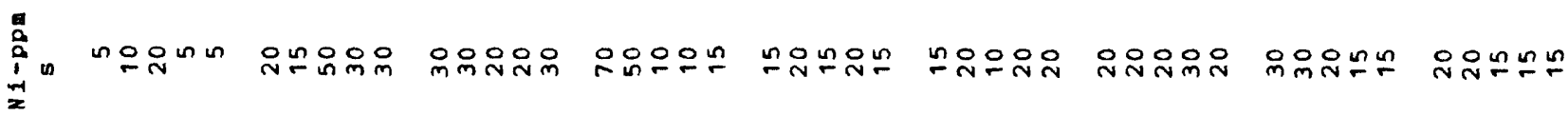

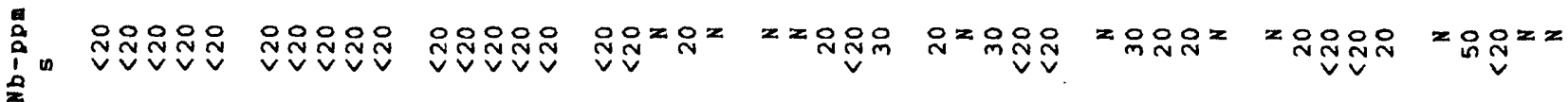

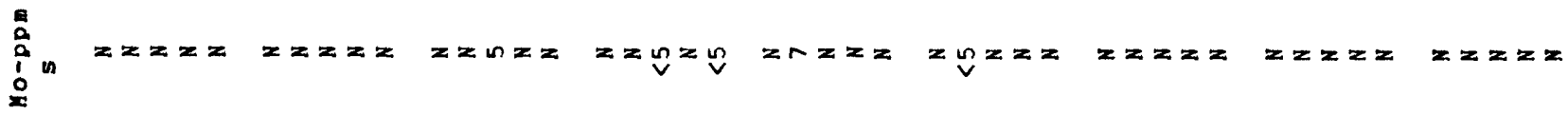

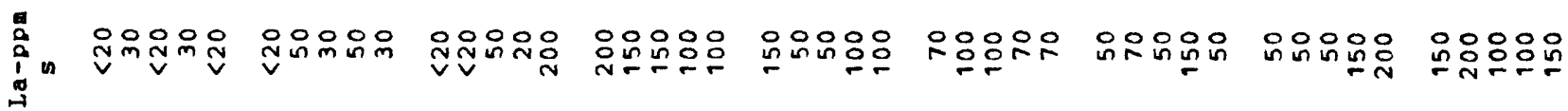

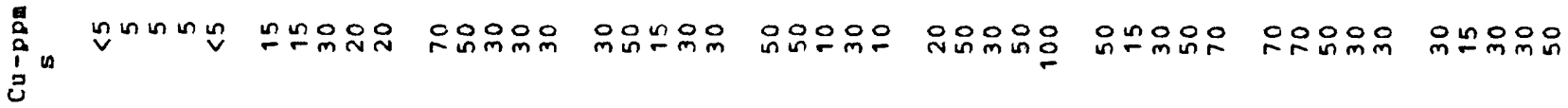

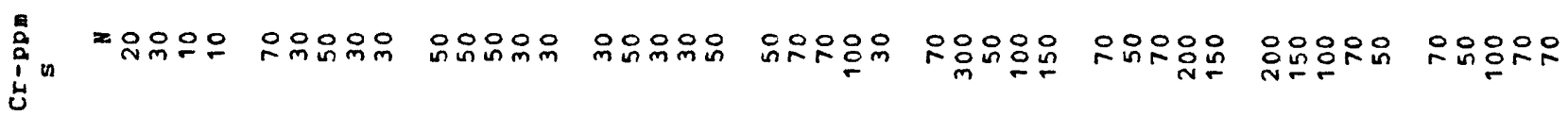

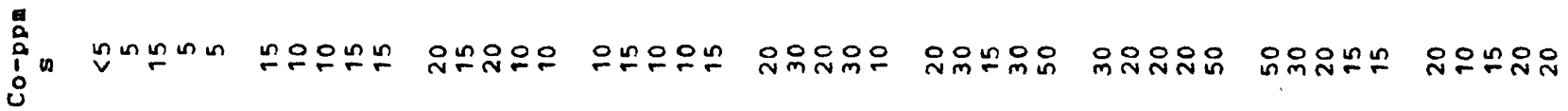

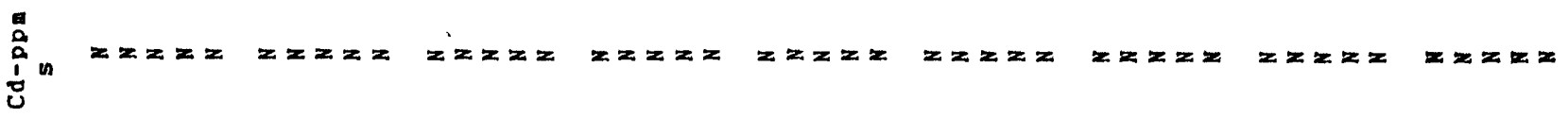

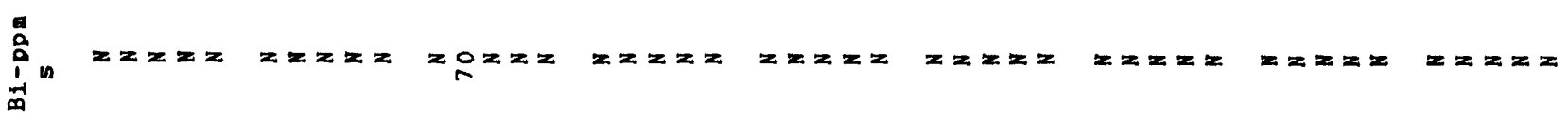




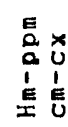

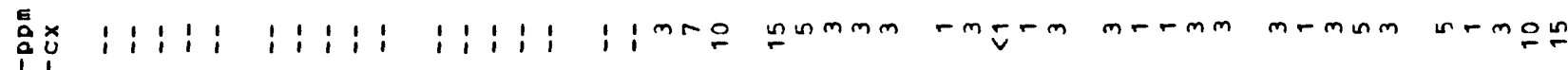
岂兒

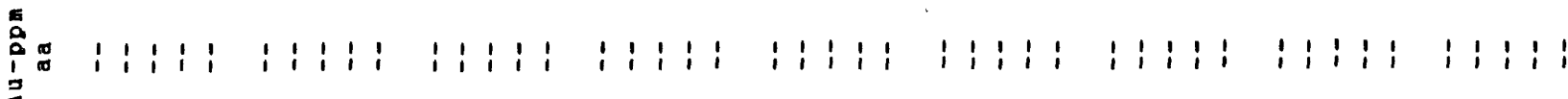

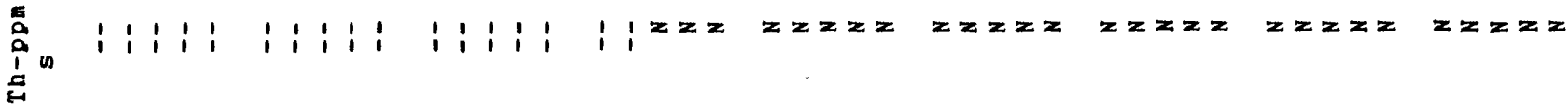

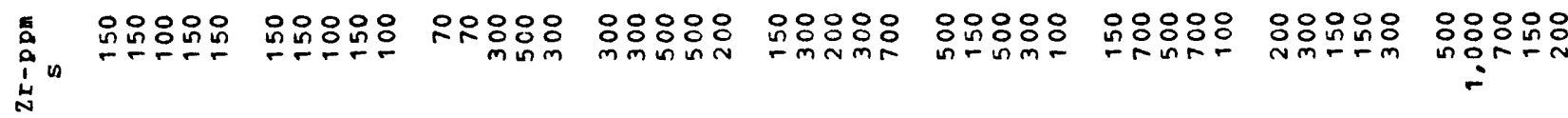

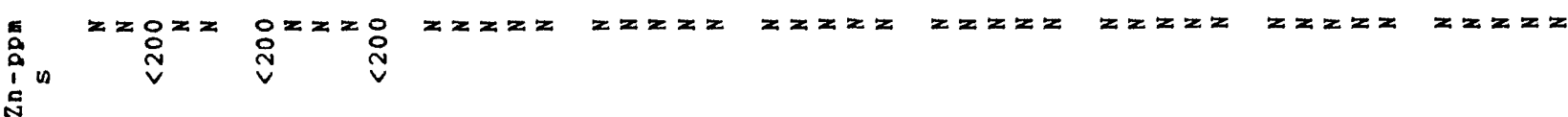

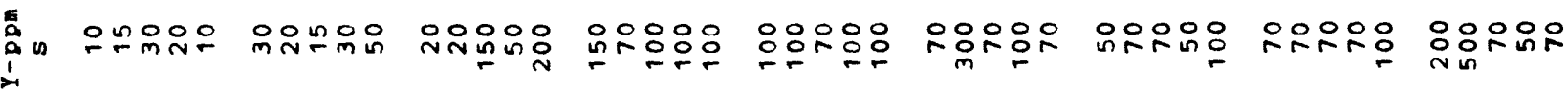

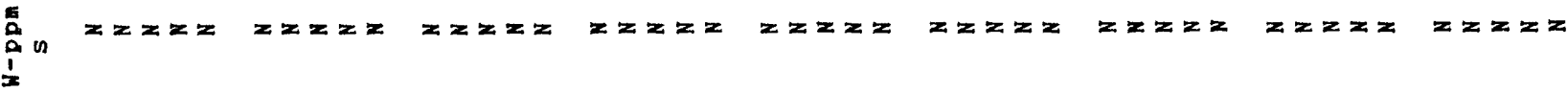

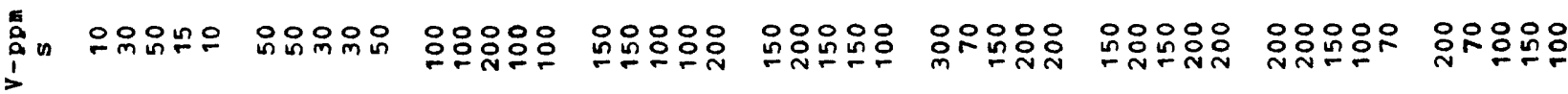

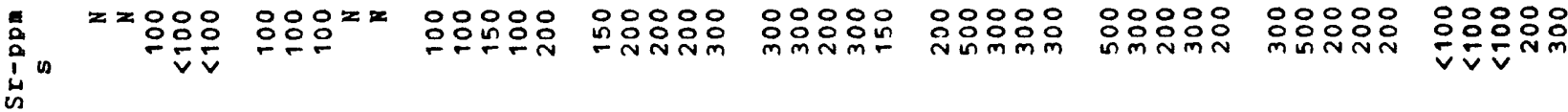

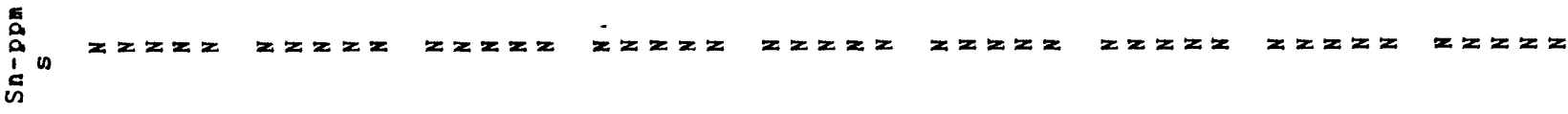

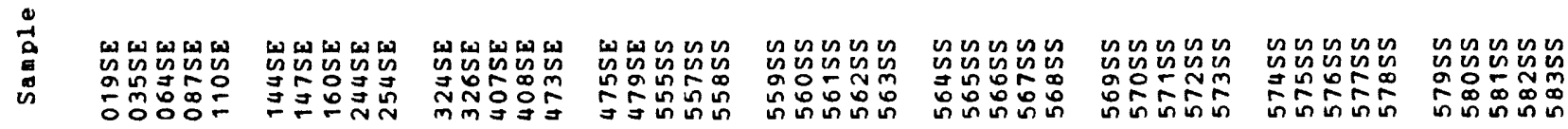


a

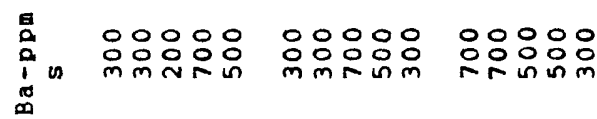

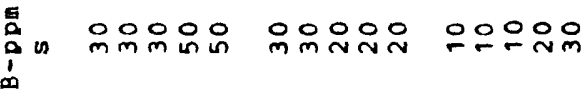

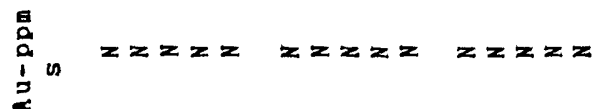

臬 $z z z z z \quad z z z z z \quad z z z z z$

is

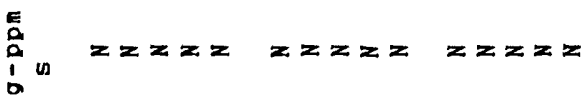

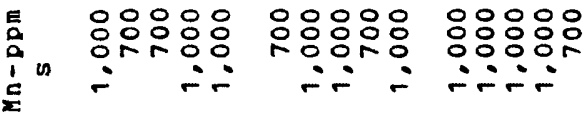

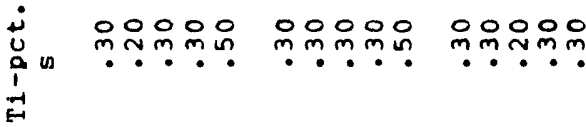

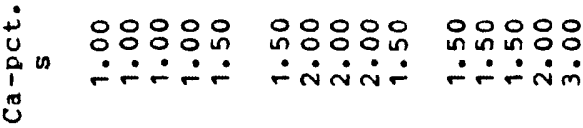

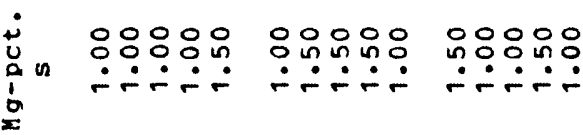

i 000000000000000

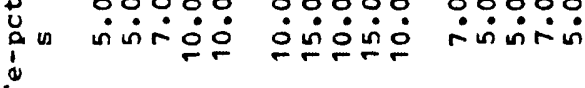

is

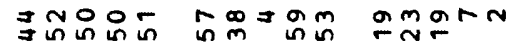

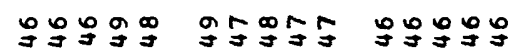

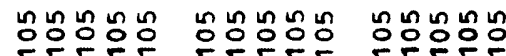

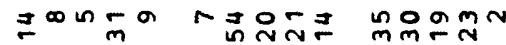

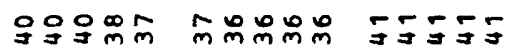

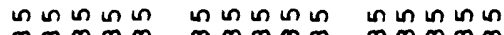

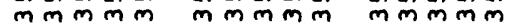

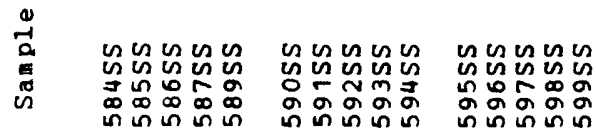




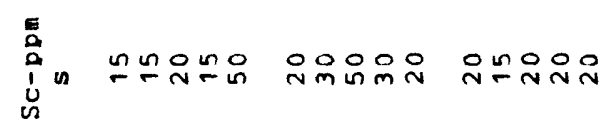

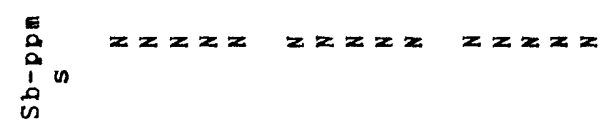

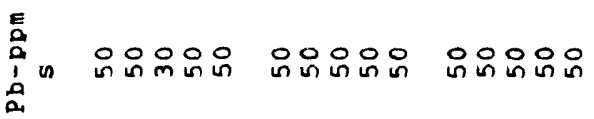

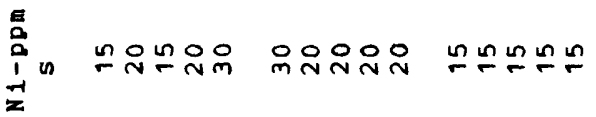

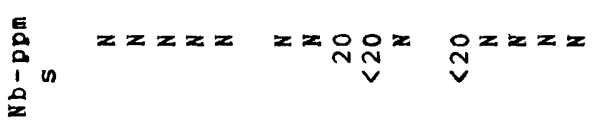

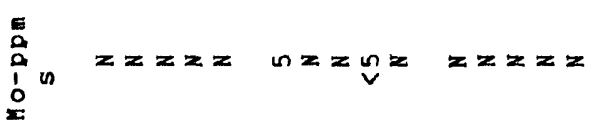

焉

so

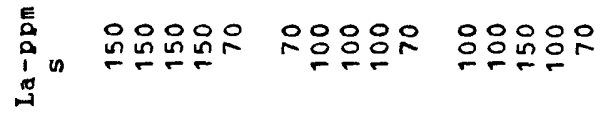

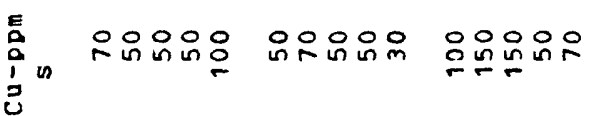

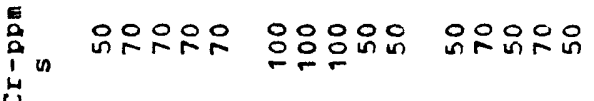

$\breve{u}$

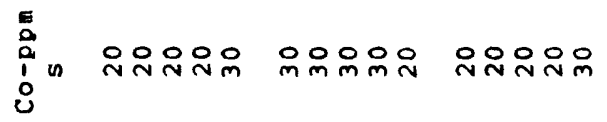

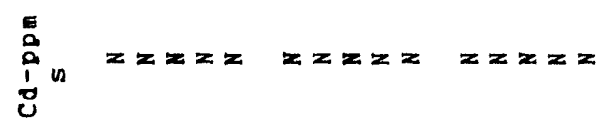

บ

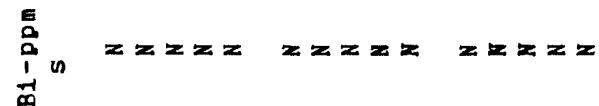

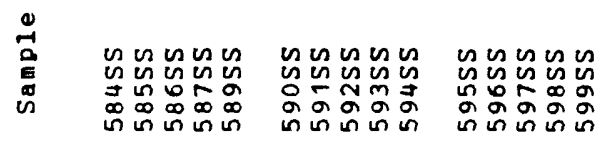




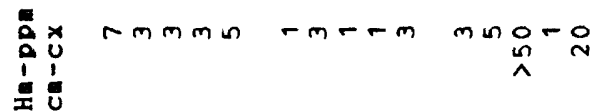

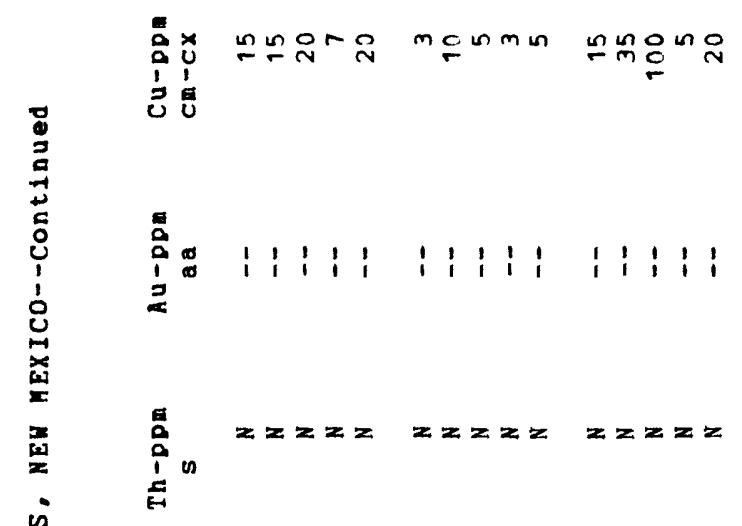

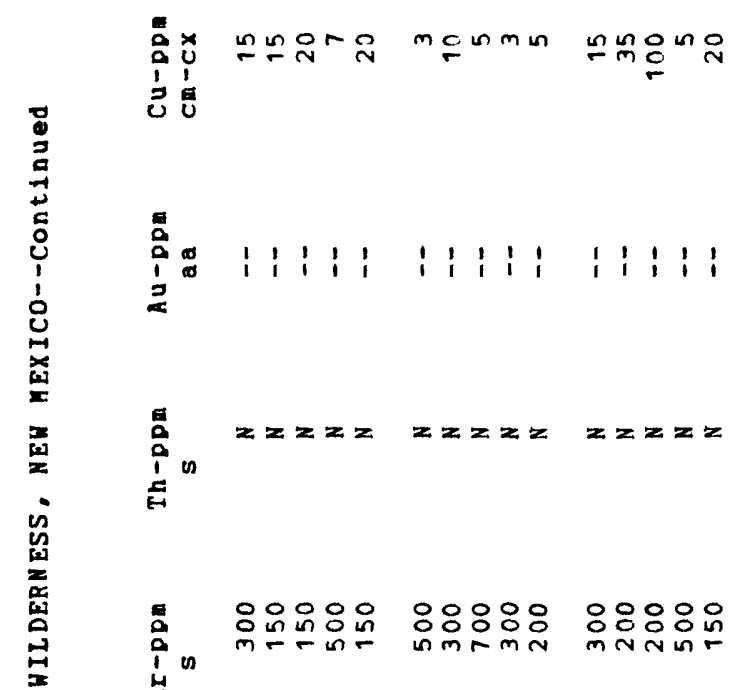

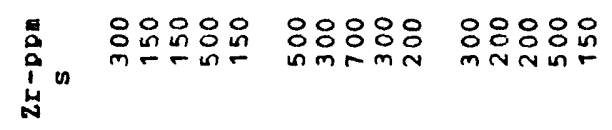

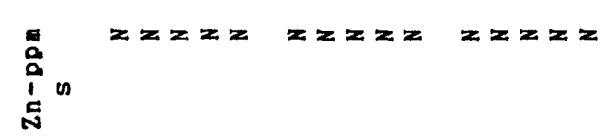

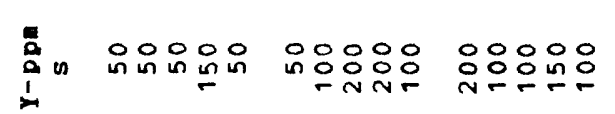

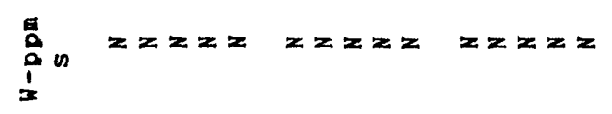

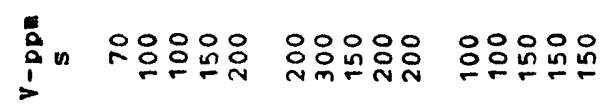

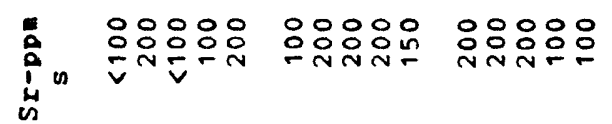

$\dot{0}$

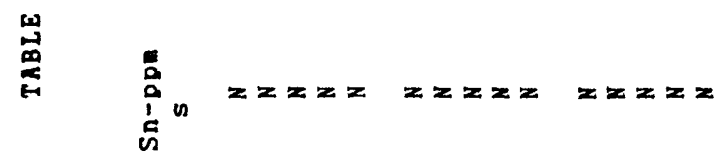

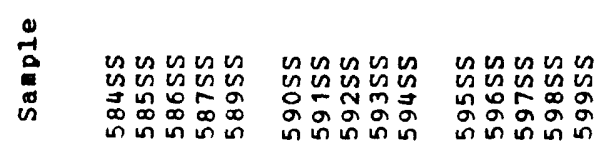




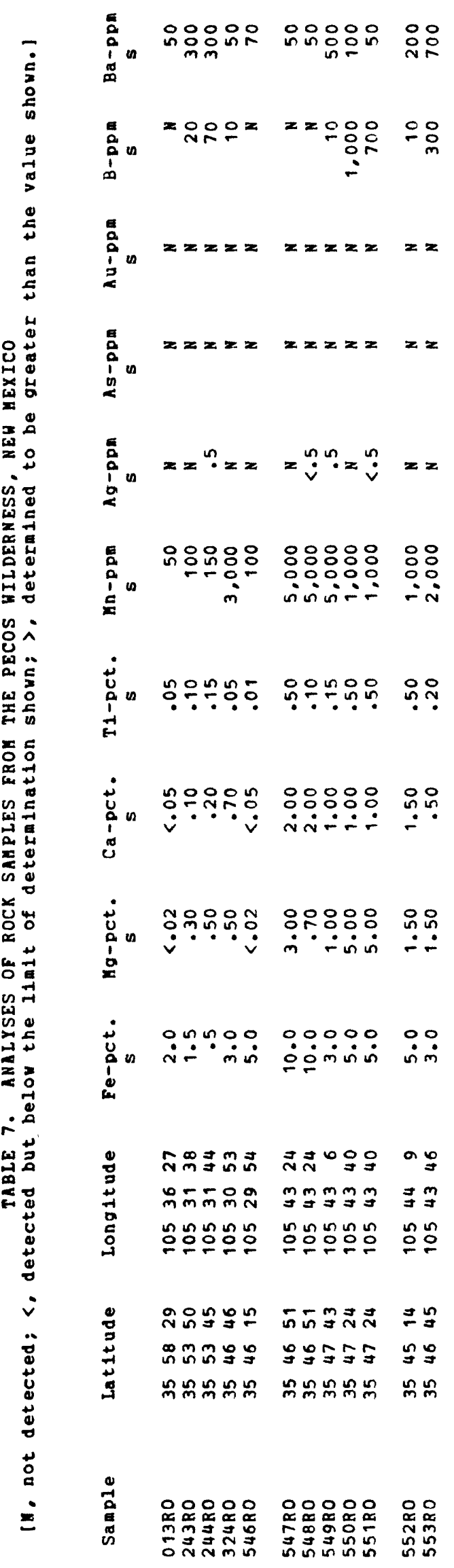




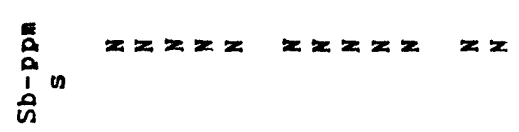

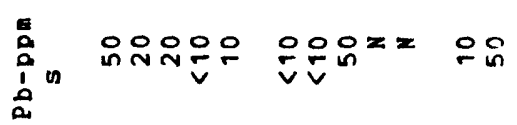

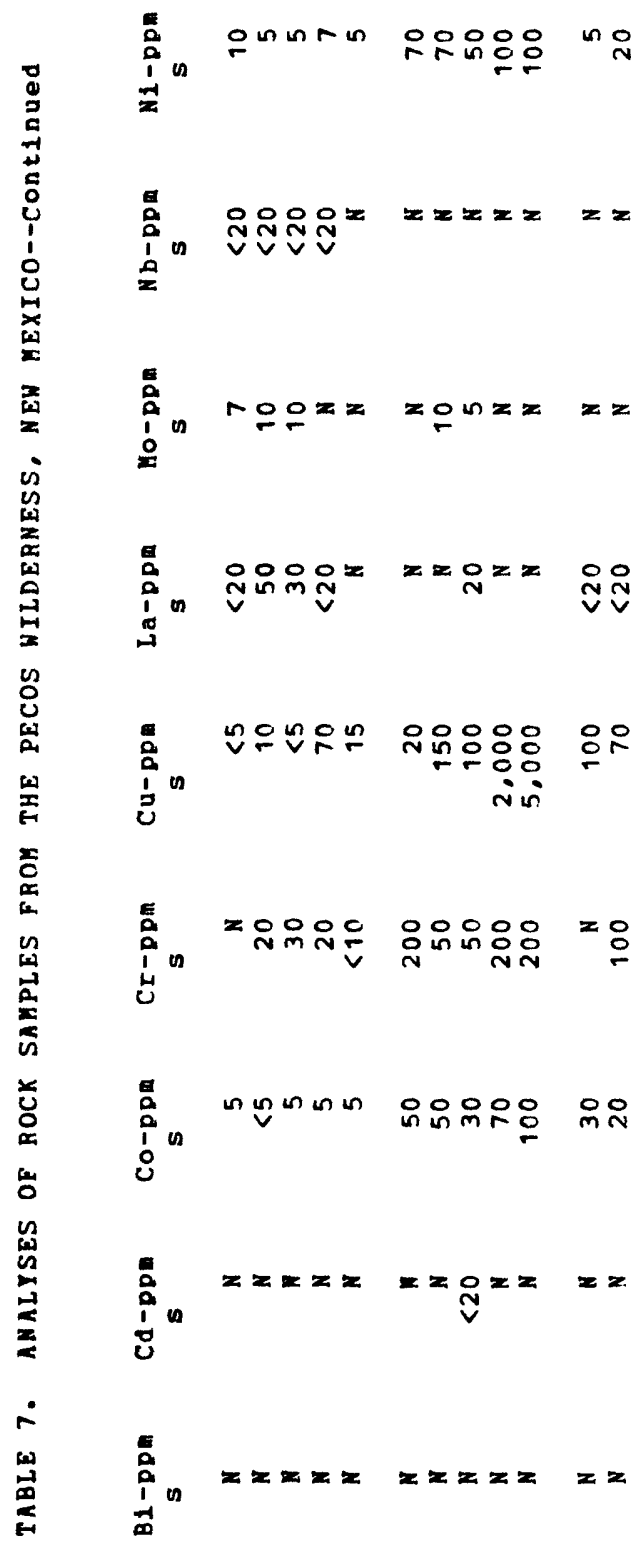

总

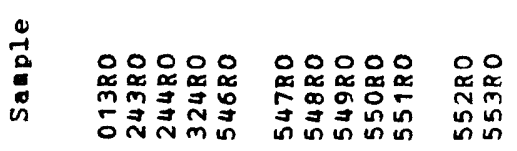




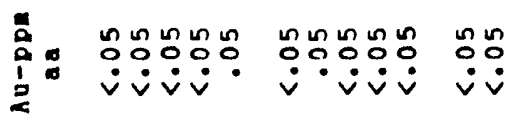

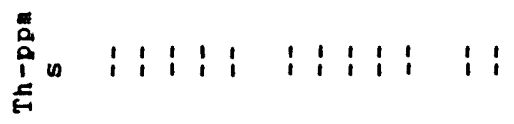

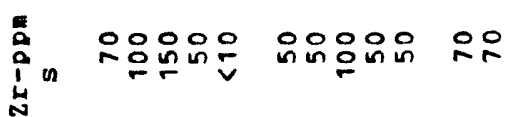

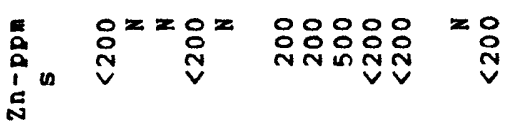

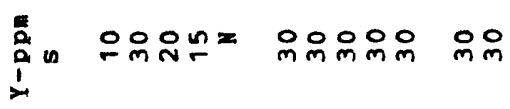

总

zo

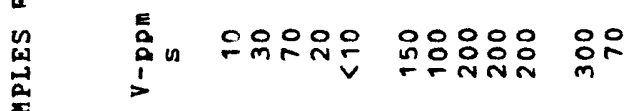

ธs

边

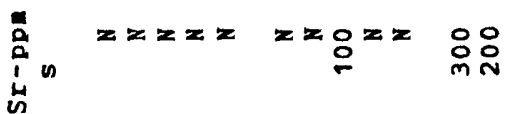

瓷

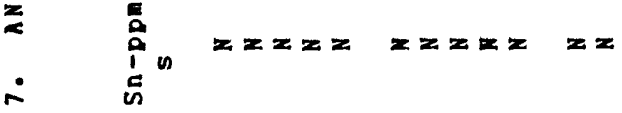

崫

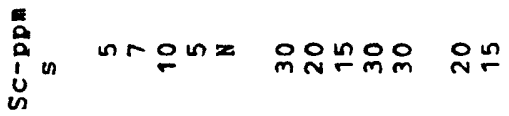

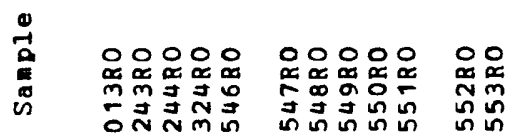




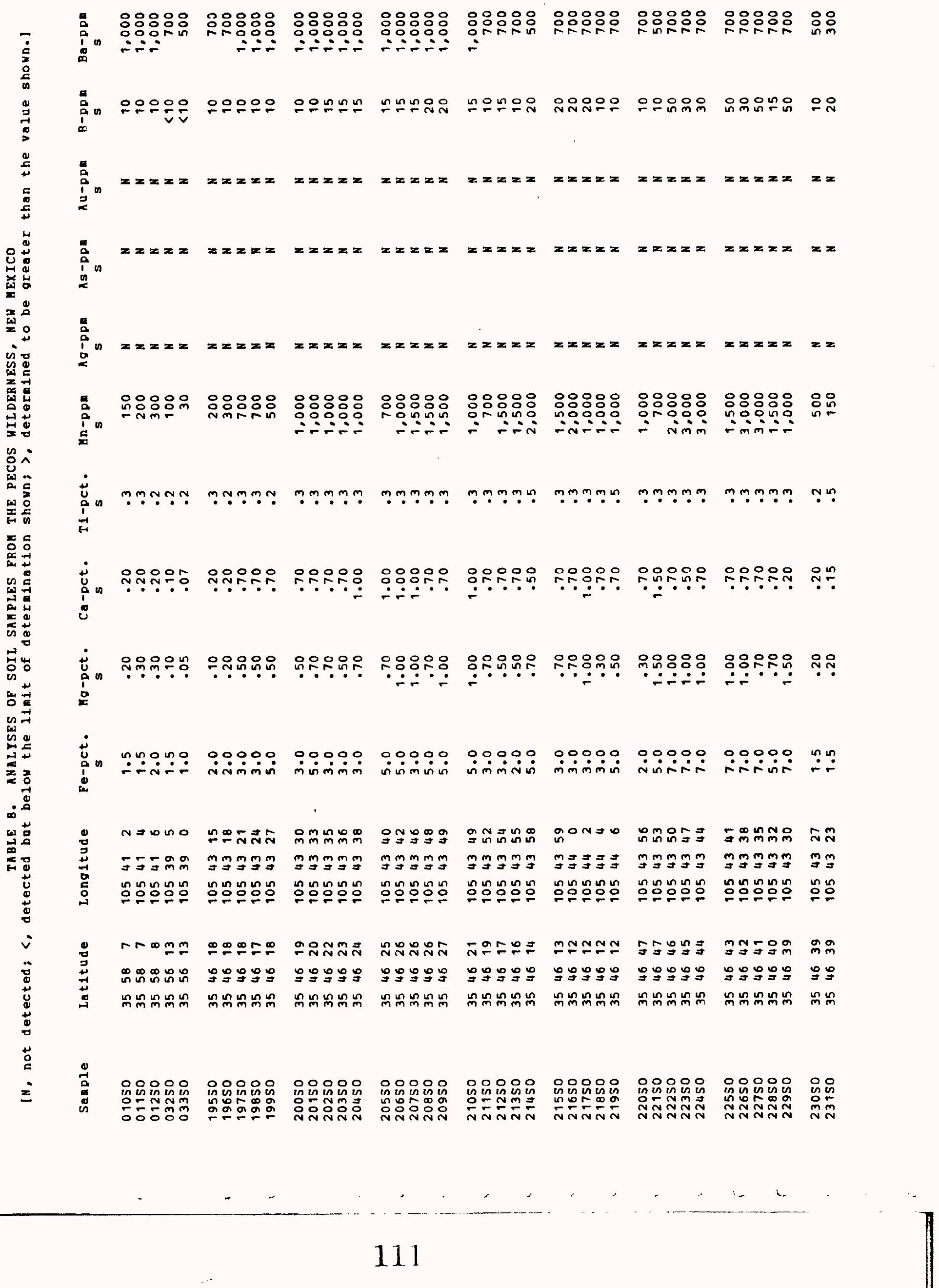




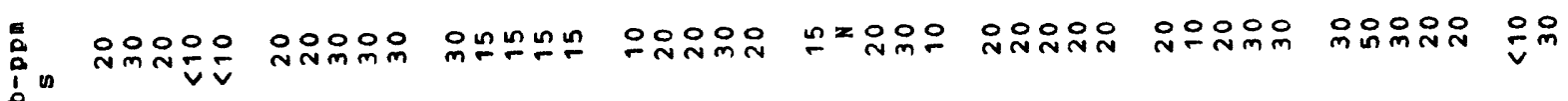
a

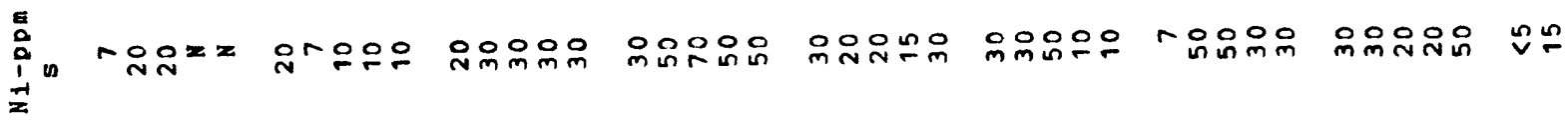

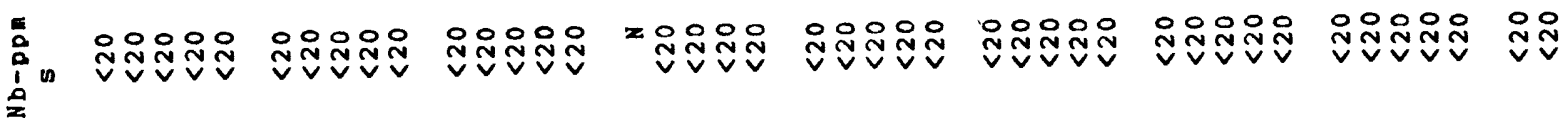

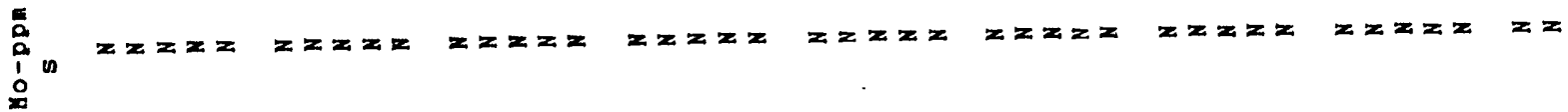

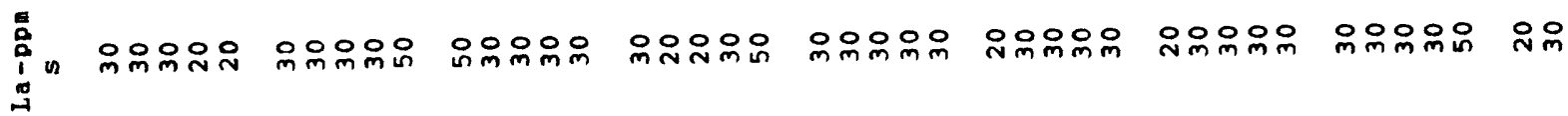

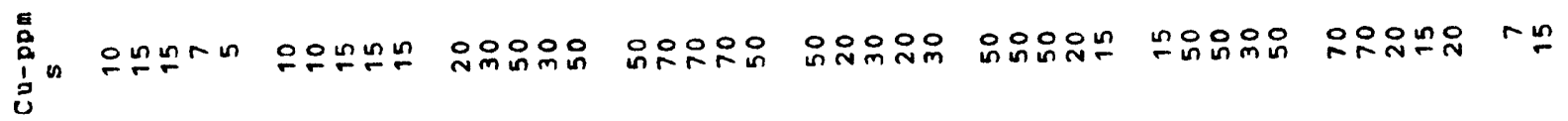

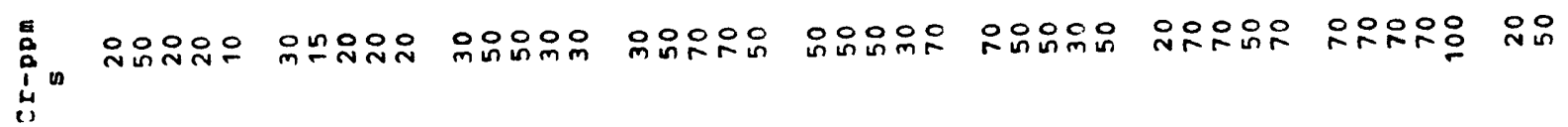
ํㅕㅇำ

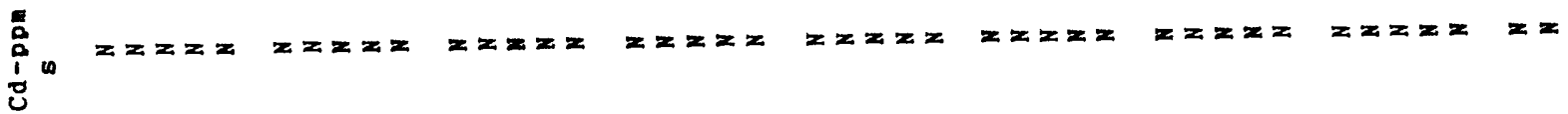

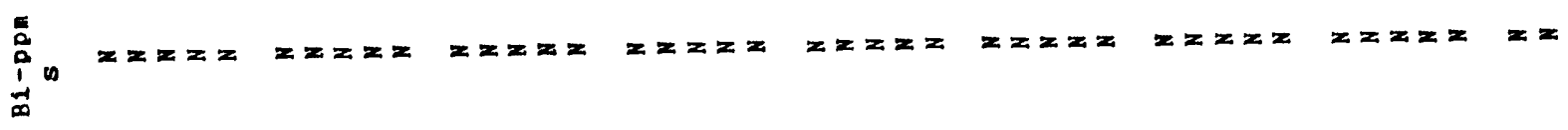
息山

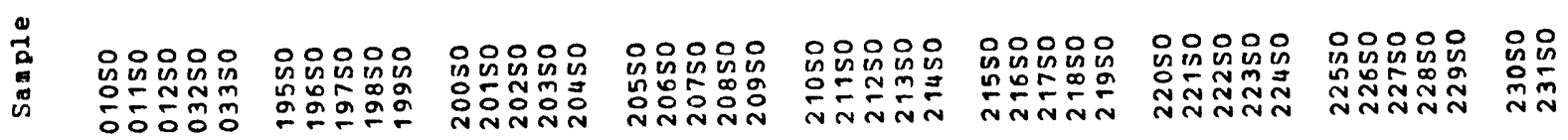




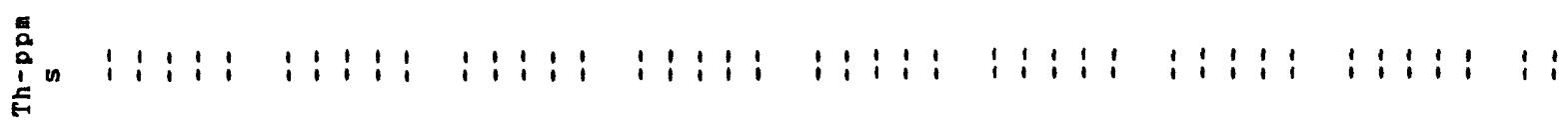
望

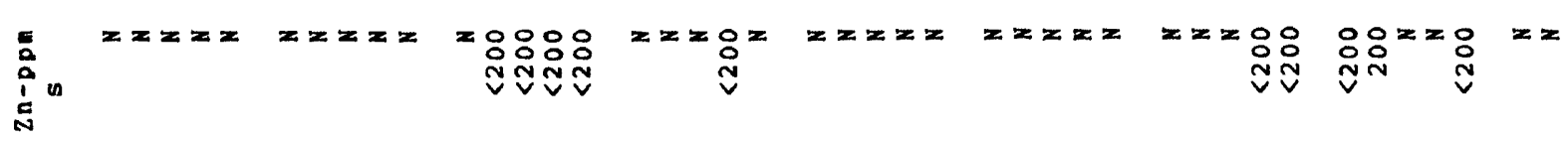

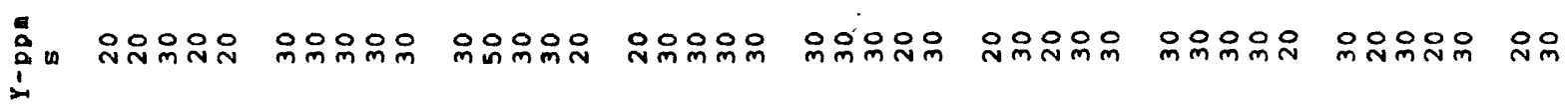

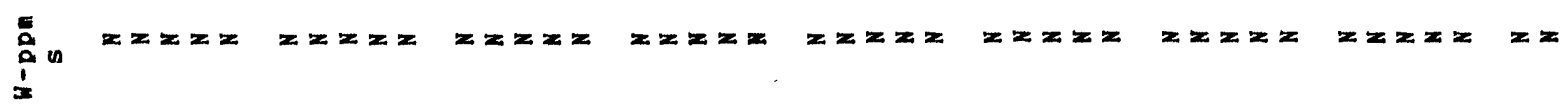

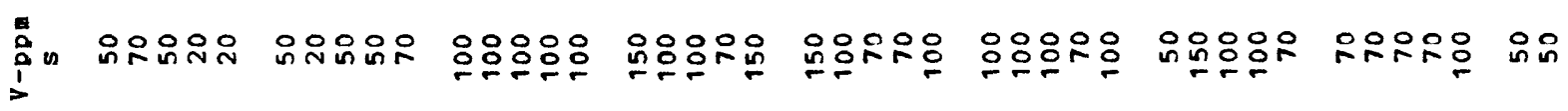

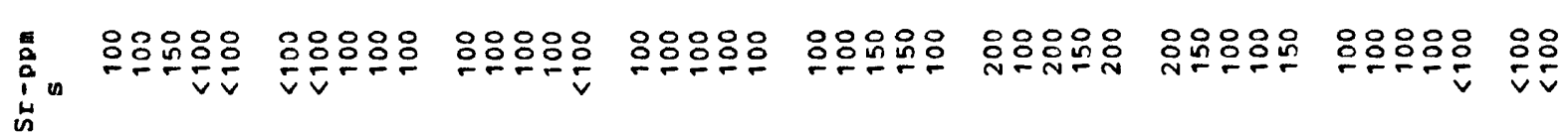
is

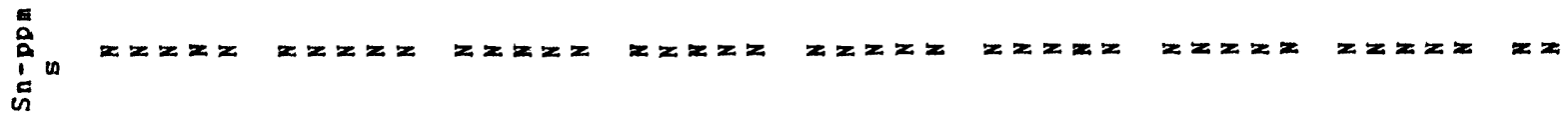

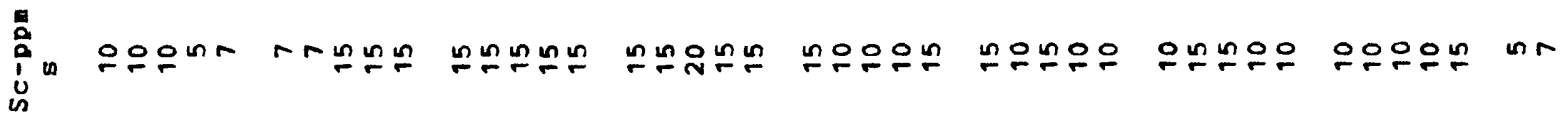
$\underset{\substack{\text { 至 } \\ \text { 点 }}}{\infty}$

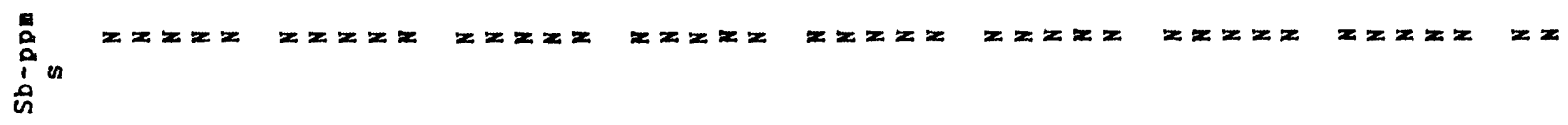

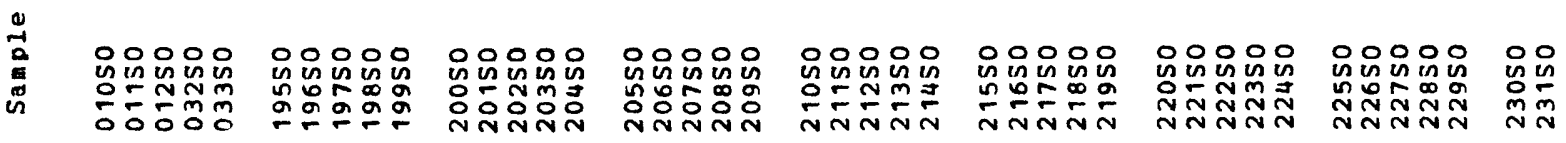

